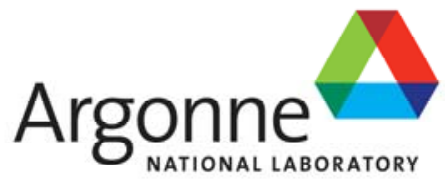

ANL-12/56

\title{
Crack Growth Rate and Fracture Toughness Tests on Irradiated Cast Stainless Steels
}

Nuclear Engineering Division 
About Argonne National Laboratory

Argonne is a U.S. Department of Energy laboratory managed by UChicago Argonne, LLC under contract DE-AC02-06 CH11357. The Laboratory's main facility is outside Chicago, at 9700 South Cass Avenue, Argonne, Illinois 60439. For information about Argonne and its pioneering science and technology programs, see www.anl.gov.

\section{Availability of This Report}

This report is available, at no cost, at http://www.osti.gov/bridge. It is also available

on paper to the U.S. Department of Energy and its contractors, for a processing fee, from:

U.S. Department of Energy

Office of Scientific and Technical Information

P.O. Box 62

Oak Ridge, TN 37831-0062

phone (865) 576-8401

fax (865) 576-5728

reports@adonis.osti.gov

This report was prepared as an account of work sponsored by an agency of the United States Government. Neither the United States Government nor any agency thereof, nor UChicago Argonne, LLC, nor any of their employees or officers, makes any warranty, express or implied, or assumes any legal liability or responsibility for the accuracy, completeness, or usefulness of any information, apparatus, product, or process disclosed, or represents that its use would not infringe privately owned rights. Reference herein to any specific commercial product, process, or service by trade name, trademark, manufacturer, or otherwise, does not necessarily constitute or imply its endorsement, recommendation, or favoring by the United States Government or any agency thereof. The views and opinions of document authors expressed herein do not necessarily state or reflect those of the United States Government or any agency thereof, Argonne National Laboratory, or UChicago Argonne, LLC. 


\section{Crack Growth Rate and Fracture Toughness Tests on Irradiated Cast Stainless Steels}

Y. Chen, B. Alexandreanu, and K. Natesan

Nuclear Engineering Division

Argonne National Laboratory

A. S. Rao, NRC Project Manager

November 2012 
This page is intentionally left blank. 


\begin{abstract}
Cast austenitic stainless steels are used in the cooling system of light water reactors for components with complex shapes, such as pump casings, valve bodies, and coolant piping. In the present study, crack growth rate and fracture toughness JR curve tests were performed on irradiated cast stainless steels in low-corrosion-potential environments (low-dissolved-oxygen high-purity water or simulated pressurized water reactor environment) at $320^{\circ} \mathrm{C}$. Both asreceived and thermally aged materials were included to investigate the combined effect of thermal aging and irradiation embrittlement on the fracture behavior of cast stainless steels. The samples were irradiated to approximately $0.08 \mathrm{dpa}$ at the Halden reactor. Good resistance to corrosion fatigue and stress corrosion cracking was observed for all samples. Thermal aging had little effect on the crack growth behavior at this dose level. Cleavage-like fracture was the dominant cracking morphology during the crack growth rate tests, and the ferrite phase was deformed to a lesser extent compared with the surrounding austenite phase. The fracture toughness results showed a dominant effect of neutron irradiation, and the fracture resistances were decreased considerably for all cast specimens regardless of their thermal aging conditions. The reduction in fracture toughness was more significant in the unaged than thermally aged materials. Nonetheless, the fracture toughness values of thermally aged specimens were about $30 \%$ lower than their unaged counterparts, suggesting a combined effect of thermal aging and neutron irradiation in cast stainless steel.
\end{abstract}


This page is intentionally left blank. 


\section{Contents}

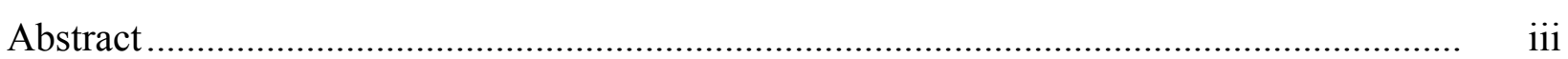

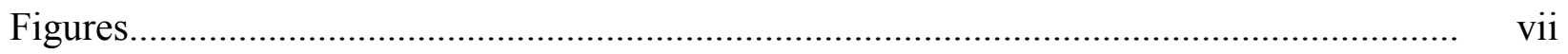

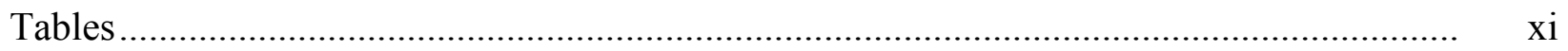

Executive Summary ............................................................................................. xii

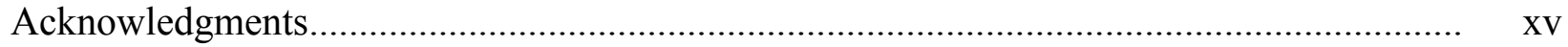

Acronyms and Abbreviations ……….................................................................... xvii

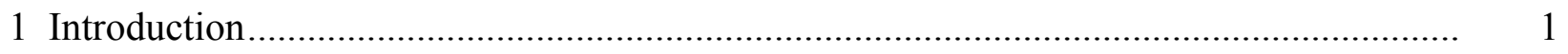

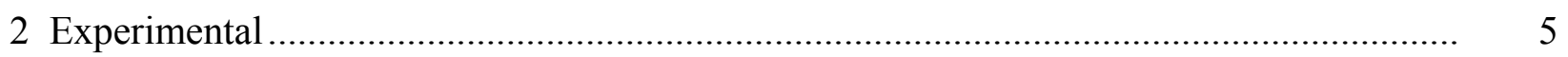

2.1 Materials and Specimens ..................................................................................... 5

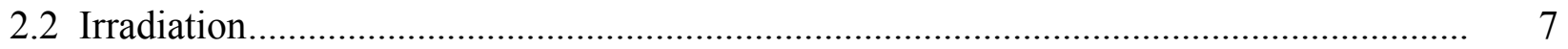

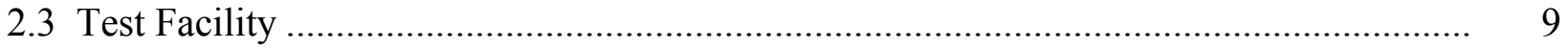

2.4 Crack Growth Rate and Fracture Toughness JR Curve Tests........................................... 10

2.4.1 Crack Growth Rate Test...................................................................................... 10

2.4.2 Fracture Toughness JR Curve Test ...................................................................... 12

2.4.3 Fractographic Examination................................................................................. 14

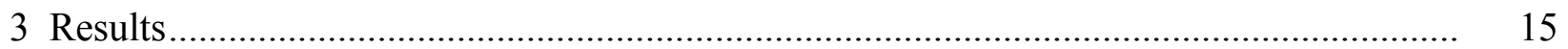

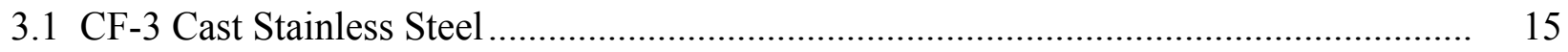

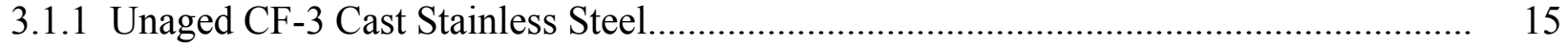

3.1.2 Thermally Aged CF-3 SS................................................................................ 32

3.2 CF-8 Stainless Steel ....................................................................................... 42

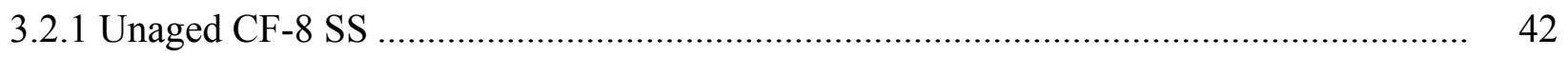

3.2.2 Thermally Aged CF-8 SS.................................................................................. 52

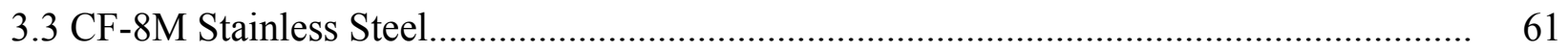

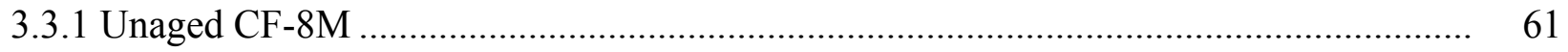

3.3.2 Thermally Aged CF-8M CASS ………............................................................. 71

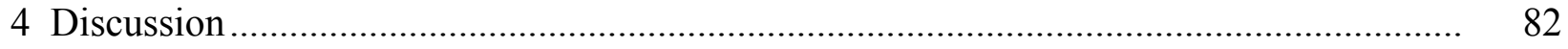

4.1 Cyclic Crack Growth Rates ................................................................................... 83

4.2 Constant-load Crack Growth Rates ....................................................................... 87

4.3 Fracture Toughness ........................................................................................... 88

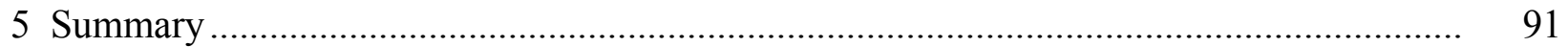

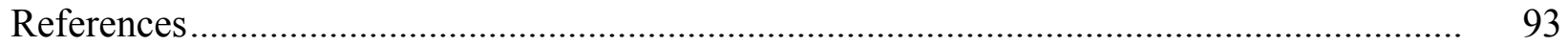


This page is intentionally left blank. 


\section{Figures}

1. Metallurgical images of the unaged and thermally aged CASS materials

2. Schematic of $1 / 4 \mathrm{~T}-\mathrm{CT}$ specimen used in this study (red lines represent electrical leads).

3. Irradiation capsule of low-dose Halden irradiation.

4. Recirculation water loop for Cell 1 of the IML (items in red are safety significant components)

5. Schematic for inducing environmentally assisted cracking in test environment.

6. Crack-length-vs.-time plot for specimen A-1 (0.08-dpa unaged CF-3 with $24 \%$ ferrite): test periods (a) a-e, (b) f-j, (c) k-m, and (d) 1

7. Cyclic CGRs of Specimen A-1.

8. Fracture surface of specimen A-1 tested in PWR water.

9. Fracture surface of specimen A-1 along the sample central line.

10. Cleavage fracture in specimen A-1: (a) pre-cracking, and (b) end of the CGR test. Crack propagation from bottom to top.

11. Fracture surface of specimen A-1 showing that delta ferrite deformed to a lesser extent than austenite. Crack propagation from bottom to top.

12. Crack-length-vs.-time plot for specimen A-2 (0.08-dpa unaged CF-3 with $24 \%$ ferrite) tested in low-DO high-purity water environment: test periods (a) a-e, (b) f-j, (c) k-o, (d) p-s, and (e) 1-2.

13. Cyclic CGRs of Specimen A-2.

14. The J-R curve for specimen A-2 ..................................................................... 28

15. Fracture surface of Specimen A-2 tested in low-DO high-purity water...................... . 29

16. Fracture surface of specimen A-2 along the sample central line................................. 30

17. Cleavage steps at the beginning of CGR test of Specimen A-2. Crack propagation from bottom to top.

18. Fracture surface of specimen A-2 showing that ferrite deformed to a lesser extent than austenite. Crack propagation from bottom to top.

19. Ductile dimple morphology in the JR test region of specimen A-2. Crack propagation from bottom to top.

20. Crack-length-vs.-time plot for specimen B-1 (0.08-dpa aged CF-3 with 24\% ferrite) in PWR water: test periods (a) a-e, (b) f-k, (c) l-t, (d) v-y, (e) z-ac, (f) ad-ag, (h) ah-al, and $(\mathrm{g})$ am- 1 .

21. Cyclic CGRs of specimen B-1.

22. SCC CGRs of unaged and thermally aged CF-3 with $24 \%$ ferrite irradiated to 0.08 dpa. 
23. The J-R curve for specimen B-1_....................................................................... 38

24. Fracture surface of specimen B-1 tested in PWR water. ………………………......... . 39

25. Fracture surface of Specimen B-1 along the sample central line.................................. 40

26. Cleavage steps in the pre-cracking region of specimen B-1. Crack propagation from bottom to top.

27. Delta ferrite at dendrite cores in specimen B-1. Crack propagation from bottom to top.

28. Fracture surface of specimen B-1 showing that delta ferrite is surrounded by heavily deformed austenite phase. Crack propagation from bottom to top.

29. Crack-length-vs.-time plot for specimen E-1 (0.08-dpa unaged CF-8 with $23 \%$ ferrite): test periods (a) a-d, (b) e-f, (c) g-j, (d) k-o, and (e) p-2.

30. Cyclic CGRs of Specimen E-1 ...............................................................................

31. The JR curve of specimen E-1 ........................................................................ 47

32. Fracture surface of specimen E-1 tested in low-DO high-purity water.......................... . 48

33. Fracture surface of specimen E-1 along the sample central line. ................................... 49

34. Cleavage cracking at the beginning of the CGR test of specimen E-1. Crack propagation from bottom to top............................................................................. 50

35. Cyclic CGR test region of specimen E-1. Crack propagation from bottom to top........ 50

36. Smooth fracture surface at the end of the CGR test in specimen E-1. Crack propagation from bottom to top

37. Ductile dimple fracture in the J-R test region of specimen E-1. Crack propagation from bottom to top.

38. Crack-length-vs.-time plot for specimen F-1 (0.08-dpa aged CF-8 with 23\% ferrite): test periods (a) a-f, (b) g-j, (c) k-m, and (d) 1 .

39. Cyclic CGRs of Specimen F-1 ..............................................................................

40. SCC CGRs of unaged and aged CF-8 CASS with $23 \%$ ferrite irradiated to $0.08 \mathrm{dpa}$... 55

41. The J-R curve of specimen F-1..........................................................................

42. Fracture surface of specimen F-1 tested in low-DO high-purity water. ........................ . 57

43. Fracture surface of specimen F-1 along the sample central line.................................... 58

44. Fracture surface of the CGR region in specimen F-1. Crack propagation from bottom to top.

45. Cleavage steps in austenite grain around ferrite phase in the CGR test region of specimen F-1. Crack propagation from bottom to top.

46. Dimple fracture in the JR test region of specimen F-1. Crack propagation from bottom to top. 
47. Crack-length-vs.-time plot for specimen I-1 (0.08-dpa unaged CF-8M with $28 \%$ ferrite): test periods (a) a-f, (b) g-k, (c) l-o, (d) q-r, (e) s-v, (f) w-z, (g) aa-ac, and (h) 1.63

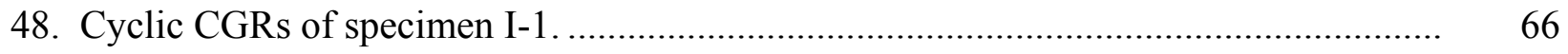

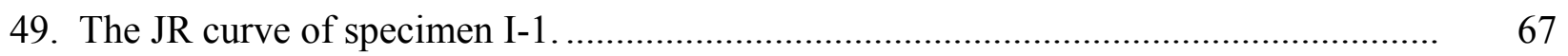

50. Fracture surface of specimen I-1 tested in low-DO high-purity water........................ . 68

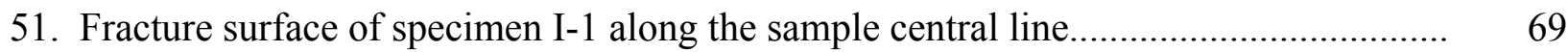

52. Precracking region in the CGR test of specimen I-1. Crack propagation from bottom to top.

53. Fracture surface at the end of CGR test of specimen I-1. Crack propagation from bottom to top.

54. Heavily deformed microstructure in the JR test region of specimen I-1....

55. Crack-length-vs.-time plot for specimen J-1 (0.08-dpa aged CF-8M with 28\% ferrite): test periods (a) a-g, (b) h-n, (c) o-r, (d) s-u, (e) 1, and (f) 2 .

56. Cyclic CGRs of specimen J-1.

57. SCC CGRs of unaged and aged CF-8M CASS, irradiated to $0.08 \mathrm{dpa}$........................ 75

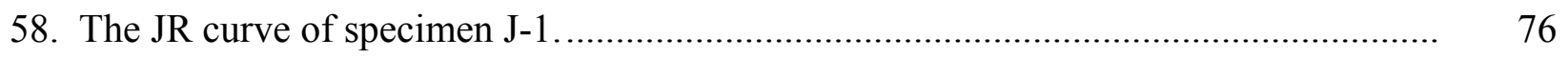

59. Fracture surface of specimen J-1 tested in low-DO high-purity water........................ . 78

60. Fracture surface of specimen J-1 along the sample central line. .................................. 79

61. Precracking region of specimen J-1. Crack propagation from bottom to top.............. 80

62. Ferrite microstructure at the end of CGR test of specimen J-1. Crack propagation from bottom to top.

63. Cleavage fracture at the end of CGR test of specimen J-1. Crack propagation from bottom to top.

64. Fracture along ferrite at dendrite core in the JR test region of specimen J-1. Crack propagation from bottom to top.

65. Best-fit curves of cyclic CGRs at 0.08-dpa dose: (a) unaged and aged CF-3, (b) unaged and aged CF-8, and (c) unaged and aged CF-8M.

66. Fitting coefficient $\mathrm{A}$ for the corrosion fatigue superposition model.

67. Constant-load CGRs of the low-dose CASS with more than $23 \%$ ferrite in low-DO high-purity and PWR water environments.

68. Fracture toughness values of unirradiated and irradiated CASS in unaged and aged conditions. (Note that the unirradiated results are from $1 \mathrm{~T}-\mathrm{CT}$ specimens at $290^{\circ} \mathrm{C}$ in an air atmosphere, and the irradiated results are from $1 / 4 \mathrm{~T}-\mathrm{CT}$ specimens at $320^{\circ} \mathrm{C}$ in water environments.) 
This page is intentionally left blank. 
1. Chemical compositions of the cast stainless steels examined in this study....................... 5

2. Thermal aging conditions for the cast stainless steels in this study................................... 5

3. Test matrix of low-dose CASS specimens irradiated at the Halden reactor........................ 15

4. Crack growth rates of specimen A-1 (0.08-dpa unaged CF-3 sample with $24 \%$ $\delta$ ferrite) in PWR water.

5. Crack growth rates of specimen A-2 (0.08-dpa unaged CF-3 with $24 \% \delta$ ferrite) in low-DO high-purity water environment.

6. CGR test of specimen B-1 (0.08-dpa aged CF-3 with $24 \% \delta$ ferrite) in PWR water

7. CGR test of specimen E-1 (0.08-dpa unaged CF-8 with $23 \% \delta$ ferrite) in low-DO high-purity water.

8. Crack growth rates of specimen F-1 (0.08-dpa aged CF- 8 with $23 \% \delta$ ferrite) in a low-DO high-purity water environment.

9. Crack growth rates of specimen I-1 (0.08-dpa unaged CF-8M with $28 \% \delta$ ferrite) in a low-DO high-purity water environment.

10. Crack growth rates of specimen J-1 (0.08-dpa aged CF-8M with $28 \% \delta$ ferrite) in a low-DO high-purity water environment.

11. CGR and JR curve test results at $320^{\circ} \mathrm{C}$ for 0.08 -dpa CASS specimens with high ferrite contents $(>23 \%)$ 
This page is intentionally left blank. 


\section{Executive Summary}

Cast austenitic stainless steel (CASS) is used in the cooling system of light water reactors for components with complex shapes, such as pump casings, valve bodies, coolant piping, control rod guide tube spacers, etc. In contrast to a fully austenitic microstructure of wrought stainless steel (SS), CASS consists of a ferrite-austenite duplex microstructure. A certain amount of delta ferrite phase is intentionally designed into CASS and SS weld metals to engineer against hot cracking. However, the ferrite phase is vulnerable to thermal aging embrittlement after longterm exposure to reactor coolant. In addition, neutron irradiation can decrease the fracture resistance of CASS significantly. It is suspected that a combined effect of thermal aging and irradiation embrittlement could reduce the fracture resistance even further to a level neither of these degradation mechanisms can impart alone. While the thermal aging embrittlement of CASS has been studied extensively, there are no data available at present with regard to the combined effect of thermal aging and irradiation embrittlement. A test program has been initiated to investigate the joint effect of thermal aging and irradiation damage on the cracking susceptibility and fracture resistance of CASS.

Crack growth rate (CGR) and fracture toughness JR curve tests were conducted on three grades of CASS (CF-3, CF-8 and CF-8M) containing high levels of delta ferrite $(>23 \%)$. These samples were irradiated at the Halden reactor to a low dose of 0.08 displacements per atom (dpa) or $5.56 \times 10^{19} \mathrm{n} / \mathrm{cm}^{2}(\mathrm{E}>1 \mathrm{MeV})$. Both as-received and thermally aged specimens were included to determine the combined effect of thermal aging and irradiation embrittlement. The CGR tests were conducted in a low dissolved oxygen (DO) high purity water environment or a pressurized water reactor $(\mathrm{PWR})$ environment at $320^{\circ} \mathrm{C}$. Following the CGR tests, the fracture toughness JR curve tests were performed on the same samples in the test environments.

Cyclic CGRs and constant-load CGRs were measured to evaluate the corrosion fatigue and stress corrosion cracking (SCC) of the CASS specimens. In the cyclic CGR tests, environmental enhanced cracking was more difficult to establish in these CASS specimens than in wrought SSs. In SCC CGR tests, only moderate CGRs, in the range of $10^{-11} \mathrm{~m} / \mathrm{s}$, were recorded in the CASS specimens regardless of their thermal aging history. In general, the CASS materials showed good resistance to both corrosion fatigue and SCC at the 0.08 dpa dose level. Transgranular cleavage-like cracking was the dominant fracture mode during the CGR tests, and the ferrite phase was often deformed to a less extent compared with its surrounding austenite phase. This observation supports the hypothesis that the beneficial effect of ferrite for SCC resistance arises in part from the high plastic deformation stress of ferrite phase.

A previous study showed that the CGRs of thermally aged CASS were one order of magnitude higher than that of unaged materials at high DO concentrations ( $>1 \mathrm{ppm})$. In contrast, a similar cracking behavior between thermally aged and unaged materials was observed for irradiated specimens in the low-DO high-purity water and simulated PWR environments. The lack of sensitivity to thermal aging history in irradiated samples could be a result of low-corrosionpotential environments employed in this study. It is also possible that an accelerated degradation had taken placed in the unaged CASS during irradiation. At the current dose level, deteriorated cracking properties were developed more efficiently in the unaged than in the thermally aged specimens, resulting in a similar post-irradiation cracking behavior. 
Neutron irradiation significantly affected on the fracture toughness of CASS. At 0.08 dpa, the fracture toughness values of unaged specimens were about one third of their initial unirradiated values. An additional 30\% reduction in fracture toughness was also observed for thermally aged specimens after irradiation. This observation suggests an interaction between thermal aging and irradiation damage. When both conditions of thermal aging and irradiation damage are present, the combined effect is not a simple addition of both degradations. The interaction between thermal aging and irradiation damage can lead to different damage on CASS materials, reducing the fracture resistance to a higher extent than either one of them can achieve alone. Neutron irradiation appears to affect not only the kinetics of thermal aging embrittlement, but also the lower bound values of fracture toughness (i.e., the saturation state). For this reason, the effects of neutron irradiation should be considered when the degree of thermal aging embrittlement is being evaluated for CASS components.

The unirradiated CASS results presented in the current report were obtained from 1T-CT specimens tested in air at $290^{\circ} \mathrm{C}$. However, the irradiated CASS results were obtained from 0.25 $\mathrm{T}-\mathrm{CT}$ specimens in low-corrosion-potential environments at $320^{\circ} \mathrm{C}$. To facilitate a more direct comparison, the staff will test unirradiated CF-8 and CF-8M-unaged and aged - using 0.25T$\mathrm{CT}$ specimens in low-corrosion-potential environments at $320^{\circ} \mathrm{C}$. Once these tests are completed, this report will be expanded and published as a NUREG series report. 


\section{Acknowledgments}

The authors would like to thank Drs. O. K. Chopra and W. J. Shack for their invaluable contribution to this project. Our special thank go out to Ms. T. M. Karlsen, OECD Halden Reactor Project, Halden, Norway, for reactor irradiation experiments and sample transfer. L. A. Knoblich, E. E. Gruber, R. Clark, and E. J. Listwan of Argonne, Y. Yang of University of Florida, and J. Pakarinen and Y. Huang of University of Wisconsion-Madison are acknowledged for their contributions to the experimental effort. We are also grateful to Drs. R. Tregoning and W. J. Shack for their careful reviews and comments on the manuscript. This work is sponsored by the Office of Nuclear Regulatory Research, U.S. Nuclear Regulatory Commission, under Job Code N6519; Program Manager: A. S. Rao. 
This page is intentionally left blank. 
ASTM American Society for Testing and Materials

BWR Boiling Water Reactor

CASS Cast Austenitic Stainless Steels

CGR Crack Growth Rate

CT Compact Tension

DCPD Direct Current Potential Drop

DO Dissolved Oxygen

ECP Electrochemical Potential

HWC Hydrogen Water Chemistry

IASCC Irradiation-Assisted Stress Corrosion Cracking

IGSCC Intergranular Stress Corrosion Cracking

IML Irradiated materials Laboratory

LVDT Linear Voltage Displacement Transducer

LWR Light Water Reactor

NWC Normal Water Chemistry

PPU Periodical Partial Unloading

PWR Pressurized Water Reactor

SCC Stress Corrosion Cracking

SEM Scanning Electron Microscopy

SS Stainless Steel 


\section{Units of Measure}

$\begin{array}{ll}{ }^{\circ} \mathrm{C} & \text { degrees centigrade } \\ \mathrm{cm} & \text { centimeter } \\ \mathrm{dpa} & \text { displacement per atom } \\ \mathrm{hr} & \text { hour } \\ \mathrm{J} & \text { joule } \\ \mathrm{m} & \text { meter } \\ \mathrm{mm} & \text { millimeter } \\ \mathrm{MPa} & \text { megapascal } \\ \mathrm{ppb} & \text { part per billion } \\ \mathrm{ppm} & \text { part per million } \\ \mathrm{psig} & \text { pound per square inch gauge } \\ \mathrm{s} & \text { second } \\ \mu & \text { micron }\end{array}$




\section{Introduction}

Stainless steel is an important class of engineering materials used in light water reactors (LWRs). While the main structure of reactor core internals is constructed from wrought stainless steels (SSs), components with complex shapes, such as pump casings, valve bodies, coolant piping, elbows, and control rod guide tube spacers, are often made of cast austenitic stainless steels (CASS). ${ }^{1}$ The CF grades of CASS whose compositions are similar to those of 300 -series austenitic SSs are the most widely used corrosion-resistant CASS. The CF-3 and CF-8 grades contain nominal $19 \% \mathrm{Cr}$ and $9 \% \mathrm{Ni}$ and are the cast equivalents of Types 304L and $304 \mathrm{SSs}$, respectively. Meanwhile, the $\mathrm{CF}-3 \mathrm{M}$ and $\mathrm{CF}-8 \mathrm{M}$ grades are the molybdenum-containing cast versions of $316 \mathrm{~L}$ and $316 \mathrm{SSs}$, respectively. Like their wrought equivalents, the CF grades of CASS possess excellent corrosion resistance and mechanical properties, ${ }^{2}$ and thus are ideal for LWR applications in aqueous environments. The strength and ductility of CF grades are comparable to those of wrought SSs. At room temperature, the yield and tensile strengths of CF3 and CF-8 grades are greater than $200 \mathrm{MPa}$ and $480 \mathrm{MPa},{ }^{3}$ respectively, similar to those of solution-annealed SSs. A good combination of strength and ductility also gives rise to excellent fracture toughness. Stable tearing occurs in CASS samples well above their yield strength before final fracture. Chopra and Sather ${ }^{4}$ showed that the fracture toughness of CF-3 and CF-8 CASS varies from $\sim 200 \mathrm{~kJ} / \mathrm{m}^{2}$ to over $1000 \mathrm{~kJ} / \mathrm{m}^{2}$ at room temperature; these values are comparable to those of wrought SSs reported by Mills. ${ }^{5}$

In contrast to the fully austenitic microstructure of wrought SSs, CASS consists of a ferriteaustenite duplex microstructure. It is common that a certain amount of $\delta$ ferrite is present along with austenite $(\gamma)$ in the solidification microstructure such as CASS or weld metals. The precise fractions of ferrite and austenite phases depend on the chemical composition and casting thermal history. Experimental methods, such as quantitative metallography and ferromagnetic measurement, can be used to determine the ferrite content in CASS or weld metals. ${ }^{6,7}$ Empirical models have also been developed to predict and control phase content with alloy composition. Based on the phase-stabilizing effects of $\mathrm{Cr}$ and $\mathrm{Ni}$ in $\mathrm{Fe}-\mathrm{Cr}-\mathrm{Ni}$ systems, several constitution diagrams have been established to estimate phase content. $8,9,10$ The contributions of minor alloying elements are incorporated with $\mathrm{Cr}$ and $\mathrm{Ni}$ equivalent numbers and computed with empirical equations. The applicable range of composition, incorporated alloying elements, and weighing factors vary in these models, and thus the predicted phase contents differ among them to some extent. ${ }^{11}$ For steel castings of CF grades, use of the Scheofer diagram, which is a modified version of the Schaeffler diagram ${ }^{8}$, is recommended by the American Society for Testing and Materials (ASTM) for estimating ferrite content. ${ }^{12}$

The ferrite phase is critical for the mechanical properties and corrosion resistance of CASS and weld metals. Since hardening mechanisms by thermal-mechanical treatments cannot be easily implemented in castings, the strength of CASS mainly relies on the ferrite-austenite duplex microstructure. Beck et al. ${ }^{13}$ showed that the tensile and yield strengths of CASS increase with $\delta$ ferrite content up to $40 \%$ at both room and elevated temperatures. The strengthening effect of ferrite phase is attributed to ferrite-austenite boundaries and can be explained with the Hall-Petch model. ${ }^{14}$ Ferrite phase is also crucial for the soundness and weldability of steel castings. A minimum ferrite content is often specified for SS welds to reduce the tendency of hot cracking. In addition, the presence of ferrite phase can improve the resistance to sensitization and stress 
corrosion cracking (SCC). ${ }^{15}$ In susceptible environments, CASS tends to be more resistant to SCC than the same grade of wrought SS. This beneficial effect of ferrite was clearly demonstrated by Hughes et al. ${ }^{16}$ in boiling water reactor (BWR) environments. Using slow strain rate tests, they showed that $\mathrm{CF}-3, \mathrm{CF}-3 \mathrm{~A}$, and CF-8 have an exceptional resistance to intergranular SCC (IGSCC) in high-purity (HP) water containing 6-8 ppm dissolved oxygen (DO).

While the presence of $\delta$ ferrite in CASS is mostly beneficial, ferrite phase can also exert a detrimental effect on the fracture resistance of CASS under certain conditions. Exposed to temperatures of $300-500^{\circ} \mathrm{C}$, ferrite phase is vulnerable to a low-temperature thermal aging phenomenon known as " $475^{\circ} \mathrm{C}$ embrittlement". 17,18 The consequences of the thermal aging embrittlement are an increased tensile strength and reduced ductility. ${ }^{19,20}$ The upper-shelf impact energy is also reduced, and the ductile-to-brittle transition temperature shifts higher. ${ }^{20}$

Because of thermal aging embrittlement, the long-term performance of CASS materials at elevated service temperatures is of concern. The degradation of CASS components resulting from thermal aging embrittlement has been recognized as a potential issue for aging reactors. ${ }^{21}$ Several research programs have been conducted to assess Charpy impact properties and JR resistance curves of thermally aged CASS. ${ }^{22,23}$ It was found that thermal aging at $290-450^{\circ} \mathrm{C}$ up to $30,000 \mathrm{hr}$ leads to a significant deterioration in the fracture properties of CASS. The lower bound of impact energy and fracture toughness $\left(\mathrm{J}_{\mathrm{IC}}\right)$ can be as low as $20 \mathrm{~J} / \mathrm{cm}^{2}$ and $25 \mathrm{~kJ} / \mathrm{m}^{2}$, respectively, at room temperature. The ductile-to-brittle transition temperature of CASS is also shifted to around $0^{\circ} \mathrm{C}$ for the thermally aged CASS. The extent of the thermal aging embrittlement increases with ferrite content and is sensitive to ferrite morphology. ${ }^{22}$

The mechanism of thermal aging of duplex SSs has been studied extensively. ${ }^{17-20,22-28}$ It is widely accepted that embrittlement is caused by the instability of the ferrite phase under thermal aging. The main reasons of the hardening and loss of toughness are (1) the formation of $\mathrm{Cr}-\mathrm{rich}$ $\alpha$ ' phase through spinodal decomposition and (2) the precipitation and growth of carbides and Gphase at ferrite-austenite phase boundaries. Obviously, these microstructural changes are thermally activated and are fundamentally controlled by solid-state diffusion. Therefore, the thermal aging time for a given extent of degradation (e.g., an increase in hardness or decrease in toughness) follows an Arrhenius-type relationship. ${ }^{24}$

Besides thermal aging, neutron irradiation can also affect the microstructural evolution of CASS profoundly. Under fast neutron bombardment, lattice atoms in a crystalline material are displaced from their original sites by cascade damage. An avalanche of lattice displacements gives rise to point defect supersaturation, which does not exist under thermal equilibrium. ${ }^{29,30}$ These point defects evolve at irradiation temperatures to form irradiation defects, giving rise to irradiation hardening and embrittlement. The irradiation embrittlement can generate further degradation in the ferrite phase, leading to an additional loss of fracture toughness. Furthermore, the presence of nonequilibrium point defects in irradiated microstructures can enhance the transportation of solutes in materials by radiation-enhanced diffusion. ${ }^{30}$ The elevated diffusivity under neutron irradiation could certainly affect the kinetics of thermal aging. Thus, a combined 
effect of irradiation embrittlement and thermal aging could not only produce a higher degree of embrittlement, but also affect the rate of degradation development.

While the thermal aging embrittlement of CASS has been studied extensively, very limited data exist in the open literature for neutron-irradiated CASS. $5,31,32$ Two tests conducted on thermally aged and irradiated CF-8M showed a higher degree of embrittlement in the CASS material than wrought SSs. ${ }^{31}$ It is not clear however if the simultaneous exposure to irradiation and thermal aging would reduce the fracture resistance to a lower level than either of the degradation mechanisms can impart alone. If so, the combined effect is not only important for internal components made of CASS, but also for SS weld metals that possess a similar austenite-ferrite duplex microstructure. While weld metals may contain less ferrite phase than that in CASS materials, a minimum ferrite content is usually specified for weld metals to engineer against hot cracking. Thus, weld metals may be subjected to the same type of degradation as CASS. A better understanding of the combined effect of thermal aging and irradiation would also be helpful to address issues concerning weld metals.

In the current study, several CF grades of CASS were irradiated to approximately 0.08 displacements per atom (dpa). Both as-received and thermally aged specimens are included. Fracture toughness JR curve tests were conducted on these samples to assess the extent of embrittlement resulting from neutron irradiation and thermal aging. Additionally, crack growth rate (CGR) tests were carried out prior to the fracture toughness tests in low electrochemical potential (ECP) environments to evaluate their SCC performance. At 0.08 dpa, significant irradiation embrittlement of ferritic materials is anticipated, but little effect either on embrittlement or stress corrosion susceptibility of austenitic materials would be expected. Thus the current work is focused on the effects of thermal aging and irradiation on the ferrite phase. At higher irradiation levels, additional effect would occur due to embrittlement and increased SCC susceptibility of austenitic phase. Since elevated susceptibility to irradiation-assisted stress corrosion cracking (IASCC) is unlikely at this low dose level, the SCC CGR test was short in the present study. Still, the CGR tests could provide corrosion fatigue starter cracks for the subsequent fracture toughness JR curve tests, so that any environmental contribution to the fracture behavior of CASS could be detected. 
This page is intentionally left blank. 


\section{Experimental}

\subsection{Materials and Specimens}

Three experimental heats of corrosion-resistant CASS (CF-3, CF-8, and CF-8M) were obtained from a previous ANL research program. ${ }^{4}$ The CASS heats are static cast slabs with dimensions of $610 \times 610 \times 76 \mathrm{~mm}$. A ferrite scope measurement on these heats showed that the CF-3 and CF-8 heats contained approximately $24 \%$ delta ferrite, and the CF- $8 \mathrm{M}$ heat had $28 \%$ delta ferrite. Table 1 gives the compositions of these materials. Both as-received (or unaged) and thermally aged specimens were prepared from these heats. The thermal aging conditions are given in Table 2. Figure 1 shows metallurgical images of the CASS materials used in this study. The samples were polished with $\mathrm{SiC}$ papers up to 1200 grit. After a final finish with $1 \mu \mathrm{m}$ diamond slurry, the polished surfaces were etched with ferric chloride. Both the unaged and thermally aged microstructures are similar, as shown in Fig. 1. Note that a slight decline in ferrite content was reported for all grades of CASS after thermal aging. ${ }^{4}$ For the aging conditions used in the current study $\left(10,000 \mathrm{hr}\right.$ at $\left.400^{\circ} \mathrm{C}\right)$, the decrease in ferrite content is insignificant. Thus, the average ferrite contents were considered unchanged after thermal aging.

Table 1. Chemical compositions of the cast stainless steels examined in this study.

\begin{tabular}{|c|c|c|c|c|c|c|c|c|c|c|c|}
\hline \multirow{2}{*}{ Cast Grade } & \multirow{2}{*}{$\begin{array}{c}\text { Ferrite } \\
\text { content a }\end{array}$} & \multirow{2}{*}{$\begin{array}{c}\text { Heat } \\
\text { ID. }\end{array}$} & \multicolumn{8}{|c|}{ Composition (wt. \%) } \\
\cline { 5 - 13 } & & Mn & Si & P & S & Mo & Cr & Ni & N & C \\
\hline CF-3 & $24 \%$ & 69 & 0.63 & 1.13 & 0.015 & 0.005 & 0.34 & 20.18 & 8.59 & 0.028 & 0.023 \\
\hline CF-8 & $23 \%$ & 68 & 0.64 & 1.07 & 0.021 & 0.014 & 0.31 & 20.46 & 8.08 & 0.062 & 0.063 \\
\hline CF-8M & $28 \%$ & 75 & 0.53 & 0.67 & 0.022 & 0.012 & 2.58 & 20.86 & 9.12 & 0.052 & 0.065 \\
\hline
\end{tabular}

a. Measured with a ferrite scope, Ref. [4].

Table 2. Thermal aging conditions for the cast stainless steels in this study.

\begin{tabular}{|c|c|c|c|c|}
\hline Cast Grade & Ferrite & Spec. Code & Heat ID. & Thermal aging condition \\
\hline \multirow{2}{*}{$\mathrm{CF}-3$} & \multirow{2}{*}{$24 \%$} & $\mathrm{~A}$ & 69 & Unaged \\
\cline { 3 - 5 } & & $\mathrm{B}$ & 69 & $10,000 \mathrm{hr}$ at $400^{\circ} \mathrm{C}$ \\
\hline \multirow{2}{*}{$\mathrm{CF}-8$} & \multirow{2}{*}{$23 \%$} & $\mathrm{E}$ & 68 & Unaged \\
\cline { 3 - 5 } & & $\mathrm{F}$ & 68 & $10,000 \mathrm{hr}$ at $400^{\circ} \mathrm{C}$ \\
\hline \multirow{2}{*}{$\mathrm{CF}-8 \mathrm{M}$} & \multirow{2}{*}{$28 \%$} & $\mathrm{I}$ & 75 & Unaged \\
\cline { 3 - 5 } & & $\mathrm{J}$ & 75 & $10,000 \mathrm{hr}$ at $400^{\circ} \mathrm{C}$ \\
\hline
\end{tabular}




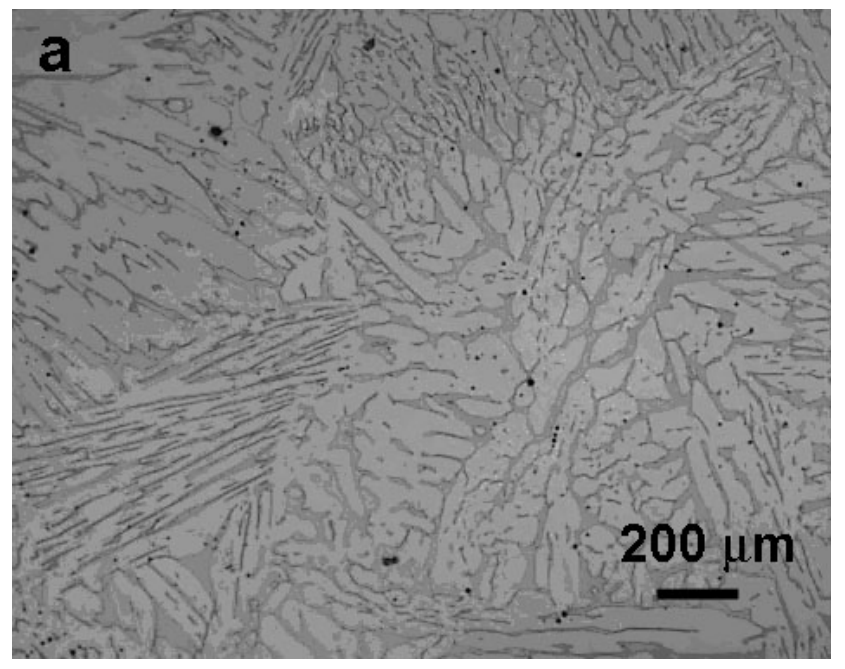

CF-3, 24\% $\delta$, unaged

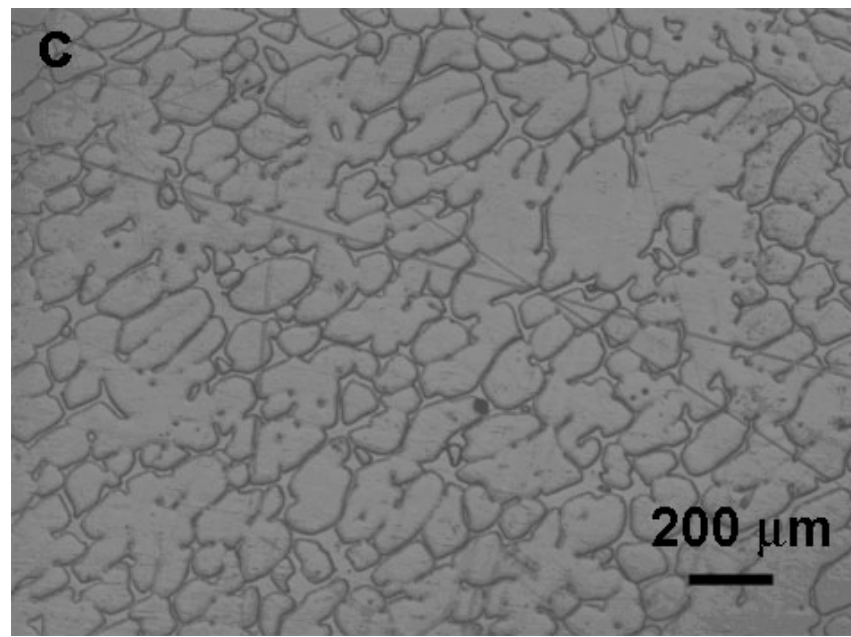

CF- $8,23 \% \delta$, unaged

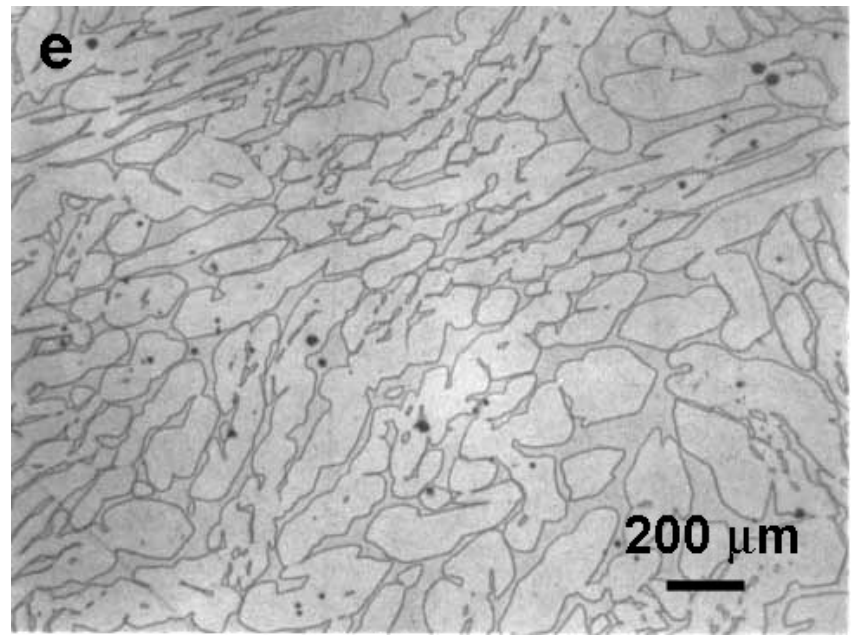

CF-8M, 28\% $\delta$, unaged (from ref. [4] )

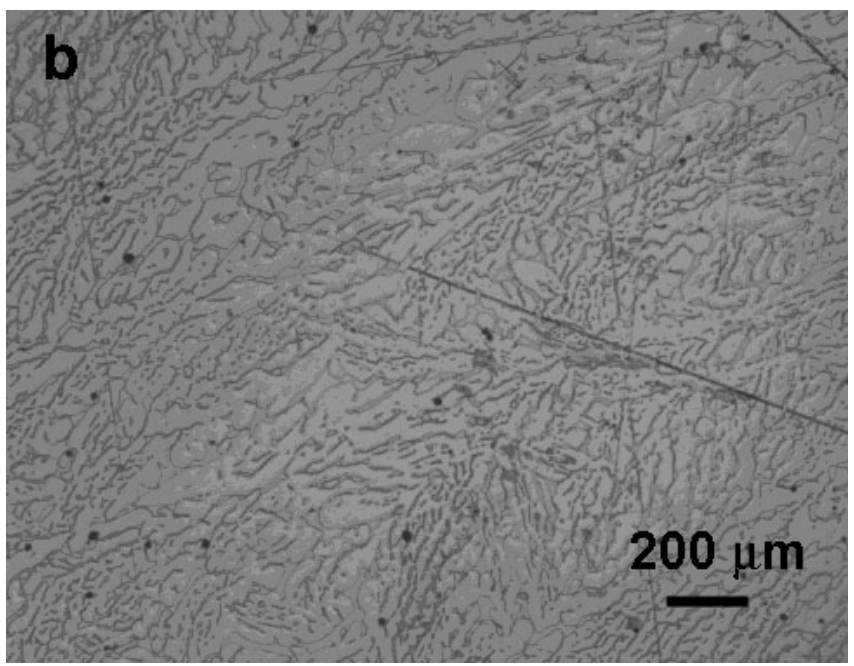

CF-3, 24\% $\delta$, aged

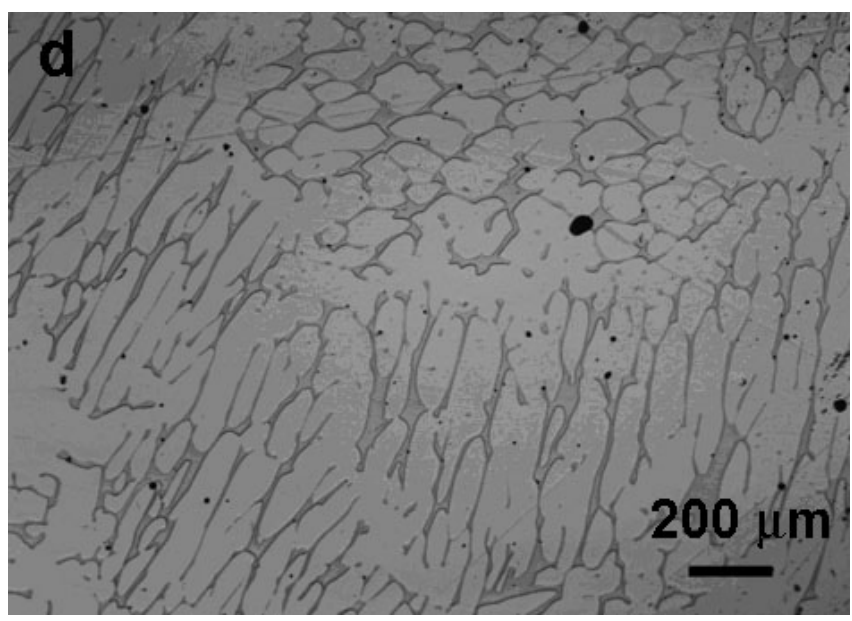

CF- $8,23 \% \delta$, aged

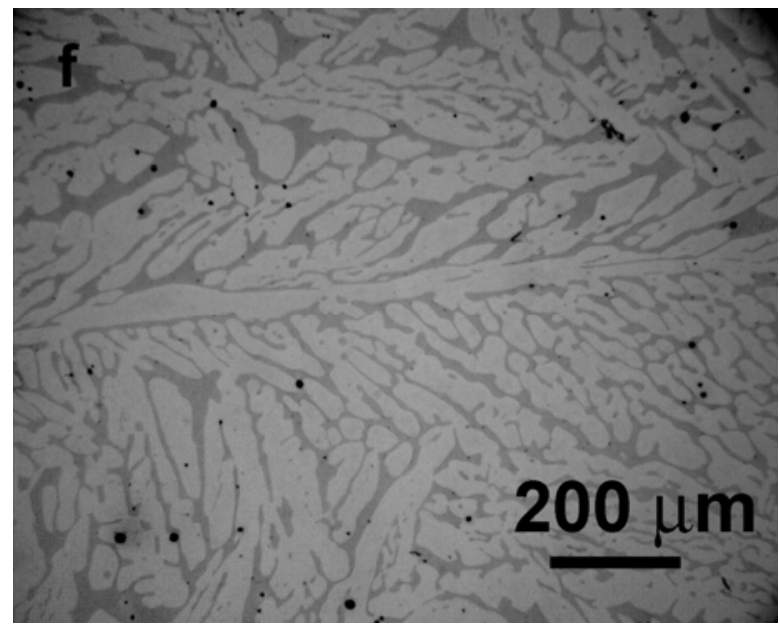

CF-8M, 28\% $\delta$, aged

Figure 1. Metallurgical images of the unaged and thermally aged CASS materials. 
Constrained by irradiation space, sub-sized compact tension (CT) specimens were used in this study. The sample was about 6.5 -mm thick (i.e., $1 / 4 \mathrm{~T}-\mathrm{CT}$ ) and $14 \mathrm{~mm}$ high. The starter notch size was about $6 \mathrm{~mm}$. To ensure an in-plane crack growth, side grooves approximately $5 \%$ of the thickness were machined on both sides of the sample. Figure 2 is a schematic of the sample used in this study. The red lines in the figure are electrical leads spot-welded on the specimen.
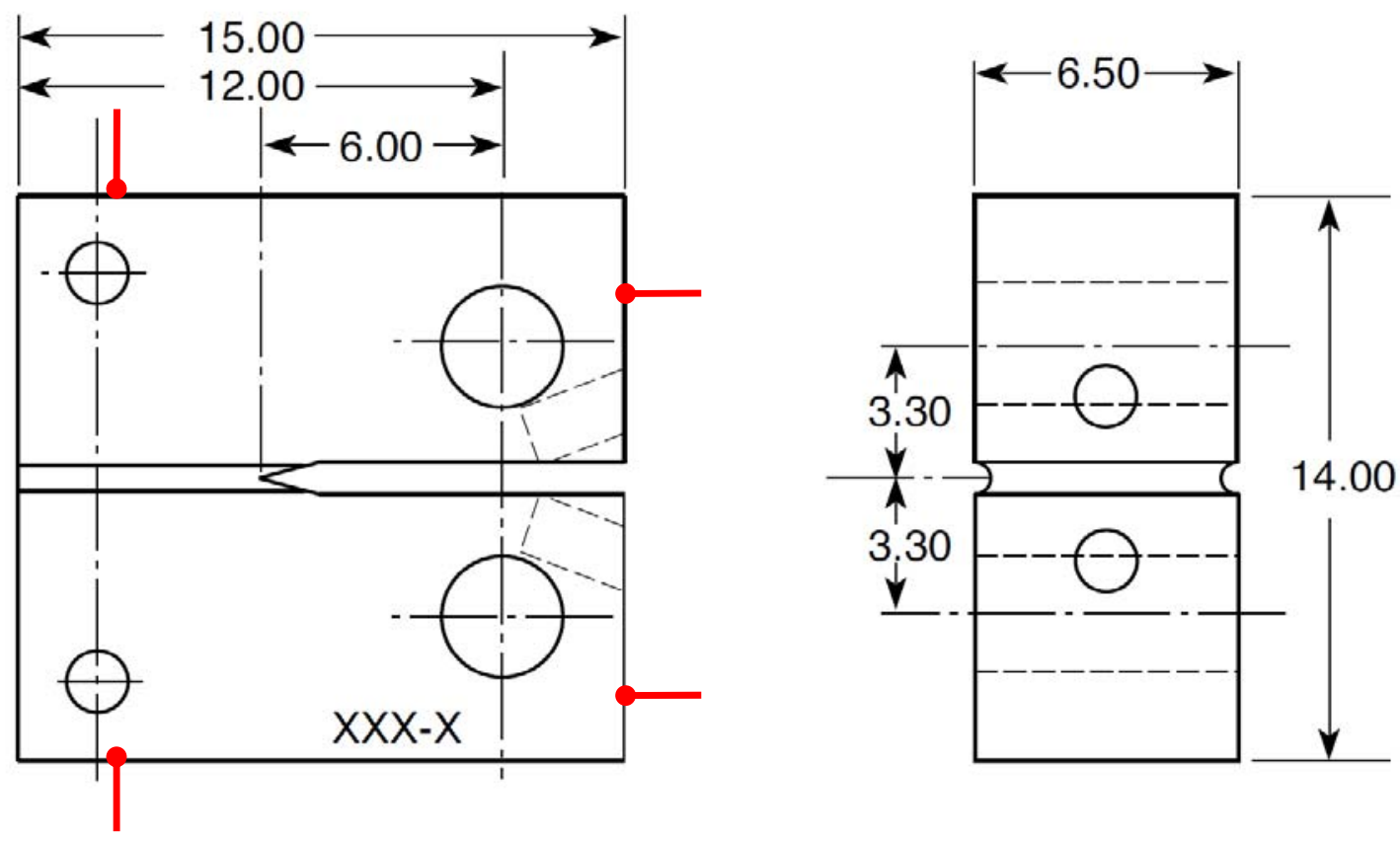

Figure 2. Schematic of 1/4T-CT specimen used in this study (red lines represent electrical leads).

\subsection{Irradiation}

All samples were irradiated in a helium-filled capsule in the Halden reactor, a boiling heavy water reactor in Norway. Figure 3 shows the assembly of the irradiation capsule. Some diskshaped samples for transmission electron microscopy analyses were also included in a cylindrical container in the irradiation capsule (item 7 in Fig. 3). The irradiation temperature was $\sim 315^{\circ} \mathrm{C}$, and two sets of melting alloy temperature monitors (item 5) were installed in the irradiation assembly.

During the irradiation experiment, three fluence monitor wires (Fe, $\mathrm{Ni}$ and $\mathrm{Al} / \mathrm{Co}$ alloy) were placed outside the irradiation capsule. After the irradiation, dosimetry was performed by the Halden researchers on these wires. Using the activation cross sections determined previously, they estimated the accumulated neutron fluence for the irradiation capsule. The obtained fast neutron fluence $(\mathrm{E}>1 \mathrm{MeV})$ was about $5.56 \times 10^{19} \mathrm{n} / \mathrm{cm}^{2}$, which corresponds to a displacement damage of 0.08 dpa for the samples. 


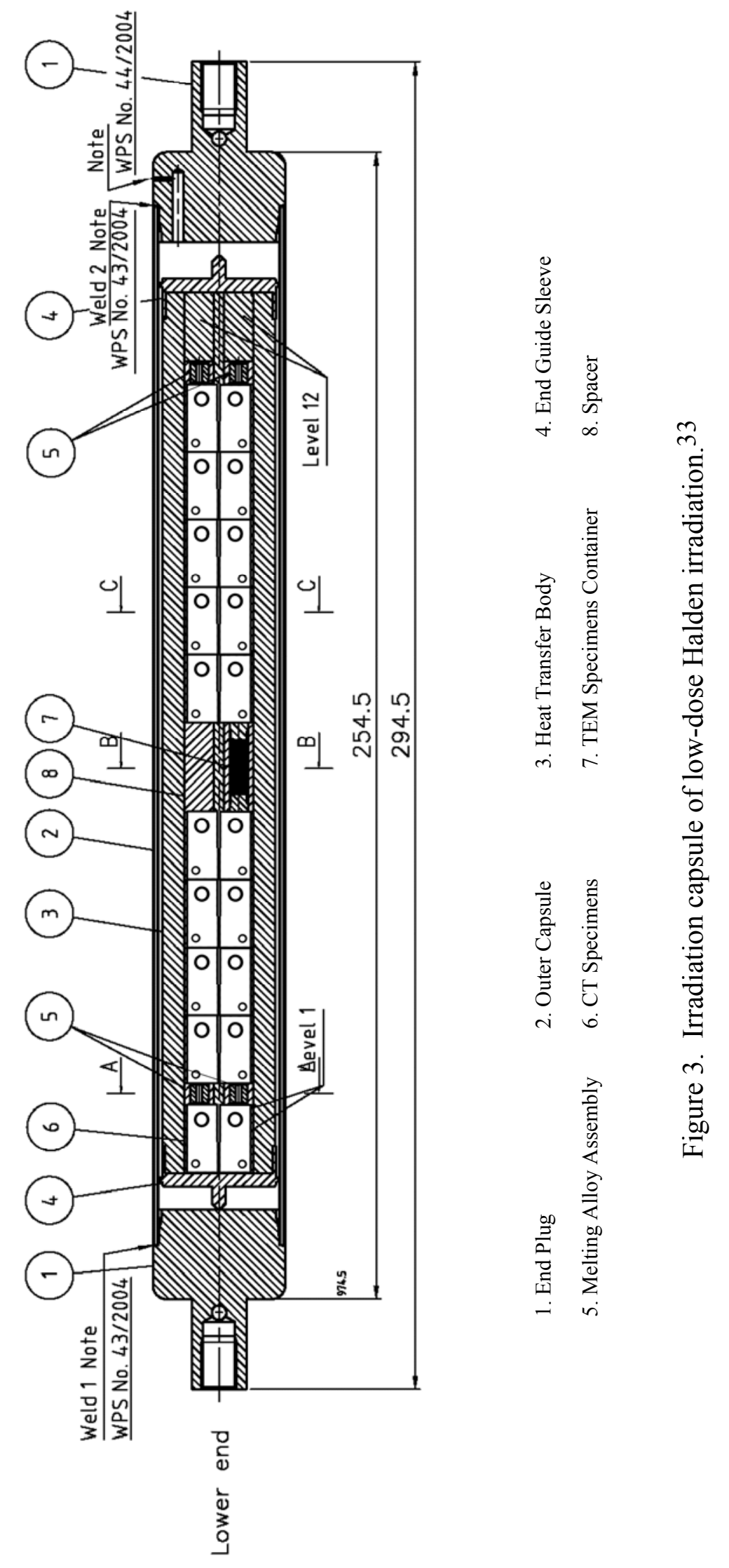




\subsection{Test Facility}

Two servo-hydraulic mechanical test systems located in the Irradiated Materials Laboratory (IML) at Argonne National Laboratory were used in this study. The IML is a radiological facility equipped with four air-atmosphere beta-gamma hot cells. The hot cells are maintained at a negative pressure with respect to the surroundings to maintain a proper radiological barrier. The two test systems are installed in separate hot cells. Each of the hot cells is equipped with its own loading frame, autoclave, load cell, linear voltage displacement transducer (LVDT), Instron control console, and data acquisition system.

In the current study, the tests were performed either in a simulated pressurized water reactor (PWR) environment or in a low-DO high-purity water environment. Both environments have low corrosion potentials, which are known to reduce the sensitivity of SSs to IASCC. ${ }^{34}$ The simulated PWR water contained $\sim 2 \mathrm{ppm}$ lithium, $\sim 1000 \mathrm{ppm}$ boron, and $\sim 2 \mathrm{ppm}$ hydrogen. The conductivity was about $20 \mu \mathrm{S} / \mathrm{cm}$. The low-DO high-purity water contained less than $10 \mathrm{ppb}$ dissolved oxygen and the conductivity was kept below $0.07 \mu \mathrm{S} / \mathrm{cm}$ during the tests. The test environments were provided by two water recirculation loops, and a schematic diagram of loop \#1 is shown in Fig. 4. Each loop consists of a storage tank, a high pressure pump, a regenerative heat exchanger, an autoclave, an ECP cell, a back-pressure regulator, two ion-exchange cartridges, and several heaters. The high-pressure section of the loop extends from the highpressure pump (item 13 in Fig. 4) through the back-pressure regulator (item 10 in Fig. 4). The rest of the loop is kept at low pressure. Over-pressurization of the high-pressure portion of the system is prevented by two rupture disks (items 3 and 15 in Fig. 4) located at the downstream of the high-pressure pump. The autoclaves are one-liter Type 316 stainless steel autoclaves and rated to $2900 \mathrm{psig}$ for $350^{\circ} \mathrm{C}$. The hot cell \#1 loop is a PWR water system, and hydrogen is used as cover gas. A hydrogen leak detection/alarm unit (items 36 - 38 in Fig. 4) is installed. For the hot cell \#2 loop, a low-corrosive-potential environment is simulated in high-purity water using a mixture of nitrogen with $4 \%$ hydrogen as cover gas. For both systems, water is circulated at a rate of $20-30 \mathrm{~mL} / \mathrm{min}$ through the autoclaves. The water conductivity and $\mathrm{pH}$ can be monitored with inline sensors. During the tests, the temperature and pressure of the autoclaves were kept at $\sim 320^{\circ} \mathrm{C}$ and $\sim 1800 \mathrm{psig}$, respectively. 


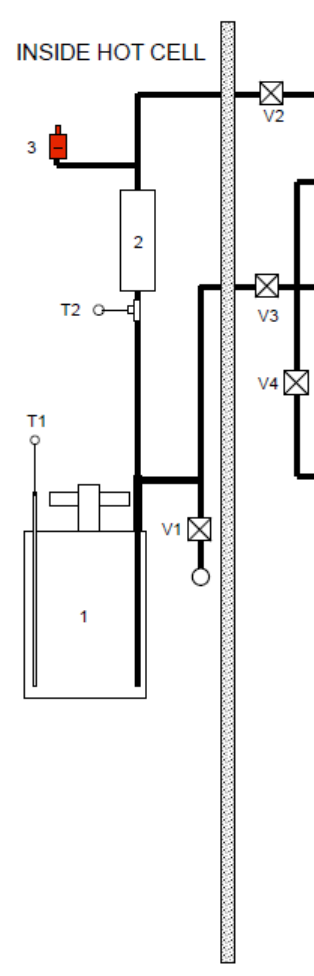

1. Autoclave

2. Autoclave preheater

3. Rupture disk

4. ECP preheater

5. ECP cell

6. Check valve

7. Air Cooled Coil

8. Heat exchanger

9. Chilled block

10. Back-pressure regulator

11. Ion exchange cartridge

12. Pressure relief valve

13. High-pressure pump

14. Accumulator
OUTSIDE HOT CELL

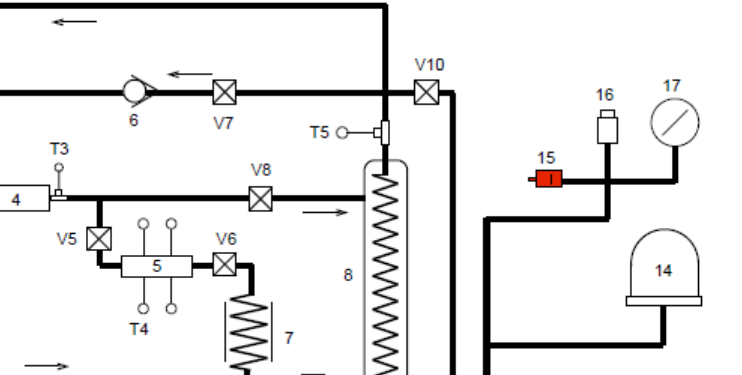

${ }_{35}$ 옹

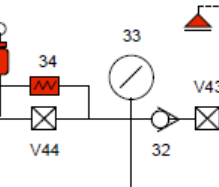

$\underline{5}_{38}$
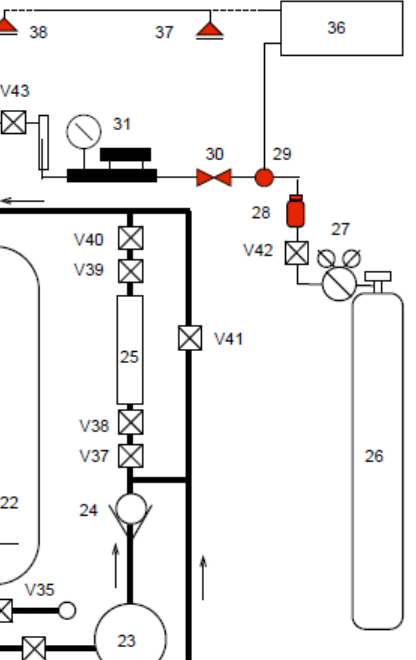

Figure 4. Recirculation water loop for Cell 1 of the IML (items in red are safety significant components)

\subsection{Crack Growth Rate and Fracture Toughness JR Curve Tests}

\subsubsection{Crack Growth Rate Test}

All CGR tests in this study were performed on the 1/4T-CT samples described above. Crack extensions were monitored with the direct current potential drop (DCPD) method during the tests. With this method, four electrical leads were spot welded on the CT sample (red lines shown in Fig. 2). A constant current was passed through the sample, and the potential drop across the crack mouth was measured and related to the crack extension of the CT sample with a calibrated correlation curve. 
The CGR tests were carried out in either a simulated PWR water environment or a low-DO highpurity water environment.

A typical CGR test is started with cyclic loading to pre-crack the sample in the test environment. A load ratio around $0.2-0.3$, frequency of $1-2 \mathrm{~Hz}$, and maximum stress intensity factor $\left(\mathrm{K}_{\max }\right)$ between 10 and $16 \mathrm{MPa} \mathrm{m}^{1 / 2}$ are used for pre-cracking. The objective of this step is to generate a sharp fatigue crack and to advance the crack tip passing beyond the area close to the machine notch. The properties at this area may have been altered by machining and do not represent the material's intrinsic behavior.

The stress intensity factor $K$ for a CT specimen is calculated by:

$$
K=\frac{P}{\left(B \cdot B_{N} \cdot W\right)^{1 / 2}} \cdot \frac{(2+a / W)}{(1-a / W)^{3 / 2}} \cdot f\left(\frac{a}{W}\right)
$$

where $P$ is applied load; $B$ is the specimen thickness; $B_{N}$ is the net specimen thickness (or distance between the roots of the side grooves); $a$ is crack length; and $W$ is specimen width (measured from the load line to the back edge of the specimen). The geometry factor $[\mathrm{f}(\mathrm{a} / \mathrm{W})]$ for a CT specimen is:

$$
f\left(\frac{a}{W}\right)=0.886+4.64\left(\frac{a}{W}\right)-13.32\left(\frac{a}{W}\right)^{2}+14.72\left(\frac{a}{W}\right)^{3}-5.60\left(\frac{a}{W}\right)^{4}
$$

Once a fatigue crack is initiated, a series of test steps is carried out with gradually increased rise times and load ratios. The measured CGRs in these test steps include the contributions from both mechanical fatigue and corrosion fatigue. With the change in loading conditions, the contribution of mechanical fatigue is gradually reduced while the environmental effect is enhanced. Figure 5 illustrates the principle of introducing environmentally assisted cracking in a test. The changes in test conditions should produce cyclic CGRs along the green line. The cyclic CGR test is transitioned to a SCC CGR test when a significant environmental enhancement is observed.

Because of the beneficial effects of ferrite and the reduced sensitivity to IASCC in low-corrosion potential environments, relatively low CGRs are expected at $0.08 \mathrm{dpa}$ for the CASS specimens. To measure SCC CGRs at such low growth rates, a considerable amount of time is needed to collect data for adequate measurements. Since the focus of this study was on embrittlement (i.e., loss of facture toughness), a limited amount of time was spent on collecting SCC CGR data. 


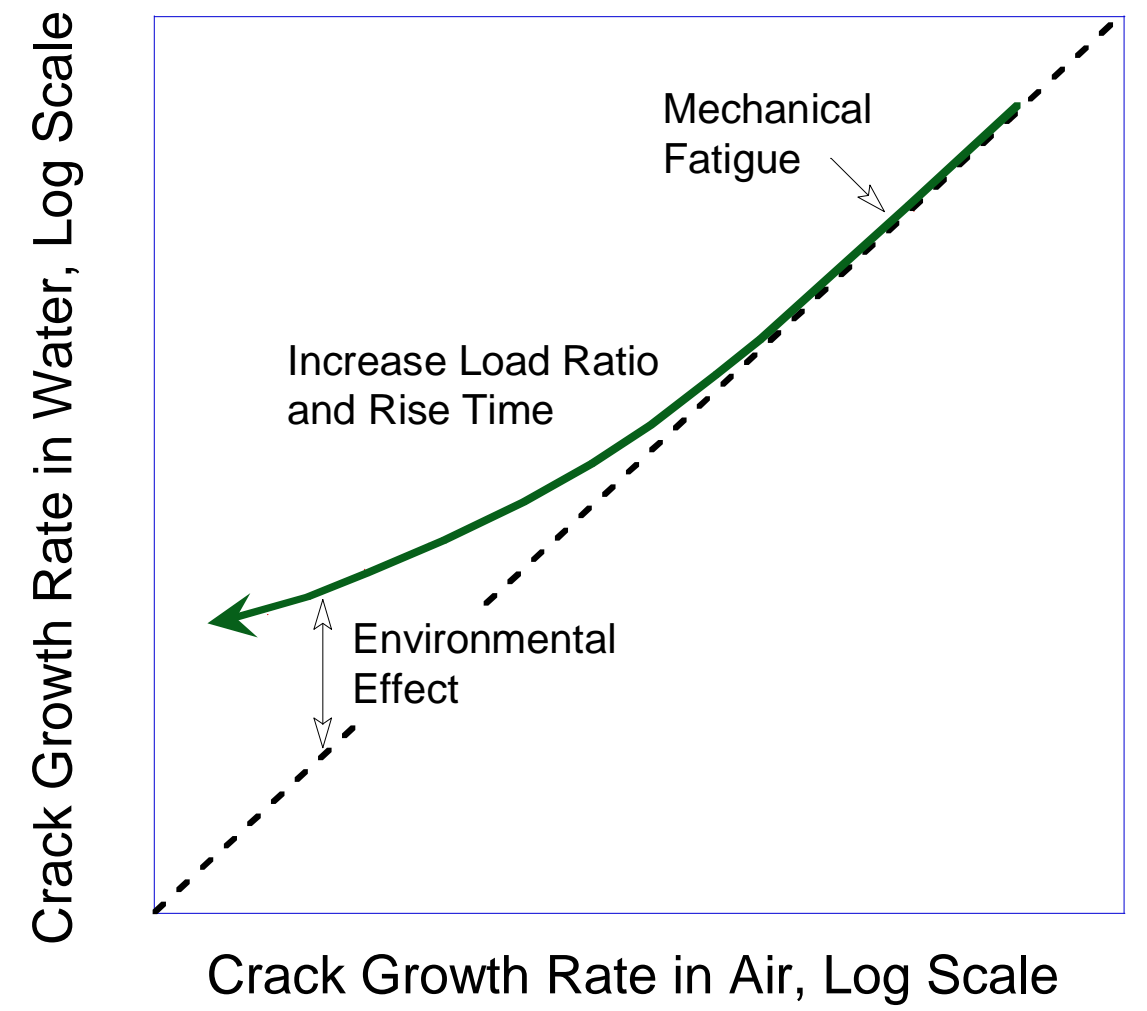

Figure 5. Schematic for inducing environmentally assisted cracking in test environment.

\subsubsection{Fracture Toughness JR Curve Test}

After each SCC CGR test, a fracture toughness JR curve test was conducted on the same sample in the test environment. This test was performed with a constant stain rate of $0.43 \mu \mathrm{m} / \mathrm{s}$, and the load and sample extension were recorded continuously outside the autoclave. The load-line displacement at load points was determined by subtracting the extension of the load train, which had been measured prior to the test. During the test, the loading was interrupted periodically, and the specimen was held at a constant extension to measure crack length with the DCPD method. Before each DCPD measurement, the sample stress was allowed to relax at a constant displacement for $30 \mathrm{~s}$.

The J-integral was calculated from the load $(P)$ vs. load-line displacement $(v)$ curve according to ASTM Specification E 1820-8a. ${ }^{35}$ The $J$ is the sum of the elastic and plastic components,

$$
J=J_{e l}+J_{p l}
$$

At a hold point $i$ corresponding to a crack length $a_{i}$, and $v_{i}$ and $P_{i}$ on the load vs. load-line displacement curve, the elastic component $J_{e l(i)}$ is given by:

$$
J_{e l(i)}=\frac{\left(K_{(i)}\right)^{2}(1-v)^{2}}{E}
$$


where $v$ is Poisson's ratio, and the stress intensity $K_{(i)}$ is calculated from Eqs. 1 and 2 . The plastic component $J_{p l(i)}$ is given by:

$$
J_{p l(i)}=\left[J_{p l(i-1)}+\left(\frac{\eta_{(i-1)}}{b_{(i-1)}}\right) \frac{A_{p l(i)}-A_{p l(i-1)}}{B_{N}}\right]\left[1-\gamma_{(i-1)} \frac{a_{(i)}-a_{(i-1)}}{b_{(i-1)}}\right]
$$

where $b_{(i-1)}$ is the remaining ligament at point $i-1 ; A_{p l(i)}$ is the area under the load vs. load-line displacement curve; and $B_{N}$ is the net specimen thickness. In addition, $\gamma_{(i)}$ and $\eta_{(i)}$ are factors that account for the crack growth effects on $J$ during the test and are expressed as:

$$
\begin{aligned}
& \eta_{(i-1)}=2.0+0.522 \frac{b_{(i-1)}}{W} \\
& \gamma_{(i-1)}=1.0+0.76 \frac{b_{(i-1)}}{W}
\end{aligned}
$$

The quantity $A_{p l(i)}-A_{p l(i-1)}$ is the increment of the plastic area under the load vs. load-line displacement curve between lines of constant plastic displacement at points $i-1$ and $i$. The plastic area under the load vs. load-line displacement curve is given by

$$
A_{p l(i)}=A_{p l(i-1)}+\frac{\left[P_{i}+P_{i-1}\right]\left[v_{p l(i)}-v_{p l(i-1)}\right]}{2}
$$

where the plastic components of the load-line displacement, $v_{p l(i)}$, are:

$$
v_{p l(i)}=v_{(i)}-P_{i} C_{L L(i)}
$$

where $v_{(i)}$ is the total load-line displacement, and $C_{L L(i)}$ is the compliance required to give the current crack length $a_{i}$, and can be determined as follows:

$$
C_{L L(i)}=\frac{\left[1.62+17.80\left(a_{i} / W\right)-4.88\left(a_{i} / W\right)^{2}+1.27\left(a_{i} / W\right)^{3}\right]}{E^{\prime} B_{e}\left[1-\left(a_{i} / W\right)^{2}\right]}
$$

where $B_{e}$ is the specimen effective thickness given by $B-\left(B-B_{N}\right)^{2} / B$, and $E^{\prime}=E /\left(1-v^{2}\right)$.

A JR curve is constructed by fitting the calculated J values and corresponding crack lengths to a power law relationship. The $J$ value at the intersection of the power law curve and the $0.2-\mathrm{mm}$ offset blunting line is reported. Note that a blunting line of four times flow stress $\left(4 \sigma_{f}\right)$ is recommended by Mills 5 for materials with high strain hardening coefficients, and has been used in the previous thermal aging studies on unirradiated CASS. ${ }^{4}$ To be consistent with the previous analyses, the same blunting line (i.e., $\mathrm{J} / 4 \sigma_{\mathrm{f}}$ ) was also used in the current work on irradiated CASS. 
In this study, the estimated flow stress of irradiated CASS is approximately 420-520 MPa. This relatively low strength allows a maximum $\mathrm{J}$ value of $280-360 \mathrm{~kJ} / \mathrm{m}^{2}$ for a typical $1 / 4 \mathrm{~T}-\mathrm{CT}$ specimen. The maximum crack extension is limited below $\sim 1.3 \mathrm{~mm}$ in most cases. Because of the low strength and high fracture toughness of CASS materials, the required crack tip constraint and upper limit of $\mathrm{J}$ integral are often invalid with the 1/4T-CT specimen. Thus, the J values determined from this study normally cannot be validated for $\mathrm{J}_{\mathrm{IC}}$ per ASTM E182-8a.

\subsubsection{Fractographic Examination}

After each CGR/JR test, the final crack size was marked by fatigue cycling in an air atmosphere at room temperature. The specimen was then fractured, and the fracture surface was examined by a scanning electron microscopy (SEM). Since the sample was highly radioactive, a two-step replication technique was developed for the fractographic examination. After cleaning the tested sample remotely using manipulators, we used a two-part synthetic compound to produce a negative replica of the fracture surface inside the hot cell. The negative replica was then removed from the hot cell and transferred to a radiological fume hood for decontamination. The second step of casting was to apply a low-viscosity epoxy on the surface of the negative replica. The cast was kept at approximately $70^{\circ} \mathrm{C}$ for several days to harden the epoxy replica. The negative replica was then removed. The obtained epoxy replica was coated with a layer of gold before it was transferred for SEM examination.

The CGR test and JR test regions were identified on the SEM images and their fracture morphologies were analyzed. The physical crack length was also measured on the images, and a 9/8 averaging technique was used to account for the uneven extensions at the crack front. With this technique, nine measurements were taken along the crack front spaced across the width of the sample at equal intervals. The two near-surface measurements were averaged, and the resultant value was averaged with the remaining seven measurements to obtain the average crack length. All crack extensions determined from the DCPD method were scaled proportionately to match the final SEM-measured crack length. 


\section{Results}

Seven CASS specimens from three heats of CASS were tested in the current study. The test matrix is shown in Table 3. The specimens were unaged and thermally aged pairs and had been irradiated to an identical dose $(\sim 0.08 \mathrm{dpa})$ in the Halden reactor. The CF-3 specimens were tested in either low-DO high-purity water or PWR water, and all CF-8 and CF-8M specimens were tested in low-DO high-purity water.

Table 3. Test matrix of low-dose CASS specimens irradiated at the Halden reactor.

\begin{tabular}{cccccccc}
\hline Sample ID. & Heat ID. & \multicolumn{1}{c}{ Materials } & Test Environment & Facility & CGR & JR & SEM \\
\hline A-1 & 69 & CF-3, 24\% $\delta$, unaged & PWR & Cell 1 & $\sqrt{ }$ & - & $\sqrt{ }$ \\
A-2 & 69 & CF-3, 24\% $\delta$, unaged & Low-DO high-purity & Cell 2 & $\sqrt{ }$ & $\sqrt{ }$ & $\sqrt{ }$ \\
B-1 & 69 & CF-3, 24\% $\delta$, aged & PWR & Cell 1 & $\sqrt{ }$ & $\sqrt{ }$ & $\sqrt{ }$ \\
\hline E-1 & 68 & CF-8, 23\% $\delta$, unaged & Low-DO high-purity & Cell 2 & $\sqrt{ }$ & $\sqrt{ }$ & $\sqrt{ }$ \\
F-1 & 68 & CF-8, 23\% $\delta$, aged & Low-DO high-purity & Cell 2 & $\sqrt{ }$ & $\sqrt{ }$ & $\sqrt{ }$ \\
\hline I-1 & 75 & CF-8M, 28\% $\delta$, unaged & Low-DO high-purity & Cell 2 & $\sqrt{ }$ & $\sqrt{ }$ & $\sqrt{ }$ \\
J-1 & 75 & CF-8M, 28\% $\delta$, aged & Low-DO high-purity & Cell 2 & $\sqrt{ }$ & $\sqrt{ }$ & $\sqrt{ }$ \\
\hline
\end{tabular}

\subsection{CF-3 Cast Stainless Steel}

\subsubsection{Unaged CF-3 Cast Stainless Steel}

\subsubsection{Specimen A-1 tested in simulated PWR water}

\section{Crack growth rate test}

Specimen A-1 was a CF-3 CASS sample (Heat 69) tested in the simulated PWR water environment. The specimen had $\sim 24 \%$ ferrite and was in the as-cast condition. The objective of this test was to compare the results with those from an identical test performed in high-purity water with low DO. Also, the CGR results of this sample were compared with those obtained from its thermally aged equivalent. The test conditions and results are summarized in Table 4, and a crack-length history plot is shown in Fig. 6. Note that the starting crack length was about 1 mm longer than a normal value for a 1/4T-CT specimen. This crack extension was due to an interruption of the test to correct a loose DCPD lead found during pre-cracking. The initial crack length $(6.802 \mathrm{~mm})$ reported in Table 4 was later determined with SEM images on the fracture surface.

The specimen was pre-cracked in the PWR environment with a triangular waveform at $1 \mathrm{~Hz}$, a maximum stress intensity factor of $\sim 24 \mathrm{MPa} \mathrm{m}^{1 / 2}$, and load ratio of 0.2 . After about $200 \mu \mathrm{m}$ extension, the load ratio was increased while the stress intensity factor and cyclic frequency were reduced gradually. The measured CGRs in the initial stage of the pre-cracking (test periods $a-d$ ) followed closely with the fatigue growth rates in air. Next, several test periods were carried out with saw-tooth waveforms and increased rise times to stimulate environmentally assisted cracking. The environmental enhancement of CGRs started to appear and became stabilized 
after some additional crack extension. The cyclic CGR data obtained from this test are plotted against fatigue CGRs in air as shown in Fig. 7. The fatigue CGRs are estimated for cyclic test periods based on James and Jones ${ }^{37}$ with the load ratios and rise times. A corrosion fatigue curve proposed by Shack and Kassner ${ }^{38}$ for unirradiated SSs in 0.2-ppm DO water at $290^{\circ} \mathrm{C}$ is also included in the figure as a reference. Obviously, the corrosion fatigue response of this sample is lower than that of typical SSs, suggesting good IASCC resistance of CASS in PWR water.

After the cyclic CGR test, the specimen was subjected to a constant stress intensity factor of $\sim 24$ $\mathrm{MPa} \mathrm{m}{ }^{1 / 2}$ with periodic partial unloading (PPU) every 2 hours. The measured SCC CGR was about $4.8 \times 10^{-11} \mathrm{~m} / \mathrm{s}$, a factor of four lower than that of the NUREG-0313 curve, 36 a SCC disposition curve based on unirradiated SSs tested in high-DO environment. The SCC response of this sample will be discussed at the end of this section along with the other CGR data obtained from the same heat.

Table 4. Crack growth rates of specimen A-1 (0.08-dpa unaged CF-3 sample with $24 \% \delta$ ferrite) in PWR water. ${ }^{\mathrm{a}}$

\begin{tabular}{|l|l|l|l|l|l|l|l|l|l|l|l|}
\hline $\begin{array}{l}\text { Test } \\
\text { Period }\end{array}$ & $\begin{array}{l}\text { Test } \\
\text { Time, }\end{array}$ & $\begin{array}{l}\text { Test } \\
\text { Temp., } \\
{ }^{\circ} \mathrm{C}\end{array}$ & $\begin{array}{l}\text { Load } \\
\text { Ratio }\end{array}$ & $\begin{array}{l}\text { Rise } \\
\text { Time, } \\
\mathrm{s}\end{array}$ & $\begin{array}{l}\text { Return } \\
\text { Time, } \\
\mathrm{s}\end{array}$ & $\begin{array}{l}\text { Hold } \\
\text { Time, } \\
\mathrm{s}\end{array}$ & $\begin{array}{l}\text { Kmax, } \\
\mathrm{MPa} \mathrm{m}^{1 / 2}\end{array}$ & $\begin{array}{l}\Delta \mathrm{K}, \\
\mathrm{MPa} \mathrm{m}^{1 / 2}\end{array}$ & $\begin{array}{l}\text { CGR in } \\
\text { Env., } \\
\mathrm{m} / \mathrm{s}\end{array}$ & $\begin{array}{l}\text { CGR } \\
\text { in Air, } \\
\mathrm{m} / \mathrm{s}\end{array}$ & $\begin{array}{l}\text { Crack } \\
\text { Length, } \\
\mathrm{mm}\end{array}$ \\
\hline Start & 63.9 & & & & & & & & & & \\
\hline $\mathrm{a}$ & 64.8 & 319 & 0.21 & 0.43 & 0.43 & 0.07 & 24.3 & 19.2 & $1.58 \mathrm{E}-07$ & $2.04 \mathrm{E}-07$ & 7.009 \\
\hline $\mathrm{b}$ & 66 & 319 & 0.31 & 0.41 & 0.41 & 0.09 & 23.8 & 16.4 & $1.17 \mathrm{E}-07$ & $1.43 \mathrm{E}-07$ & 7.218 \\
\hline $\mathrm{c}$ & 68.6 & 319 & 0.41 & 0.78 & 0.78 & 0.22 & 23.1 & 13.6 & $3.21 \mathrm{E}-08$ & $4.47 \mathrm{E}-08$ & 7.340 \\
\hline $\mathrm{d}$ & 72.3 & 319 & 0.41 & 1.54 & 1.54 & 0.46 & 21.9 & 12.8 & $9.77 \mathrm{E}-09$ & $1.89 \mathrm{E}-08$ & 7.395 \\
\hline $\mathrm{e}$ & 87.6 & 319 & 0.46 & 2.96 & 1.48 & 1.04 & 20.3 & 11.0 & $2.89 \mathrm{E}-10$ & $6.18 \mathrm{E}-09$ & 7.403 \\
\hline $\mathrm{f}$ & 91 & 319 & 0.41 & 3.08 & 1.54 & 0.92 & 22.2 & 13.1 & $9.46 \mathrm{E}-09$ & $1.01 \mathrm{E}-08$ & 7.462 \\
\hline $\mathrm{g}$ & 94.1 & 320 & 0.41 & 7.69 & 1.54 & 2.31 & 22.4 & 13.2 & $5.67 \mathrm{E}-09$ & $4.17 \mathrm{E}-09$ & 7.503 \\
\hline $\mathrm{h}$ & 103 & 320 & 0.46 & 22.6 & 3.76 & 7.42 & 22.6 & 12.2 & $1.51 \mathrm{E}-09$ & $1.16 \mathrm{E}-09$ & 7.535 \\
\hline $\mathrm{i}$ & 114.3 & 320 & 0.46 & 45.1 & 3.76 & 14.9 & 22.7 & 12.3 & $7.63 \mathrm{E}-10$ & $5.86 \mathrm{E}-10$ & 7.558 \\
\hline $\mathrm{j}$ & 118.7 & 319 & 0.41 & 15.3 & 3.83 & 4.66 & 23.0 & 13.6 & $4.61 \mathrm{E}-09$ & $2.27 \mathrm{E}-09$ & 7.602 \\
\hline $\mathrm{k}$ & 127.9 & 319 & 0.41 & 46.0 & 3.83 & 14.0 & 23.0 & 13.7 & $1.25 \mathrm{E}-09$ & $7.72 \mathrm{E}-10$ & 7.632 \\
\hline $\mathrm{l}$ & 150.3 & 318 & 0.40 & 114.9 & 9.19 & 35.1 & 23.0 & 13.7 & $3.90 \mathrm{E}-10$ & $3.13 \mathrm{E}-10$ & 7.655 \\
\hline $\mathrm{m}$ & 168.7 & 319 & 0.40 & 385.6 & 9.25 & 114.4 & 23.9 & 14.3 & $3.56 \mathrm{E}-10$ & $1.05 \mathrm{E}-10$ & 7.673 \\
\hline 1 & 209 & 318 & 0.40 & 12 & 12 & 7200 & 23.9 & 14.4 & $4.83 \mathrm{E}-11$ & $5.75 \mathrm{E}-12$ & 7.684 \\
\hline
\end{tabular}

a Simulated PWR water with 2 ppm Li and 1000 ppm B. DO $<10$ ppb. Conductivity $\sim 20 \mu \mathrm{S} / \mathrm{cm}$.

$\mathrm{b}$ Determined from the SEM image after the test. 
(a)

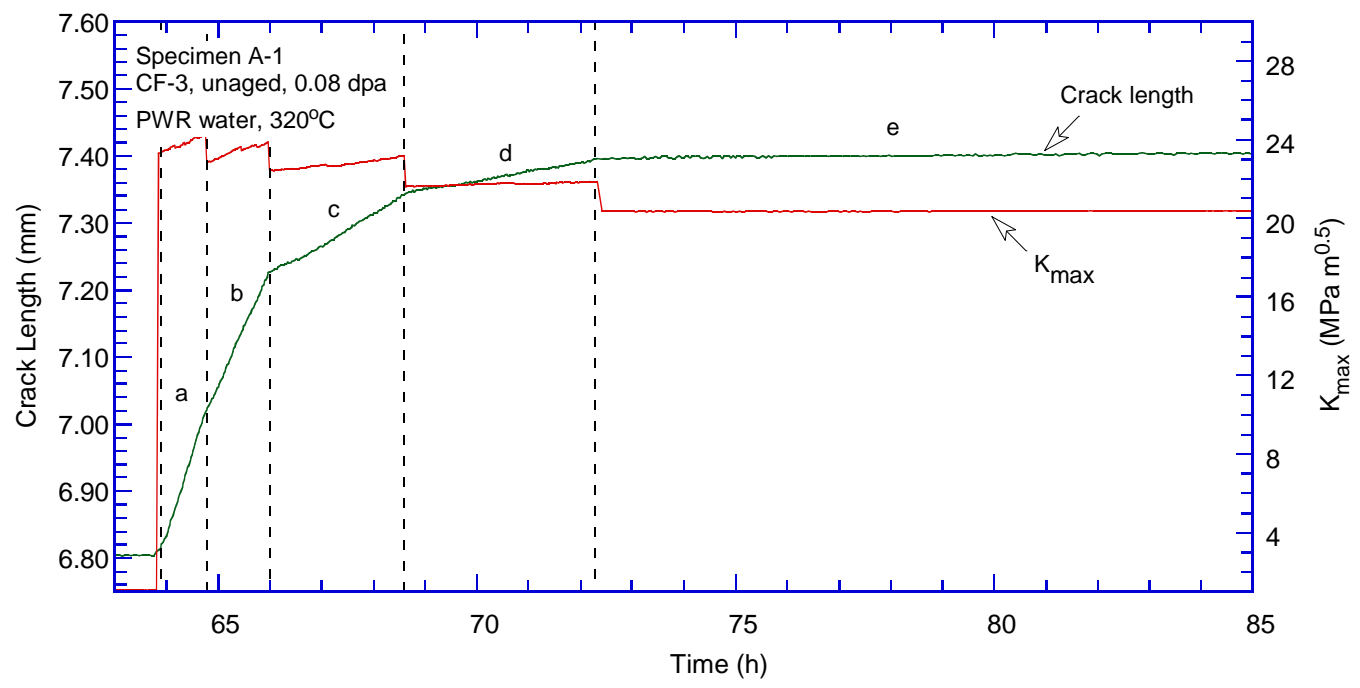

(b)

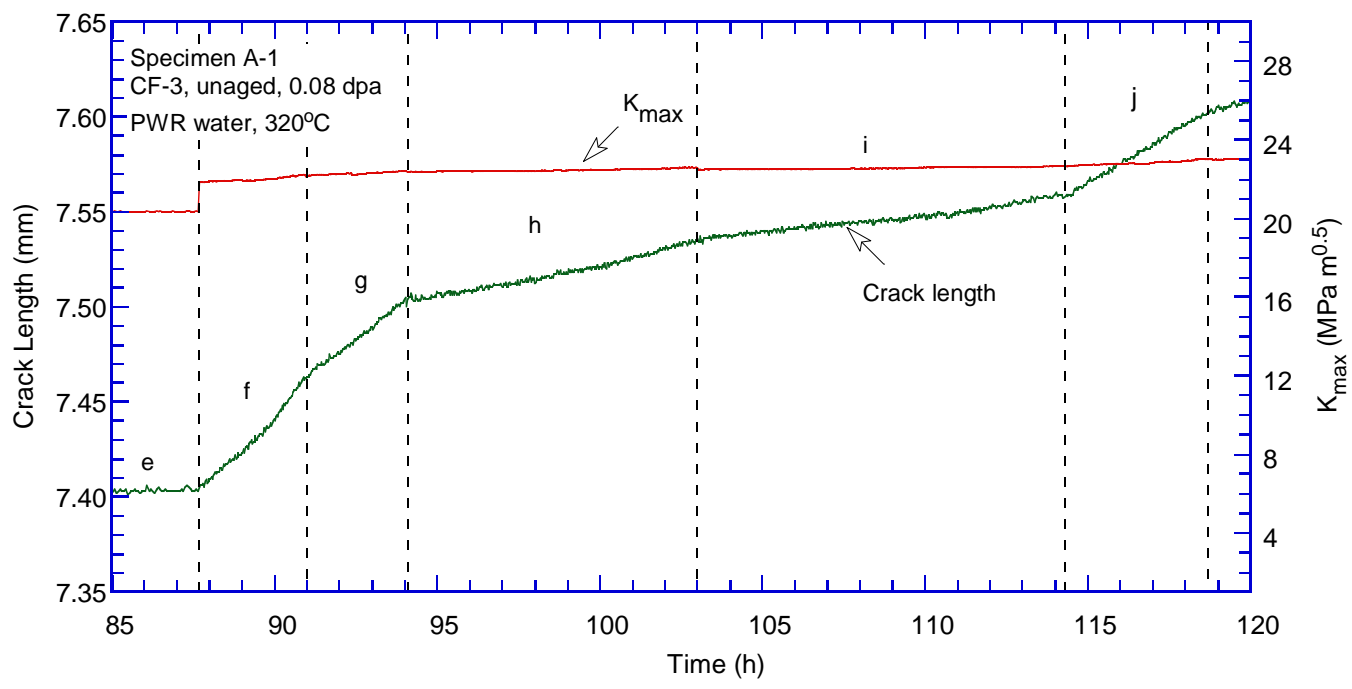

(c)

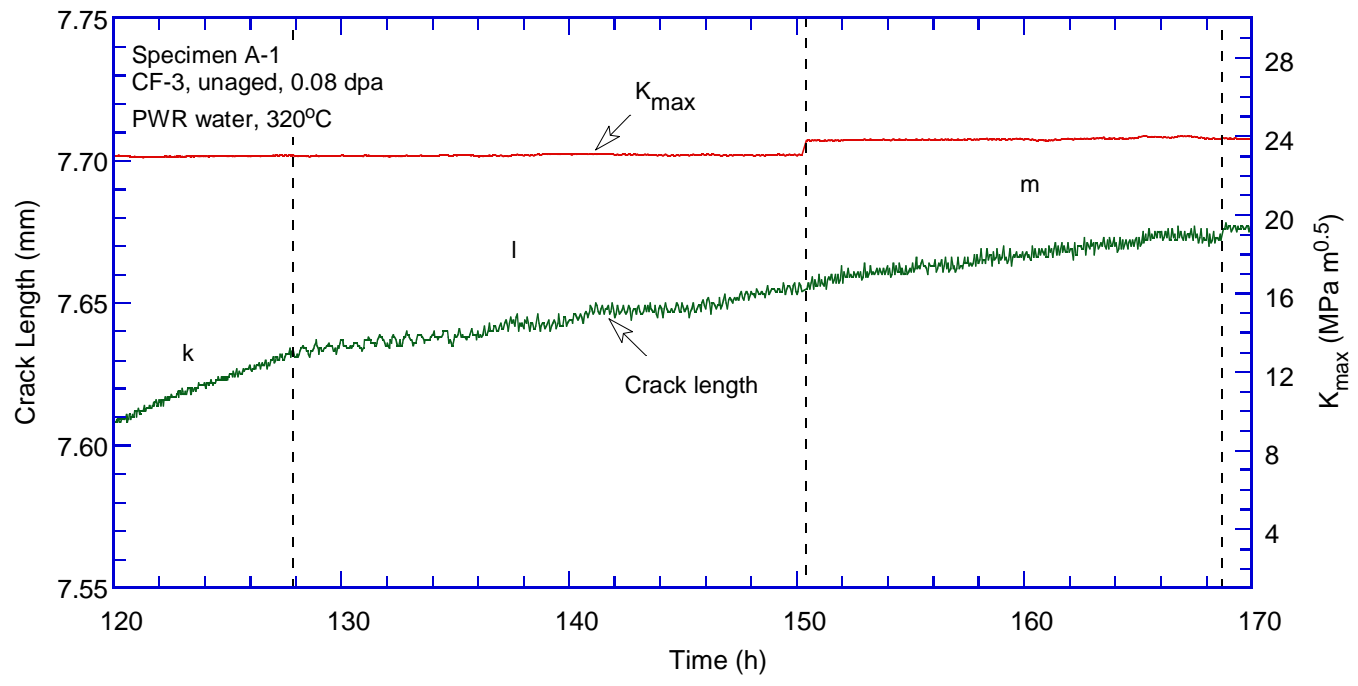

Figure 6. Crack-length-vs.-time plot for specimen A-1 (0.08-dpa unaged CF-3 with 24\% ferrite): test periods (a) a-e, (b) f-j, (c) k-m, and (d) 1 . 
(d)

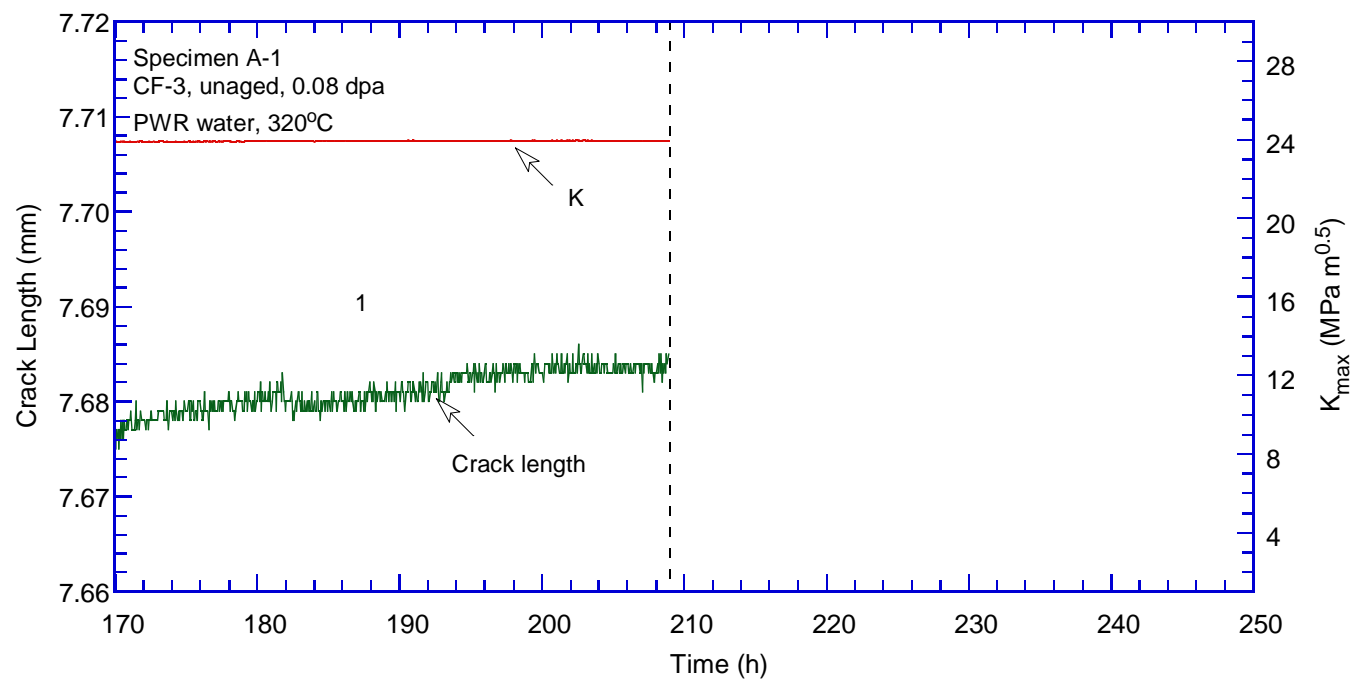

Figure 6. (Contd.)

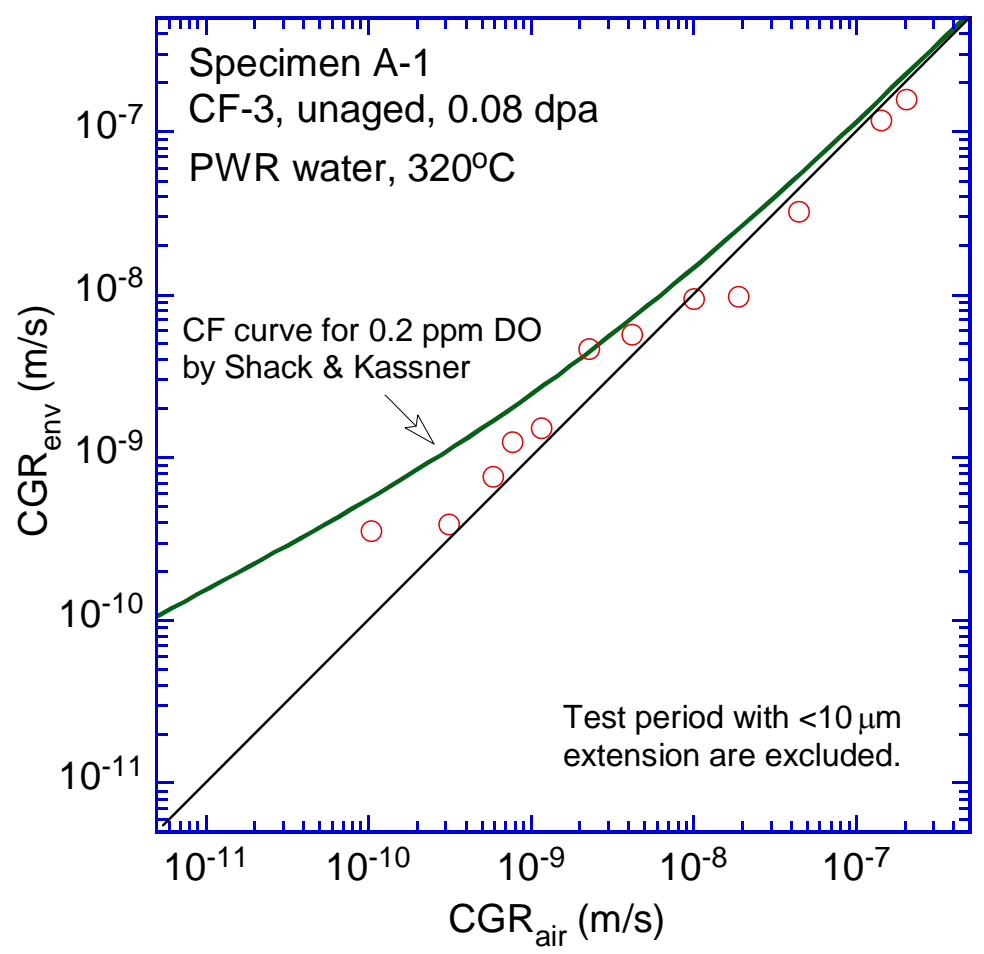

Figure 7. Cyclic CGRs of Specimen A-1. 


\section{$\underline{\text { Fractographic examination }}$}

After the test, the specimen was pulled apart in an air atmosphere at room temperature, and the fracture surface was examined with SEM. Figure 8 shows the entire crack front of specimen A1. The straight line in the middle of the picture corresponds to the restart of pre-cracking. Figure 9 is an enlarged view along the central section of the specimen. Transgranular cleavage fracture is the dominant morphology throughout the CGR region. Figure 10 shows the typical river pattern of cleavage cracking at the beginning and the end of the CGR test region. Vermicular ferrite at dendrite cores can also be seen in a few places on the fracture surface. As shown in Fig. 11, fewer slip ledges can be seen within ferrite, suggesting that the ferrite dendrite core might be deformed to a lesser extent than the surrounding austenite. Beyond the CGR test, the dominant fracture mode is ductile dimples resulting from microvoid coalescence. 


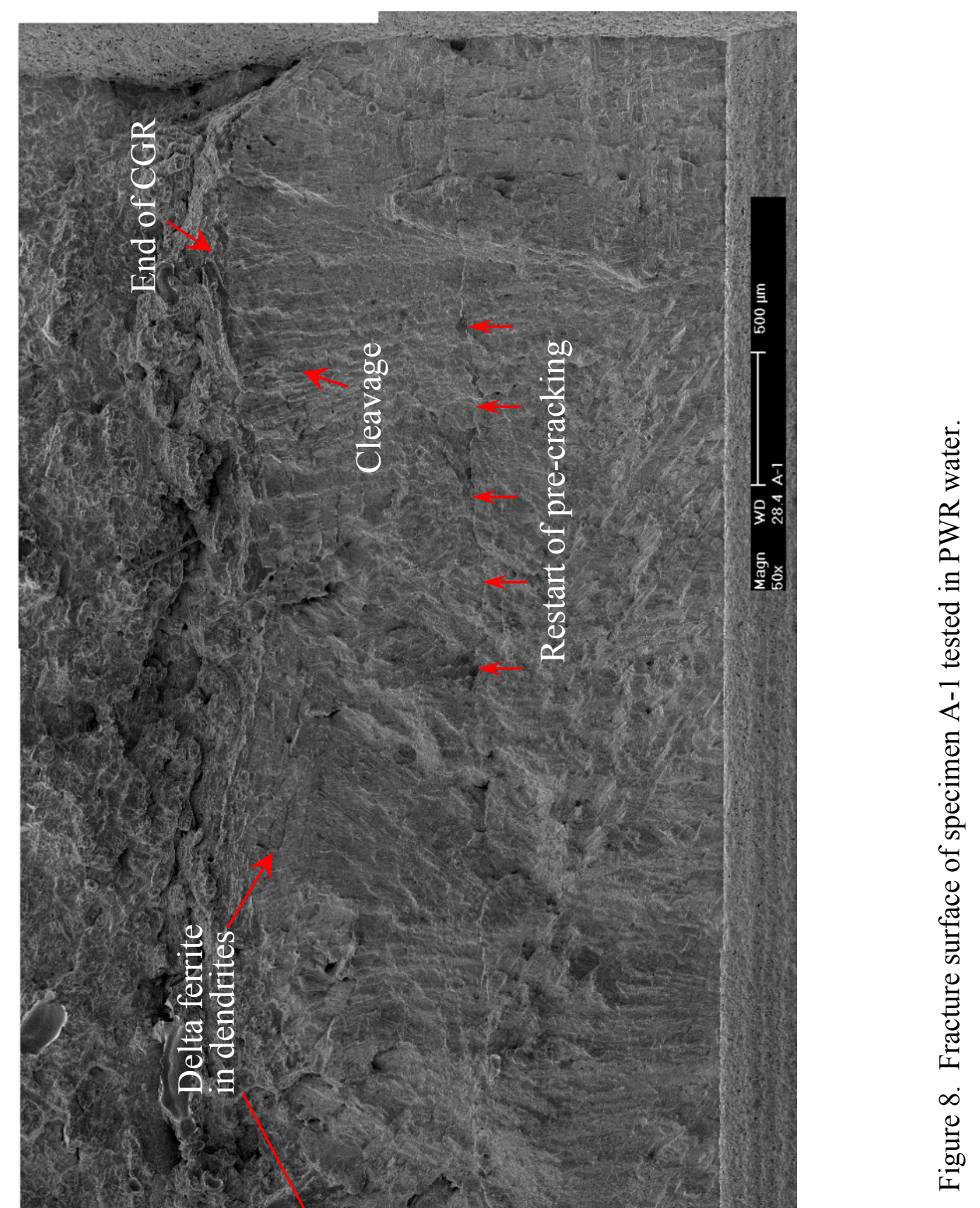

Crack advance 


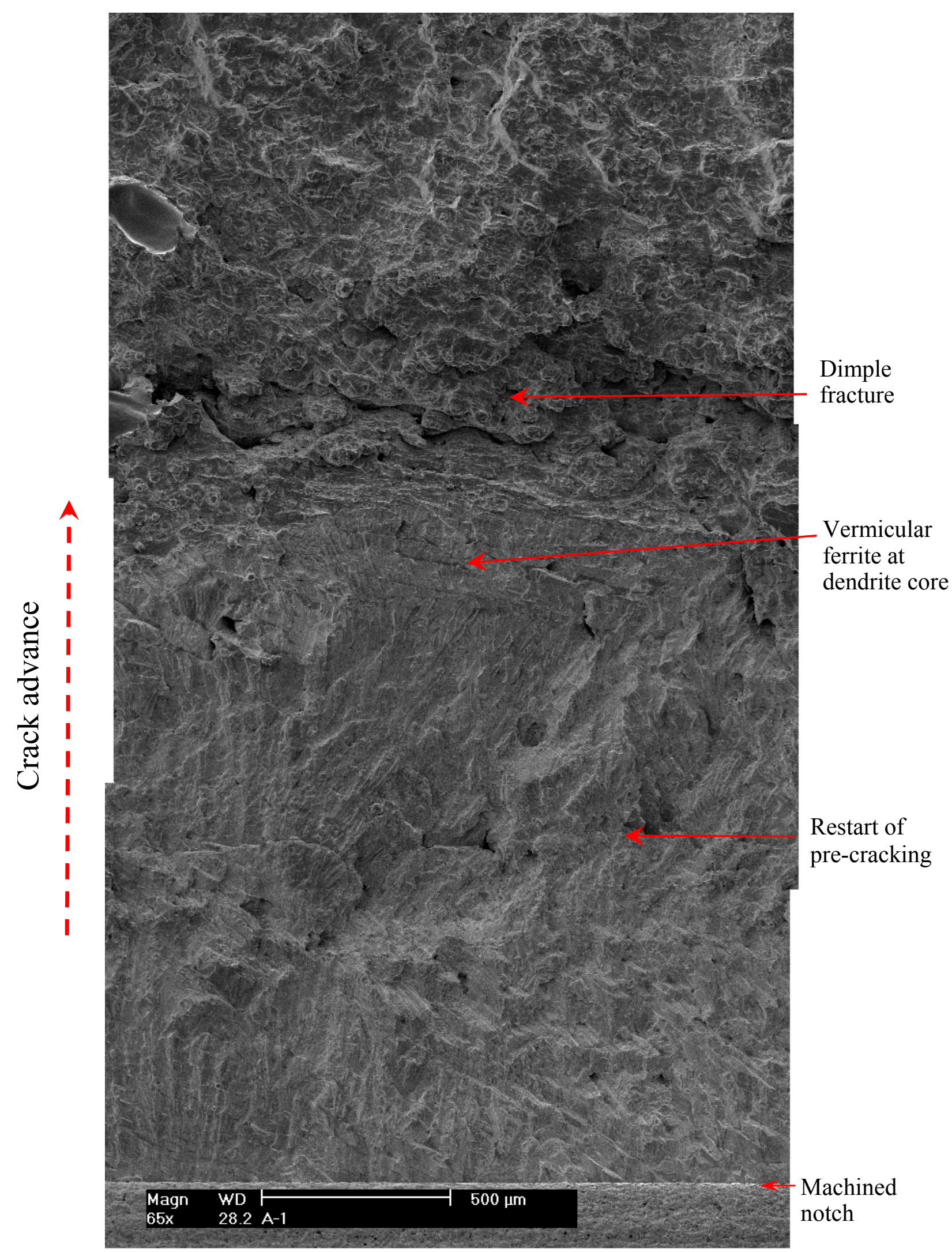

Figure 9. Fracture surface of specimen A-1 along the sample central line. 

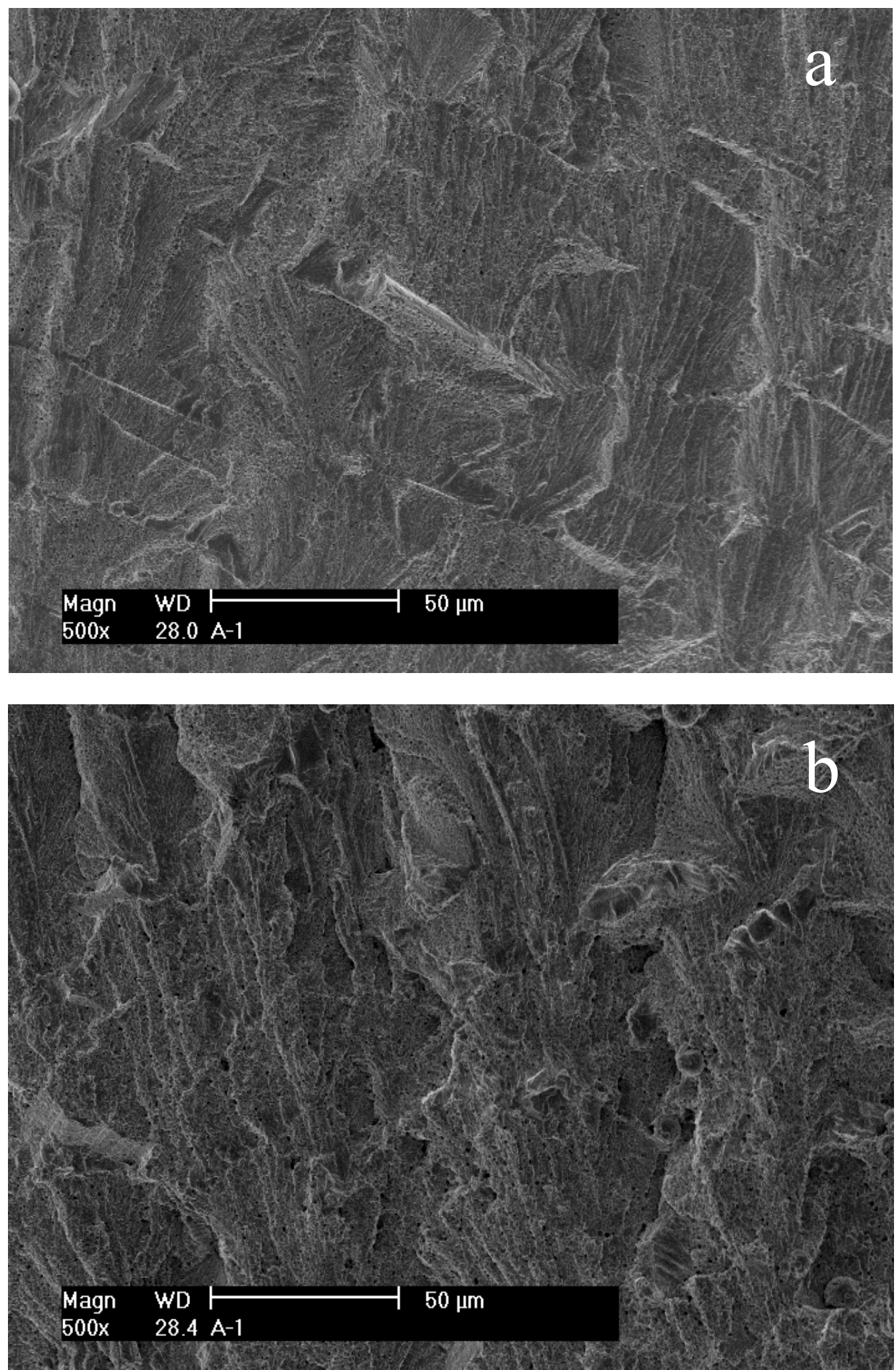

Figure 10. Cleavage fracture in specimen A-1: (a) pre-cracking, and (b) end of the CGR test. Crack propagation from bottom to top. 


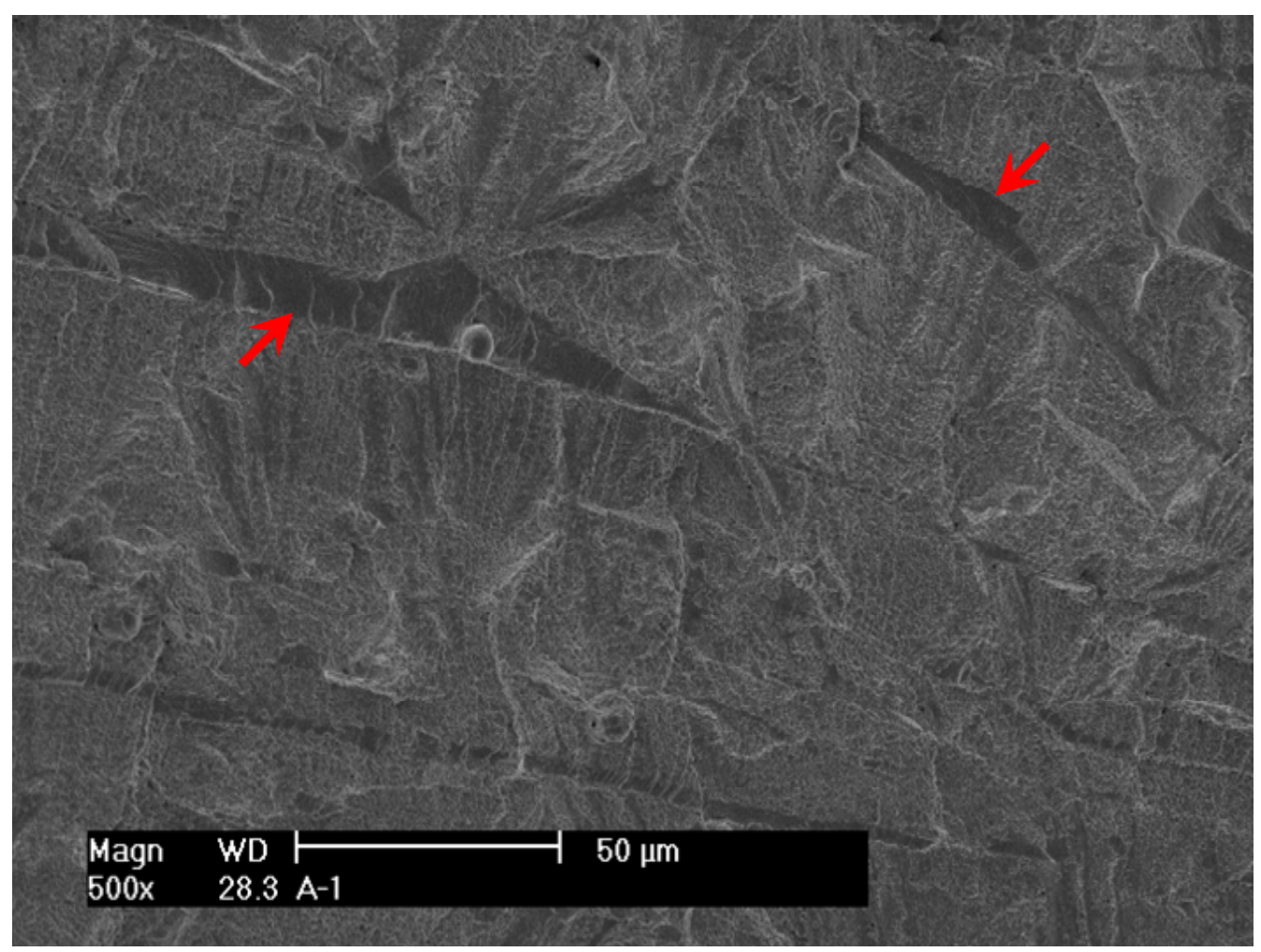

Figure 11. Fracture surface of specimen A-1 showing that delta ferrite deformed to a lesser extent than austenite. Crack propagation from bottom to top.

\subsubsection{Specimen A-2 tested in low-DO high-purity water}

\section{$\underline{\text { Crack growth rate test }}$}

Specimen A-2 was an unaged CF-3 CASS with 24\% ferrite (Heat 69), identical to specimen A1. This sample was tested in high-purity water with low DO. The objective was to compare the results with those from specimen A-1, which was tested in PWR water. In addition, the fracture toughness of this specimen was compared with that of thermally aged CF-3 CASS. The CGR test conditions and results are summarized in Table 5, and a crack-length history plot is shown in Fig. 12.

Pre-cracking in this sample was started with a triangle waveform at $1 \mathrm{~Hz}$. The applied maximum stress intensity factor and load ratio were $\sim 17 \mathrm{MPa} \mathrm{m}^{1 / 2}$ and $\sim 0.35$, respectively. The initial cyclic CGRs were comparable to fatigue growth rates but were quickly diminished as the load ratio was increased to 0.5 . After lowering the load ratio of 0.4 and increasing the frequency to 1 $\mathrm{Hz}$, the high growth rate was re-established in test period $g$ over a 100 - $\mu \mathrm{m}$ crack extension. Next, the rise time was increased gradually while the maximum stress intensity factor and load ratio were kept approximately the same. In the following test periods, environmentally enhanced cracking started to appear and became evident with further increases in rise time and load ratio. By the end of test period $s$, the measured CGR was more than one order of magnitude higher than the fatigue growth rate in air. All cyclic CGRs obtained from this sample are plotted in Fig. 13 along with the corrosion fatigue curve for unirradiated SSs in water with $0.2 \mathrm{ppm}$ DO. A 
comparison between Figs. 7 and 13 shows that the cyclic CGRs of specimen A-1 is slightly lower than that of specimen A-2.

Table 5. Crack growth rates of specimen A-2 (0.08-dpa unaged CF-3 with $24 \% \delta$ ferrite) in lowDO high-purity water environment.

\begin{tabular}{|c|c|c|c|c|c|c|c|c|c|c|c|}
\hline $\begin{array}{l}\text { Test } \\
\text { Period }\end{array}$ & $\begin{array}{l}\text { Test } \\
\text { Time, } \\
\mathrm{h}\end{array}$ & $\begin{array}{l}\text { Test } \\
\text { Temp., } \\
{ }^{\circ} \mathrm{C} \\
\end{array}$ & $\begin{array}{l}\text { Load } \\
\text { Ratio }\end{array}$ & $\begin{array}{l}\text { Rise } \\
\text { Time, } \\
\text { S }\end{array}$ & $\begin{array}{l}\text { Return } \\
\text { Time, } \\
\mathrm{s}\end{array}$ & $\begin{array}{l}\text { Hold } \\
\text { Time, } \\
\mathrm{s}\end{array}$ & $\begin{array}{l}\text { Kmax, } \\
\mathrm{MPa} \mathrm{m}^{1 / 2}\end{array}$ & $\begin{array}{l}\Delta \mathrm{K}, \\
\mathrm{MPa} \mathrm{m}^{1 / 2}\end{array}$ & $\begin{array}{l}\text { CGR in } \\
\text { Env., } \\
\mathrm{m} / \mathrm{s}\end{array}$ & $\begin{array}{l}\text { CGR } \\
\text { in Air, } \\
\mathrm{m} / \mathrm{s}\end{array}$ & $\begin{array}{l}\text { Crack } \\
\text { Length, } \\
\mathrm{mm}\end{array}$ \\
\hline Start & 14.9 & & & & & & & & & & 5.899 \\
\hline $\mathrm{a}^{\mathrm{a}}$ & 18.1 & 319 & 0.34 & 0.45 & 0.45 & 0.05 & 17.3 & 11.4 & 4.09E-08 & 4.04E-08 & 6.041 \\
\hline $\mathrm{b}$ & 20 & 319 & 0.41 & 0.45 & 0.45 & 0.05 & 17.1 & 10.1 & $3.21 \mathrm{E}-08$ & $2.96 \mathrm{E}-08$ & 6.141 \\
\hline $\mathrm{c}$ & 21.6 & 319 & 0.50 & 0.43 & 0.43 & 0.07 & 15.7 & 7.8 & $1.94 \mathrm{E}-09$ & $1.43 \mathrm{E}-08$ & 6.151 \\
\hline $\mathrm{d}^{\mathrm{a}}$ & 24.3 & 319 & 0.45 & 0.44 & 0.44 & 0.06 & 16.5 & 9.1 & $2.27 \mathrm{E}-08$ & $2.16 \mathrm{E}-08$ & 6.219 \\
\hline $\mathrm{e}$ & 30.4 & 319 & 0.45 & 0.88 & 0.88 & 0.12 & 16.0 & 8.8 & $5.26 \mathrm{E}-09$ & $9.85 \mathrm{E}-09$ & 6.274 \\
\hline $\mathrm{f}$ & 39.3 & 319 & 0.50 & 1.74 & 1.74 & 0.26 & 15.9 & 8.0 & $1.80 \mathrm{E}-09$ & $3.82 \mathrm{E}-09$ & 6.304 \\
\hline $\mathrm{g}$ & 40.4 & 319 & 0.40 & 0.45 & 0.45 & 0.05 & 17.2 & 10.4 & $5.87 \mathrm{E}-08$ & $3.21 \mathrm{E}-08$ & 6.410 \\
\hline $\mathrm{h}$ & 42.4 & 319 & 0.45 & 0.44 & 0.44 & 0.06 & 16.3 & 9.0 & $1.25 \mathrm{E}-08$ & $2.13 \mathrm{E}-08$ & 6.453 \\
\hline i & 44.6 & 319 & 0.45 & 0.88 & 0.88 & 0.12 & 16.6 & 9.2 & $1.29 \mathrm{E}-08$ & $1.14 \mathrm{E}-08$ & 6.497 \\
\hline $\mathrm{j}$ & 49.0 & 319 & 0.45 & 1.75 & 1.75 & 0.25 & 16.8 & 9.2 & $9.20 \mathrm{E}-09$ & $5.84 \mathrm{E}-09$ & 6.564 \\
\hline $\mathrm{k}$ & 62.2 & 319 & 0.45 & 4.38 & 4.38 & 0.62 & 17.0 & 9.4 & $3.07 \mathrm{E}-09$ & $2.45 \mathrm{E}-09$ & 6.627 \\
\hline 1 & 74.2 & 319 & 0.46 & 8.73 & 4.37 & 1.27 & 17.2 & 9.4 & $2.37 \mathrm{E}-09$ & $1.23 \mathrm{E}-09$ & 6.686 \\
\hline $\mathrm{m}$ & 88.4 & 319 & 0.45 & 26.2 & 4.37 & 3.79 & 17.2 & 9.5 & $7.77 \mathrm{E}-10$ & $4.25 \mathrm{E}-10$ & 6.719 \\
\hline $\mathrm{n}$ & 110.6 & 319 & 0.44 & 52.5 & 10.5 & 7.52 & 17.2 & 9.7 & $6.45 \mathrm{E}-10$ & $2.24 \mathrm{E}-10$ & 6.756 \\
\hline $\mathrm{o}$ & 135.7 & 319 & 0.43 & 105.0 & 10.5 & 15.0 & 17.0 & 9.7 & $3.77 \mathrm{E}-10$ & $1.13 \mathrm{E}-10$ & 6.780 \\
\hline $\mathrm{p}$ & 184.3 & 319 & 0.43 & 262.6 & 10.5 & 37.4 & 17.3 & 9.8 & $8.72 \mathrm{E}-11$ & $4.69 \mathrm{E}-11$ & 6.795 \\
\hline$q$ & 232.7 & 319 & 0.43 & 525.9 & 10.5 & 74.1 & 17.6 & 10.0 & $1.29 \mathrm{E}-10$ & $2.49 \mathrm{E}-11$ & 6.815 \\
\hline $\mathrm{r}$ & 278.6 & 320 & 0.43 & 876.3 & 10.5 & 123.7 & 17.6 & 10.1 & $1.73 \mathrm{E}-10$ & $1.52 \mathrm{E}-11$ & 6.840 \\
\hline $\mathrm{s}$ & 326.7 & 319 & 0.48 & 865.9 & 10.4 & 134.1 & 17.6 & 9.2 & $1.27 \mathrm{E}-10$ & $1.21 \mathrm{E}-11$ & 6.860 \\
\hline 1 & 423.9 & 319 & 0.50 & 12 & 12 & 7200 & 17.6 & 8.8 & $2.33 \mathrm{E}-11$ & $1.27 \mathrm{E}-12$ & 6.875 \\
\hline $2-a$ & 575.3 & 320 & 0.50 & 12 & 12 & 7200 & 19.6 & 9.8 & $4.89 \mathrm{E}-11$ & $1.80 \mathrm{E}-12$ & 6.907 \\
\hline $2-b$ & 687.3 & 321 & 1 & - & - & - & 19.8 & - & $4.94 \mathrm{E}-12$ & - & 6.912 \\
\hline $2-c$ & 784 & 321 & 0.50 & 12 & 12 & 3600 & 19.8 & 9.9 & $4.26 \mathrm{E}-11$ & $3.73 \mathrm{E}-12$ & 6.924 \\
\hline
\end{tabular}

$\mathrm{a}$ The CGR value was obtained from the later part of the test period. 
(a)

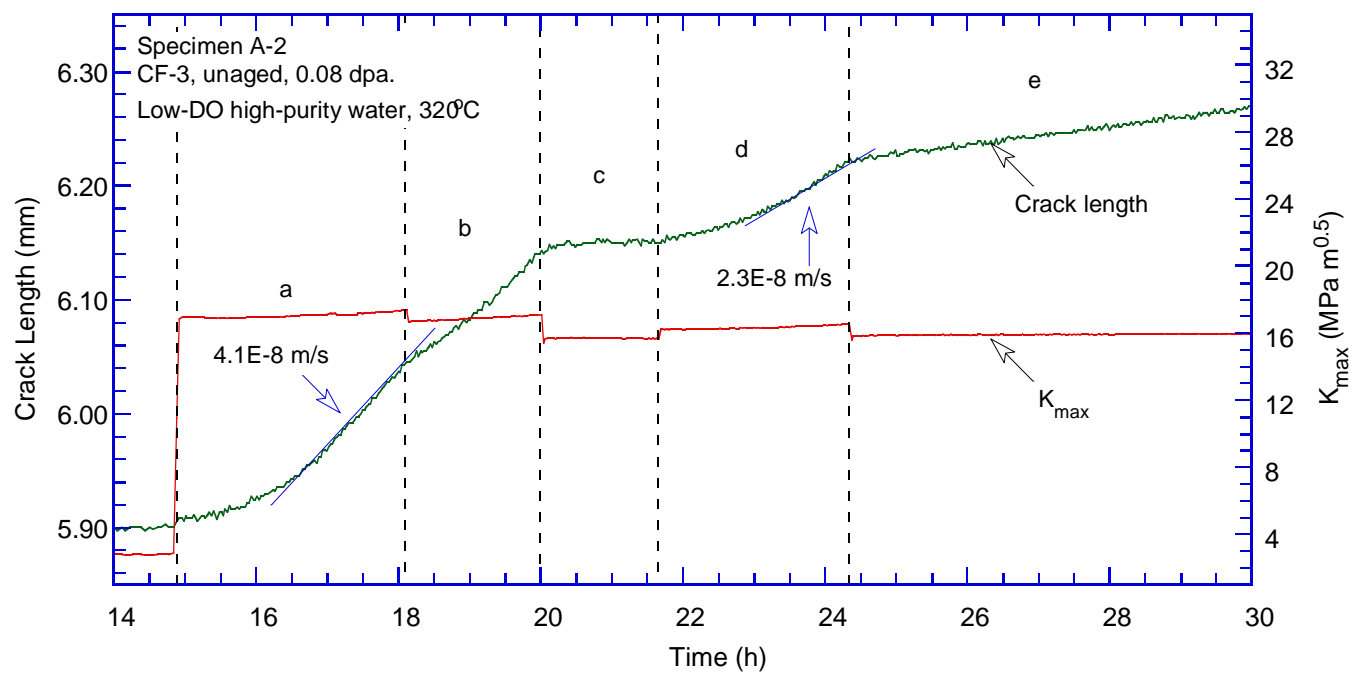

(b)

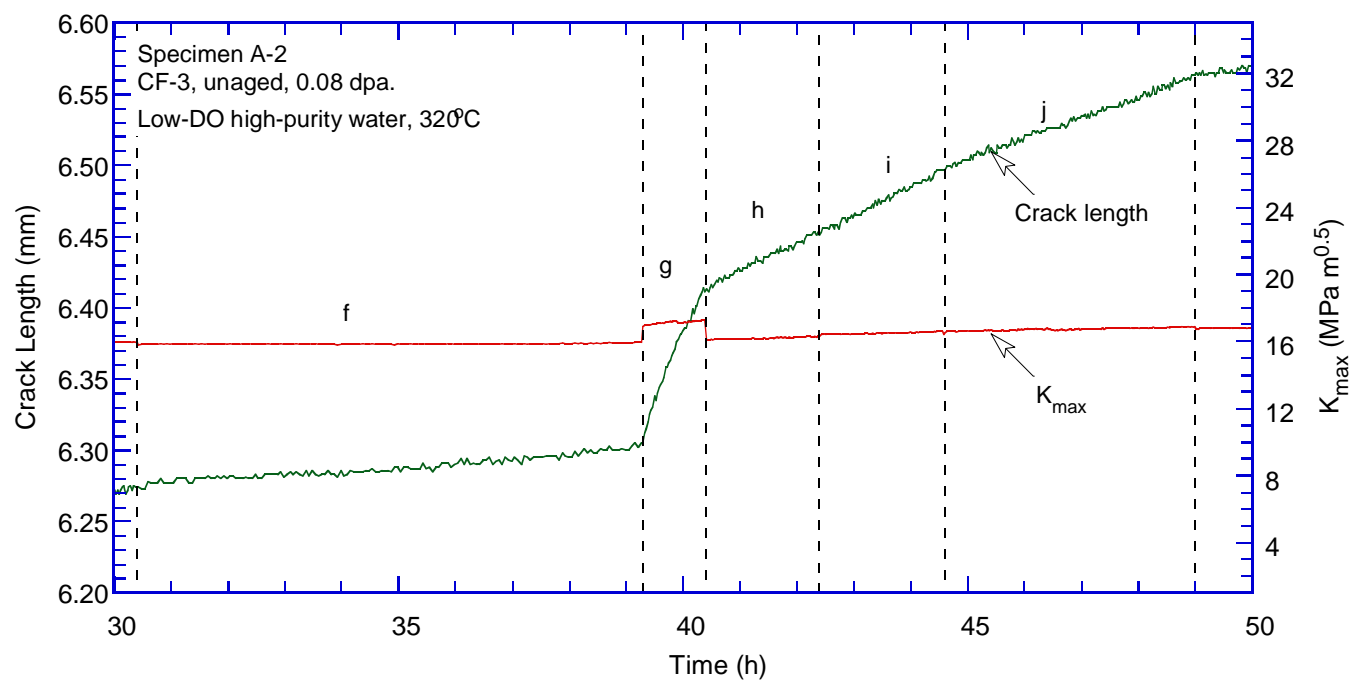

(c)

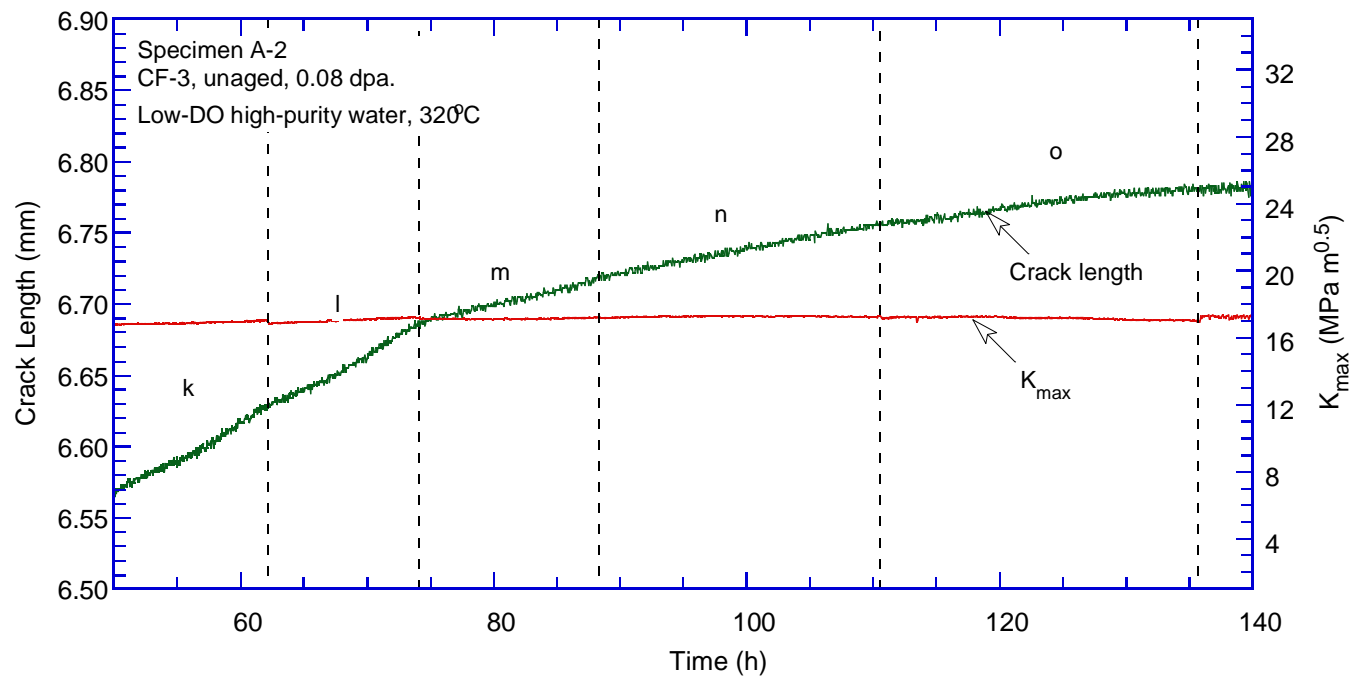

Figure 12. Crack-length-vs.-time plot for specimen A-2 (0.08-dpa unaged CF-3 with 24\% ferrite) tested in low-DO high-purity water environment: test periods (a) a-e, (b) $\mathrm{f}-\mathrm{j}$, (c) k-o, (d) p-s, and (e) 1-2. 
(d)

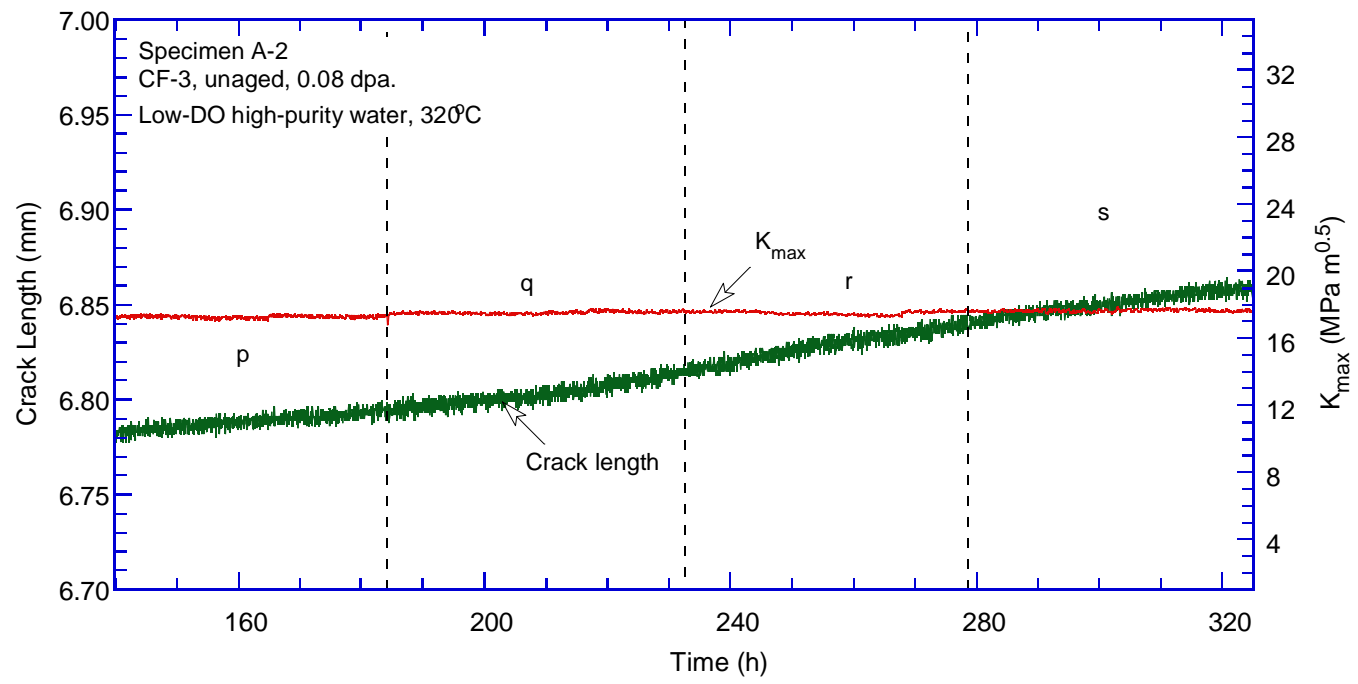

(e)

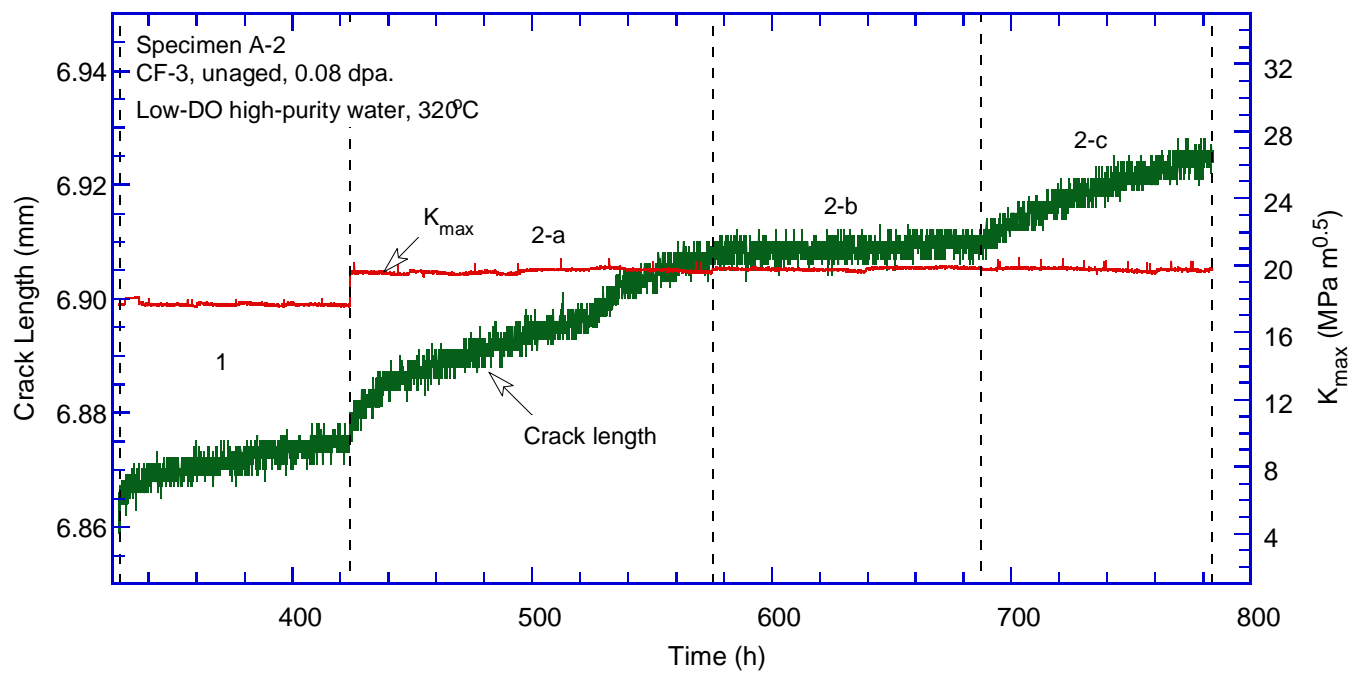

Figure 12. (Contd.) 


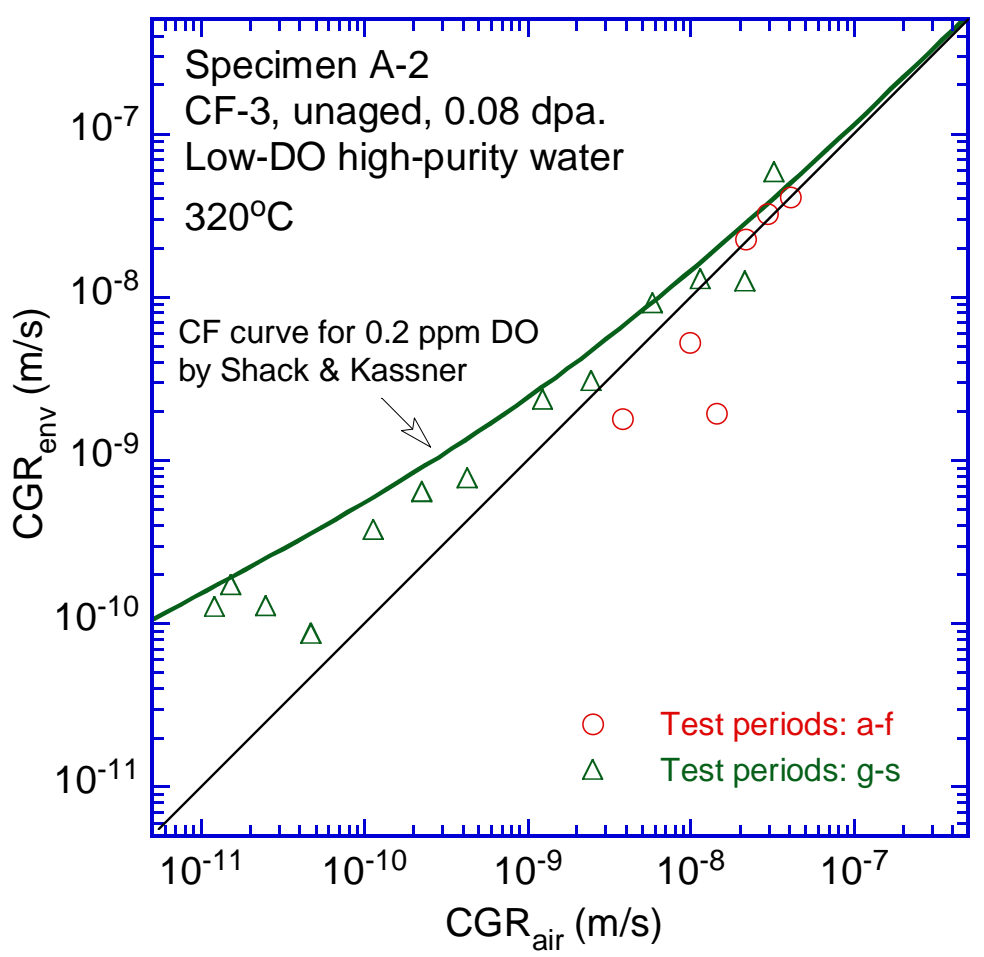

Figure 13. Cyclic CGRs of Specimen A-2.

The first constant-load test period was conducted at $17.6 \mathrm{MPa} \mathrm{m}{ }^{1 / 2}$ with PPU every $2 \mathrm{hr}$ (test period 1). After nearly $100 \mathrm{hr}$, a CGR of $2.3 \times 10^{-11} \mathrm{~m} / \mathrm{s}$ was measured over $\sim 15-\mu \mathrm{m}$ crack extension. The load was increased to $19.6 \mathrm{MPa} \mathrm{m}^{1 / 2}$ for the second constant-load test period. Again, PPU was applied every $2 \mathrm{hr}$. A CGR of 4.9x10-11 m/s was obtained over $150 \mathrm{hr}$. After the PPU was removed in test period 2-b, the measured CGR decreased one order of magnitude. Constrained by test time, only 5 - $\mu \mathrm{m}$ crack extension was accumulated for this test period. In test period 2-c, the PPU was re-introduced but with 1-hour interval. The measured CGR was nearly identical to that obtained in test period 2-a. It appears that the hold time between PPU does not affect the SCC response of CF-3 at this stress intensity level.

\section{$\underline{\text { Fracture toughness JR curve test }}$}

After the crack growth test, a fracture toughness JR curve test was conducted on this sample in the low-DO high-purity water environment. The sample was loaded at a constant extension rate of $0.43 \mu \mathrm{m} / \mathrm{s}$ while the load and load-line displacement were recorded. During the test, loading was interrupted periodically to measure the crack extension by DCPD. The obtained J and crack extension data are plotted in Fig. 14. A power-law curve fitting of the data gives a relationship of $\mathrm{J}=430 \Delta \mathrm{a}^{0.64}$. The estimated $\mathrm{J}$ value at the $0.2-\mathrm{mm}$ offset line is about $204 \mathrm{~kJ} / \mathrm{m}^{2}$. Note that the J-R curve data cannot be validated for this sample because one of the nine measurements of the final crack size was above the limit, and the $\mathrm{J}_{\max }$ requirement was omitted in this analysis. 


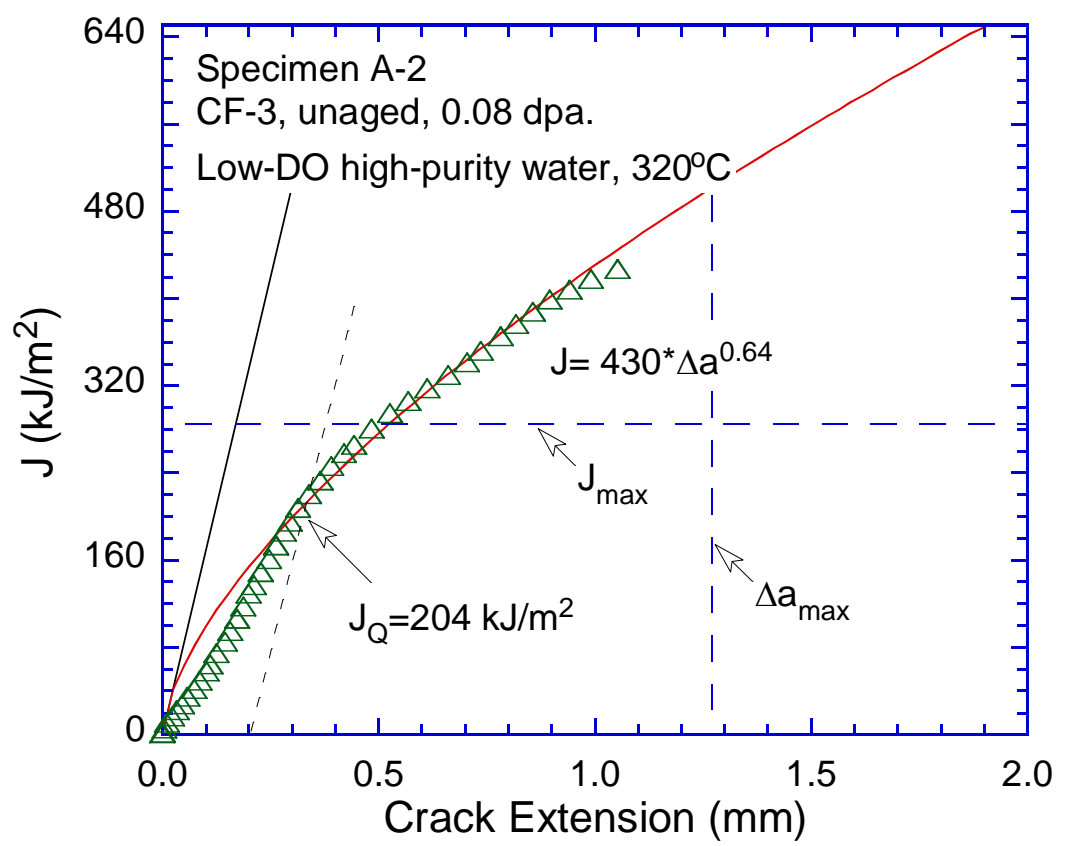

Figure 14. The J-R curve for specimen A-2.

\section{Fractographic examination}

After the JR curve test, the sample was fatigued at room temperature in an air atmosphere to break the ligament. The fracture surface was than examined with the replication technique using SEM. Figure 15 shows the entire fracture surface of specimen A-2. Note that the round smooth areas on the picture are air bubbles trapped during replication, not the original morphology of the fracture surface. Both the CGR and post-JR fatigue regions are relatively flat, clearly contrasting with the heavily deformed JR region. The crack front of the CGR test is straight, indicating a well-controlled loading condition during the CGR test. A curved crack front due to a nonconstant constraint can be seen for the JR test region.

Figure 16 shows an enlarged view of specimen A-2 along its central line. Similar to specimen A-1, which was tested in PWR water, transgranular cleavage fracture was also the dominant morphology during the CGR test. Figure 17 shows the cleavage cracking at the initial part of the CGR test, and cleavage steps resulting from brittle fracture can be seen in some places. An area of delta ferrite at the dendrite cores can be seen close to the end of the CGR test (Fig. 18). Similar to the specimen A-1 findings, less plastic deformation activities were observed in the ferrite phase. Beyond the CGR test, ductile dimples were the only fracture morphology on the fracture surface, as shown in Fig. 19. 


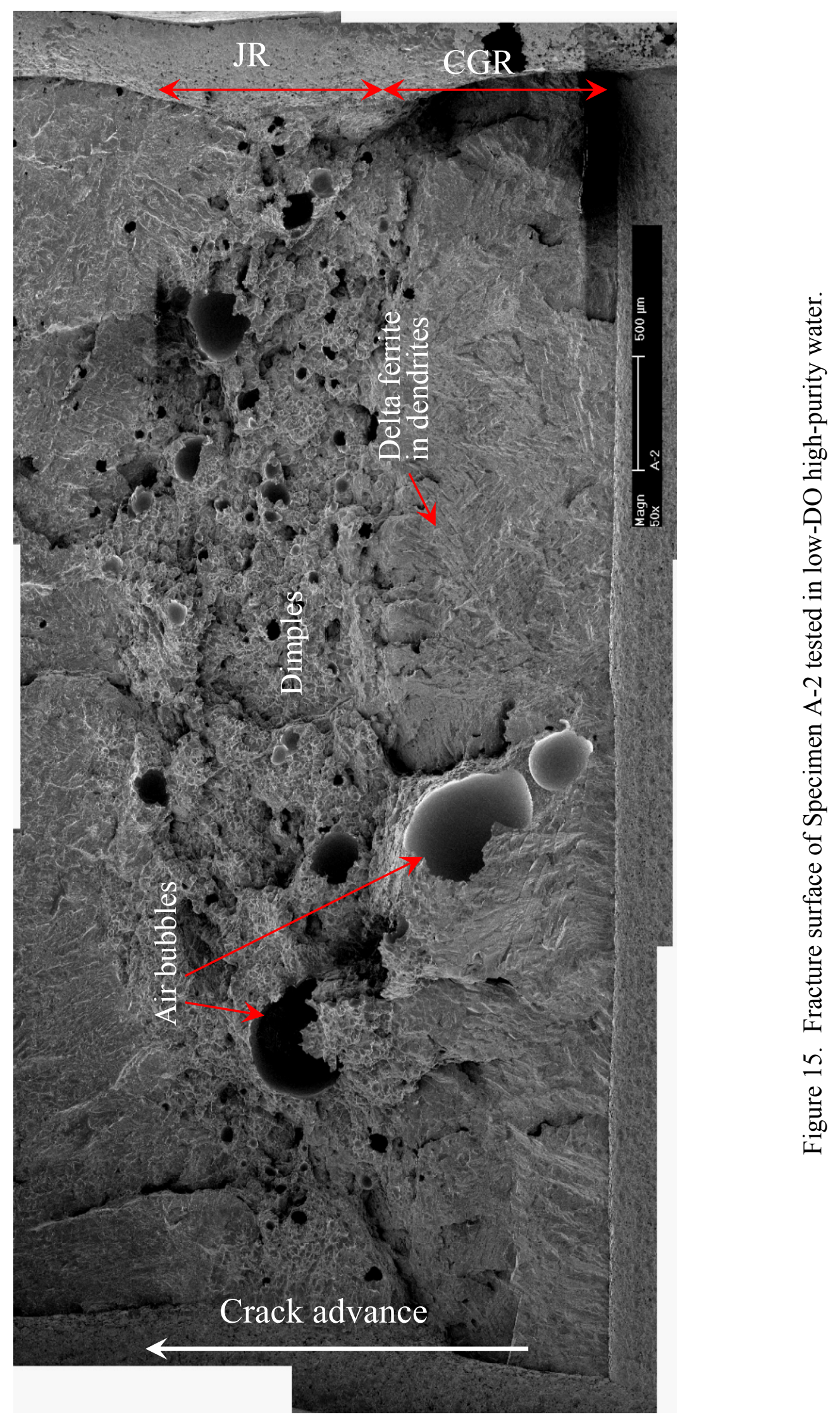




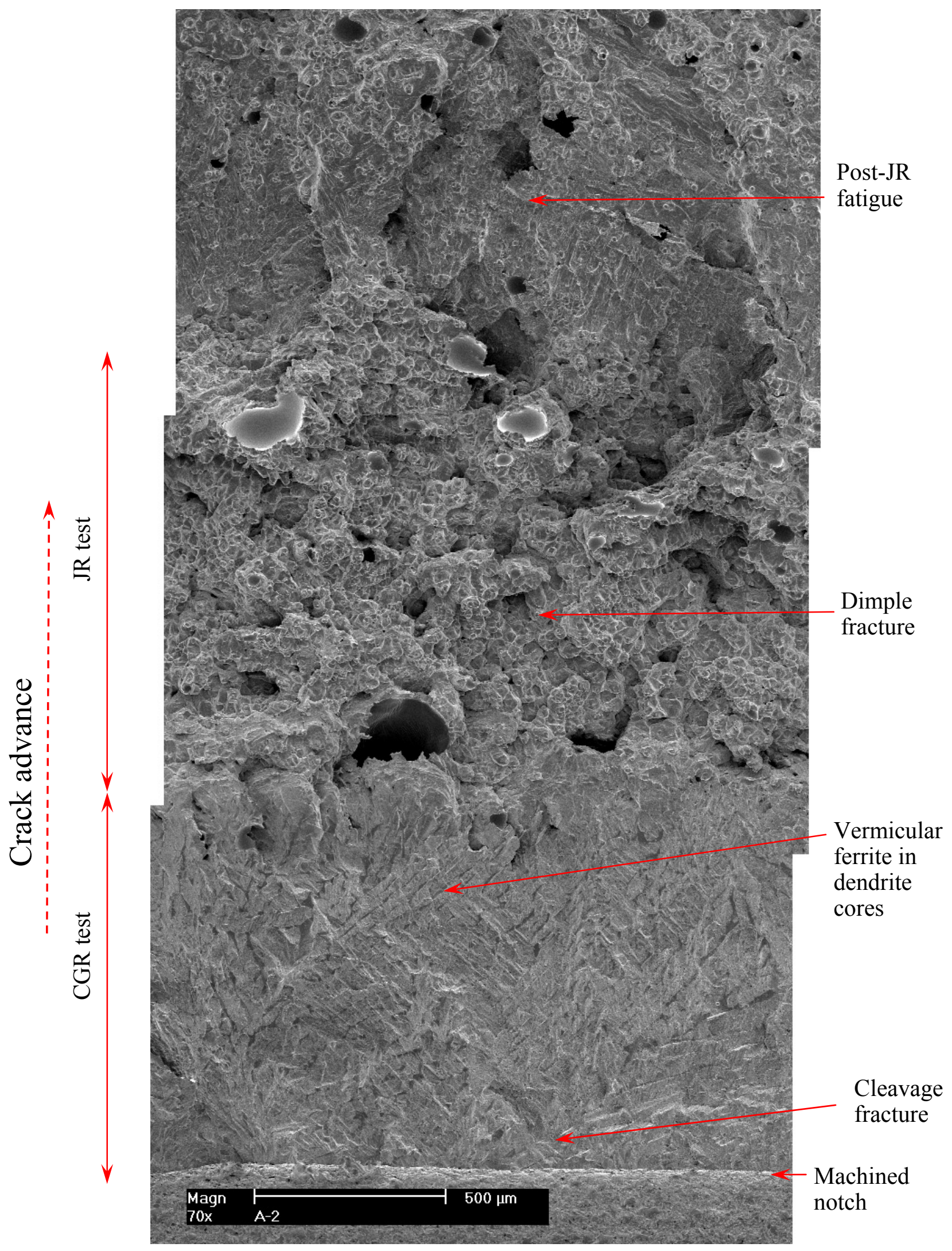

Figure 16. Fracture surface of specimen A-2 along the sample central line. 


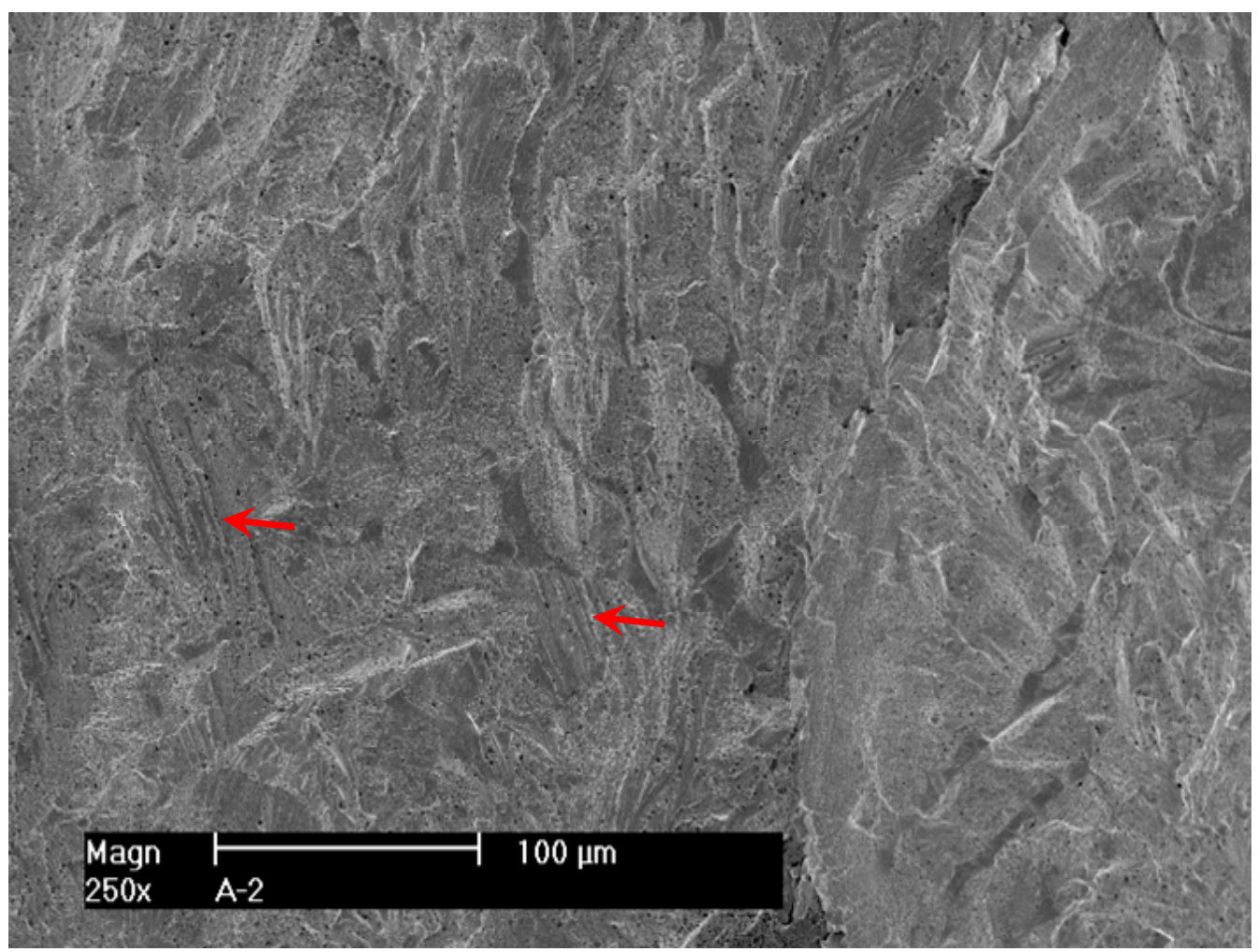

Figure 17. Cleavage steps at the beginning of CGR test of Specimen A-2. Crack propagation from bottom to top.

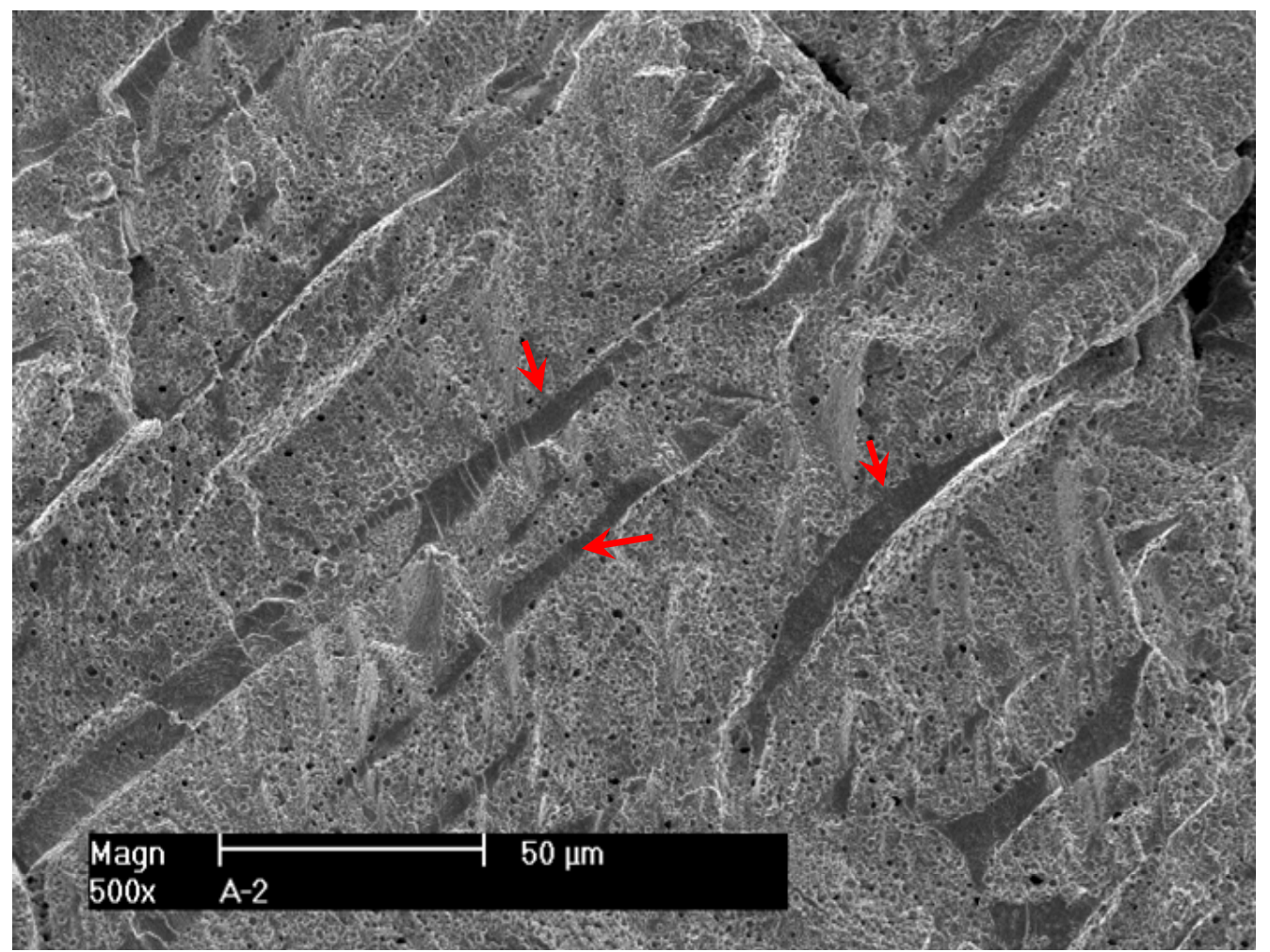

Figure 18. Fracture surface of specimen A-2 showing that ferrite deformed to a lesser extent than austenite. Crack propagation from bottom to top. 


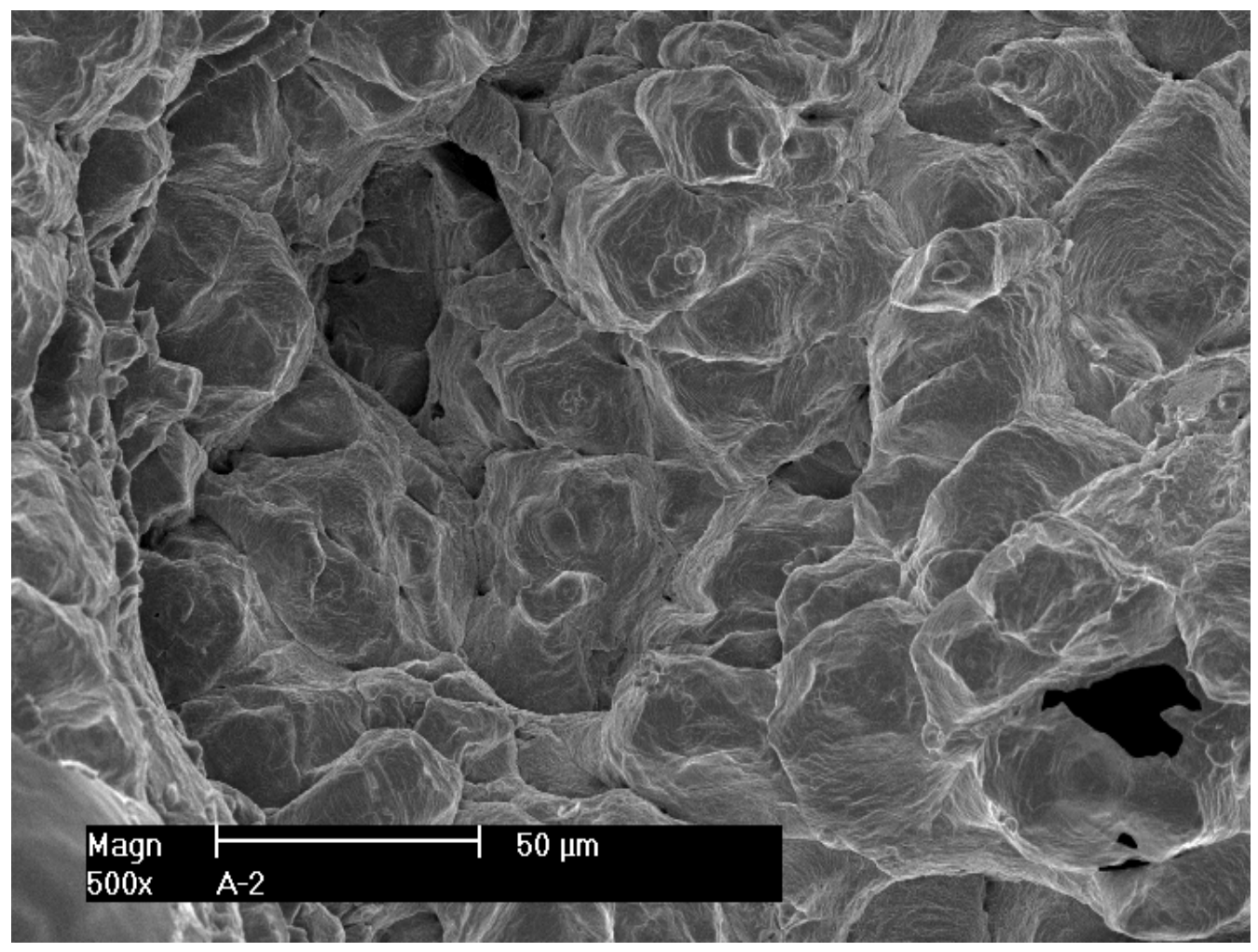

Figure 19. Ductile dimple morphology in the JR test region of specimen A-2. Crack propagation from bottom to top.

\subsubsection{Thermally Aged CF-3 SS}

\section{Crack growth rate test}

Specimen B-1 was a 0.08-dpa thermally aged CF-3 CASS with $\sim 24 \%$ ferrite. This sample was obtained from the same heat (Heat 69) as specimens A-1 and A-2. The thermal aging condition was $400^{\circ} \mathrm{C}$ and $10,000 \mathrm{hr}$. The objective was to compare the results with those of the unaged CF-3 at the same dose level. The CGR test conditions and results are summarized in Table 6, and a crack-length history plot is shown in Fig. 20.

The test was started with fatigue pre-cracking at a maximum stress intensity factor of $\sim 18 \mathrm{MPa} \mathrm{m}{ }^{1 / 2}$ and a load ratio of 0.3 . A triangular waveform was used with a frequency of $1 \mathrm{~Hz}$. Upon successful crack initiation, the maximum stress intensity factor was lowered to prepare for transitioning. In the following test periods, the load ratio and rise time were increased slowly to stimulate environmentally enhanced cracking. Despite the effort, the measured CGRs fell well below the fatigue growth rate line. A more aggressive loading condition was applied to reactivate the fatigue crack. Following that, repeated attempts (test periods $e-j, k-q$, and $r$-af) were made to induce environmental enhanced cracking. However, no elevated CGRs could be maintained. It appears that cracking cannot be sustained with a load ratio higher than 0.4 and a stress intensity factor less than $19 \mathrm{MPa} \mathrm{m}^{1 / 2}$ in this sample. Environmentally enhanced cracking 
was only observed after increasing the stress intensity factor to about $22 \mathrm{MPa} \mathrm{m}^{1 / 2}$. At this stress intensity, the measured CGR by the end of the cyclic test (period ao) was a factor of three higher than the fatigue crack growth rate in air. Subsequently, the test was set at constant load with PPU every $2 \mathrm{hr}$ in test period 1 . A CGR of $2.8 \times 10^{-11} \mathrm{~m} / \mathrm{s}$ was obtained at a stress intensity factor of $22 \mathrm{MPa} \mathrm{m}^{1 / 2}$.

Table 6. CGR test of specimen B-1 (0.08-dpa aged CF-3 with $24 \% \delta$ ferrite) in PWR water. ${ }^{\text {a }}$

\begin{tabular}{|c|c|c|c|c|c|c|c|c|c|c|c|}
\hline $\begin{array}{l}\text { Test } \\
\text { Period }\end{array}$ & $\begin{array}{l}\text { Test } \\
\text { Time, } \\
\mathrm{h}\end{array}$ & $\begin{array}{l}\text { Test } \\
\text { Temp., } \\
{ }^{\circ} \mathrm{C}\end{array}$ & $\begin{array}{l}\text { Load } \\
\text { Ratio }\end{array}$ & $\begin{array}{l}\text { Rise } \\
\text { Time, } \\
\mathrm{S}\end{array}$ & $\begin{array}{l}\text { Return } \\
\text { Time, } \\
\text { s }\end{array}$ & $\begin{array}{l}\text { Hold } \\
\text { Time, } \\
\text { s }\end{array}$ & $\begin{array}{l}\text { Kmax, } \\
\mathrm{MPa} \mathrm{m}^{1 / 2}\end{array}$ & $\begin{array}{l}\Delta \mathrm{K}, \\
\mathrm{MPa} \mathrm{m}^{1 / 2}\end{array}$ & $\begin{array}{l}\text { CGR in } \\
\text { Env., } \\
\mathrm{m} / \mathrm{s}\end{array}$ & $\begin{array}{l}\text { CGR } \\
\text { in Air, } \\
\mathrm{m} / \mathrm{s}\end{array}$ & $\begin{array}{l}\text { Crack } \\
\text { Length, } \\
\mathrm{mm}\end{array}$ \\
\hline Start & 0.52 & & & & & & & & & & 6.019 \\
\hline $\mathrm{a}$ & 3.0 & 319 & 0.27 & 0.38 & 0.38 & 0.12 & 17.6 & 12.8 & $7.88 \mathrm{E}-08$ & $6.55 \mathrm{E}-08$ & 6.250 \\
\hline $\mathrm{b}$ & 6.7 & 320 & 0.39 & 0.35 & 0.35 & 0.15 & 17.0 & 10.4 & $4.11 \mathrm{E}-08$ & $4.06 \mathrm{E}-08$ & 6.442 \\
\hline $\mathrm{c}$ & 10.5 & 320 & 0.50 & 0.64 & 0.64 & 0.36 & 15.8 & 7.9 & $2.75 \mathrm{E}-09$ & 9.97E-09 & 6.460 \\
\hline $\mathrm{d}$ & 20.1 & 320 & 0.45 & 1.32 & 1.32 & 0.68 & 15.9 & 8.8 & $3.63 \mathrm{E}-10$ & $6.50 \mathrm{E}-09$ & 6.466 \\
\hline $\mathrm{e}$ & 23.3 & 320 & 0.27 & 0.37 & 0.37 & 0.13 & 17.9 & 13.1 & 5.89E-08 & 7.29E-08 & 6.698 \\
\hline $\mathrm{f}$ & 25.4 & 320 & 0.27 & 0.36 & 0.36 & 0.14 & 17.1 & 12.4 & $4.86 \mathrm{E}-08$ & $6.25 \mathrm{E}-08$ & 6.822 \\
\hline $\mathrm{g}$ & 27.8 & 320 & 0.38 & 0.34 & 0.34 & 0.16 & 16.8 & 10.4 & 2.77E-08 & 4.22E-08 & 6.905 \\
\hline $\mathrm{h}$ & 32.2 & 320 & 0.38 & 0.66 & 0.66 & 0.34 & 16.3 & 10.1 & 8.33E-09 & $1.93 \mathrm{E}-08$ & 6.950 \\
\hline $\mathrm{i}$ & 44.2 & 319 & 0.44 & 3.20 & 3.20 & 1.80 & 16.2 & 9.2 & $2.63 \mathrm{E}-10$ & 3.07E-09 & 6.955 \\
\hline $\mathrm{j}$ & 47.5 & 320 & 0.38 & 1.32 & 1.32 & 0.68 & 16.2 & 10.0 & $7.00 \mathrm{E}-10$ & 9.49E-09 & 6.958 \\
\hline $\mathrm{k}^{\mathrm{b}}$ & 52.3 & 320 & 0.37 & 0.67 & 0.67 & 0.33 & 17.1 & 10.8 & $1.01 \mathrm{E}-08$ & 2.32E-08 & 7.000 \\
\hline 1 & 59.1 & 320 & 0.37 & 3.36 & 1.34 & 1.64 & 17.2 & 10.9 & $4.05 \mathrm{E}-09$ & 4.80E-09 & 7.048 \\
\hline $\mathrm{m}$ & 69 & 320 & 0.37 & 6.71 & 1.34 & 3.29 & 17.4 & 11.0 & 2.24E-09 & 2.48E-09 & 7.092 \\
\hline $\mathrm{n}$ & 82.8 & 320 & 0.42 & 13.0 & 3.25 & 6.99 & 17.3 & 10.1 & $3.18 \mathrm{E}-10$ & 1.01E-09 & 7.102 \\
\hline o & 95.2 & 320 & 0.36 & 13.4 & 3.35 & 6.60 & 17.3 & 11.0 & 4.09E-11 & 1.23E-09 & 7.104 \\
\hline $\mathrm{p}$ & 105 & 320 & 0.36 & 6.73 & 3.37 & 3.27 & 17.5 & 11.2 & $1.01 \mathrm{E}-10$ & 2.59E-09 & 7.107 \\
\hline$q$ & 116.8 & 320 & 0.36 & 13.6 & 3.40 & 6.41 & 17.8 & 11.5 & $9.16 \mathrm{E}-11$ & 1.40E-09 & 7.107 \\
\hline $\mathrm{r}$ & 124.2 & 320 & 0.36 & 1.36 & 1.36 & 0.64 & 18.0 & 11.5 & \begin{tabular}{|c|}
$3.85 \mathrm{E}-09$ \\
\end{tabular} & 1.43E-08 & 7.142 \\
\hline $\mathrm{s}$ & 130.6 & 320 & 0.36 & 3.39 & 1.36 & 1.61 & 18.1 & 11.6 & \begin{tabular}{|l|}
$2.66 \mathrm{E}-09$ \\
\end{tabular} & 5.86E-09 & 7.171 \\
\hline $\mathrm{t}$ & 142.5 & 320 & 0.36 & 6.77 & 1.35 & 3.23 & 18.2 & 11.7 & $1.21 \mathrm{E}-09$ & $3.00 \mathrm{E}-09$ & 7.201 \\
\hline $\mathrm{u}$ & 145.9 & 319 & 0.35 & 13.5 & 3.38 & 6.46 & 18.1 & 11.7 & $9.45 \mathrm{E}-11$ & 1.49E-09 & 7.202 \\
\hline $\mathrm{V}$ & 164.7 & 319 & 0.35 & 13.6 & 3.40 & 6.40 & 18.3 & 11.9 & $1.23 \mathrm{E}-10$ & $1.56 \mathrm{E}-09$ & 7.207 \\
\hline $\mathrm{w}$ & 170 & 319 & 0.35 & 10.2 & 3.40 & 4.80 & 18.4 & 11.9 & $1.53 \mathrm{E}-10$ & 2.09E-09 & 7.208 \\
\hline $\mathrm{x}$ & 188.7 & 319 & 0.35 & 10.2 & 3.42 & 4.75 & 18.9 & 12.3 & $1.39 \mathrm{E}-09$ & $2.28 \mathrm{E}-09$ & 7.251 \\
\hline $\mathrm{y}$ & 199 & 319 & 0.35 & 20.5 & 3.42 & 9.51 & 18.9 & 12.3 & 7.57E-10 & $1.15 \mathrm{E}-09$ & 7.265 \\
\hline $\mathrm{z}$ & 238 & 319 & 0.35 & 41.0 & 3.41 & 19.0 & 19.1 & 12.3 & $2.14 \mathrm{E}-10$ & $5.88 \mathrm{E}-10$ & 7.287 \\
\hline aa & 284.5 & 319 & 0.36 & 81.8 & 8.18 & 38.2 & 19.3 & 12.4 & $2.61 \mathrm{E}-10$ & $3.00 \mathrm{E}-10$ & 7.318 \\
\hline$a b$ & 356.3 & 319 & 0.35 & 204.4 & 8.18 & 95.6 & 19.2 & 12.4 & \begin{tabular}{|l|}
$4.36 \mathrm{E}-11$ \\
\end{tabular} & $1.20 \mathrm{E}-10$ & 7.325 \\
\hline $\mathrm{ac}$ & 442.2 & 318 & 0.35 & 413.0 & 8.26 & 187.0 & 19.9 & 12.9 & $2.88 \mathrm{E}-11$ & $6.65 \mathrm{E}-11$ & 7.331 \\
\hline $\mathrm{ad}$ & 501.5 & 319 & 0.35 & 693.0 & 8.32 & 307.0 & 20.2 & 13.2 & $1.41 \mathrm{E}-11$ & $4.26 \mathrm{E}-11$ & 7.334 \\
\hline ae & 527.8 & 318 & 0.46 & 78.0 & 7.80 & 42.0 & 19.9 & 10.8 & $5.94 \mathrm{E}-12$ & $2.23 \mathrm{E}-10$ & 7.336 \\
\hline af & 574.5 & 318 & 0.45 & 39.4 & 7.88 & 20.6 & 20.6 & 11.3 & $2.11 \mathrm{E}-10$ & $4.98 \mathrm{E}-10$ & 7.356 \\
\hline $\mathrm{ag}$ & 644.4 & 318 & 0.45 & 78.8 & 7.88 & 41.2 & 20.6 & 11.2 & negligible & $2.48 \mathrm{E}-10$ & 7.355 \\
\hline ah & 648 & 318 & 0.29 & 3.97 & 3.97 & 1.03 & 22.5 & 15.9 & 2.93E-08 & $1.30 \mathrm{E}-08$ & 7.477 \\
\hline ai & 650 & 318 & 0.34 & 11.7 & 3.89 & 3.32 & 22.3 & 14.7 & \begin{tabular}{|l|}
$7.43 \mathrm{E}-09$ \\
\end{tabular} & 3.61E-09 & 7.509 \\
\hline aj & 653.2 & 318 & 0.41 & 22.6 & 3.76 & 7.43 & 21.5 & 12.8 & \begin{tabular}{|l|}
$2.97 \mathrm{E}-09$ \\
\end{tabular} & \begin{tabular}{|l|}
$1.27 \mathrm{E}-09$ \\
\end{tabular} & 7.532 \\
\hline ak & 671.3 & 318 & 0.39 & 45.8 & 9.16 & 14.2 & 22.6 & 13.8 & $1.02 \mathrm{E}-09$ & 7.91E-10 & 7.577 \\
\hline al & 693.8 & 318 & 0.39 & 91.5 & 9.15 & 28.5 & 22.8 & 14.0 & 7.29E-10 & $4.09 \mathrm{E}-10$ & 7.618 \\
\hline $\mathrm{am}$ & 717 & 318 & 0.46 & 194.0 & 7.76 & 106.0 & 22.1 & 11.9 & $4.90 \mathrm{E}-10$ & $1.22 \mathrm{E}-10$ & 7.644 \\
\hline an & 747.7 & 319 & 0.46 & 387.7 & 7.75 & 212.3 & 22.0 & 11.9 & \begin{tabular}{|l|}
$1.66 \mathrm{E}-10$ \\
\end{tabular} & $6.16 \mathrm{E}-11$ & 7.655 \\
\hline ao & 788.7 & 319 & 0.46 & 645.4 & 7.74 & 354.6 & 22.1 & 11.9 & $1.20 \mathrm{E}-10$ & $3.71 \mathrm{E}-11$ & 7.667 \\
\hline 1 & 837.5 & 318 & 0.40 & 12 & 12 & 7200 & 22.1 & 13.3 & $2.81 \mathrm{E}-11$ & 4.42E-12 & 7.675 \\
\hline
\end{tabular}

a Simulated PWR water with $2 \mathrm{ppm} \mathrm{Li}$ and $1000 \mathrm{ppm} \mathrm{B}$. Conductivity $\sim 20 \mu \mathrm{S} / \mathrm{cm}$.

$\mathrm{b}$ The CGR value was obtained from the later part of the test period. 
(a)

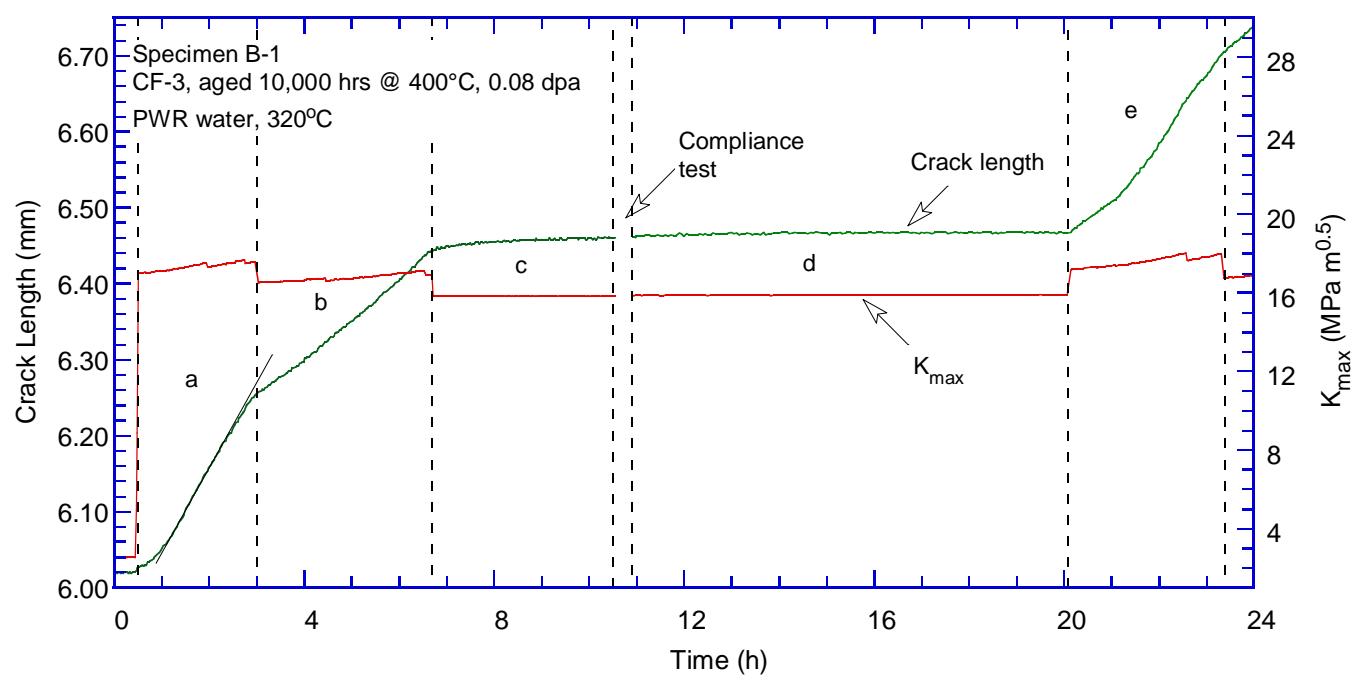

(b)

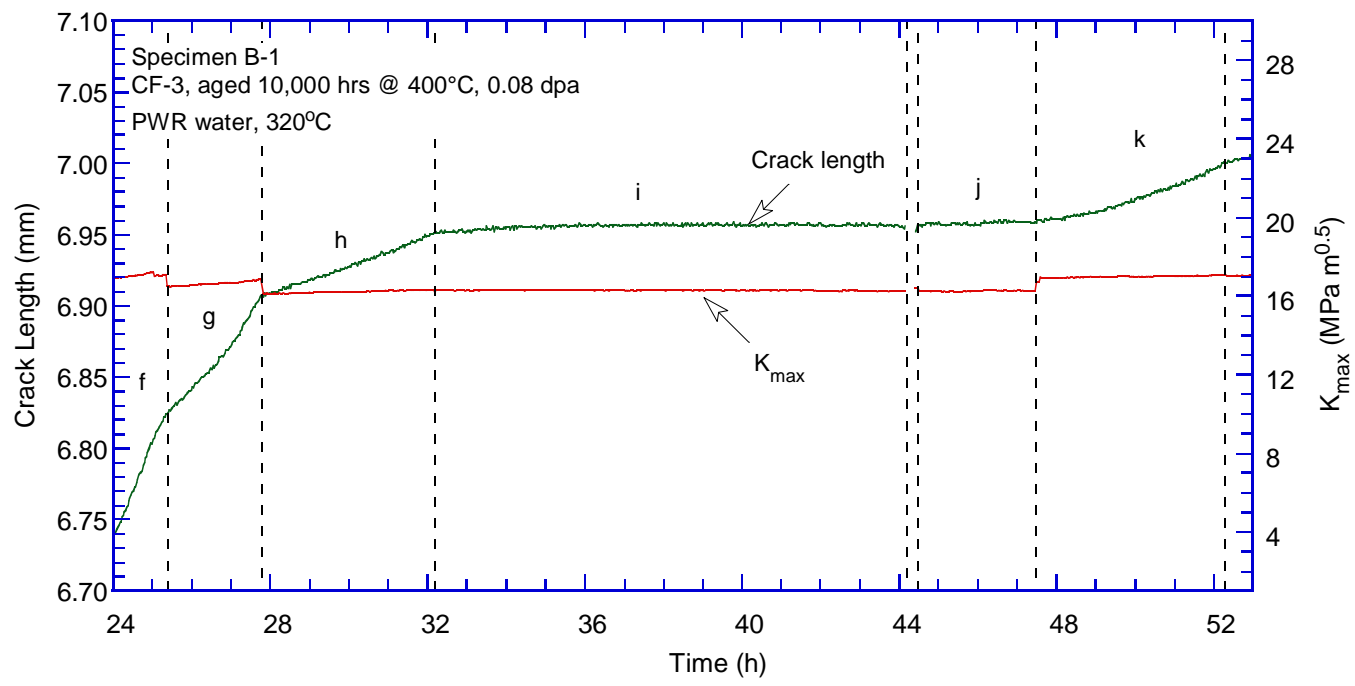

(c)

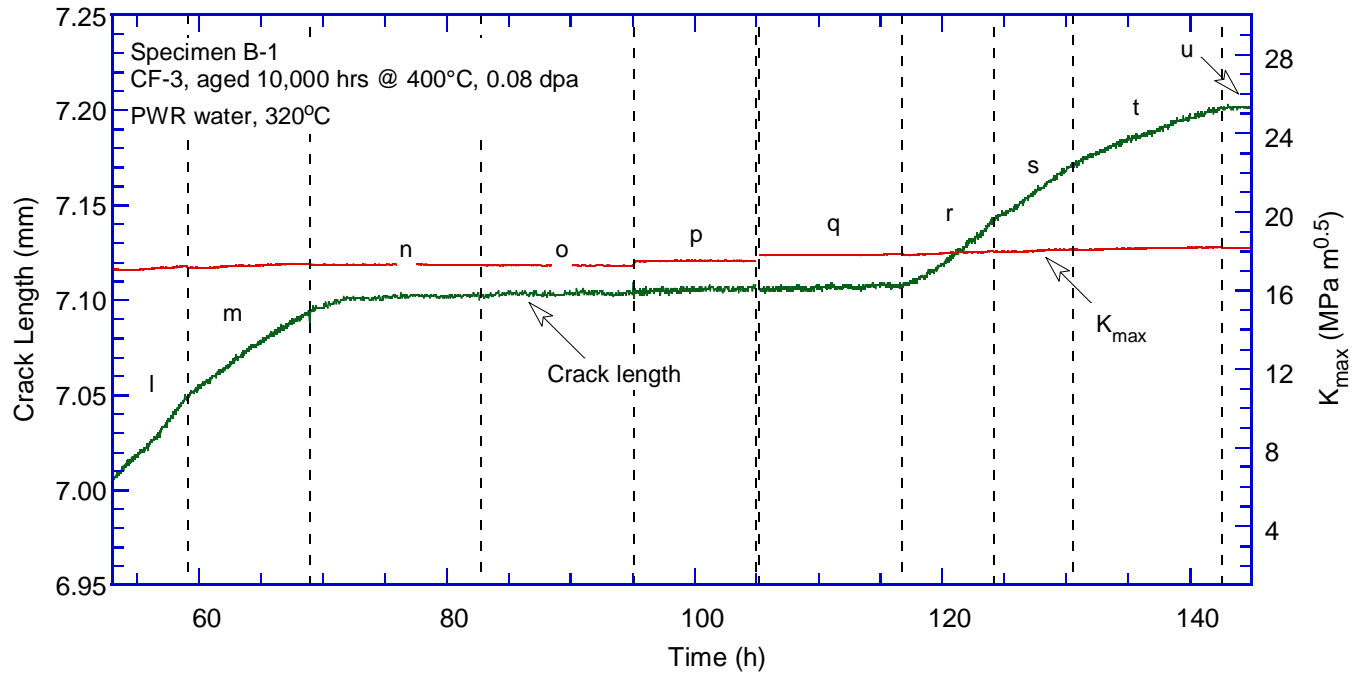

Figure 20. Crack-length-vs.-time plot for specimen B-1 (0.08-dpa aged CF-3 with 24\% ferrite) in PWR water: test periods (a) a-e, (b) f-k, (c) l-t, (d) v-y, (e) z-ac, (f) ad-ag, (h) ah-al, and $(\mathrm{g})$ am-1. 
(d)

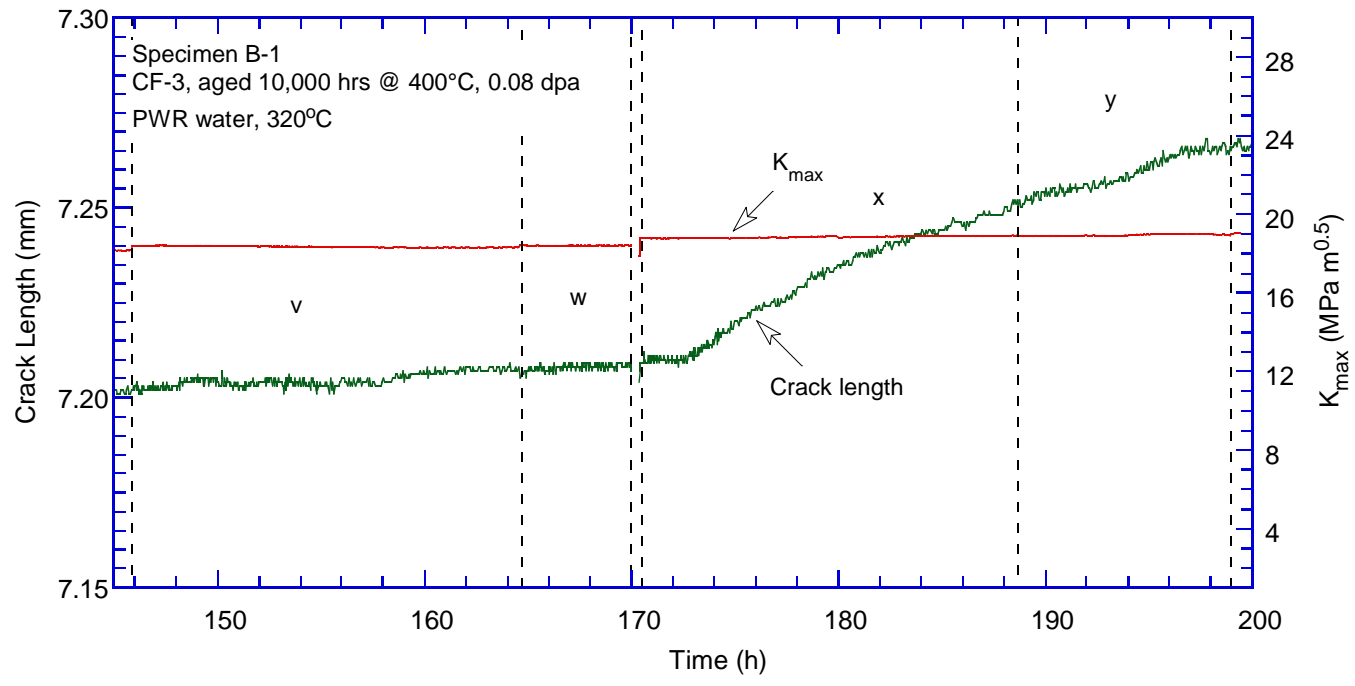

(e)

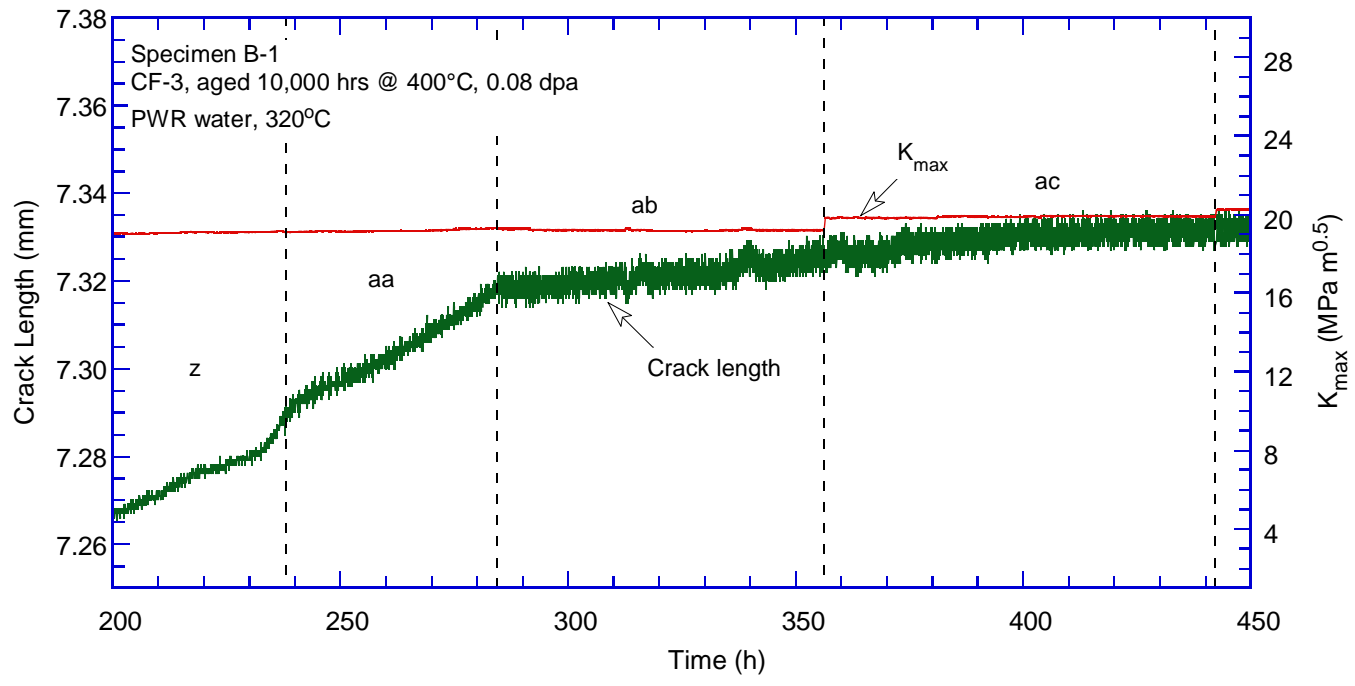

(f)

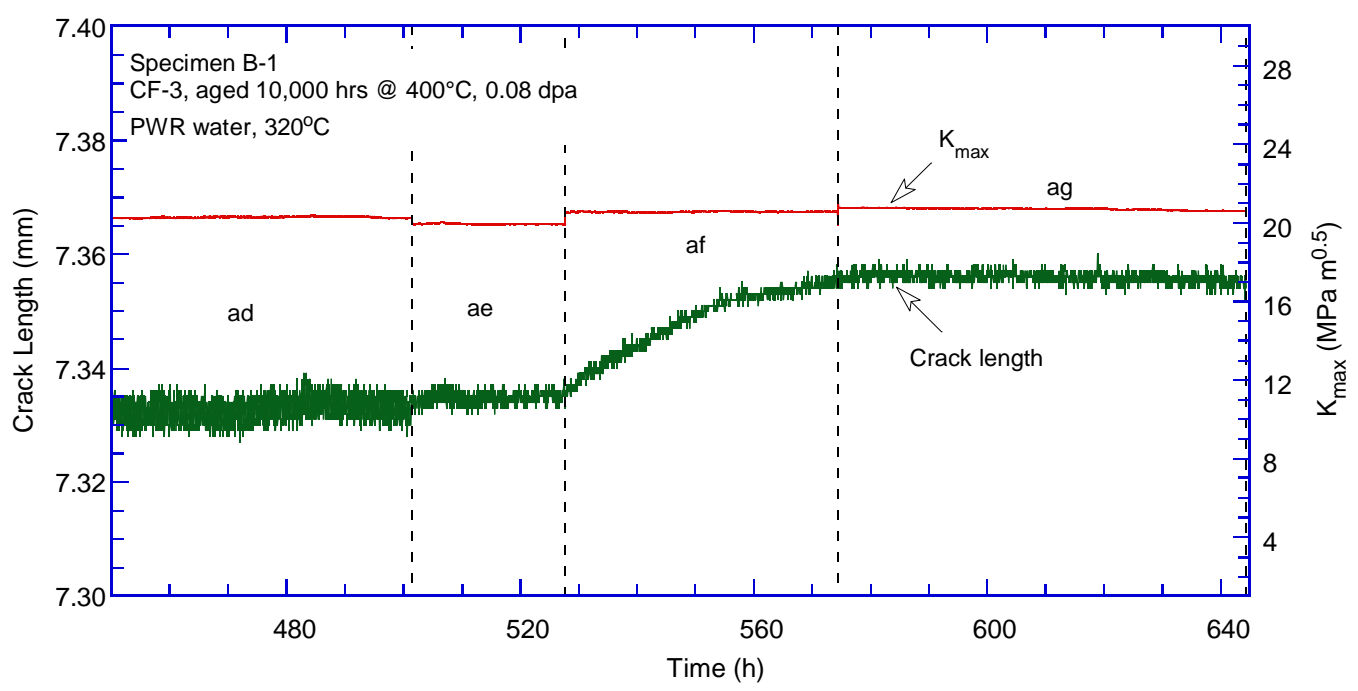

Figure 20. (Contd.) 
(g)

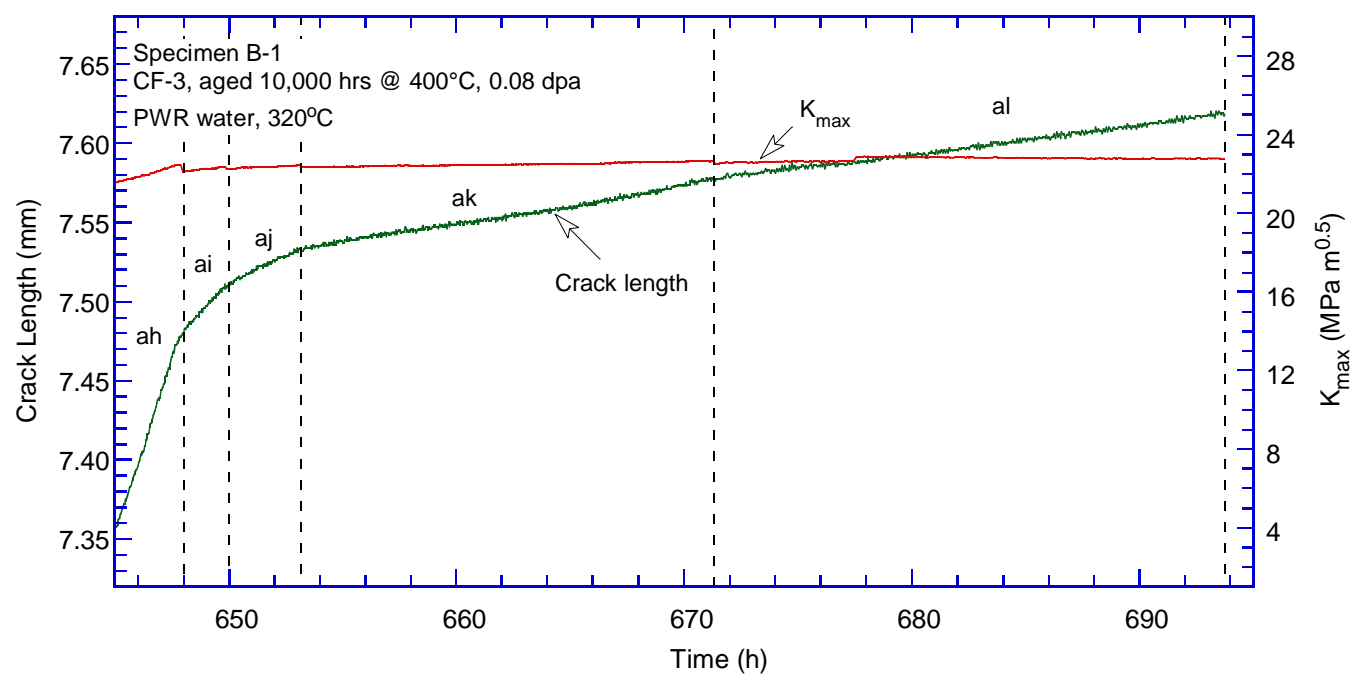

(h)

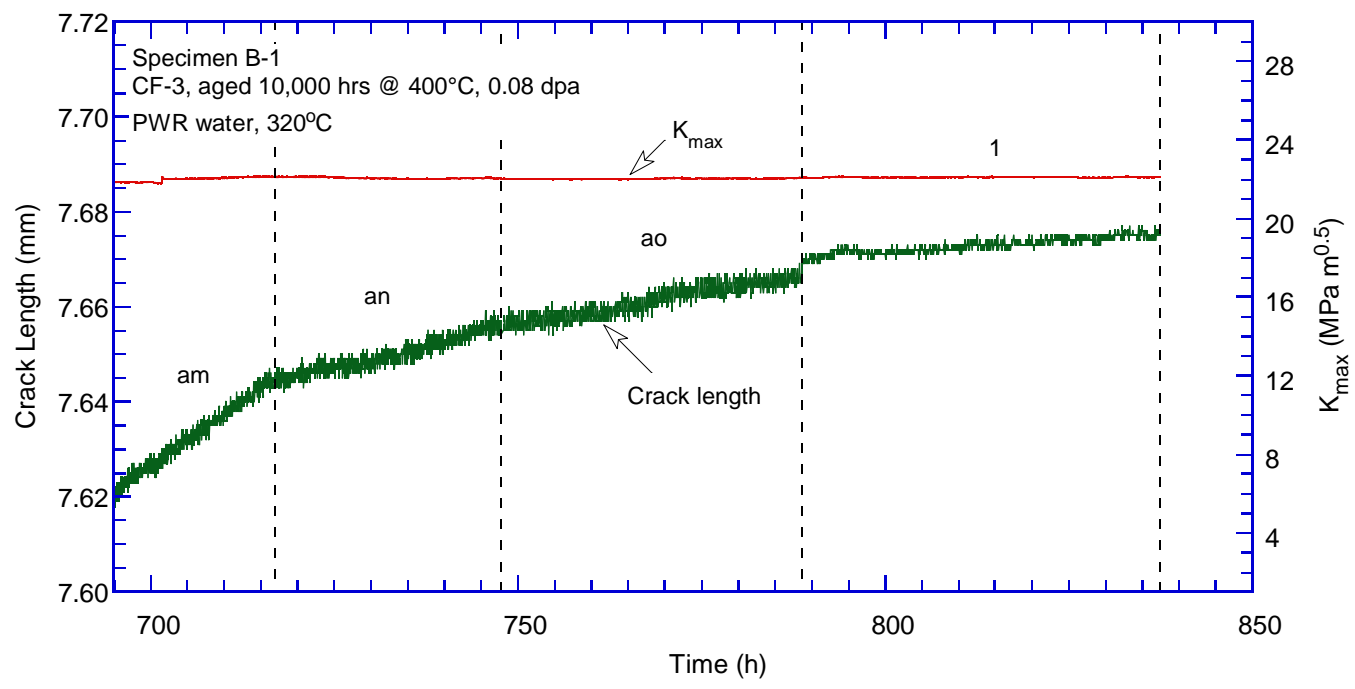

Figure 20. (Contd.)

The cyclic CGRs with a significant crack extension (defined as $>10 \mu \mathrm{m}$ ) from this sample are plotted in Fig. 21 along with the corrosion fatigue curve for unirradiated SSs. No elevated corrosion fatigue response can be seen for this material despite its thermal aging condition.

Comparing Figs. 7 and 21, we found the corrosion fatigue behaviors of unaged and aged CF-3 to be similar in PWR water. It seems that a combination of irradiation damage and thermal aging does not increase cracking susceptibility of CF-3 at $0.08 \mathrm{dpa}$, as would be expected.

All SCC CGRs obtained from specimens A-1, A-2, and B-1 are shown in Fig. 22. They are all well below the NUREG-0313 curve, as expected at this dose and ECP level. The SCC CGRs of the unaged CF-3 (specimens A-1 and A-2) are similar for the low-DO high-purity water and PWR water environments. The thermally aged specimen (B-1) has a slightly lower CGR than that of unaged CF-3. However, given the large scatter of the SCC CGR data, this difference is considered insignificant. 


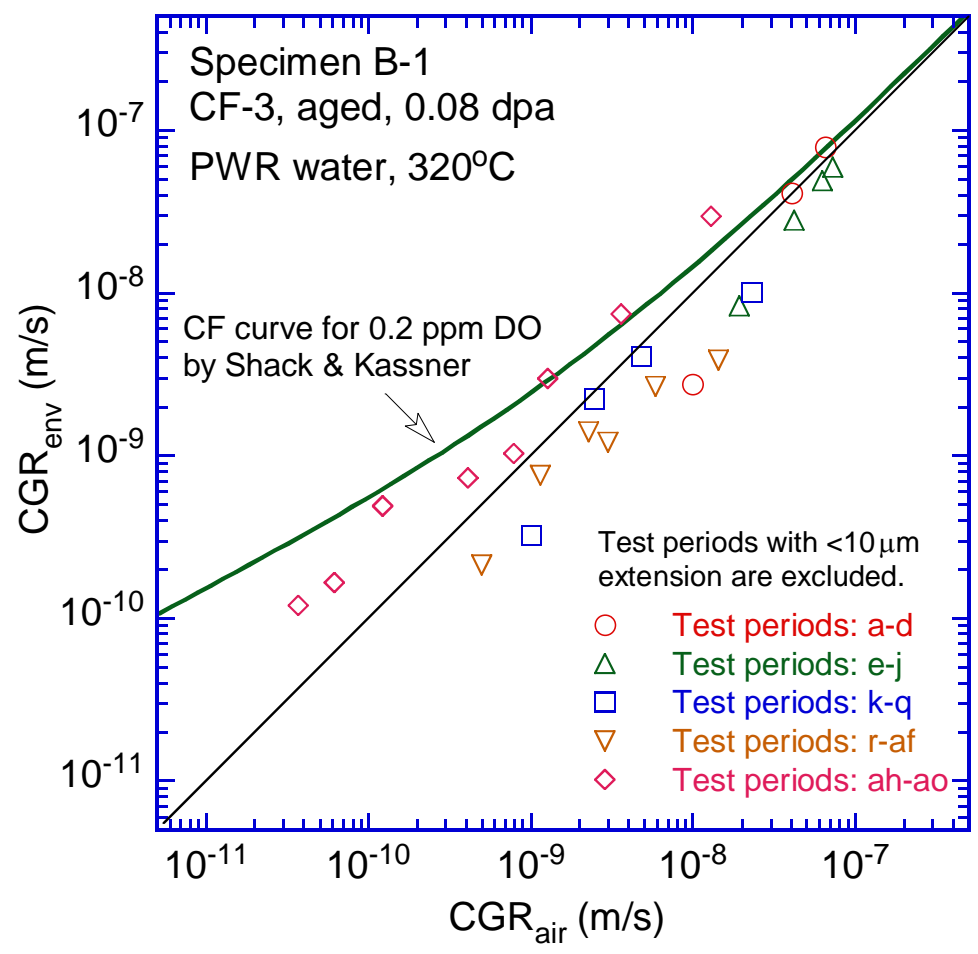

Figure 21. Cyclic CGRs of specimen B-1.

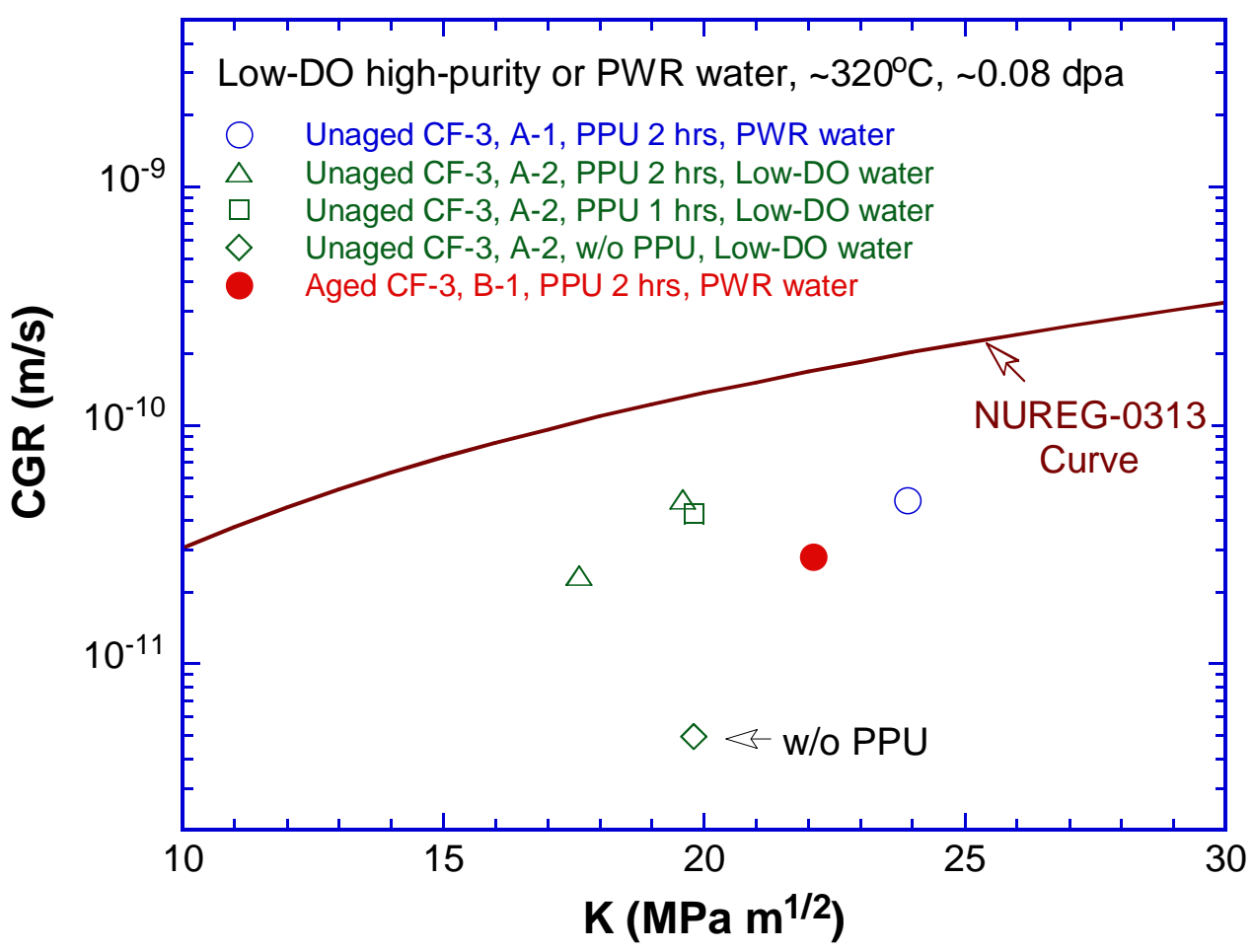

Figure 22. SCC CGRs of unaged and thermally aged CF-3 with $24 \%$ ferrite irradiated to 0.08 dpa. 


\section{Fracture toughness JR curve test}

After the CGR test, a fracture toughness JR curve test was conducted on the same sample at $320^{\circ} \mathrm{C}$ in PWR water. The obtained JR curve is shown in Fig. 23. A power-law fitting of the JR data gives a relationship of $\mathrm{J}=362 \Delta \mathrm{a}^{0.85}$. The estimated $\mathrm{J}$ value is about $116 \mathrm{~kJ} / \mathrm{m}^{2}$ at the 0.2 $\mathrm{mm}$ offset line. The J-R curve data cannot be validated with the ASTM standard because both measurements of the initial and final crack size did not meet the requirements. The data points above the $\mathrm{J}_{\max }$ limit were also used in the analysis.

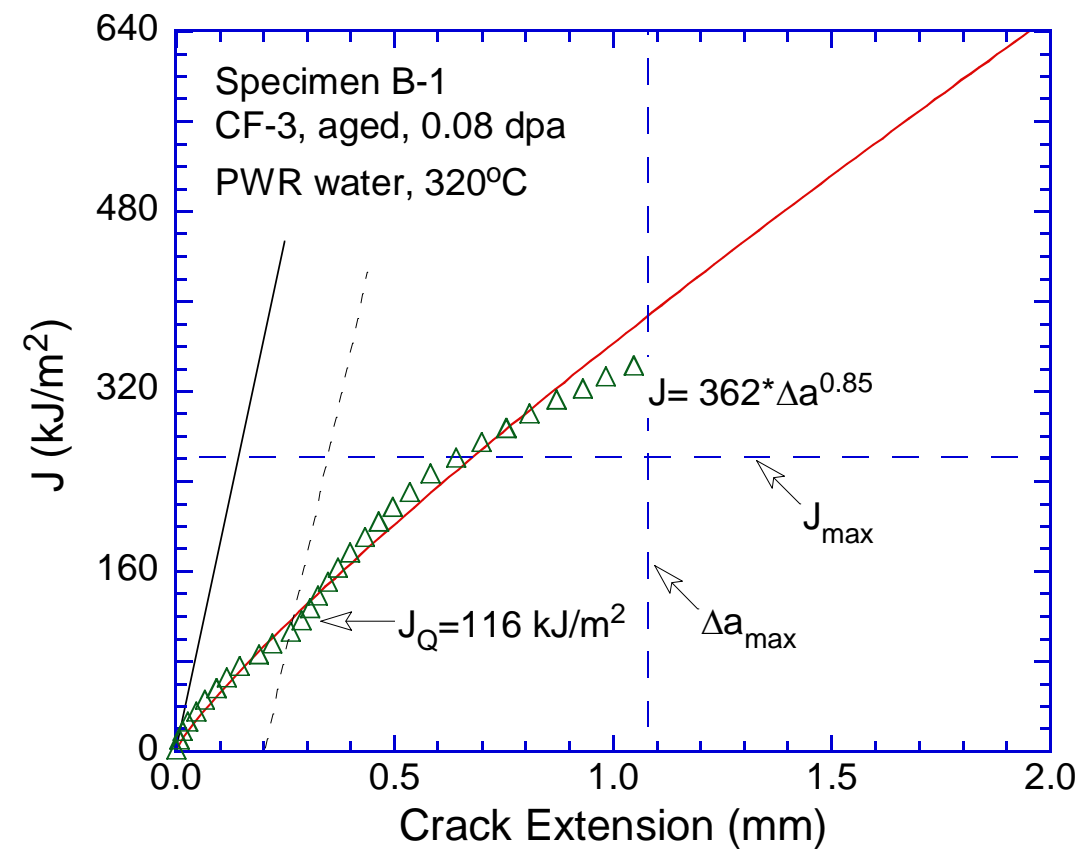

Figure 23. The J-R curve for specimen B-1.

\section{$\underline{\text { Fractographic examination }}$}

Fractographic analysis of specimen B-1 was carried out with replicas, and Fig. 24 shows the entire fracture surface. Transgranular cleavage cracking is the dominant fracture morphology in the CGR test region. The overall crack extension for CGR test is a little more on one side of the sample than the other, leading to a slightly skewed crack front. Figure 25 shows an enlarged view of the fracture surface along the sample central line. The CGR and JR test regions can be clearly distinguished by their appearance. The CGR region is relatively flat, and the JR region indicates heavily deformed ductile tearing. Note that air bubbles trapped in the replica are more excessive in the JR test region, a rough and dimpled fracture surface, than the flat CGR test region. Casting dendrite morphology with ferrite cores was seen at the end of the CGR test.

Cleavage morphology dominated the fatigue pre-cracking region, as shown in Fig. 26. Cleavage steps are clearly visible on the fracture surface. With the advance of the crack, an area with delta ferrite at dendrite cores starts to appear (Fig. 27). Compared with the surrounding austenitic phase, fewer deformation steps can be seen within the ferrite phase, as shown in Fig. 28. 


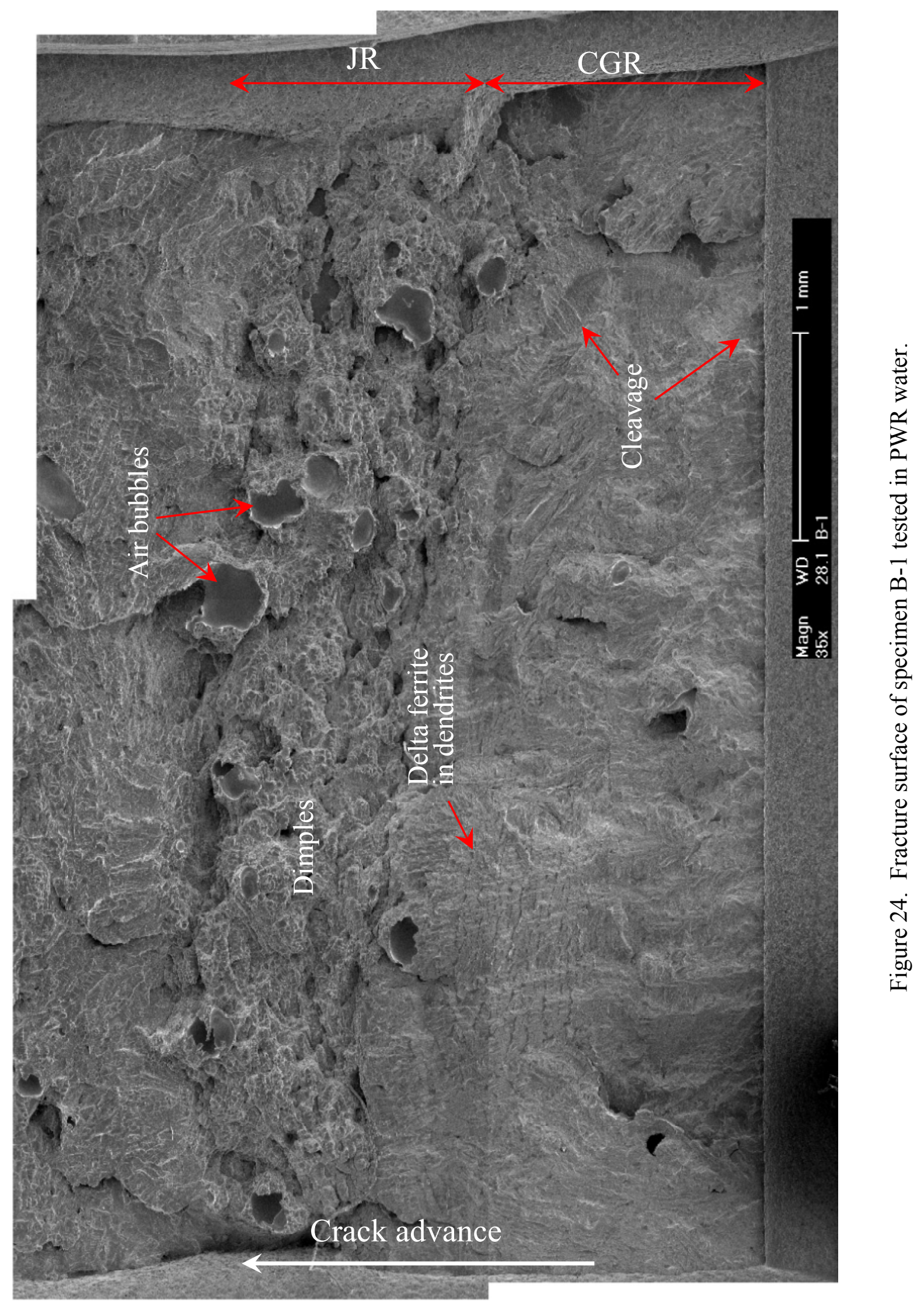




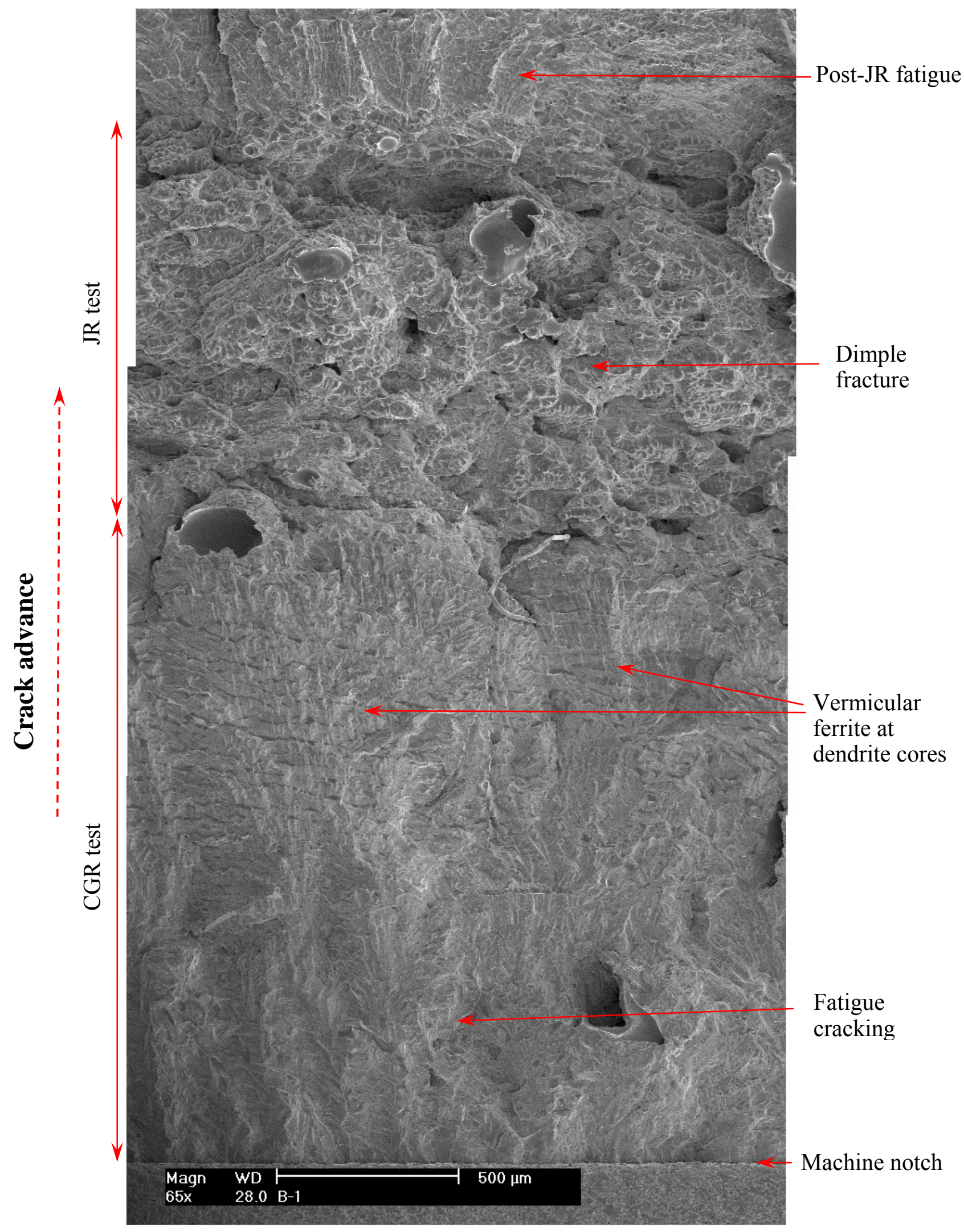

Figure 25. Fracture surface of Specimen B-1 along the sample central line. 


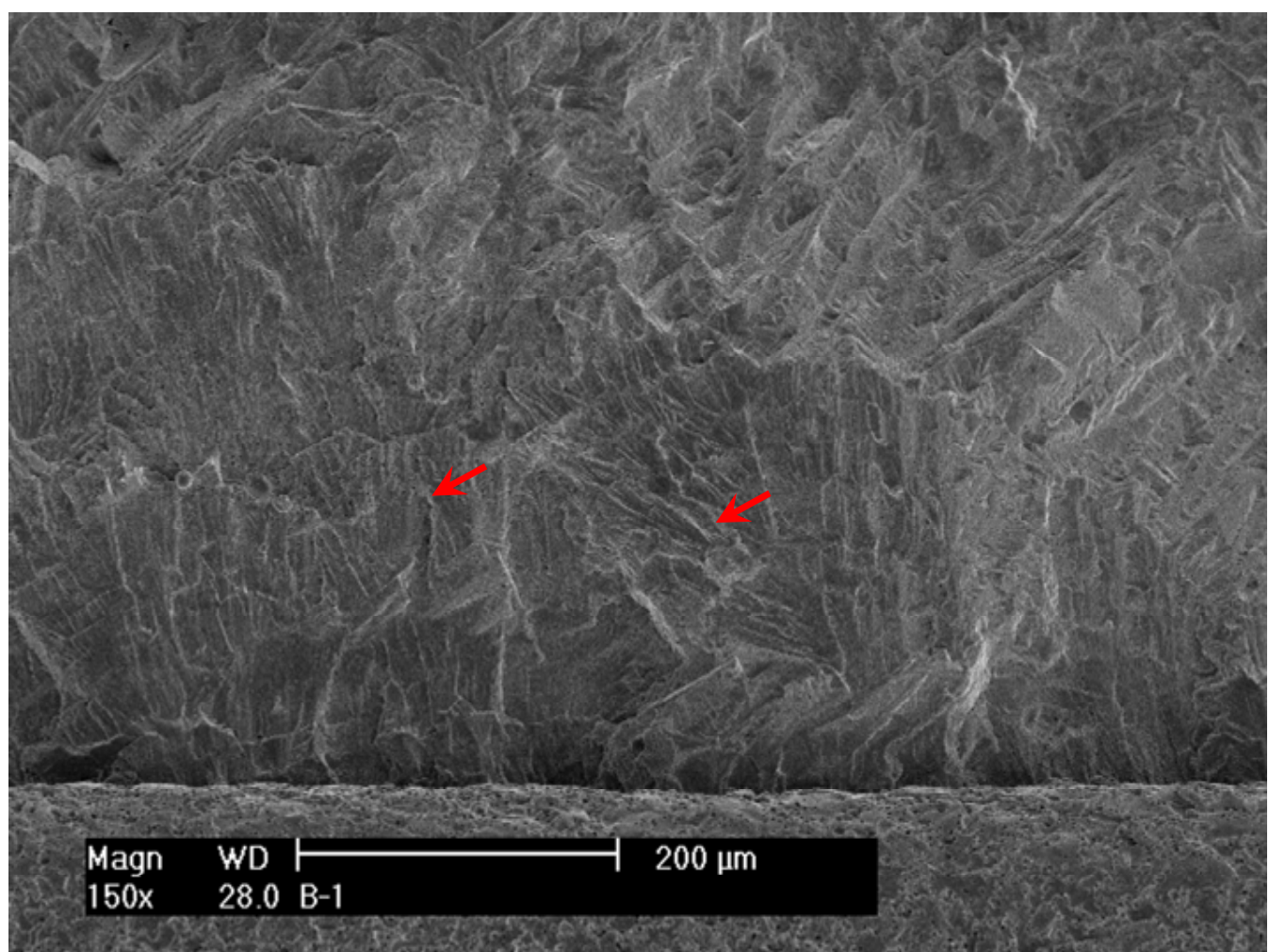

Figure 26. Cleavage steps in the pre-cracking region of specimen B-1. Crack propagation from bottom to top.

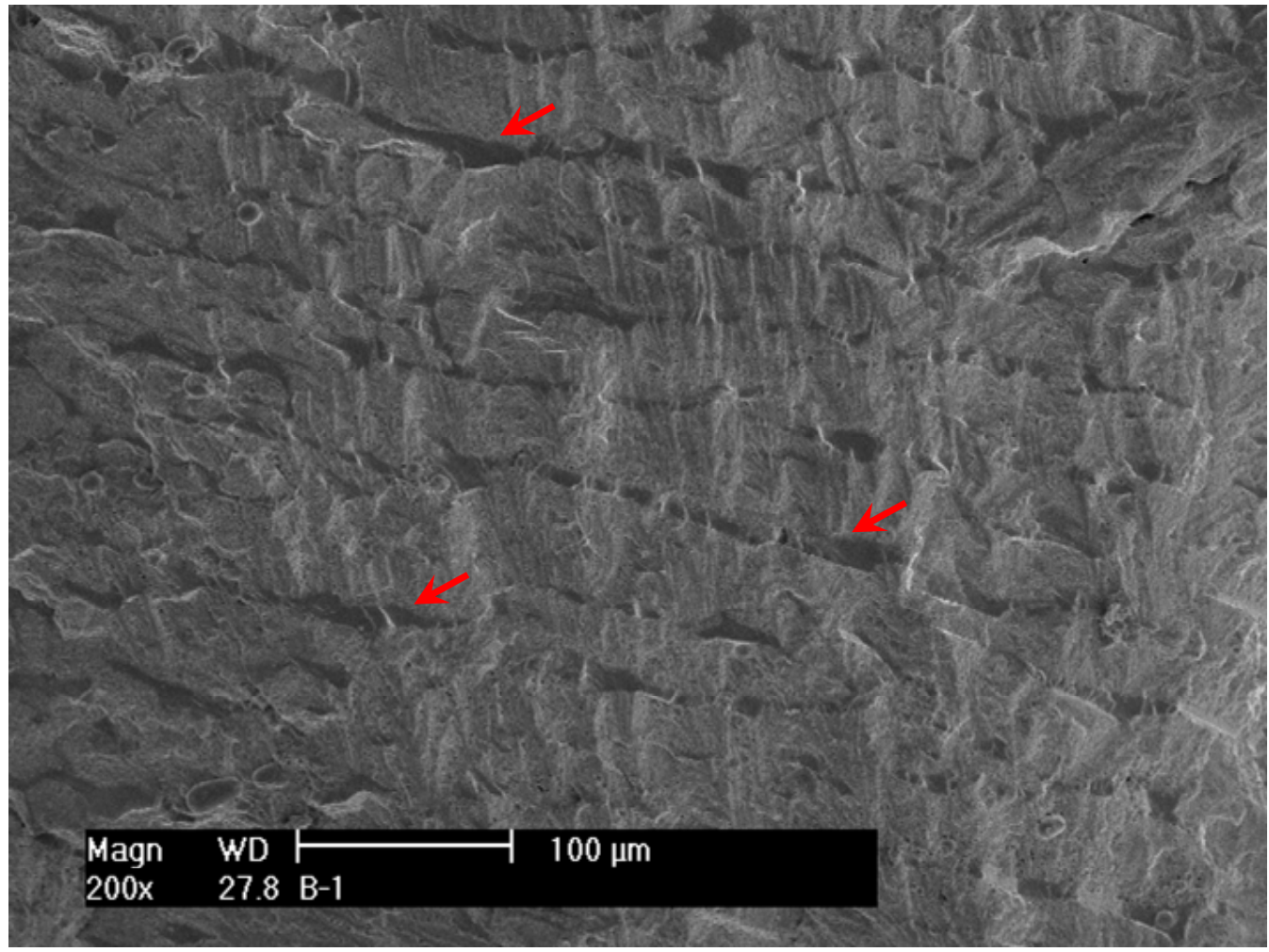

Figure 27. Delta ferrite at dendrite cores in specimen B-1. Crack propagation from bottom to top. 


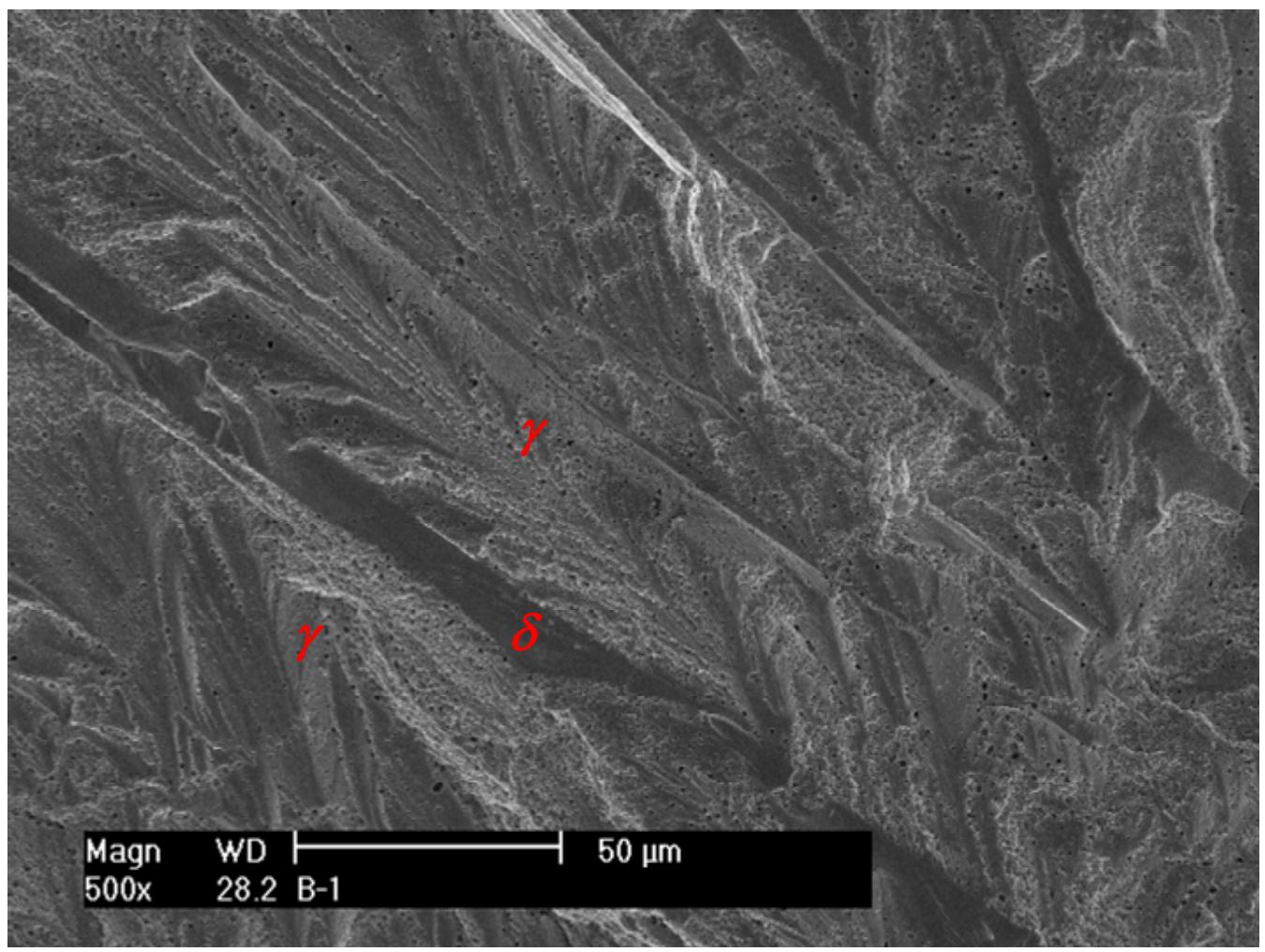

Figure 28. Fracture surface of specimen B-1 showing that delta ferrite is surrounded by heavily deformed austenite phase. Crack propagation from bottom to top.

\subsection{CF-8 Stainless Steel}

\subsubsection{Unaged CF-8 SS}

\section{Crack growth rate test}

Specimen E-1, an unaged CF-8 CASS (Heat 68) irradiated to 0.08 dpa, was tested in low-DO high-purity water at $320^{\circ} \mathrm{C}$. This sample contained $\sim 23 \%$ ferrite, similar to that of CF-3 in this study. The objective was to compare the results with those from thermally-aged CF-8 at the same dose. The CGR test conditions and results are summarized in Table 7, and a crack-length history plot is shown in Fig. 29.

Fatigue pre-cracking was started with a triangular waveform at a maximum stress intensity factor of $\sim 17.5 \mathrm{MPa} \mathrm{m}{ }^{1 / 2}$, load ratio of 0.2 , and frequency of $1 \mathrm{~Hz}$. After about $300 \mu \mathrm{m}$ crack extension, the load ratio was increased to 0.3 , and the maximum stress intensity factor was decreased to $\sim 15.5 \mathrm{MPa} \mathrm{m}{ }^{1 / 2}$. The measured CGR gradually increased in test period $c$ after a short period of sluggish growth, and the final CGR was about $2.0 \times 10^{-8} \mathrm{~m} / \mathrm{s}$. The rise time and load ratio were increased further in the subsequent test periods, and environmentally enhanced cracking started to appear at the end of test period $e$. In the following test periods, the maximum 
stress intensity factor was decreased to $\sim 14-15 \mathrm{MPa} \mathrm{m}^{1 / 2}$. Environmental enhancement appears to have been readily established in this sample at a fairly low stress intensity level with a load ratio below 0.5. By the end of test period $q$, the measured CGR was more than one order of magnitude higher than the fatigue growth rate in air. All cyclic CGRs of this sample are plotted in Fig. 30. The corrosion fatigue curve for unirradiated SSs still bounds all data points from this sample. However, compared to the cyclic CGRs of CF-3 (specimens A-1, A-2, and B-1), the CF-8 sample shows a slightly lower sensitivity to corrosion fatigue.

Table 7. CGR test of specimen E-1 (0.08-dpa unaged CF- 8 with $23 \% \delta$ ferrite) in low-DO highpurity water.

\begin{tabular}{|c|c|c|c|c|c|c|c|c|c|c|c|}
\hline $\begin{array}{l}\text { Test } \\
\text { Period }\end{array}$ & $\begin{array}{l}\text { Test } \\
\text { Time, } \\
\mathrm{h}\end{array}$ & $\begin{array}{l}\text { Test } \\
\text { Temp. } \\
{ }^{\circ} \mathrm{C}\end{array}$ & $\begin{array}{l}\text { Load } \\
\text { Ratio }\end{array}$ & $\begin{array}{l}\text { Rise } \\
\text { Time, } \\
\text { s }\end{array}$ & $\begin{array}{l}\text { Return } \\
\text { Time, } \\
\mathrm{s}\end{array}$ & $\begin{array}{l}\text { Hold } \\
\text { Time, } \\
\text { s }\end{array}$ & $\begin{array}{l}\text { Kmax, } \\
\text { MPa m}^{1 / 2}\end{array}$ & $\begin{array}{l}\Delta \mathrm{K}, \\
\mathrm{MPa} \mathrm{m}^{1 / 2}\end{array}$ & $\begin{array}{l}\text { CGR in } \\
\text { Env., } \\
\mathrm{m} / \mathrm{s}\end{array}$ & $\begin{array}{l}\text { CGR } \\
\text { in Air } \\
\mathrm{m} / \mathrm{s}\end{array}$ & $\begin{array}{l}\text { Crack } \\
\text { Length, } \\
\mathrm{mm}\end{array}$ \\
\hline Start & 1.3 & & & & & & & & & & 6.001 \\
\hline $\mathrm{a}$ & 3.0 & 320 & 0.20 & 0.44 & 0.44 & 0.06 & 17.4 & 13.9 & $6.98 \mathrm{E}-08$ & $6.70 \mathrm{E}-08$ & 6.153 \\
\hline $\mathrm{b}$ & 6.6 & 319 & 0.30 & 0.43 & 0.43 & 0.07 & 16.4 & 11.5 & $2.26 \mathrm{E}-08$ & $4.15 \mathrm{E}-08$ & 6.294 \\
\hline $\mathrm{c} 1$ & 15.6 & 319 & 0.30 & 0.85 & 0.85 & 0.15 & 15.5 & 10.8 & 4.03E-09 & $1.73 \mathrm{E}-08$ & 6.360 \\
\hline $\mathrm{c} 2$ & 18.3 & 319 & 0.30 & 0.85 & 0.85 & 0.15 & 15.7 & 11.0 & $1.57 \mathrm{E}-08$ & $1.83 \mathrm{E}-08$ & 6.421 \\
\hline c3 & 21.7 & 319 & 0.30 & 0.85 & 0.85 & 0.15 & 16.3 & 11.4 & $2.54 \mathrm{E}-08$ & $2.04 \mathrm{E}-08$ & 6.552 \\
\hline $\mathrm{d}$ & 25.3 & 319 & 0.30 & 0.84 & 0.84 & 0.16 & 15.5 & 10.9 & $1.50 \mathrm{E}-08$ & $1.76 \mathrm{E}-08$ & 6.629 \\
\hline e1 & 36.5 & 319 & 0.40 & 0.81 & 0.81 & 0.19 & 14.5 & 8.7 & $9.26 \mathrm{E}-10$ & 9.81E-09 & 6.650 \\
\hline e2 & 45.5 & 319 & 0.40 & 0.81 & 0.81 & 0.19 & 14.6 & 8.8 & 2.68E-09 & $1.01 \mathrm{E}-08$ & 6.682 \\
\hline e3 & 50.5 & 319 & 0.40 & 0.81 & 0.81 & 0.19 & 14.5 & 8.8 & $6.48 \mathrm{E}-09$ & $1.00 \mathrm{E}-08$ & 6.733 \\
\hline e4 & 53.8 & 319 & 0.40 & 0.81 & 0.81 & 0.19 & 14.9 & 8.9 & $1.59 \mathrm{E}-08$ & $1.08 \mathrm{E}-08$ & 6.805 \\
\hline $\mathrm{f}$ & 59.6 & 319 & 0.50 & 1.54 & 1.54 & 0.46 & 14.7 & 7.4 & 5.31E-09 & $3.28 \mathrm{E}-09$ & 6.852 \\
\hline $\mathrm{g}$ & 73 & 319 & 0.50 & 3.84 & 3.84 & 1.16 & 14.7 & 7.4 & 2.09E-09 & $1.32 \mathrm{E}-09$ & 6.891 \\
\hline $\mathrm{h}$ & 96.7 & 319 & 0.50 & 11.5 & 3.83 & 3.52 & 14.4 & 7.3 & $4.26 \mathrm{E}-10$ & $4.20 \mathrm{E}-10$ & 6.913 \\
\hline i & 125.1 & 320 & 0.55 & 22.4 & 3.73 & 7.62 & 14.4 & 6.5 & negligible & $1.60 \mathrm{E}-10$ & 6.911 \\
\hline $\mathrm{j}$ & 144.6 & 319 & 0.44 & 23.5 & 3.91 & 6.54 & 14.4 & 8.0 & $2.41 \mathrm{E}-10$ & $2.72 \mathrm{E}-10$ & 6.925 \\
\hline $\mathrm{k}$ & 152.2 & 320 & 0.45 & 11.8 & 3.92 & 3.25 & 14.8 & 8.2 & $1.68 \mathrm{E}-09$ & $5.76 \mathrm{E}-10$ & 6.951 \\
\hline 1 & 167.4 & 319 & 0.49 & 23.0 & 3.83 & 7.01 & 14.8 & 7.5 & $6.61 \mathrm{E}-10$ & $2.28 \mathrm{E}-10$ & 6.973 \\
\hline $\mathrm{m}$ & 181.7 & 320 & 0.49 & 46.0 & 9.19 & 14.0 & 14.7 & 7.5 & 3.64E-10 & $1.15 \mathrm{E}-10$ & 6.988 \\
\hline $\mathrm{n}$ & 217.5 & 320 & 0.49 & 92.0 & 9.20 & 28.0 & 14.7 & 7.5 & $1.97 \mathrm{E}-10$ & $5.87 \mathrm{E}-11$ & 7.004 \\
\hline 0 & 262.6 & 320 & 0.49 & 229.8 & 9.19 & 70.2 & 14.7 & 7.5 & $1.01 \mathrm{E}-10$ & $2.35 \mathrm{E}-11$ & 7.018 \\
\hline $\mathrm{p}$ & 320.5 & 320 & 0.49 & 459.7 & 9.19 & 140.3 & 14.8 & 7.6 & $1.04 \mathrm{E}-10$ & $1.20 \mathrm{E}-11$ & 7.032 \\
\hline$q$ & 360 & 321 & 0.49 & 765.3 & 9.18 & 234.7 & 14.9 & 7.6 & $8.40 \mathrm{E}-11$ & $7.20 \mathrm{E}-12$ & 7.041 \\
\hline 1 & 431.8 & 321 & 0.45 & 12 & 12 & 7200 & 14.9 & 8.2 & $1.80 \mathrm{E}-11$ & $9.53 \mathrm{E}-13$ & 7.051 \\
\hline 2 & 578.4 & 320 & 0.45 & 12 & 12 & 7200 & 16.8 & 9.3 & $2.71 \mathrm{E}-11$ & $1.43 \mathrm{E}-12$ & 7.073 \\
\hline
\end{tabular}


(a)

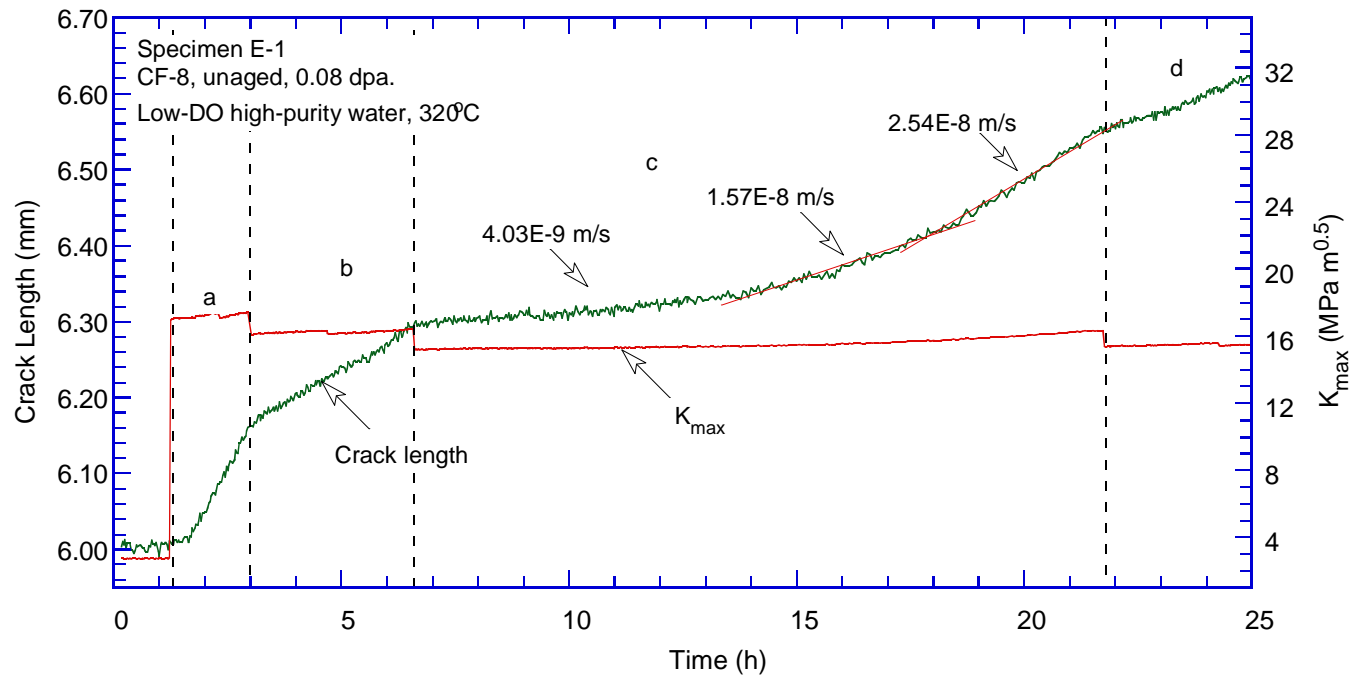

(b)

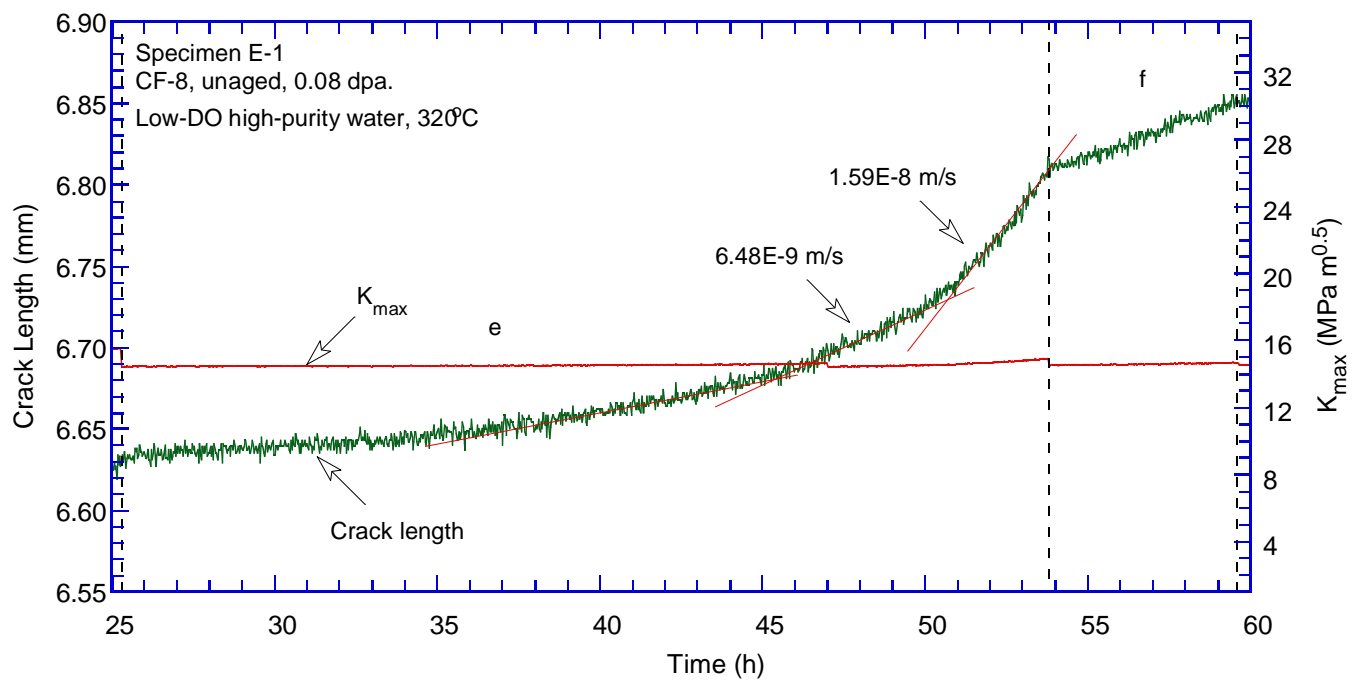

(c)

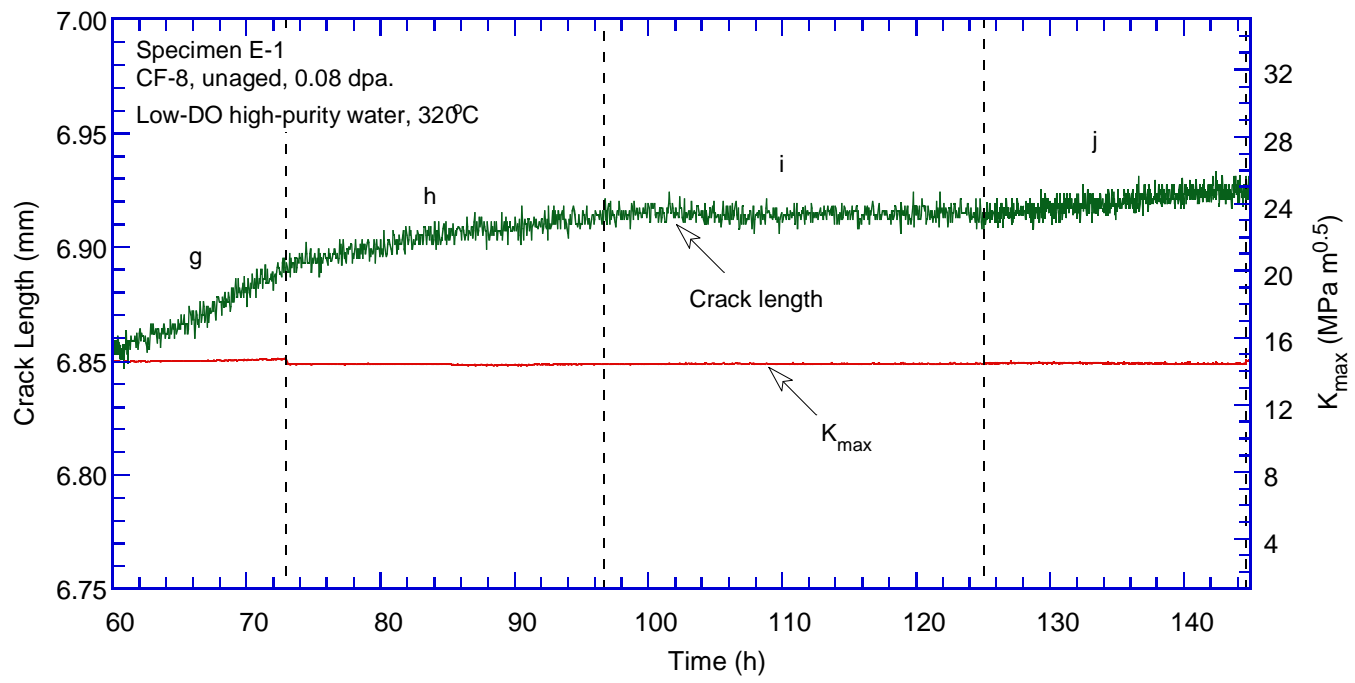

Figure 29. Crack-length-vs.-time plot for specimen E-1 (0.08-dpa unaged CF-8 with 23\% ferrite): test periods (a) a-d, (b) e-f, (c) g-j, (d) k-o, and (e) p-2. 
(d)

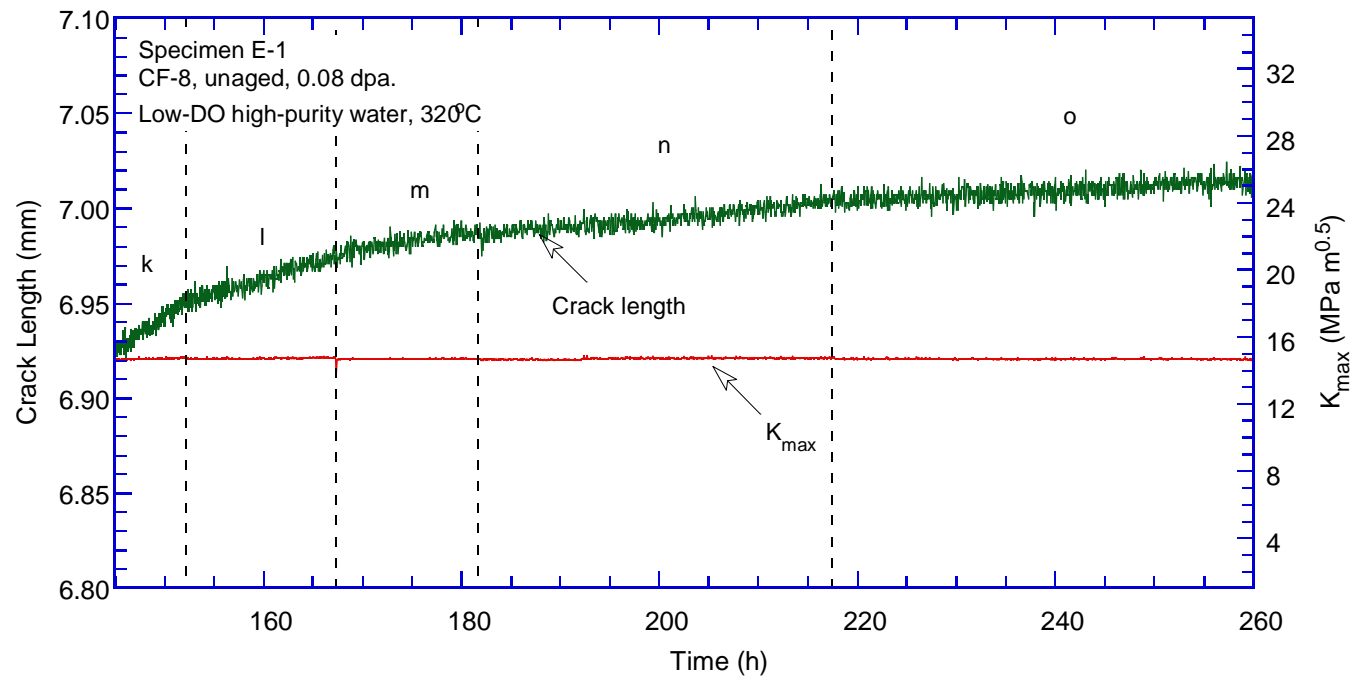

(e)

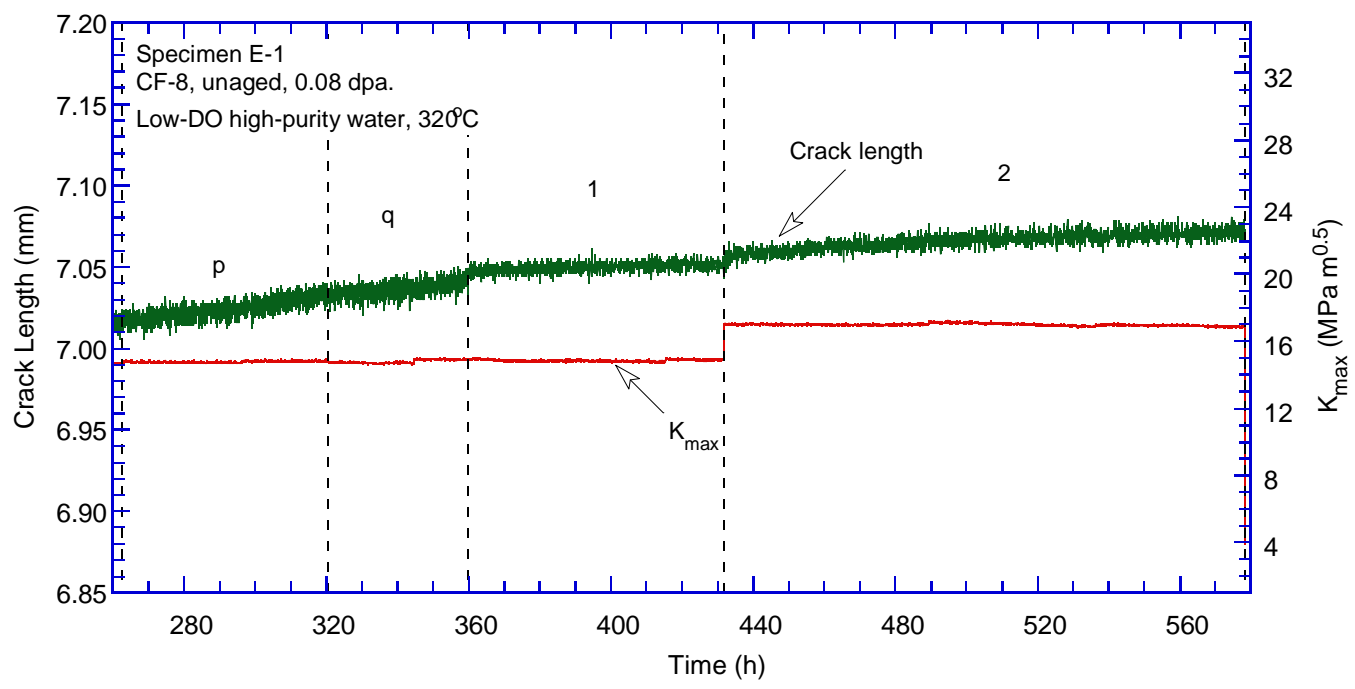

Figure 29. (Contd.) 


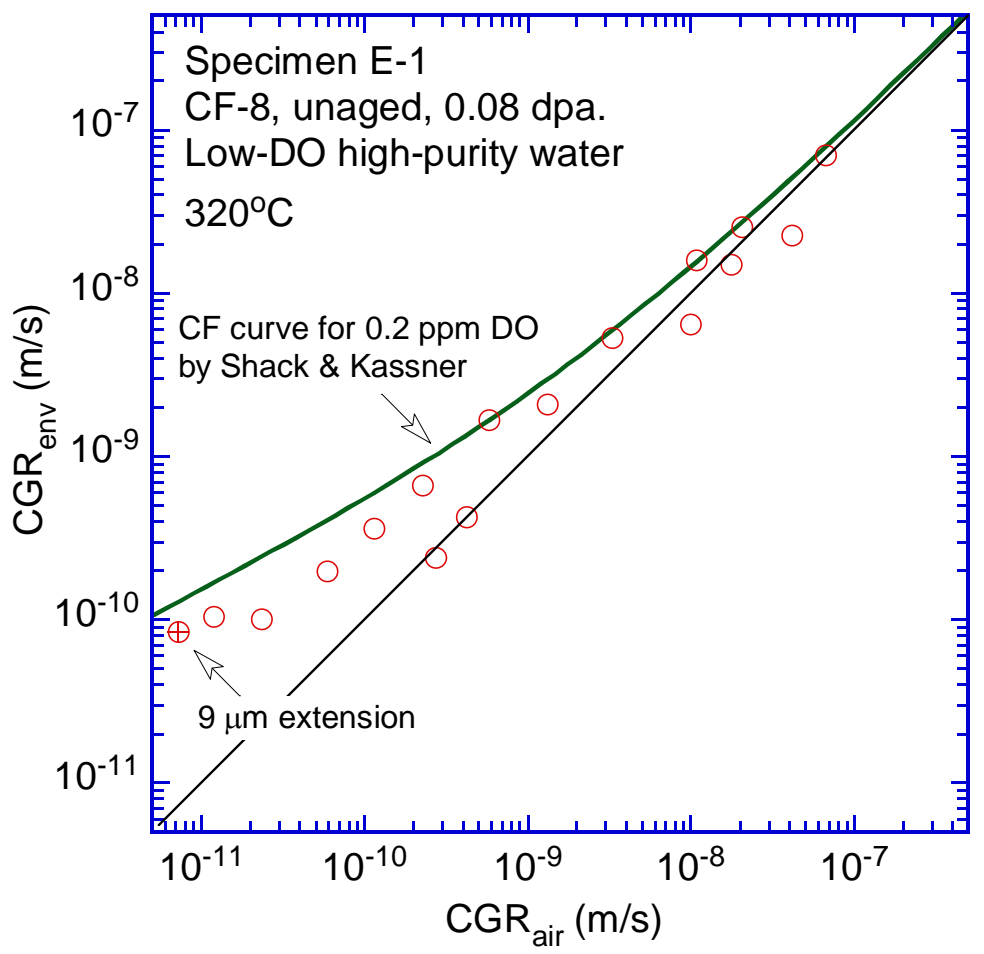

Figure 30. Cyclic CGRs of Specimen E-1.

Following the pre-cracking, the test was set at constant load with PPU every $2 \mathrm{hr}$. The stress intensity factor was about $15 \mathrm{MPa} \mathrm{m}{ }^{1 / 2}$. A SCC CGR of $1.8 \times 10^{-11} \mathrm{~m} / \mathrm{s}$ was measured over a 10$\mu \mathrm{m}$ crack extension. The stress intensity level was increased to $\sim 17 \mathrm{MPa} \mathrm{m}{ }^{1 / 2}$ with PPU every 2 $\mathrm{hr}$ for another SCC CGR measurement. A CGR of $2.7 \times 10^{-11} \mathrm{~m} / \mathrm{s}$ was recorded over $22-\mu \mathrm{m}$ crack extension.

\section{$\underline{\text { Fracture toughness JR curve test }}$}

A fracture toughness JR curve test was performed on the sample after the CGR test. The J-R data are plotted in Fig. 31, and a power-law fitting gives rise to a resistance curve of $\mathrm{J}=$ $359 \Delta \mathrm{a}^{0.57}$. The $\mathrm{J}$ value at the $0.2-\mathrm{mm}$ offset line is $183 \mathrm{~kJ} / \mathrm{m}^{2}$ for this sample. The crack extension was heavily curved in this sample, and the J-R curve data cannot be validated per the ASTM standard. Four of the nine measurements of the final crack size were above the limit, and the $\mathrm{J}_{\max }$ requirement was also ignored in the analysis. 


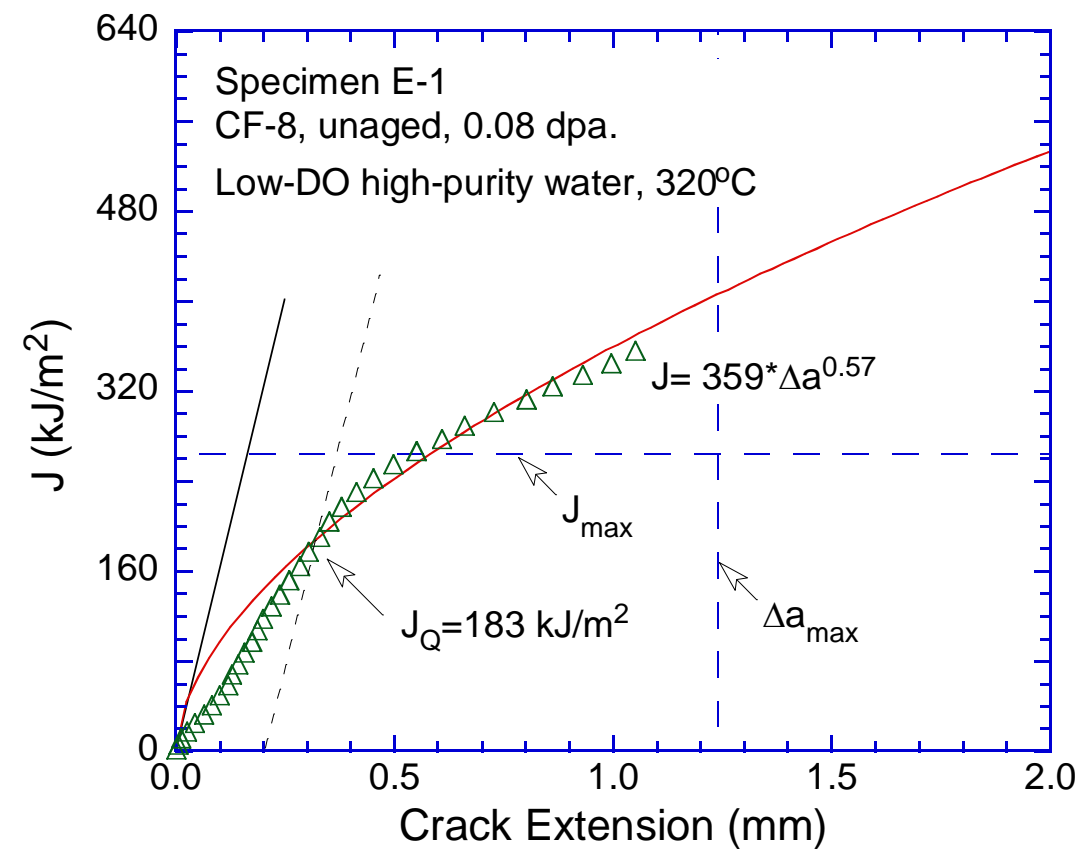

Figure 31. The JR curve of specimen E-1.

\section{$\underline{\text { Fractographic examination }}$}

Figure 32 shows the entire fracture surface of specimen E-1. Different stages of the test can be clearly identified. The CGR crack front is not straight, and the crack extension on the right side of the sample is significantly less. Transgranular cleavage cracking is the dominant morphology close to the machine notch in the pre-cracking region. As the CGR test progressed, casting microstructure became more evident. Vermicular ferrites at the cores of casting dendrites were clearly visible.

Figure 33 is an enlarged view of the fracture surface along the sample central line. Cleavage morphology dominates the fatigue pre-cracking region. Large cleavage steps can be seen in the early stage of the test (Fig. 34). With the advance of the crack, the fracture surface became smoother, and cleavage steps less pronounced. As shown in Fig. 35, deformation steps can still be seen in the austenite but are much less evident in the ferrite. At the end of the CGR test, the fracture surface became completely flat in both the ferrite and austenite (Fig. 36). Beyond the CGR test region, the fracture morphology changed to ductile dimples (Fig. 37), suggesting a heavy plastic deformation leading to a ductile fracture. 


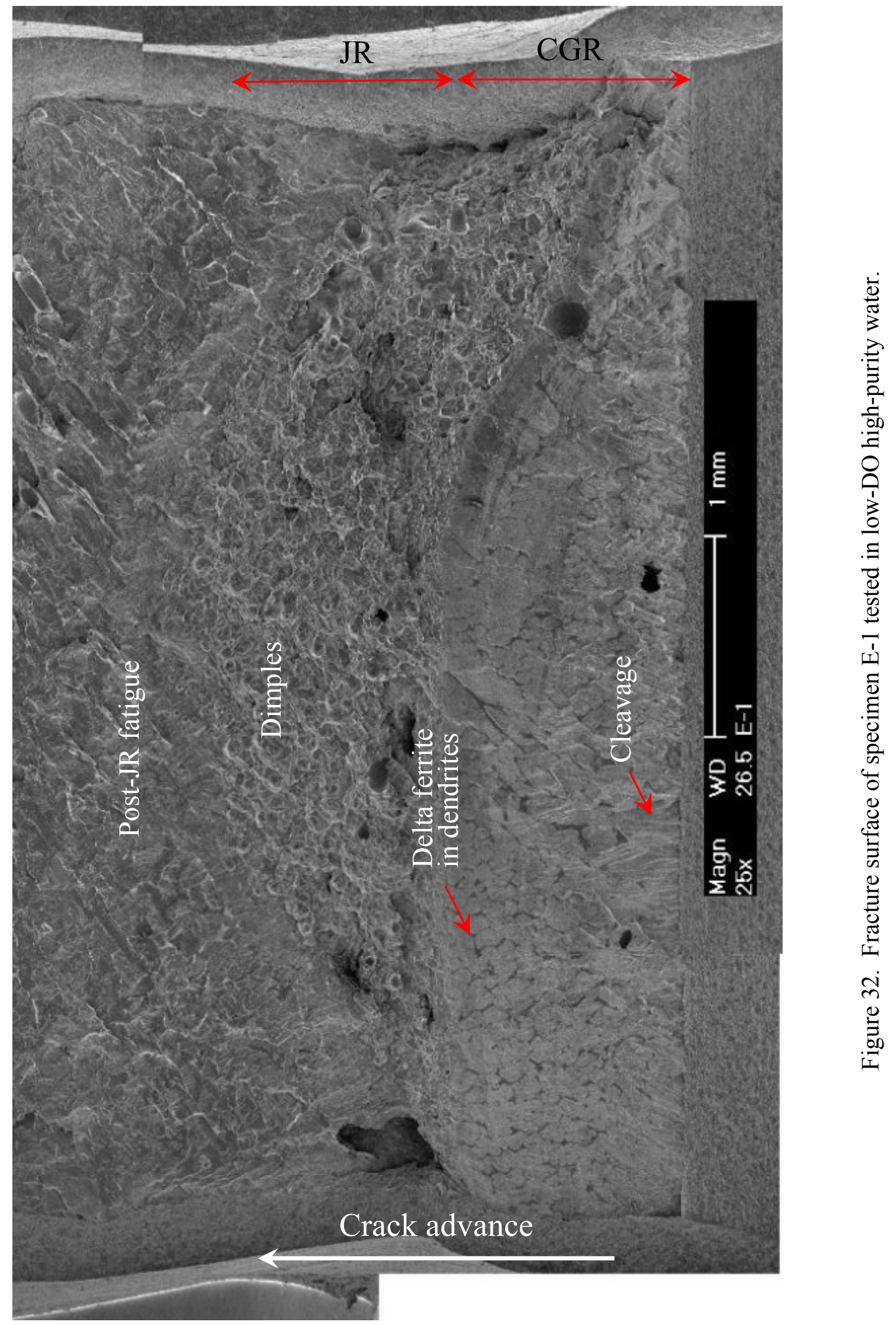




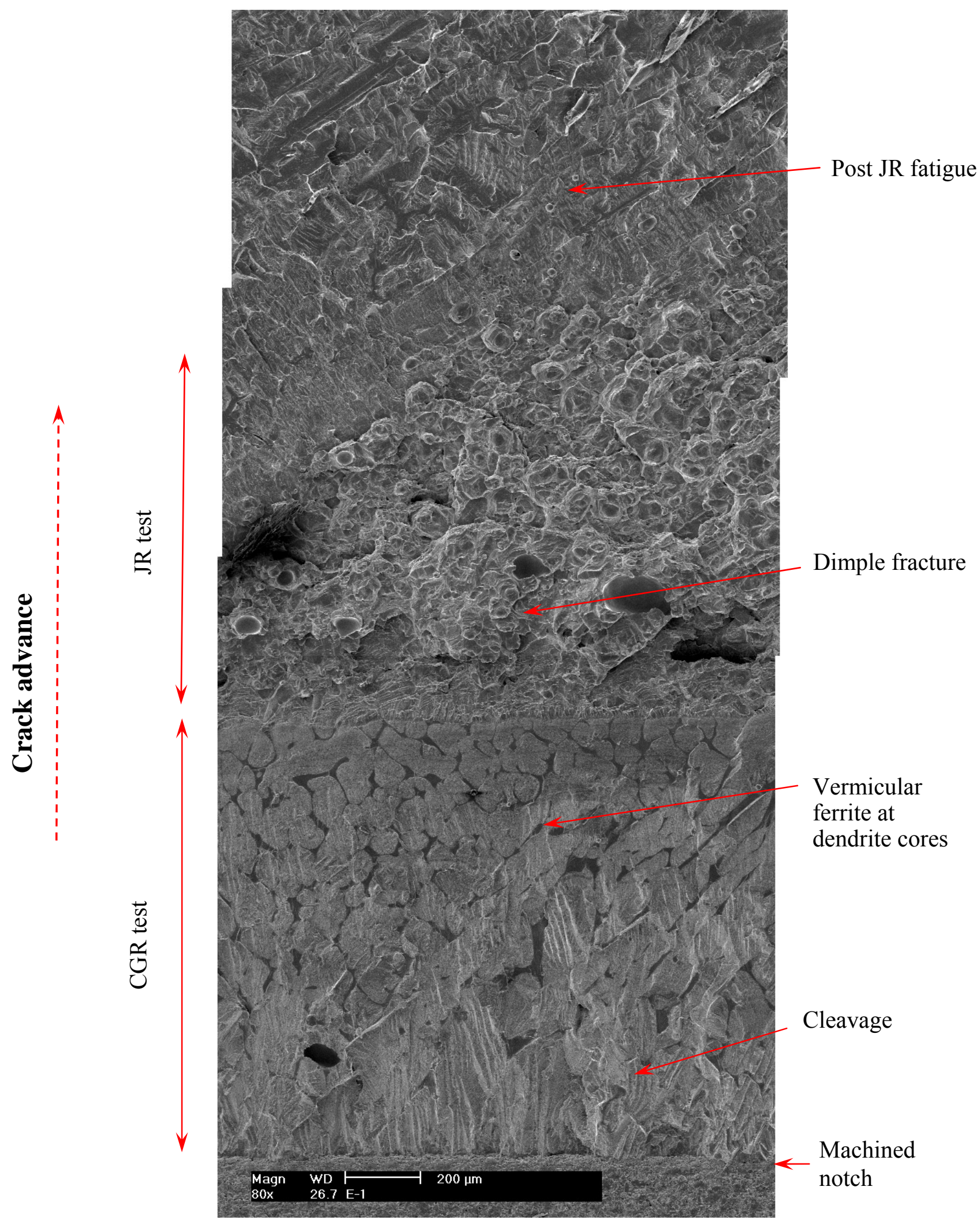

Figure 33. Fracture surface of specimen E-1 along the sample central line. 


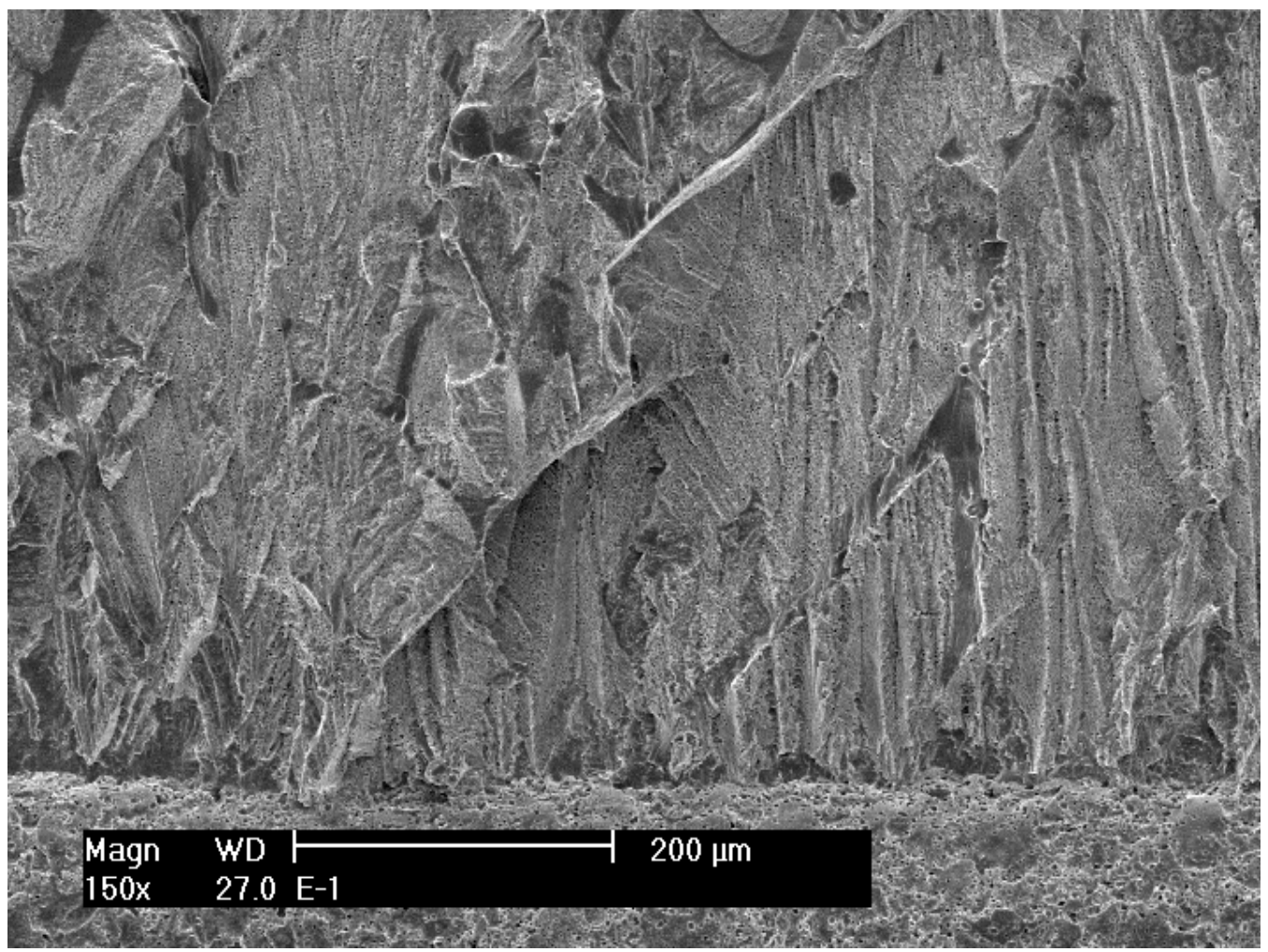

Figure 34. Cleavage cracking at the beginning of the CGR test of specimen E-1. Crack propagation from bottom to top.

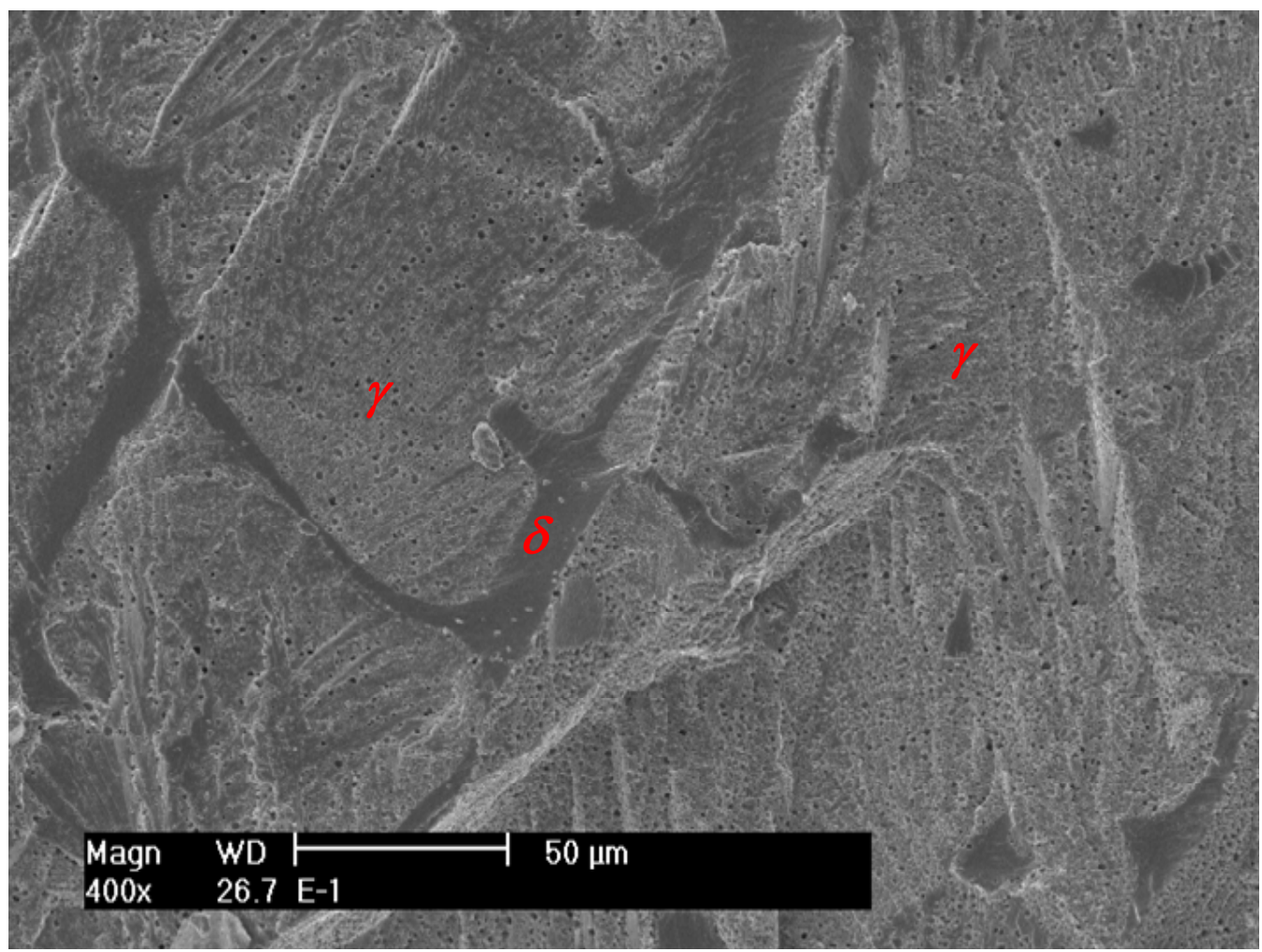

Figure 35. Cyclic CGR test region of specimen E-1. Crack propagation from bottom to top. 


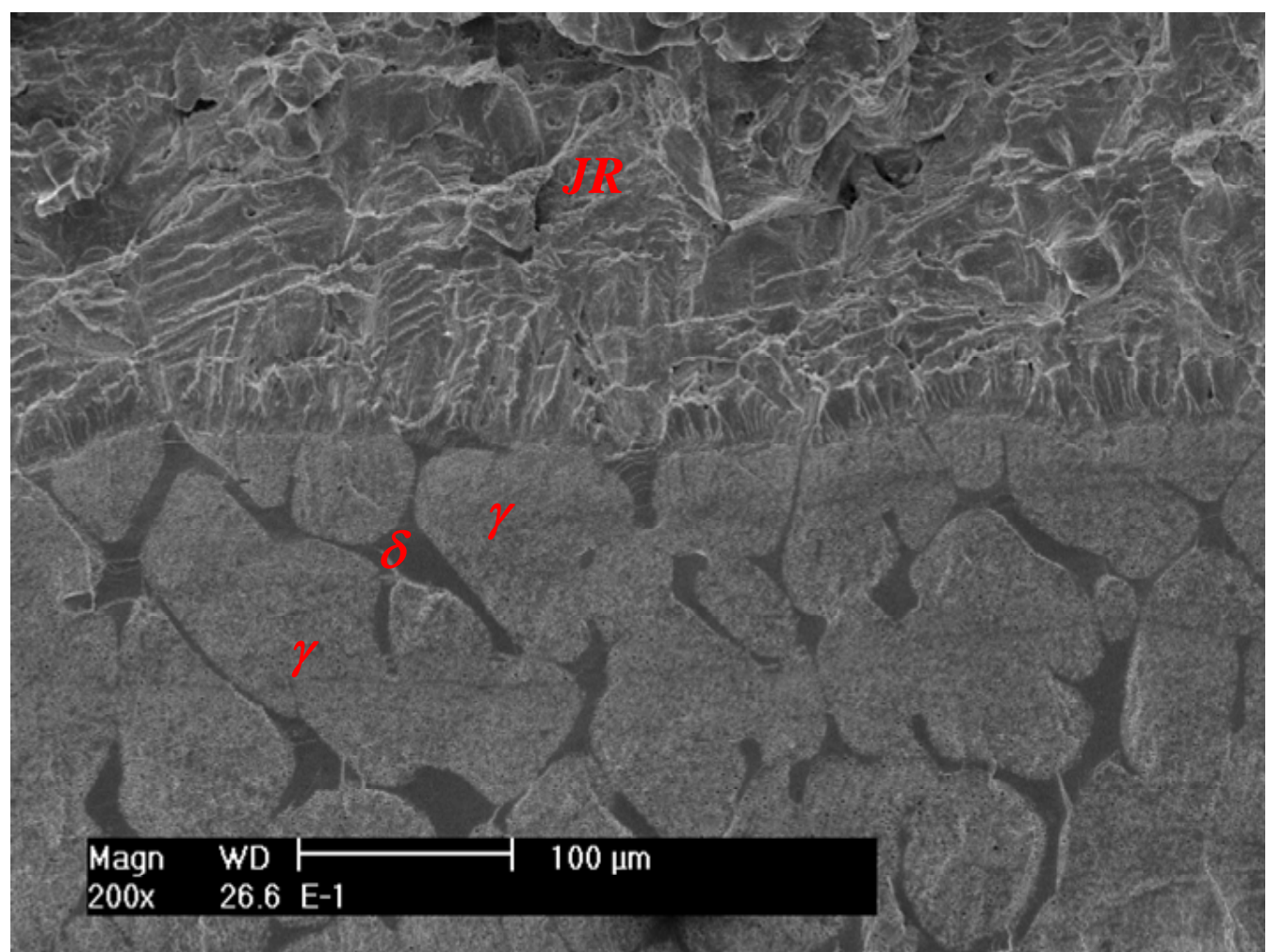

Figure 36. Smooth fracture surface at the end of the CGR test in specimen E-1. Crack propagation from bottom to top.

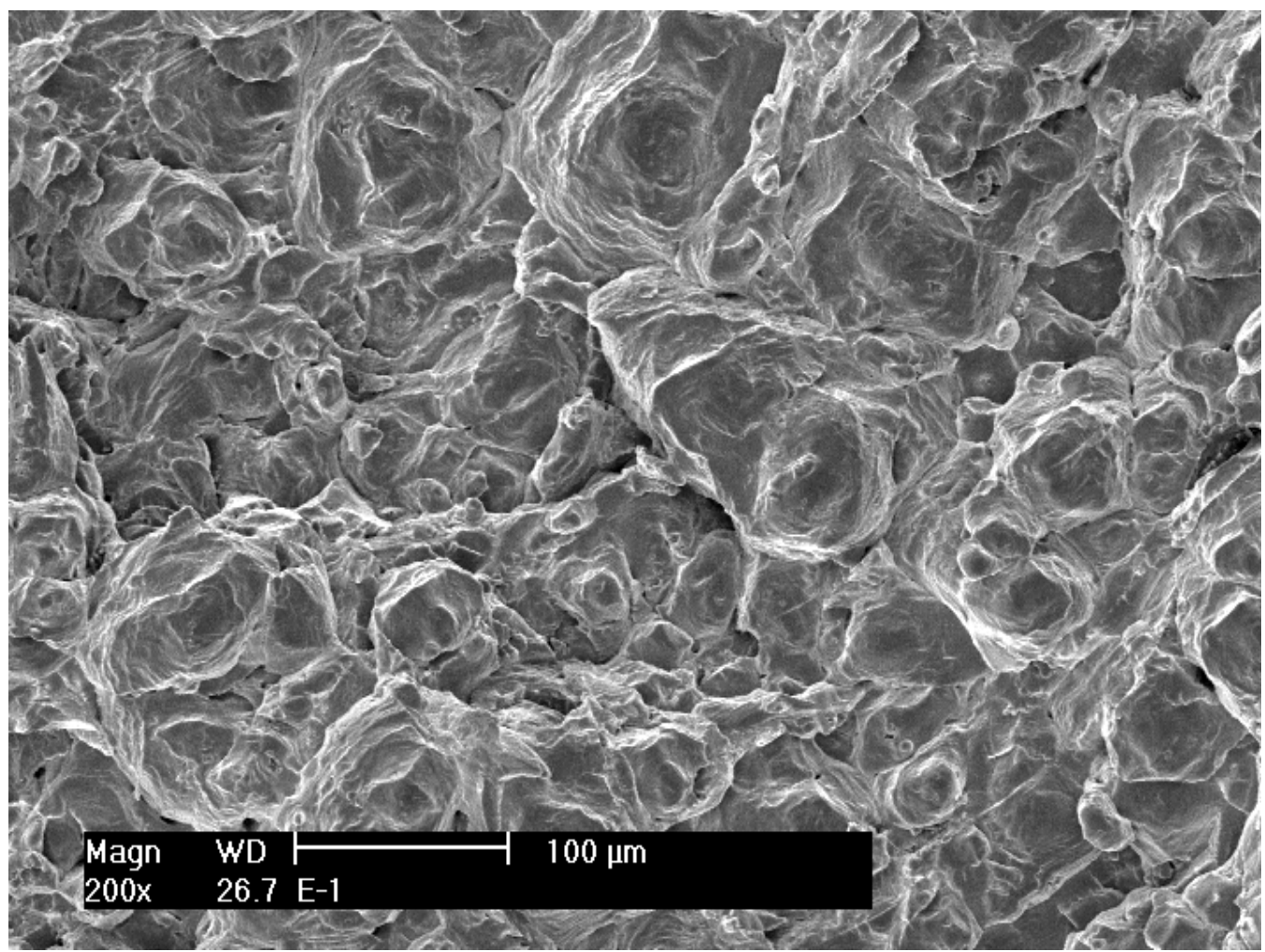

Figure 37. Ductile dimple fracture in the J-R test region of specimen E-1. Crack propagation from bottom to top. 


\subsubsection{Thermally Aged CF-8 SS}

\section{Crack growth rate test}

Specimen F-1 was a CF-8 CASS with 23\% ferrite cut from the same heat as specimen E-1 (Heat 68). The specimen was thermally aged at $400^{\circ} \mathrm{C}$ for $10,000 \mathrm{hr}$ prior to irradiation. This specimen was also tested in low-DO high-purity water at $320^{\circ} \mathrm{C}$. The CGR test conditions and results are summarized in Table 8, and a crack-length history plot is shown in Fig. 38.

The test was started with fatigue pre-cracking at a maximum stress intensity factor of $\sim 17 \mathrm{MPa} \mathrm{m}{ }^{1 / 2}$, load ratio of 0.2 , and frequency of $1 \mathrm{~Hz}$. Using a triangular waveform, the crack was advanced for about $500 \mu \mathrm{m}$ with gradually increased load ratio. After a saw-tooth waveform was introduced in test period $g$, environmentally enhanced cracking started to appear. In the following test periods, the maximum stress intensity factor was maintained at $\sim 16 \mathrm{MPa}$ $\mathrm{m}^{1 / 2}$ while the load ratio and rise time were gradually increased. A significant degree of environmental enhancement was readily established in this sample, similar to that observed in unaged CF-8 (specimen E-1). By the end of the cyclic CGR test, the measured CGR in water was about a factor of seven higher than that of the fatigue growth rate. All cyclic CGRs obtained from this sample are plotted in Fig. 39. The corrosion fatigue curve for unirradiated SSs still bounds the data points of the aged CF-8 CASS.

After the cyclic CGR test, the test was set at constant load with PPU every $2 \mathrm{hr}$. A SCC CGR of $2.69 \times 10^{-11} \mathrm{~m} / \mathrm{s}$ was measured at a stress intensity factor of $16 \mathrm{MPa} \mathrm{m}^{1 / 2}$ (Fig. 40). This growth rate is about a factor of three lower than the NUREG-0313 curve, and is very similar to that obtained from the unaged CF-8 CASS (specimen E-1).

Table 8. Crack growth rates of specimen F-1 (0.08-dpa aged CF-8 with $23 \% \delta$ ferrite) in a lowDO high-purity water environment.

\begin{tabular}{|l|l|l|l|l|l|l|l|l|l|l|l|}
\hline $\begin{array}{l}\text { Test } \\
\text { Period }\end{array}$ & $\begin{array}{l}\text { Test } \\
\text { time, } \\
\mathrm{h}\end{array}$ & $\begin{array}{l}\text { Test } \\
\text { Temp., } \\
{ }^{\circ} \mathrm{C}\end{array}$ & $\begin{array}{l}\text { Load } \\
\text { Ratio }\end{array}$ & $\begin{array}{l}\text { Rise } \\
\text { Time, } \\
\mathrm{s}\end{array}$ & $\begin{array}{l}\text { Return } \\
\text { Time, } \\
\mathrm{s}\end{array}$ & $\begin{array}{l}\text { Hold } \\
\text { Time, } \\
\mathrm{s}\end{array}$ & $\begin{array}{l}\text { Kmax, } \\
\mathrm{MPa} \mathrm{m}^{1 / 2}\end{array}$ & $\begin{array}{l}\Delta \mathrm{K}, \\
\mathrm{MPa} \mathrm{m}^{1 / 2}\end{array}$ & $\begin{array}{l}\text { CGR in } \\
\text { Env., } \\
\mathrm{m} / \mathrm{s}\end{array}$ & $\begin{array}{l}\text { CGR } \\
\text { in Air } \\
\mathrm{m} / \mathrm{s}\end{array}$ & $\begin{array}{l}\text { Crack } \\
\text { Length, } \\
\mathrm{mm}\end{array}$ \\
\hline Start & 0.4 & & & & & & & & & & \\
\hline $\mathrm{a}$ & 2.0 & 319 & 0.20 & 0.45 & 0.45 & 0.05 & 17.3 & 13.8 & $6.84 \mathrm{E}-08$ & $6.51 \mathrm{E}-08$ & 6.196 \\
\hline $\mathrm{b}$ & 3.9 & 319 & 0.30 & 0.44 & 0.44 & 0.06 & 16.4 & 11.4 & $4.28 \mathrm{E}-08$ & $4.04 \mathrm{E}-08$ & 6.323 \\
\hline $\mathrm{c}$ & 5.7 & 319 & 0.40 & 0.42 & 0.42 & 0.08 & 15.4 & 9.2 & $1.11 \mathrm{E}-08$ & $2.29 \mathrm{E}-08$ & 6.358 \\
\hline $\mathrm{d}$ & 8.2 & 319 & 0.40 & 0.84 & 0.84 & 0.16 & 15.4 & 9.3 & $6.40 \mathrm{E}-09$ & $1.16 \mathrm{E}-08$ & 6.382 \\
\hline $\mathrm{e}$ & 11.7 & 319 & 0.35 & 0.85 & 0.85 & 0.15 & 15.6 & 10.1 & $1.13 \mathrm{E}-08$ & $1.46 \mathrm{E}-08$ & 6.440 \\
\hline $\mathrm{f}$ & 24.2 & 319 & 0.35 & 4.25 & 4.25 & 0.75 & 15.6 & 10.1 & $3.20 \mathrm{E}-09$ & $2.94 \mathrm{E}-09$ & 6.505 \\
\hline $\mathrm{g}$ & 36.7 & 319 & 0.35 & 10.2 & 4.25 & 1.81 & 15.7 & 10.2 & $2.06 \mathrm{E}-09$ & $1.25 \mathrm{E}-09$ & 6.561 \\
\hline $\mathrm{h}$ & 49.4 & 319 & 0.40 & 16.8 & 4.19 & 3.25 & 15.6 & 9.4 & $1.36 \mathrm{E}-09$ & $6.18 \mathrm{E}-10$ & 6.601 \\
\hline $\mathrm{i}$ & 76.8 & 319 & 0.39 & 33.5 & 10.05 & 6.5 & 15.8 & 9.6 & $7.62 \mathrm{E}-10$ & $3.22 \mathrm{E}-10$ & 6.650 \\
\hline $\mathrm{j}$ & 120.9 & 319 & 0.39 & 83.6 & 10.04 & 16.4 & 15.7 & 9.6 & $3.05 \mathrm{E}-10$ & $1.30 \mathrm{E}-10$ & 6.685 \\
\hline $\mathrm{k}$ & 168 & 319 & 0.44 & 247.6 & 9.91 & 52.4 & 15.8 & 8.9 & $1.69 \mathrm{E}-10$ & $3.64 \mathrm{E}-11$ & 6.708 \\
\hline 1 & 224 & 319 & 0.44 & 495.0 & 9.90 & 105.0 & 16.0 & 8.9 & $8.94 \mathrm{E}-11$ & $1.84 \mathrm{E}-11$ & 6.723 \\
\hline $\mathrm{m}$ & 290.3 & 320 & 0.44 & 824.9 & 9.90 & 175.1 & 16.0 & 9.0 & $7.17 \mathrm{E}-11$ & $1.11 \mathrm{E}-11$ & 6.735 \\
\hline 1 & 359.3 & 318 & 0.45 & 12 & 12 & 7200 & 16.0 & 8.8 & $2.69 \mathrm{E}-11$ & $1.20 \mathrm{E}-12$ & 6.749 \\
\hline
\end{tabular}


(a)

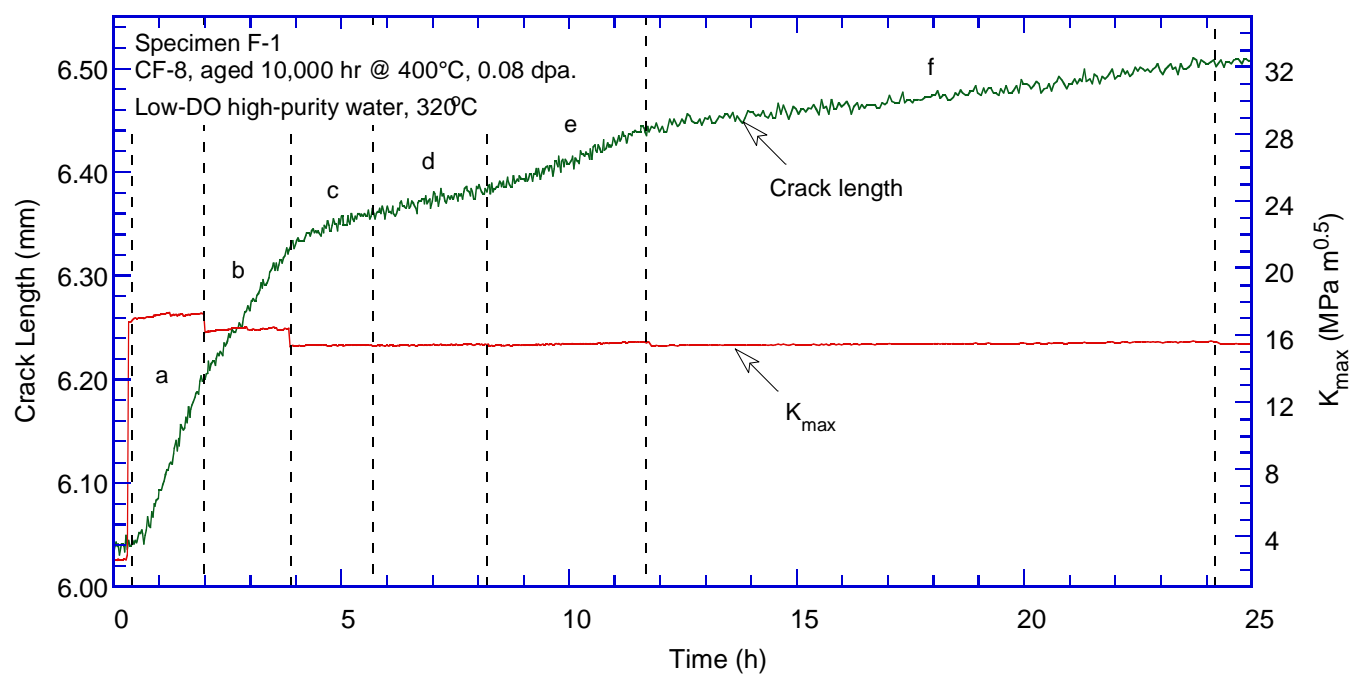

(b)

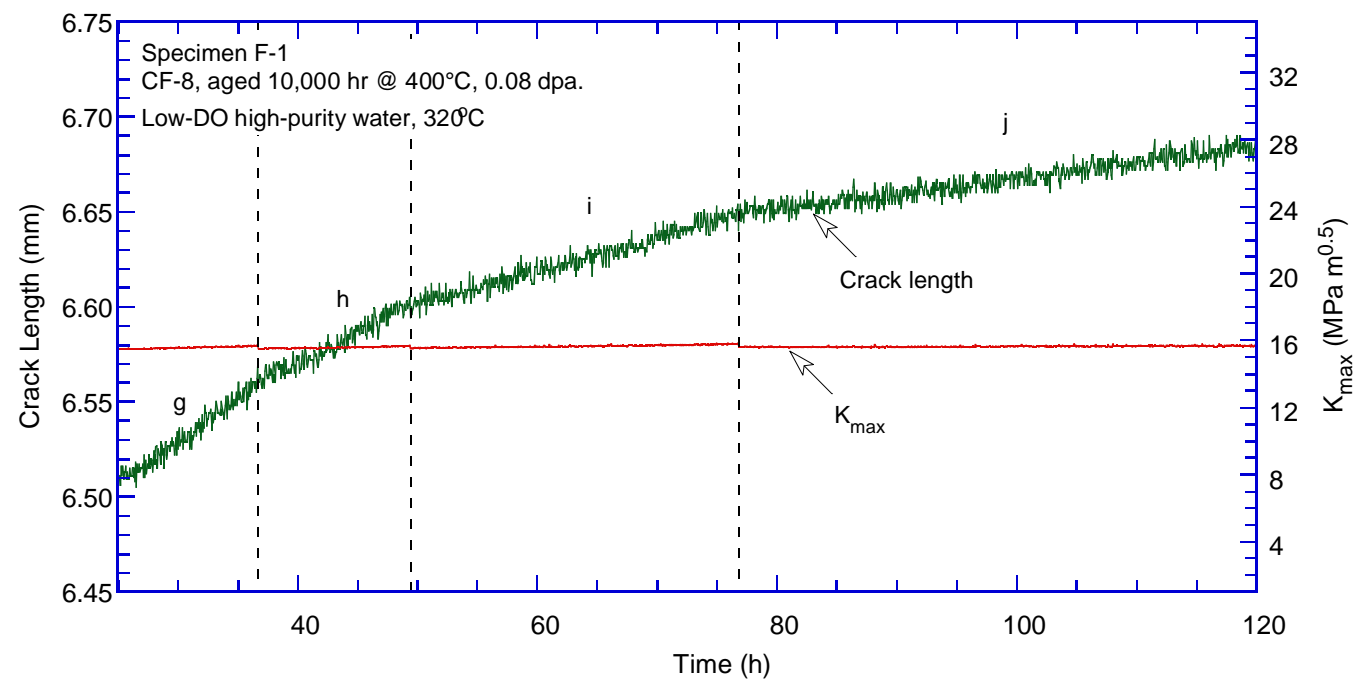

(c)

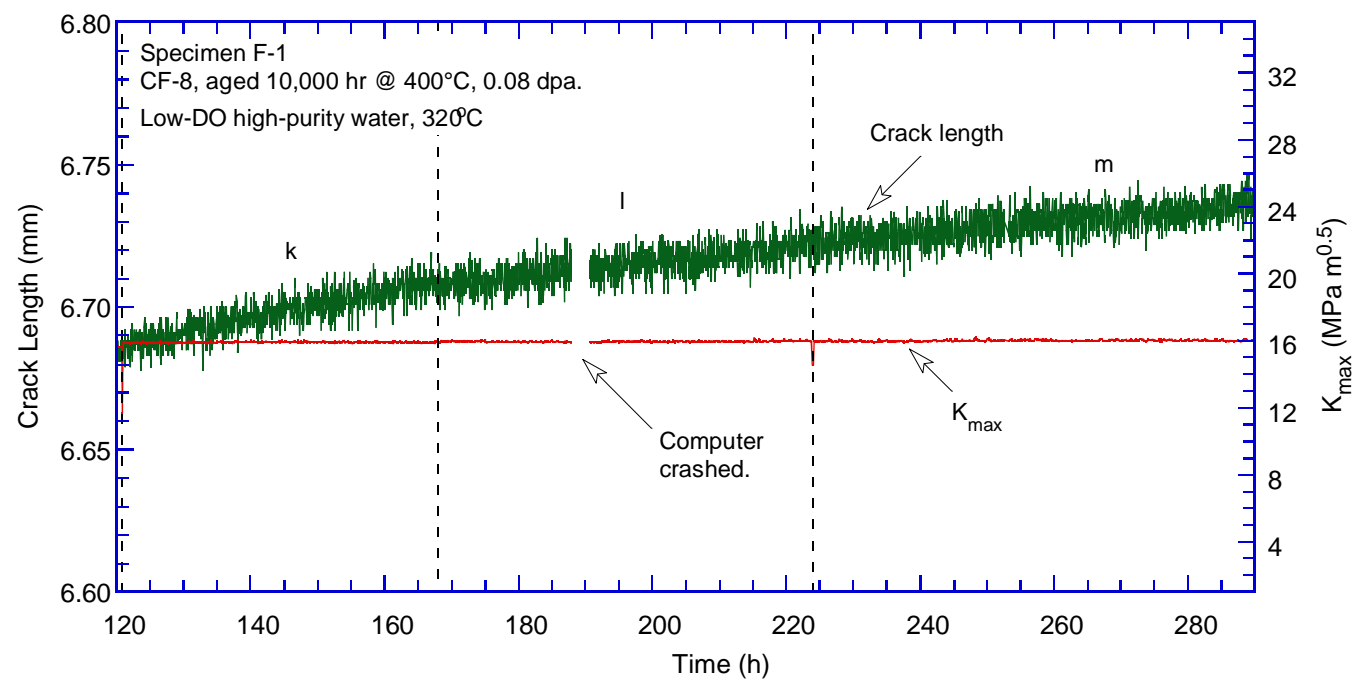

Figure 38. Crack-length-vs.-time plot for specimen F-1 (0.08-dpa aged CF-8 with 23\% ferrite): test periods (a) a-f, (b) g-j, (c) k-m, and (d) 1. 
(d)

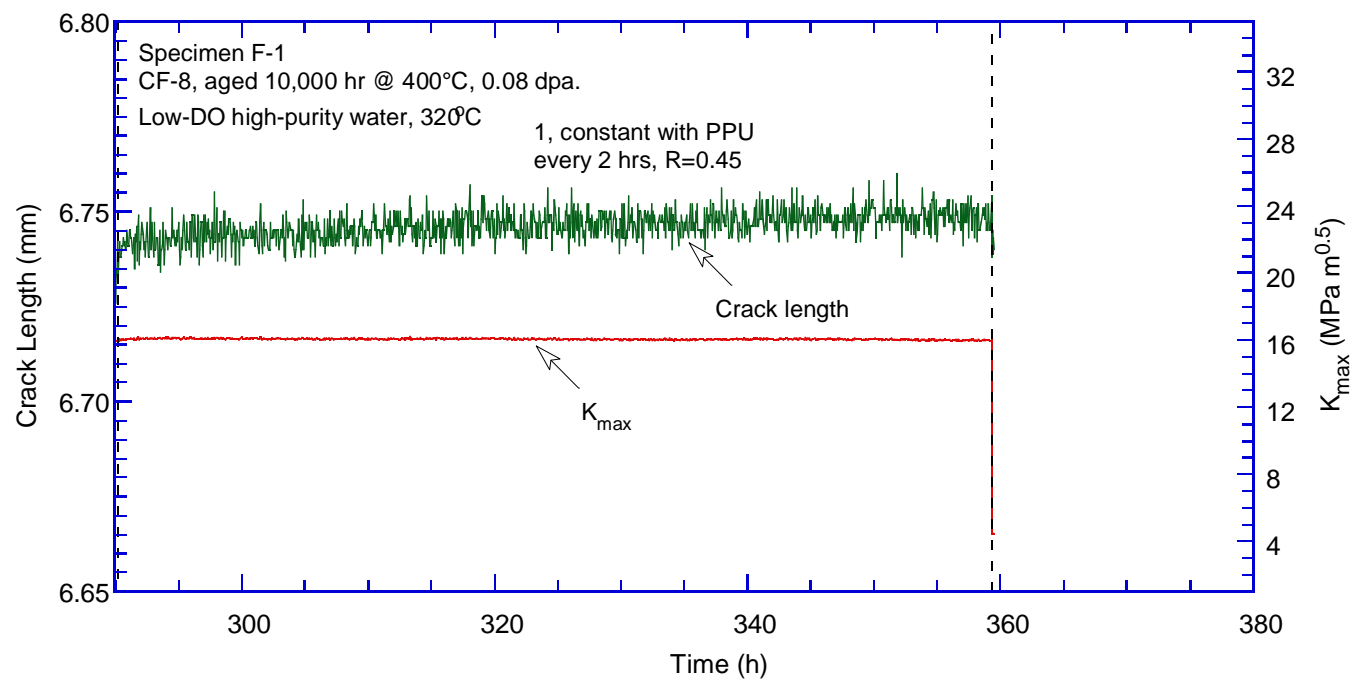

Figure 38. (Contd.)

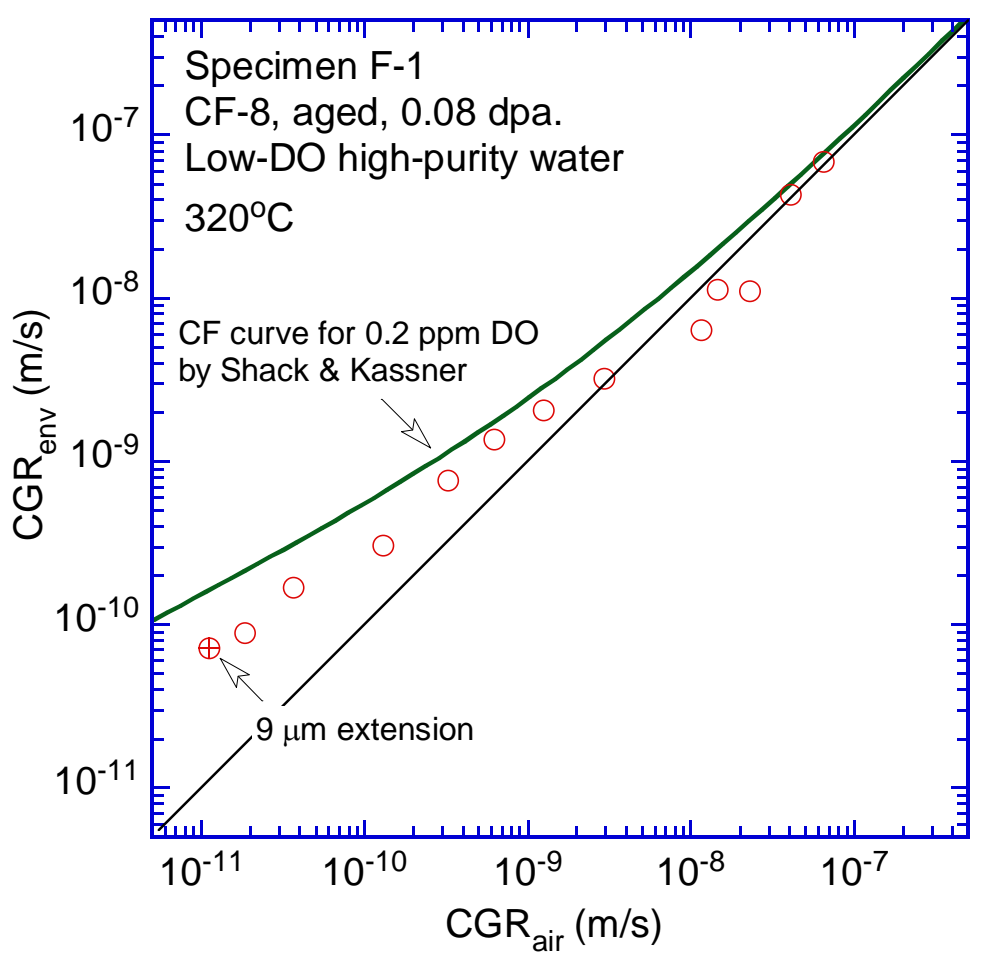

Figure 39. Cyclic CGRs of Specimen F-1.

Fracture toughness JR curve test

Following the CGR test, a fracture toughness JR curve test was performed on the same sample in the test environment. Figure 41 shows the obtained data, and a power-law fitting gives rise to a $J R$ curve of $J=372 \Delta \mathrm{a}^{0.62}$. The estimated $J$ value at the $0.2-\mathrm{mm}$ offset line is $171 \mathrm{~kJ} / \mathrm{m}^{2}$. Note that the J-R curve data cannot be validated because one of the nine measurements of the final 
crack size did not meet the requirements. Some $\mathbf{J}$ values used in the analysis were also above the limit for this sample.

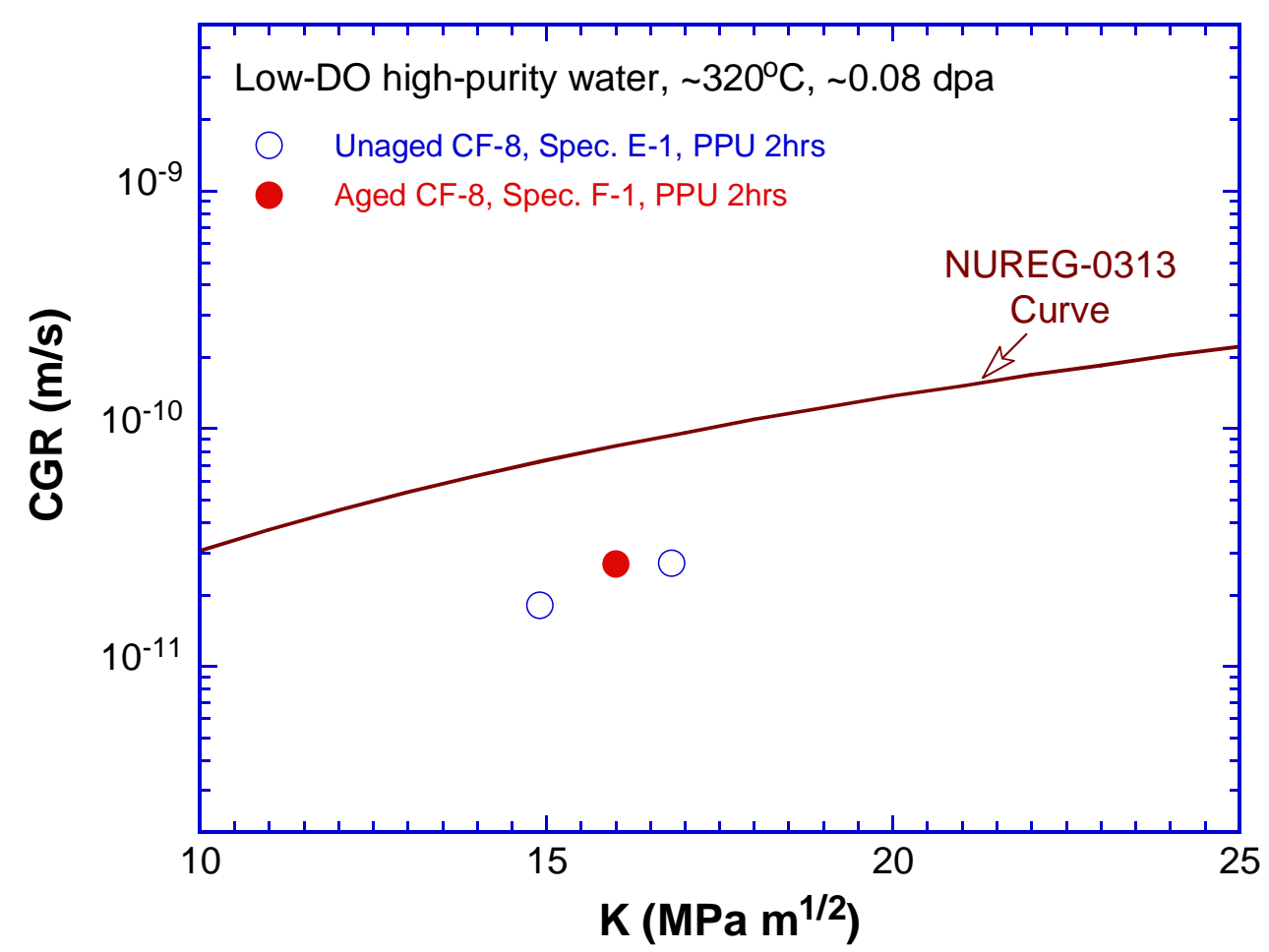

Figure 40. SCC CGRs of unaged and aged CF-8 CASS with 23\% ferrite irradiated to 0.08 dpa.

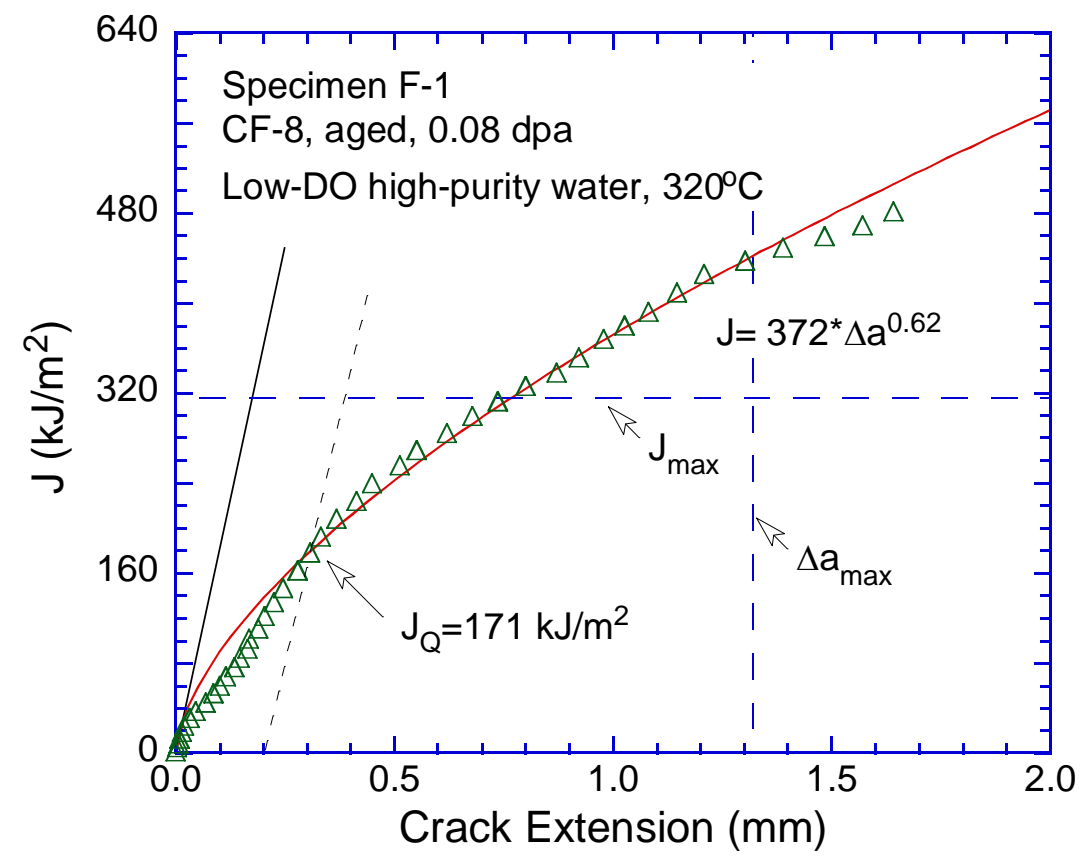

Figure 41. The J-R curve of specimen F-1. 


\section{Fractographic examination}

Replicas of the fracture surface of specimen F-1 were examined with SEM. As shown in Figs. 42 and 43, transgranular cleavage cracking is the main fracture mode during the pre-cracking stage. Cleavage steps are clearly visible next to the machine notch. As the crack advances, the fracture surface became increasingly smoother, suggesting the crack had propagated in a progressively more brittle fashion (Fig. 44). Also, as shown in Fig. 45, cleavage steps seem to develop in the austenitic phase surrounding the ferritic phase at dendrite cores. Deformation ledges are less often seen within the ferrite. Finally, after the CGR test, the fracture surface became completely ductile. The sample was fractured by ductile tearing in the JR curve test (Fig. 46). 


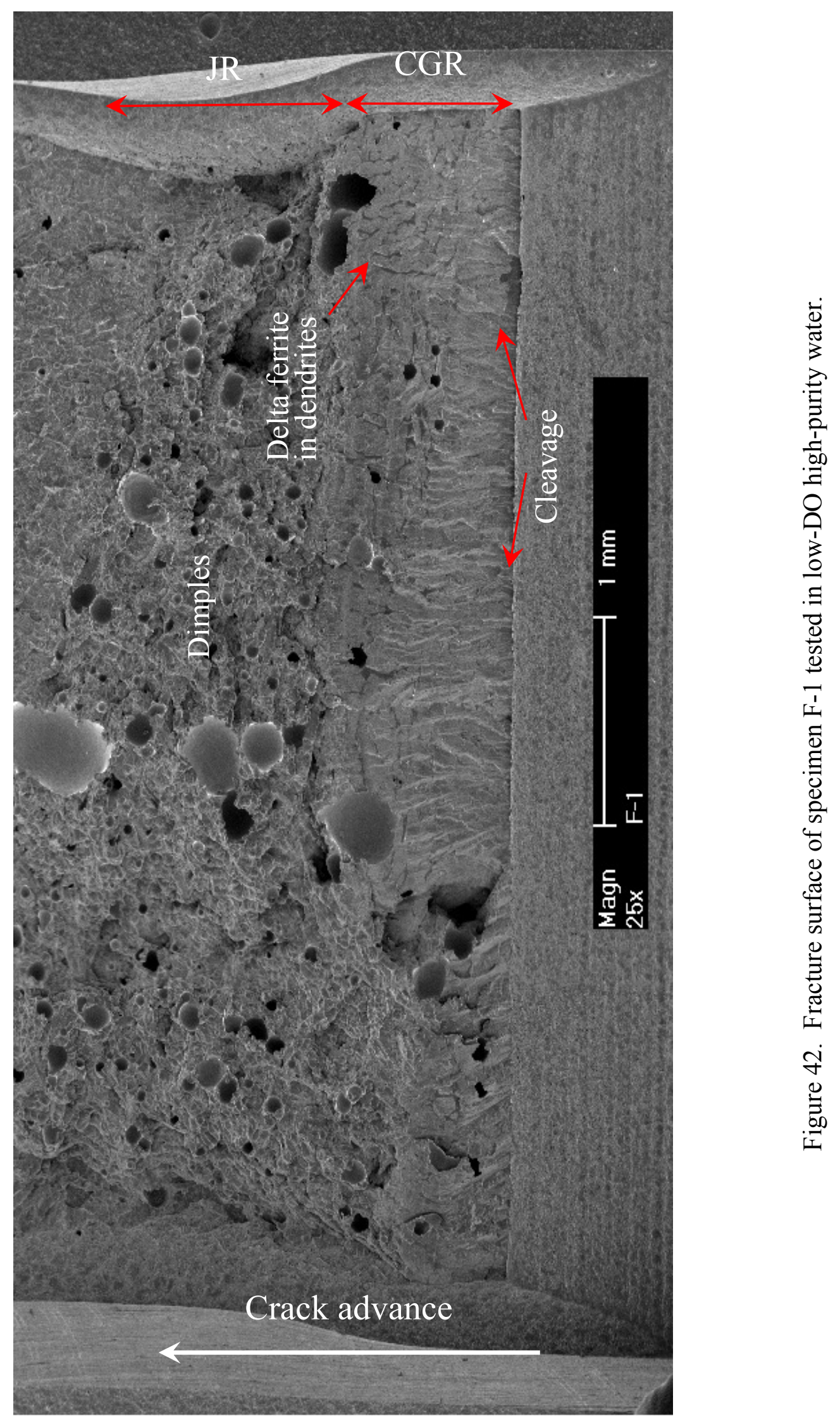




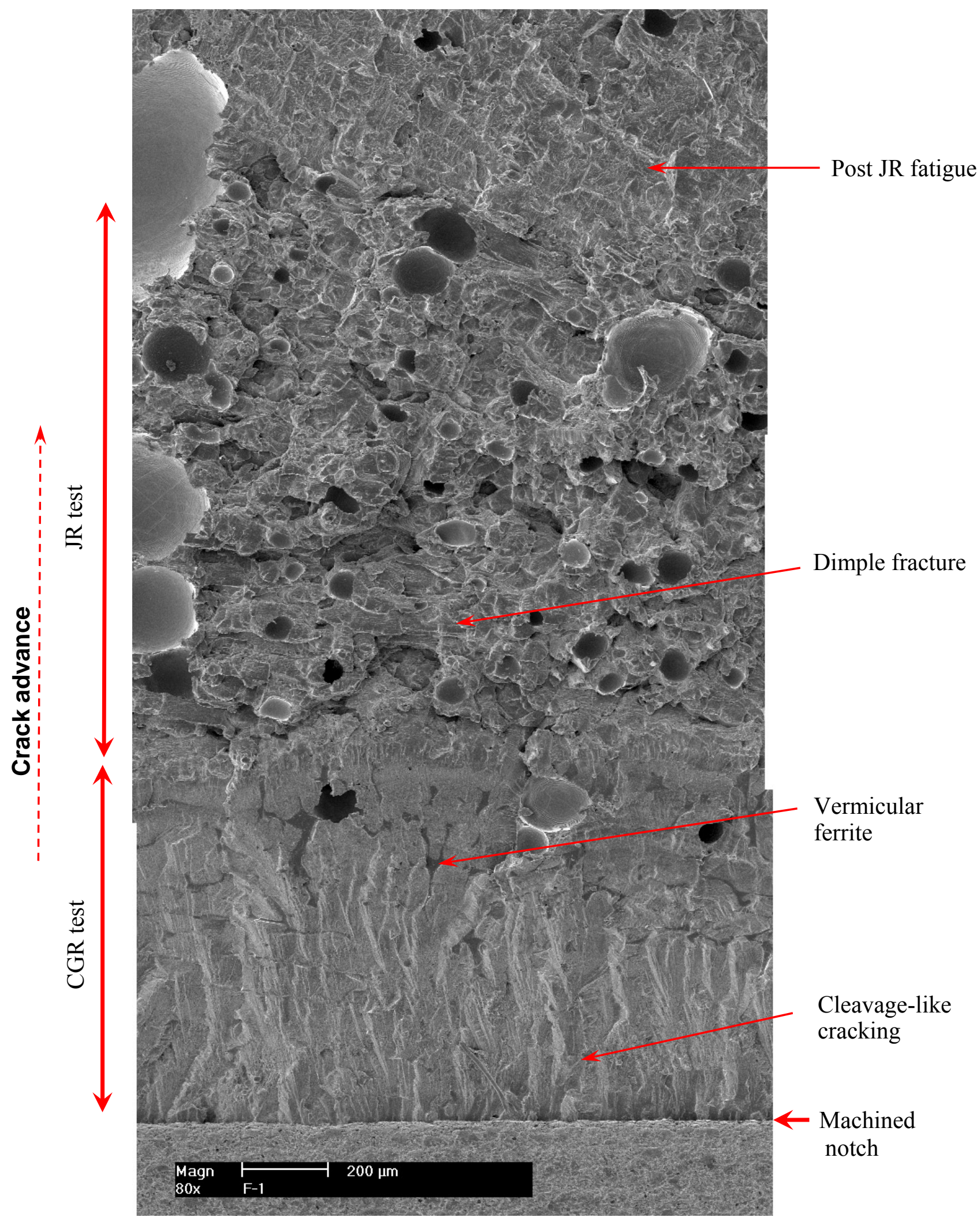

Figure 43. Fracture surface of specimen F-1 along the sample central line. 


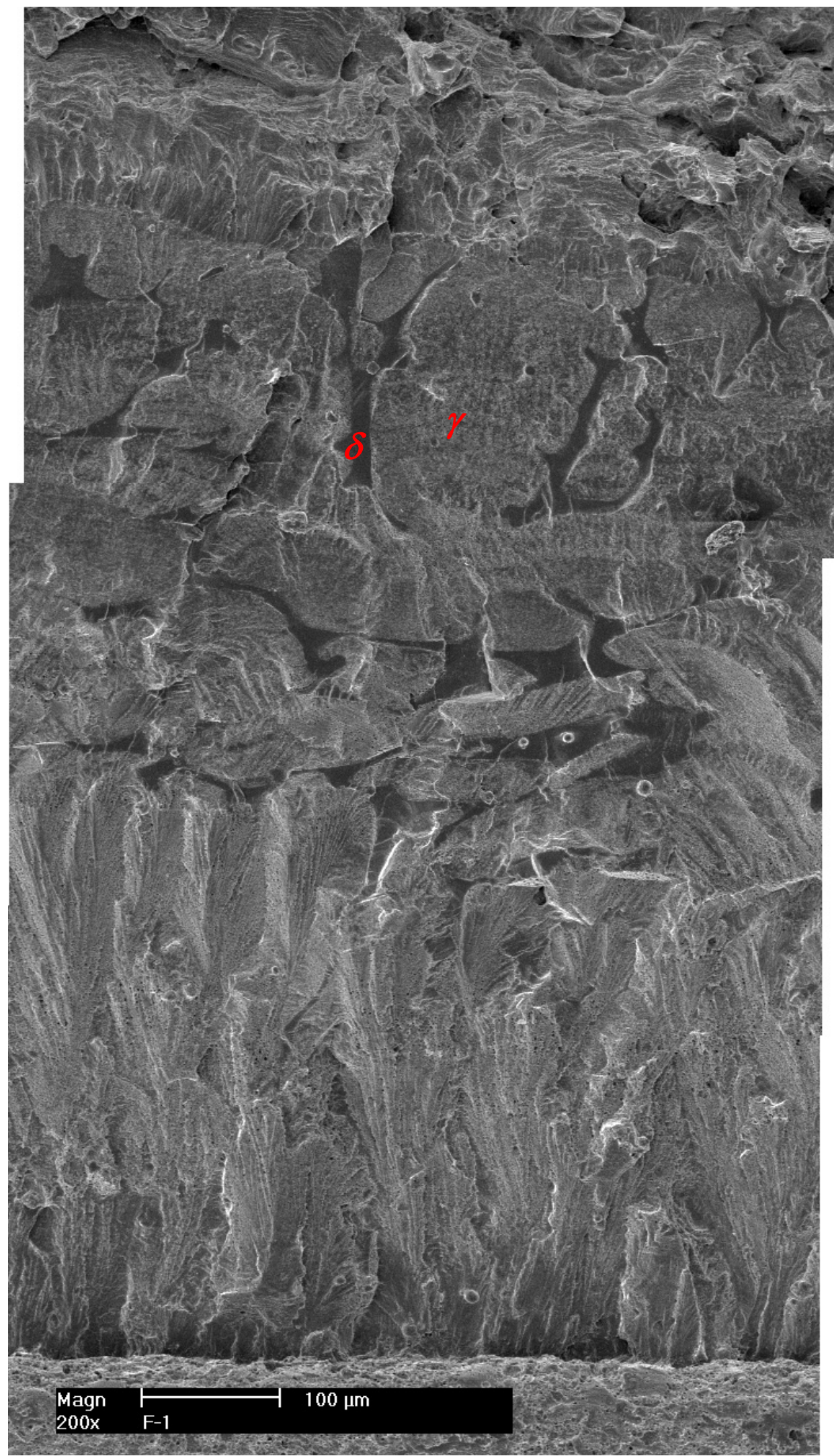

Figure 44. Fracture surface of the CGR region in specimen F-1. Crack propagation from bottom to top. 


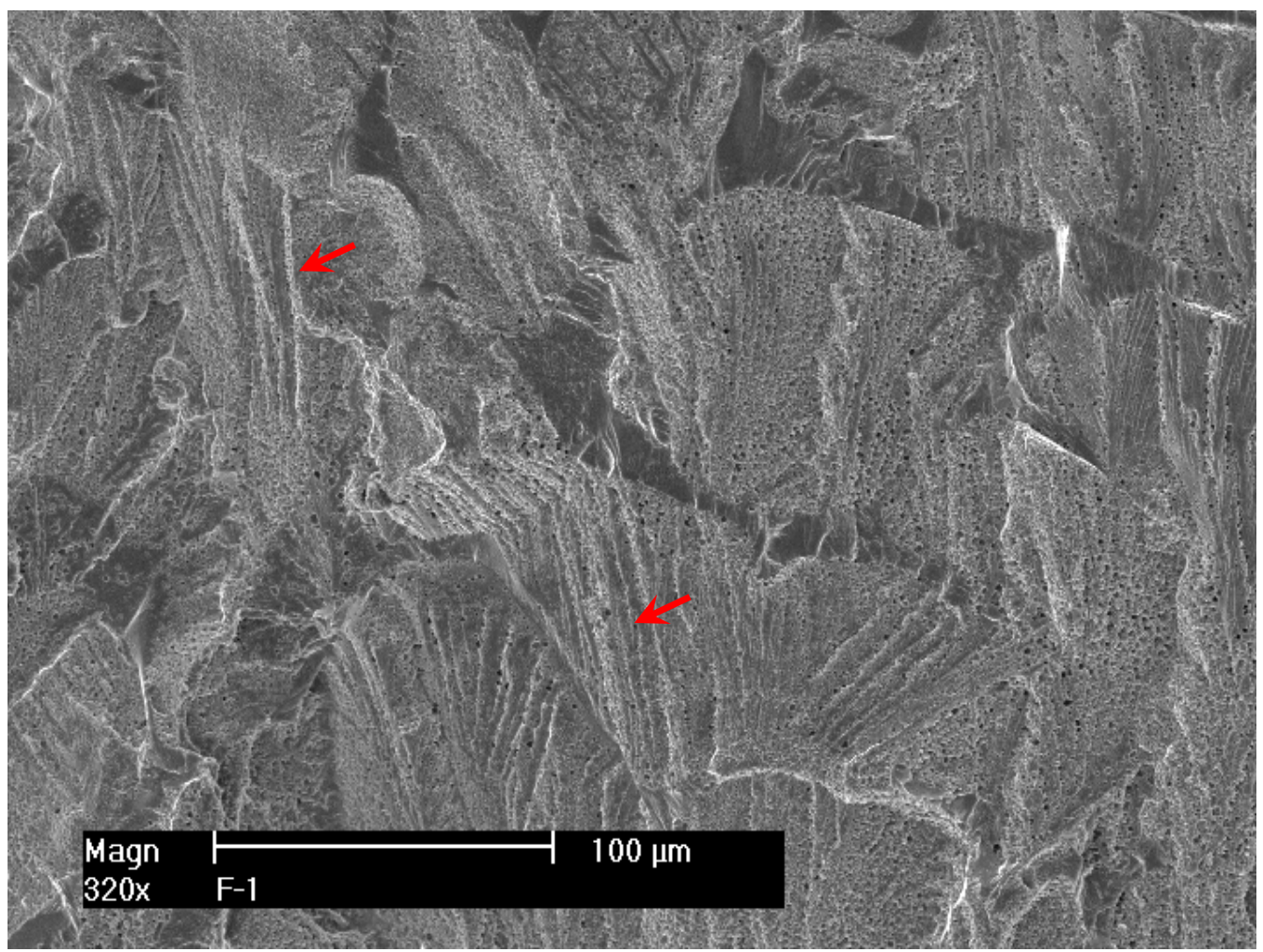

Figure 45. Cleavage steps in austenite grain around ferrite phase in the CGR test region of specimen F-1. Crack propagation from bottom to top.

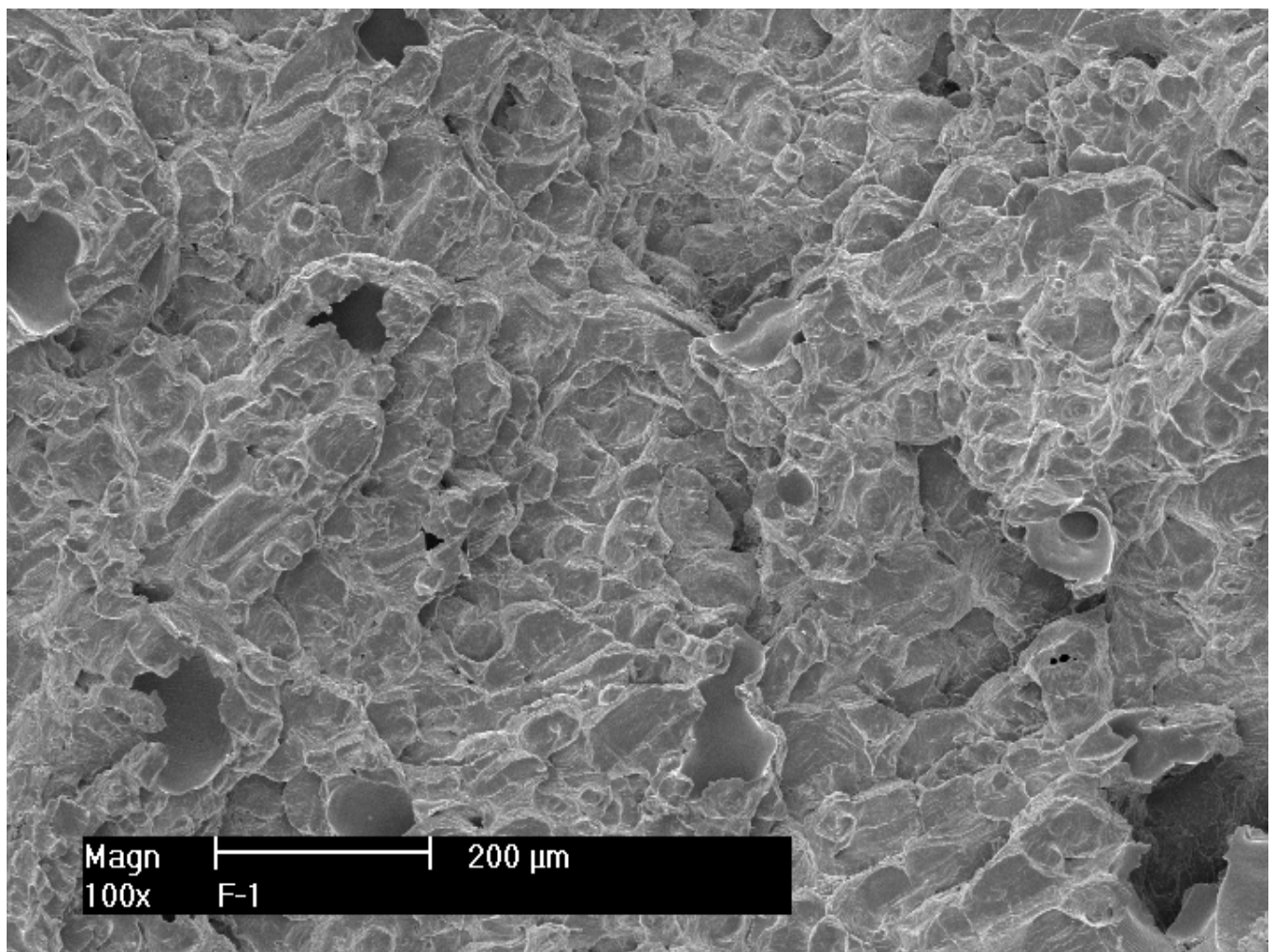

Figure 46. Dimple fracture in the JR test region of specimen F-1. Crack propagation from bottom to top. 


\subsection{CF-8M Stainless Steel}

\subsubsection{Unaged CF-8M}

\section{$\underline{\text { Crack growth rate test }}$}

Specimen I-1 was an unaged CF-8M CASS with $28 \%$ ferrite (Heat 75 ) irradiated to 0.08 dpa. The specimen was tested in a low-DO high-purity water environment at $320^{\circ} \mathrm{C}$. The objective was to compare the results with those of its thermally aged equivalent. The CGR test conditions and results are summarized in Table 9, and a crack-length history plot is shown in Fig. 47.

Fatigue pre-cracking was started with a triangular waveform at a maximum stress intensity factor of $\sim 14 \mathrm{MPa} \mathrm{m}{ }^{1 / 2}$, a load ratio of 0.2 , and frequency of $2 \mathrm{~Hz}$. After the crack was initiated from the notch, several test periods with an increasing rise time and load ratio were carried out to stimulate environmentally assisted cracking. Two repeated attempts were made until environmental enhancement started to appear in test period $n$. In the following test periods, the enhancement was stabilized successfully at a maximum stress intensity factor of $\sim 15.5 \mathrm{MPa}$ $\mathrm{m}^{1 / 2}$. Before the test was set at constant load, a hydraulic pump tripped. Consequently, the actuator of the test system was switched off automatically. To eliminate any possible overloading effect, additional test periods (from $s$ to $a c$ ) were added after the system was recovered to repeat the transition. Under a similar loading condition, a similar degree of environmental enhancement was re-established in test period $x$ and became stabilized in the following test periods. By the end of test period $a c$, the measured CGR was more than a factor of 10 higher than the fatigue crack growth rate curve in air.

All cyclic CGRs obtained from this sample are plotted in Fig. 48. The data points are close to and sometime higher than the corrosion fatigue curve for unirradiated SSs. It appears that this CF-8M CASS is more susceptible to cracking compared to CF-3 and CF-8. The test was then set at constant load with PPU every $2 \mathrm{hr}$. A CGR of $1.27 \times 10^{-11} \mathrm{~m} / \mathrm{s}$ was recorded at $\sim 18 \mathrm{MPa} \mathrm{m}{ }^{1 / 2}$ over $26-\mu \mathrm{m}$ cracking extension. This SCC CGR is still significantly lower than the NUREG0313 curve. 
Table 9. Crack growth rates of specimen I-1 (0.08-dpa unaged CF-8M with $28 \% \delta$ ferrite) in a low-DO high-purity water environment.

\begin{tabular}{|c|c|c|c|c|c|c|c|c|c|c|c|}
\hline $\begin{array}{l}\text { Test } \\
\text { Period }\end{array}$ & $\begin{array}{l}\text { Test } \\
\text { Time, } \\
\mathrm{h} \\
\end{array}$ & $\begin{array}{l}\text { Test } \\
\text { Temp., } \\
{ }^{\circ} \mathrm{C}\end{array}$ & $\begin{array}{l}\text { Load } \\
\text { Ratio }\end{array}$ & $\begin{array}{l}\text { Rise } \\
\text { Time, } \\
\mathrm{S} \\
\end{array}$ & $\begin{array}{l}\text { Return } \\
\text { Time, } \\
\mathrm{s} \\
\end{array}$ & $\begin{array}{l}\text { Hold } \\
\text { Time, } \\
\text { s } \\
\end{array}$ & $\begin{array}{l}\text { Kmax, } \\
\mathrm{MPa} \mathrm{m}^{1 / 2}\end{array}$ & $\begin{array}{l}\Delta \mathrm{K} \\
\mathrm{MPa} \mathrm{m}^{1 / 2}\end{array}$ & $\begin{array}{l}\text { CGR in } \\
\text { Env., } \\
\mathrm{m} / \mathrm{s}\end{array}$ & $\begin{array}{l}\text { CGR } \\
\text { in Air, } \\
\mathrm{m} / \mathrm{s} \\
\end{array}$ & $\begin{array}{l}\text { Crack } \\
\text { Length, } \\
\mathrm{mm}\end{array}$ \\
\hline Start & 0.9 & & & & & & & & & & 5.977 \\
\hline $\mathrm{a}^{\mathrm{a}}$ & 3.11 & 319 & 0.23 & 0.21 & 0.21 & 0.04 & 14.3 & 11.0 & $5.09 \mathrm{E}-08$ & $6.72 \mathrm{E}-08$ & 6.127 \\
\hline $\mathrm{b}$ & 5.0 & 319 & 0.36 & 0.20 & 0.20 & 0.05 & 12.7 & 8.1 & $2.74 \mathrm{E}-09$ & $3.02 \mathrm{E}-08$ & 6.134 \\
\hline $\mathrm{c}$ & 6.5 & 319 & 0.33 & 0.21 & 0.21 & 0.04 & 14.2 & 9.6 & $4.10 \mathrm{E}-08$ & 4.87E-08 & 6.225 \\
\hline $\mathrm{d}$ & 9.8 & 319 & 0.43 & 0.40 & 0.40 & 0.10 & 14.2 & 8.1 & $1.27 \mathrm{E}-08$ & $1.61 \mathrm{E}-08$ & 6.285 \\
\hline $\mathrm{e}$ & 23.9 & 319 & 0.53 & 0.76 & 0.76 & 0.24 & 14.2 & 6.6 & $1.47 \mathrm{E}-09$ & 4.79E-09 & 6.315 \\
\hline $\mathrm{f}$ & 26.5 & 319 & 0.49 & 0.78 & 0.78 & 0.22 & 14.1 & 7.3 & $8.93 \mathrm{E}-10$ & $6.14 \mathrm{E}-09$ & 6.316 \\
\hline $\mathrm{g}$ & 28.6 & 319 & 0.30 & 0.83 & 0.83 & 0.17 & 14.7 & 10.2 & $2.38 \mathrm{E}-08$ & $1.47 \mathrm{E}-08$ & 6.371 \\
\hline $\mathrm{h}$ & 31.4 & 319 & 0.40 & 0.81 & 0.81 & 0.19 & 14.8 & 8.8 & $1.48 \mathrm{E}-08$ & $1.04 \mathrm{E}-08$ & 6.434 \\
\hline $\mathrm{i}$ & 37 & 320 & 0.45 & 1.98 & 1.98 & 0.52 & 14.8 & 8.1 & $3.91 \mathrm{E}-09$ & $3.33 \mathrm{E}-09$ & 6.463 \\
\hline $\mathrm{j}$ & 47.9 & 319 & 0.45 & 3.94 & 3.94 & 1.06 & 14.8 & 8.1 & $1.89 \mathrm{E}-09$ & $1.67 \mathrm{E}-09$ & 6.495 \\
\hline $\mathrm{k}$ & 56.7 & 320 & 0.45 & 7.88 & 3.94 & 2.12 & 14.8 & 8.1 & $1.19 \mathrm{E}-09$ & $8.46 \mathrm{E}-10$ & 6.513 \\
\hline 1 & 72.8 & 319 & 0.45 & 15.8 & 3.94 & 4.24 & 14.8 & 8.1 & $5.61 \mathrm{E}-10$ & $4.27 \mathrm{E}-10$ & 6.534 \\
\hline $\mathrm{m}$ & 104.5 & 319 & 0.45 & 23.6 & 3.94 & 6.37 & 14.8 & 8.2 & $2.28 \mathrm{E}-10$ & $2.87 \mathrm{E}-10$ & 6.551 \\
\hline$n^{a}$ & 153.1 & 319 & 0.45 & 47.2 & 3.94 & 12.8 & 14.9 & 8.2 & $3.09 \mathrm{E}-10$ & $1.46 \mathrm{E}-10$ & 6.578 \\
\hline 0 & 176.2 & 320 & 0.45 & 94.5 & 9.45 & 25.5 & 15.0 & 8.3 & $3.71 \mathrm{E}-10$ & $7.47 \mathrm{E}-11$ & 6.605 \\
\hline $\mathrm{p}^{\mathrm{a}}$ & 240 & 319 & 0.50 & 231.1 & 9.24 & 68.9 & 15.1 & 7.5 & $3.17 \mathrm{E}-10$ & $2.38 \mathrm{E}-11$ & 6.634 \\
\hline $\mathrm{q}$ & 335.4 & 320 & 0.50 & 461.4 & 9.23 & 138.6 & 15.0 & 7.6 & $1.49 \mathrm{E}-10$ & $1.21 \mathrm{E}-11$ & 6.676 \\
\hline $\mathrm{r}$ & 363.8 & 320 & 0.51 & 768.0 & 9.22 & 232.0 & 15.3 & 7.6 & $1.95 \mathrm{E}-10$ & $7.30 \mathrm{E}-12$ & 6.690 \\
\hline \multicolumn{12}{|c|}{ Hydraulic pump trip } \\
\hline s1 & $\begin{array}{l}394.3 \\
- \\
410.3 \\
\end{array}$ & 320 & 0.49 & 231.5 & 9.26 & 68.5 & 15.2 & 7.8 & 4.67E-10 & $2.63 \mathrm{E}-11$ & 6.726 \\
\hline $\mathrm{s} 2$ & 433.6 & 320 & 0.49 & 231.5 & 9.26 & 68.5 & 15.2 & 7.8 & $1.35 \mathrm{E}-09$ & $2.63 \mathrm{E}-11$ & 6.726 \\
\hline$t$ & 440 & 320 & 0.48 & 463.4 & 9.27 & 136.6 & 15.1 & 7.9 & $3.16 \mathrm{E}-12$ & $1.34 \mathrm{E}-11$ & 6.731 \\
\hline $\mathrm{u}$ & 505.6 & 319 & 0.48 & 464.4 & 9.29 & 135.6 & 15.2 & 7.9 & $3.76 \mathrm{E}-11$ & $1.38 \mathrm{E}-11$ & 6.740 \\
\hline $\mathrm{V}$ & 530 & 319 & 0.49 & 116.5 & 9.32 & 33.5 & 15.7 & 8.1 & $1.44 \mathrm{E}-11$ & $5.80 \mathrm{E}-11$ & 6.740 \\
\hline $\mathrm{w}$ & 532 & 319 & 0.29 & 8.32 & 4.16 & 1.68 & 16.5 & 11.7 & $1.12 \mathrm{E}-08$ & $2.23 \mathrm{E}-09$ & 6.787 \\
\hline $\mathrm{x}$ & 538.7 & 319 & 0.39 & 24.2 & 4.04 & 5.76 & 16.5 & 10.0 & $1.52 \mathrm{E}-09$ & $5.16 \mathrm{E}-10$ & 6.813 \\
\hline $\mathrm{y}$ & 559.3 & 320 & 0.50 & 46.6 & 9.33 & 13.4 & 16.5 & 8.3 & $2.81 \mathrm{E}-10$ & $1.63 \mathrm{E}-10$ & 6.831 \\
\hline $\mathrm{Z}$ & 601.7 & 319 & 0.48 & 93.5 & 9.35 & 26.5 & 16.3 & 8.5 & $8.88 \mathrm{E}-11$ & $8.41 \mathrm{E}-11$ & 6.845 \\
\hline aa & 630.7 & 319 & 0.49 & 236.6 & 9.47 & 63.4 & 17.7 & 9.0 & $3.90 \mathrm{E}-10$ & $4.17 \mathrm{E}-11$ & 6.877 \\
\hline$a b$ & 672.7 & 319 & 0.49 & 473.0 & 9.46 & 127.0 & 17.7 & 9.1 & $2.37 \mathrm{E}-10$ & $2.11 \mathrm{E}-11$ & 6.902 \\
\hline $\mathrm{ac}$ & 696.6 & 319 & 0.49 & 787.7 & 9.45 & 212.3 & 17.7 & 9.1 & $1.55 \mathrm{E}-10$ & $1.26 \mathrm{E}-11$ & 6.909 \\
\hline 1 & 821.9 & 319 & 0.50 & 12 & 12 & 7200 & 17.9 & 8.9 & $1.89 \mathrm{E}-11$ & $1.33 \mathrm{E}-12$ & 6.925 \\
\hline
\end{tabular}

$\mathrm{a}$ The CGR value was obtained from the later part of the test periods. 
(a)

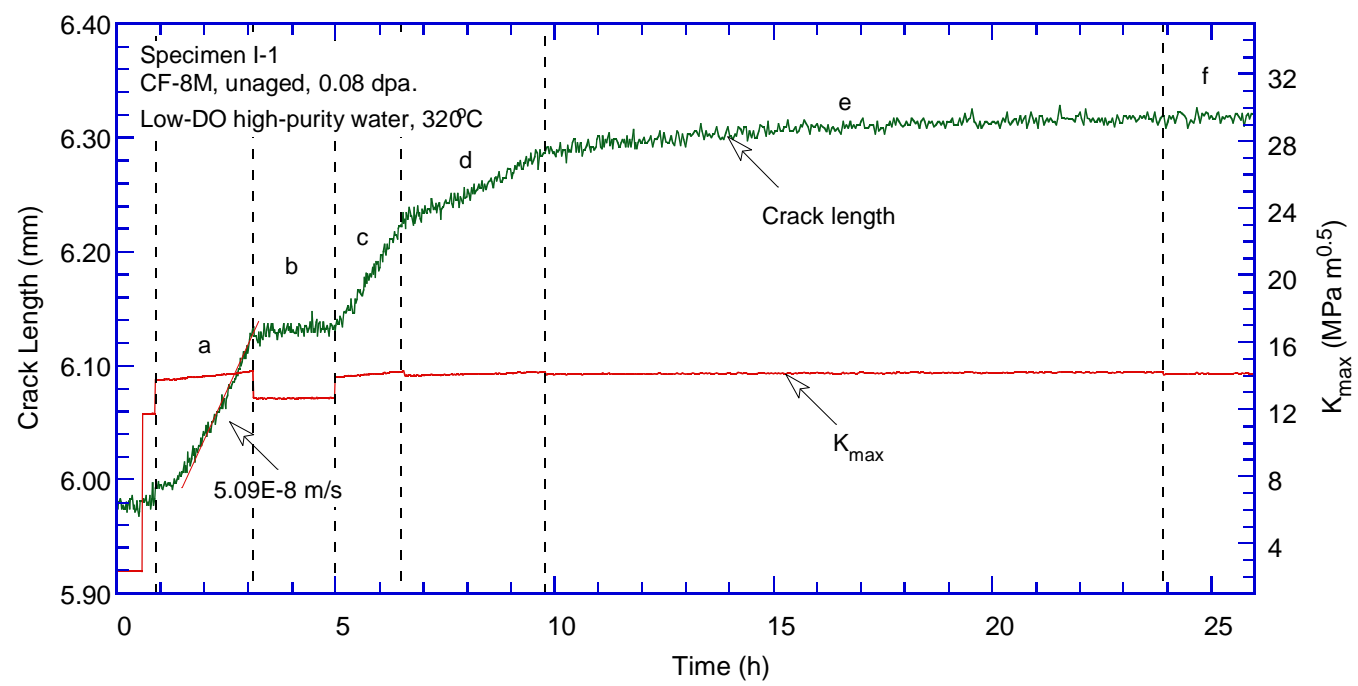

(b)

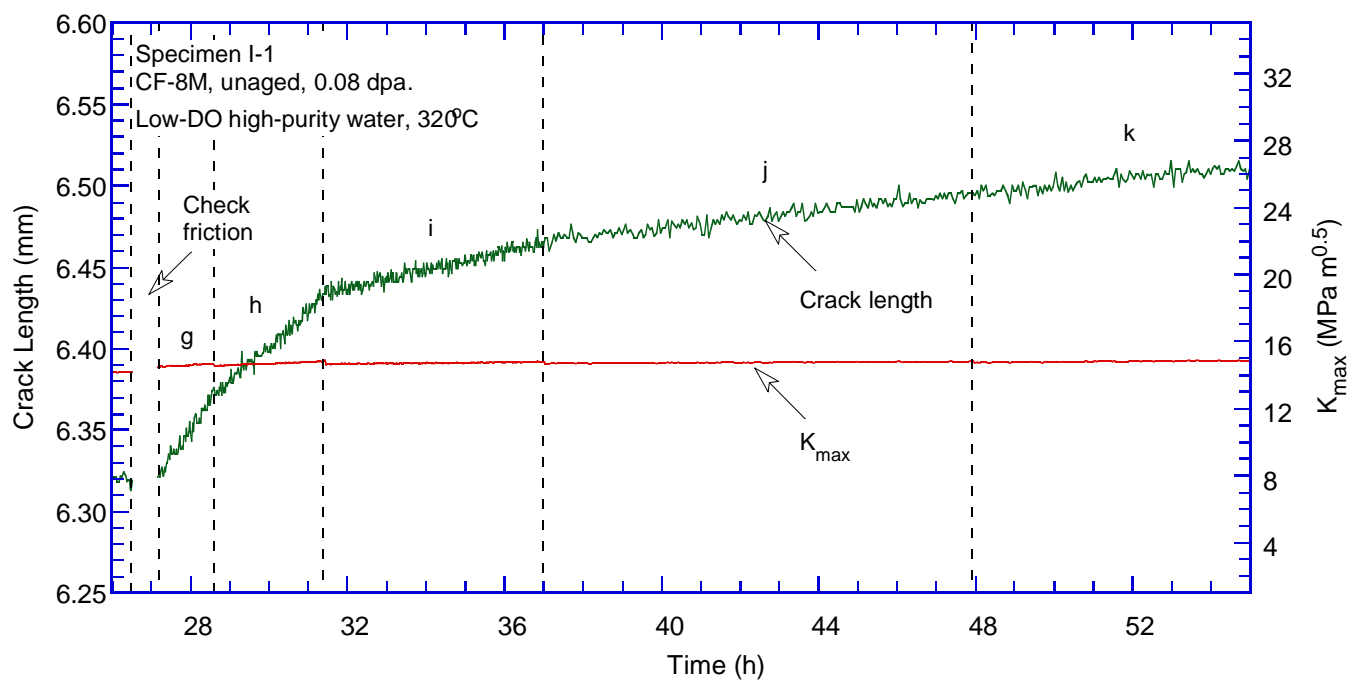

(c)

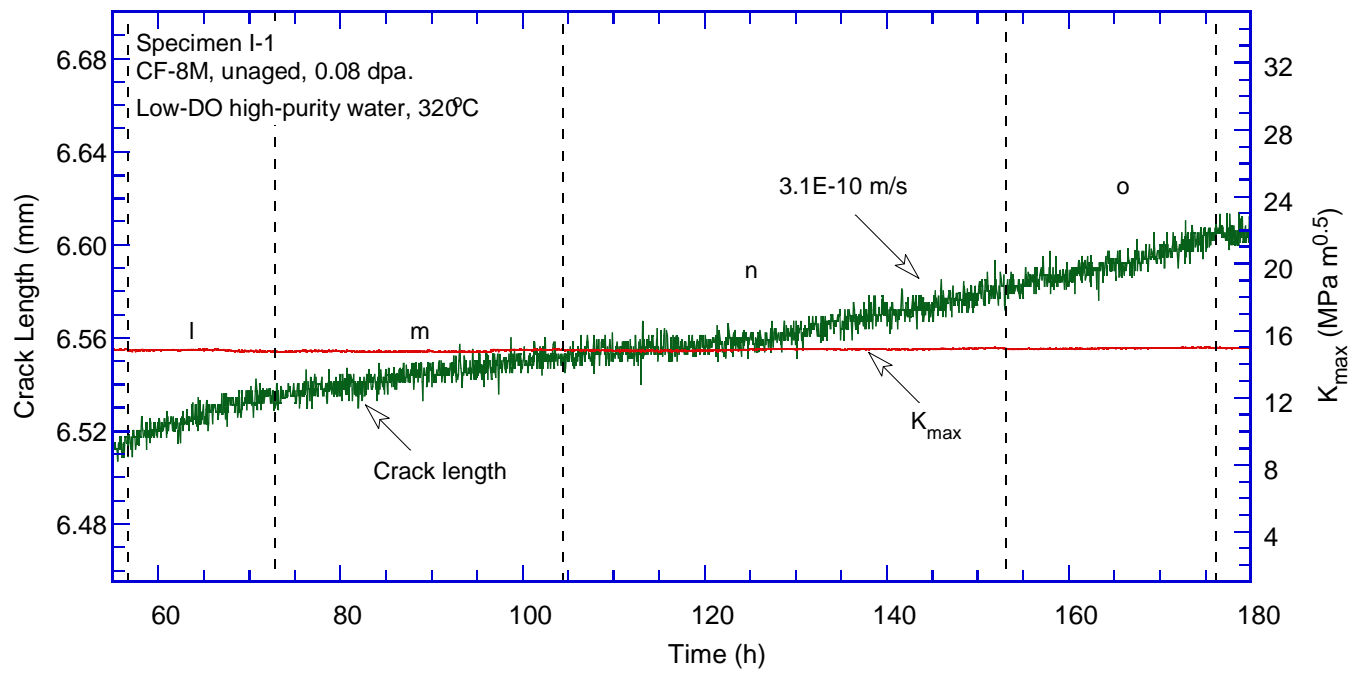

Figure 47. Crack-length-vs.-time plot for specimen I-1 (0.08-dpa unaged CF-8M with 28\% ferrite): test periods (a) a-f, (b) g-k, (c) l-o, (d) q-r, (e) s-v, (f) w-z, (g) aa-ac, and (h) 1. 
(d)

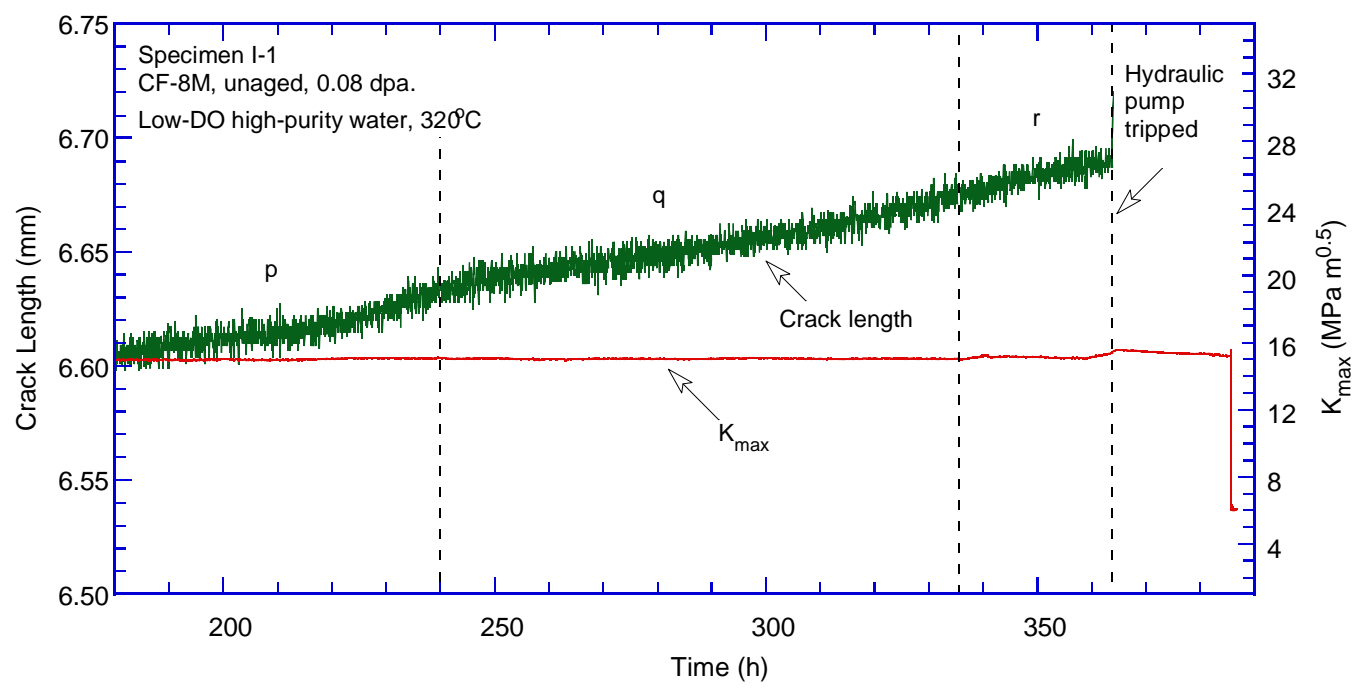

(e)

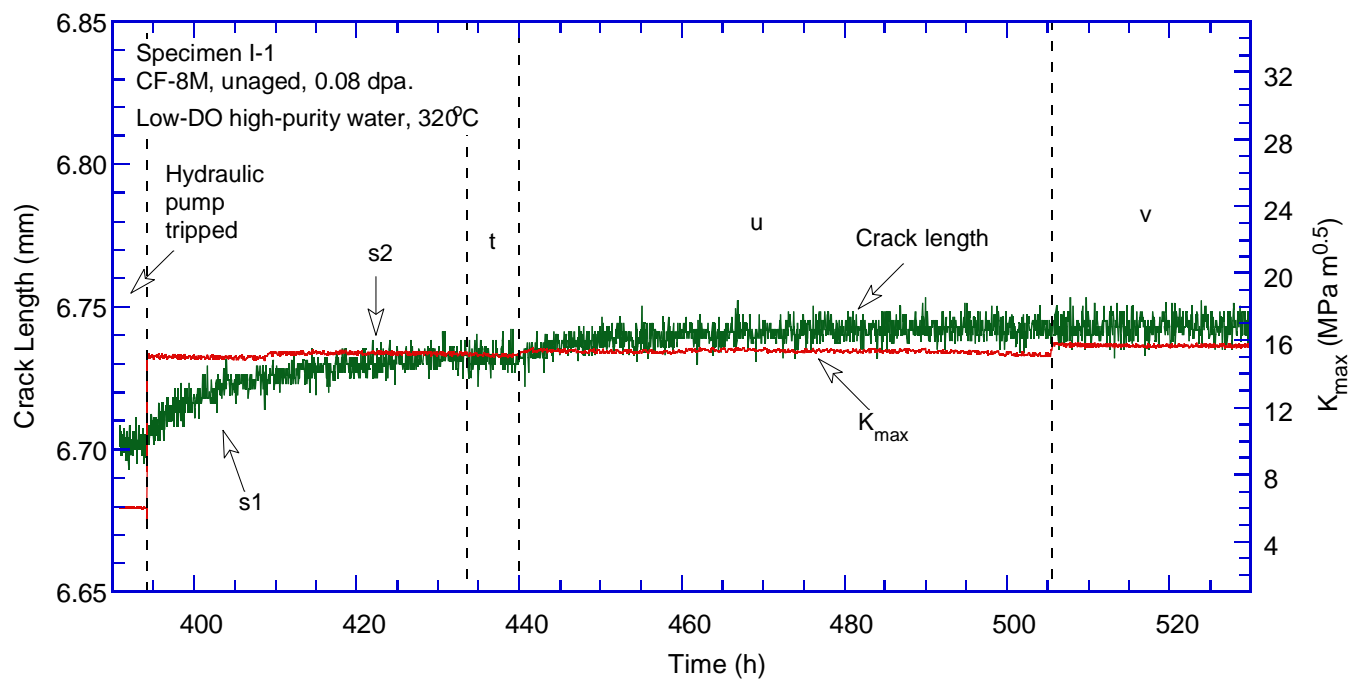

(f)

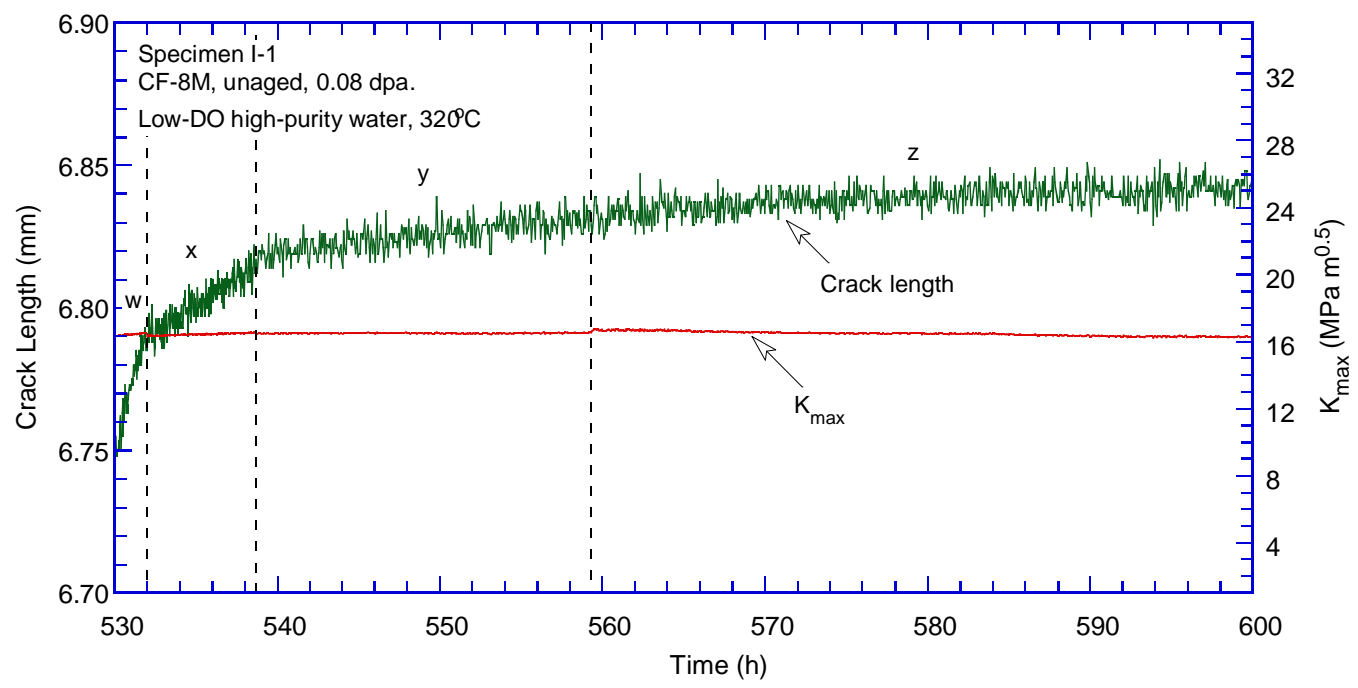

Figure 47. (Contd.) 
(g)

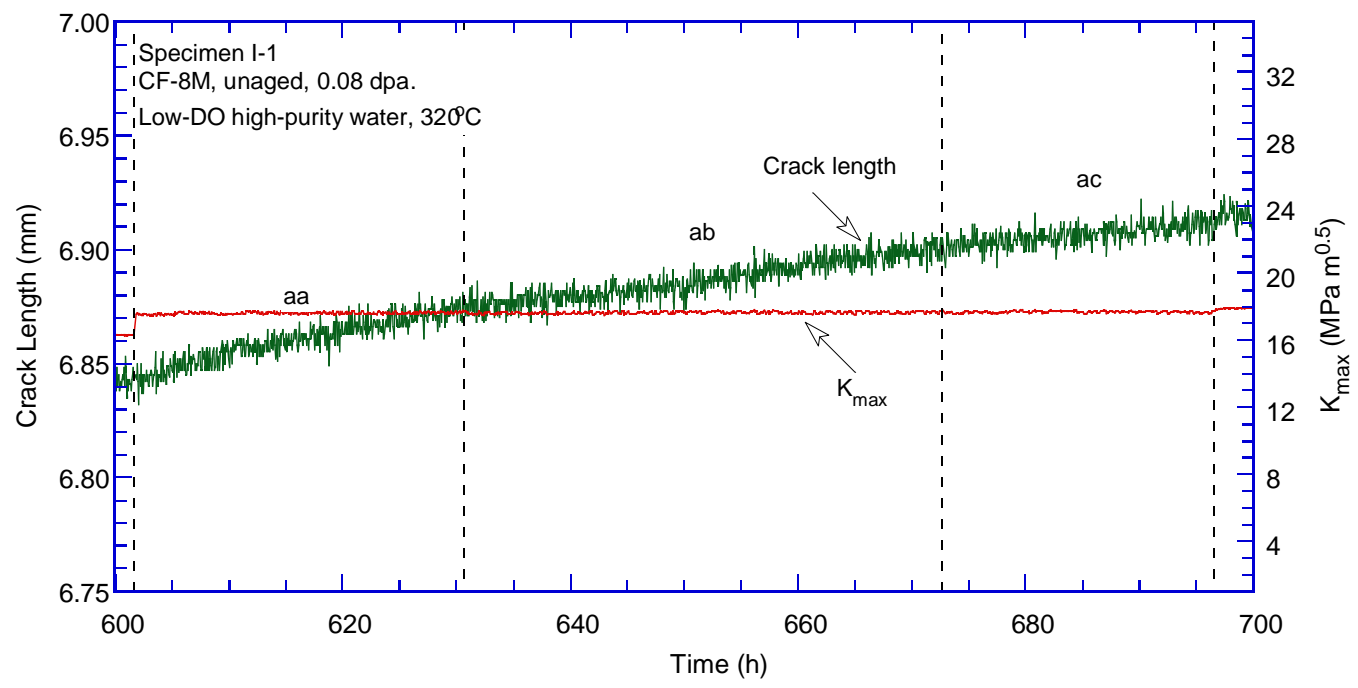

(h)

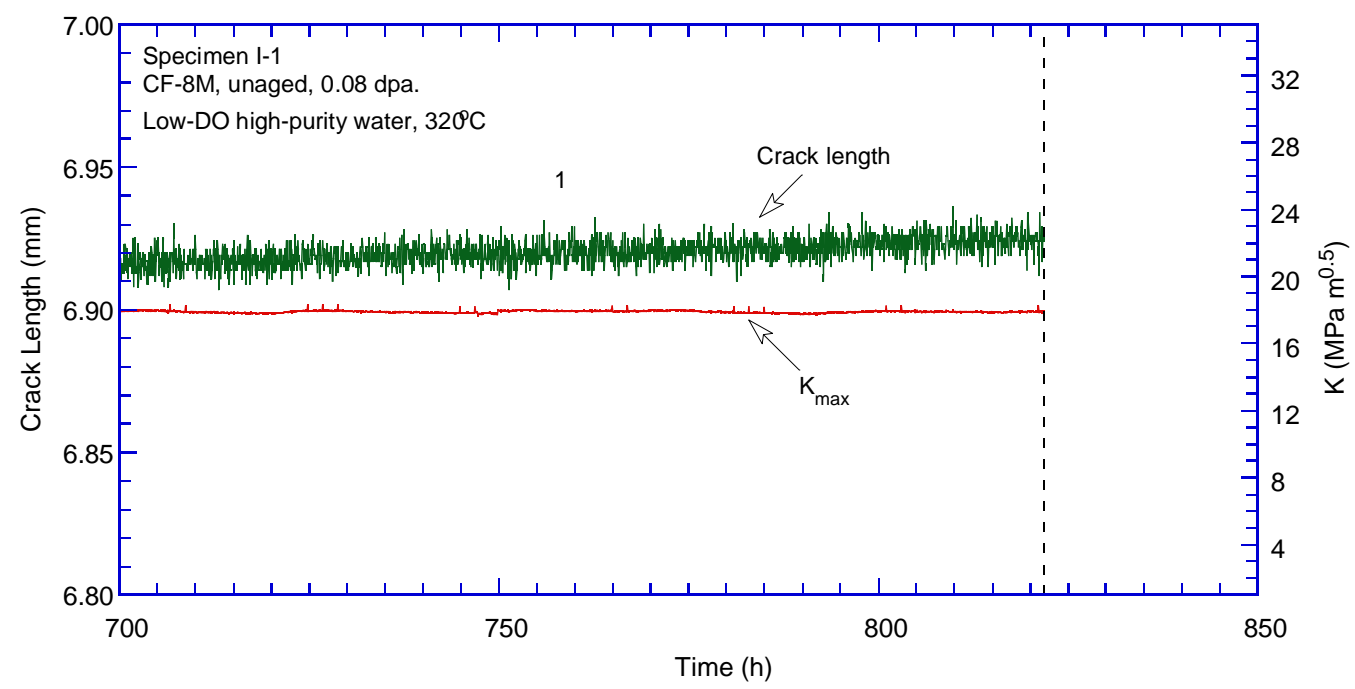

Figure 47. (Contd.) 


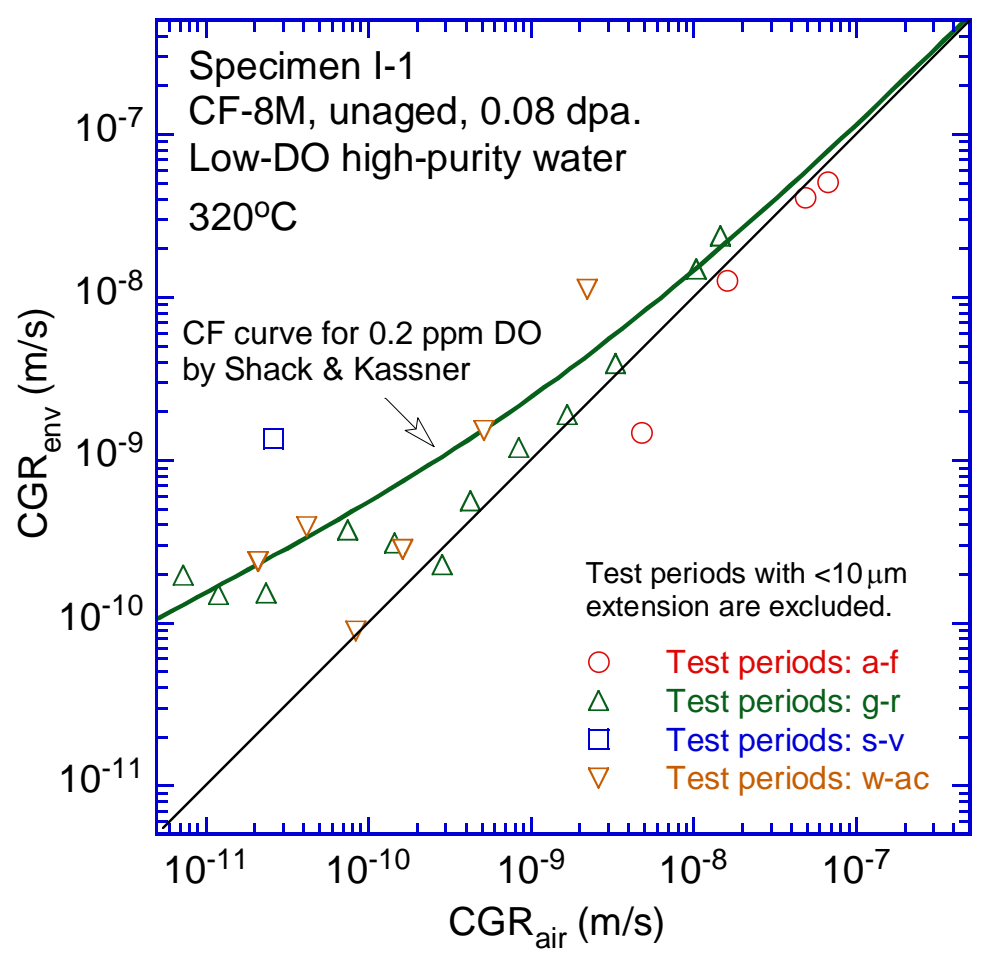

Figure 48. Cyclic CGRs of specimen I-1.

\section{Fracture toughness JR curve test}

After the CGR test, a fracture toughness JR curve test was performed on the same sample in the test environment. The obtained $\mathrm{J}$ and crack extension results are plotted in Fig. 49. A power-law fitting shows a $\mathrm{J}-\mathrm{R}$ correlation of $\mathrm{J}=336 \Delta \mathrm{a}^{0.66}$. The $\mathrm{J}$ value at the $0.2-\mathrm{mm}$ offset line is about $145 \mathrm{~kJ} / \mathrm{m}^{2}$. Note that the J-R curve data cannot be validated because one of the nine measurements of the final crack size was above the limit. Some data points above the $\mathrm{J}_{\max }$ were also used in the analysis. 


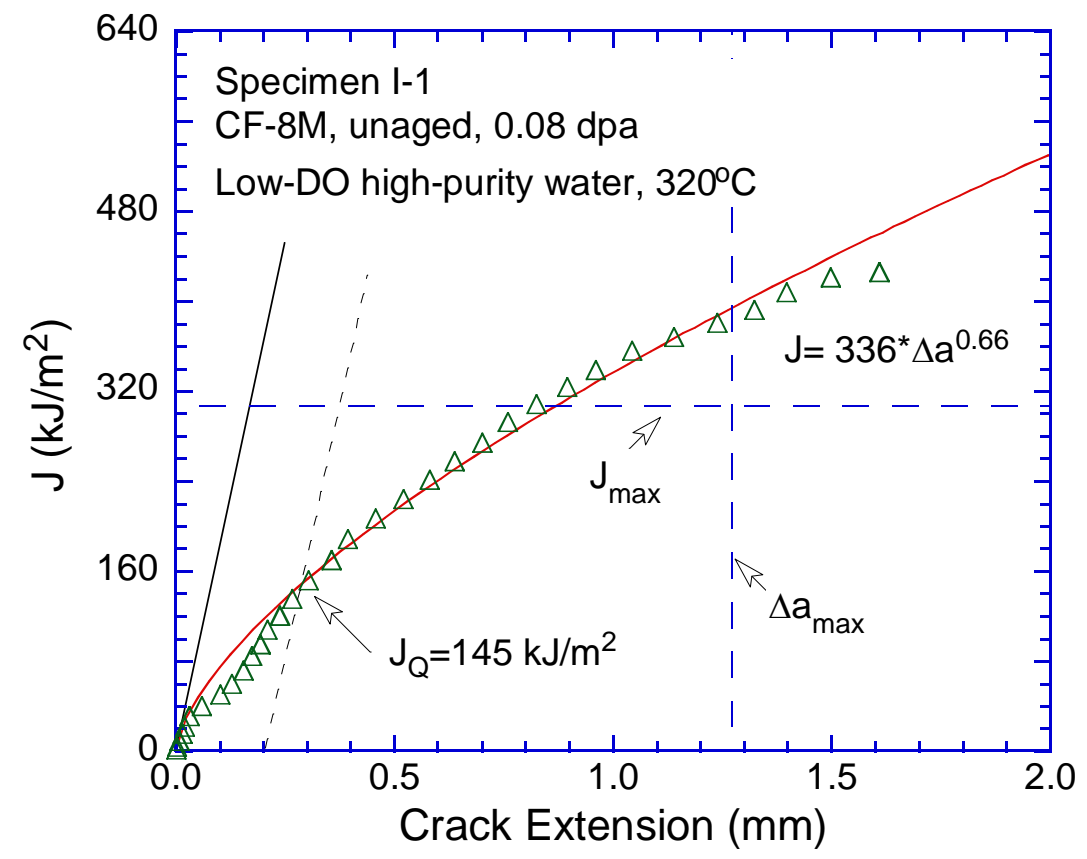

Figure 49. The JR curve of specimen I-1.

\section{$\underline{\text { Fractographic examination }}$}

Following the JR curve test, cyclic loading was applied at room temperature in an air atmosphere to break the remaining ligament. Figure 50 shows the fracture surface of specimen I-1. The crack front is relatively straight, indicating a well-controlled loading condition during the CGR test. The CGR region is flat, which shows a clear contrast from the heavily deformed plastic region in the JR test. Multiple secondary cracks perpendicular to the fracture surface can also be seen in the CGR test region. Figure 51 shows an enlarged view of the sample central line.

Fatigue cleavage cracking can be seen at the beginning of the CGR test. With the advance of the crack, cleavage cracking became less pronounced and the vermicular ferrite that formed at the core of casting dendrites started to appear (Fig. 52). At the end of the CGR test, little cleavage steps can be seen on the fracture surface (Fig. 53). In the JR test region, the fracture morphology was ductile dimple, suggesting heavy plastic deformation prior to fracture (Fig. 54). 


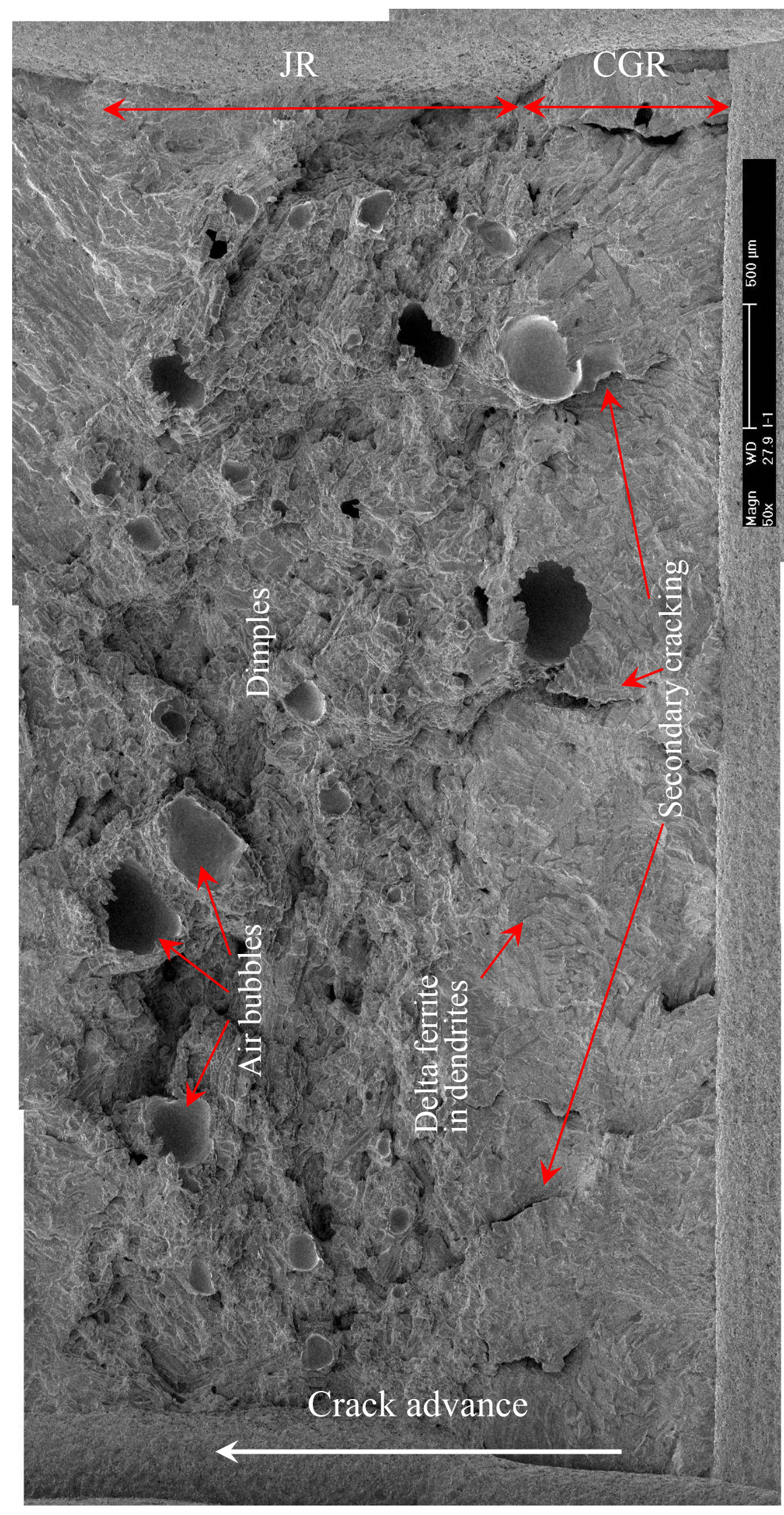

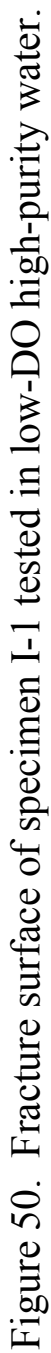




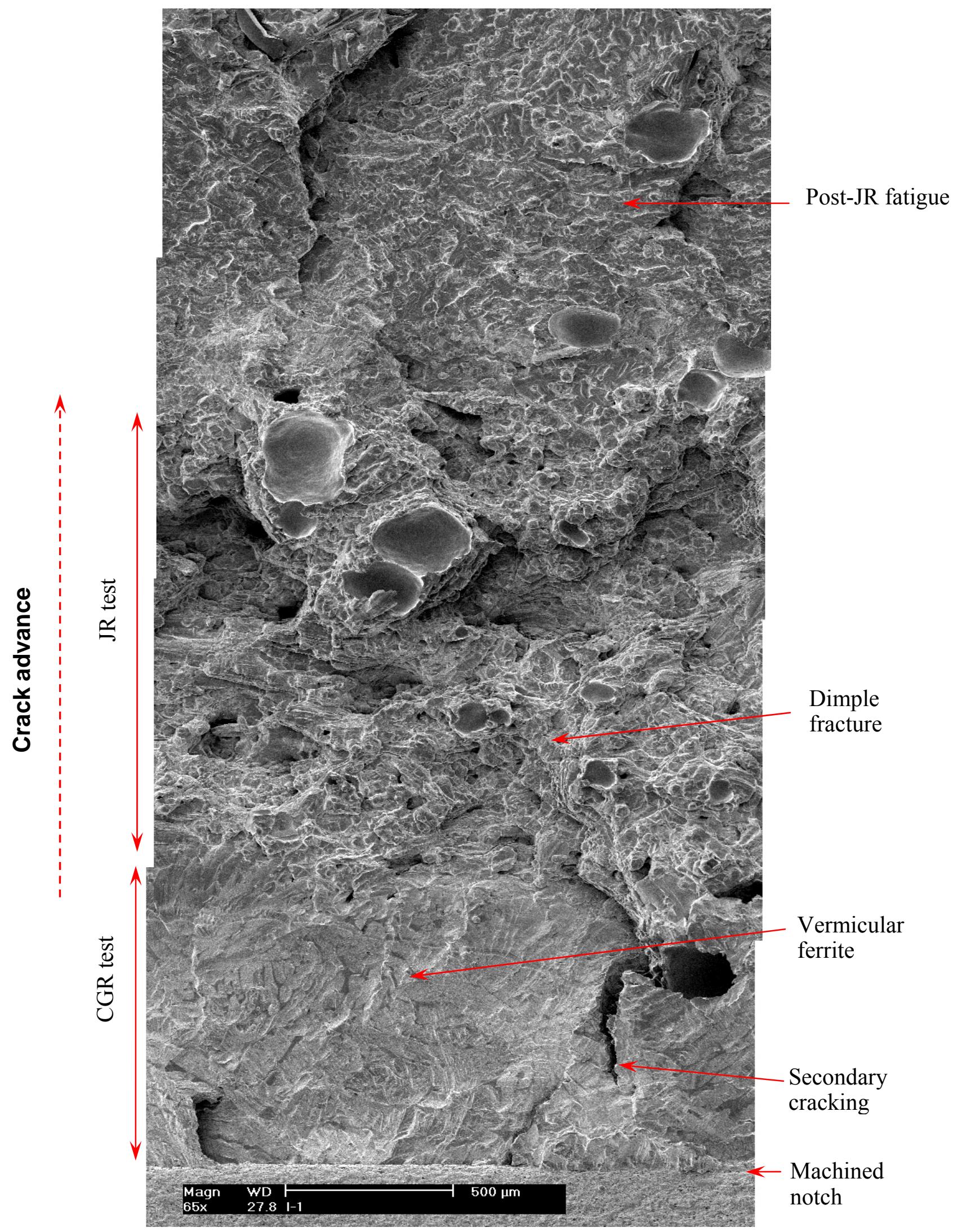

Figure 51. Fracture surface of specimen I-1 along the sample central line. 


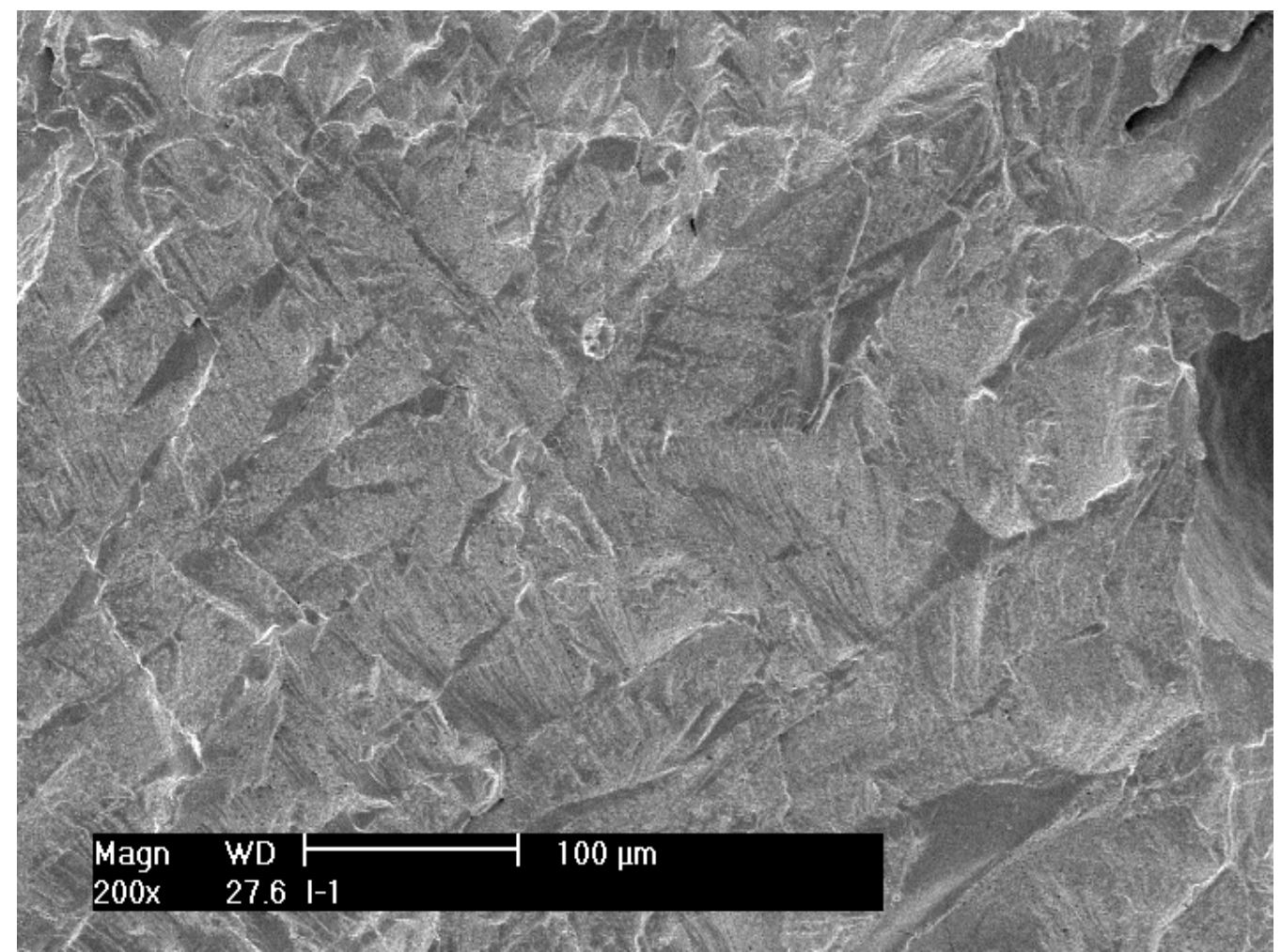

Figure 52. Precracking region in the CGR test of specimen I-1. Crack propagation from bottom to top.

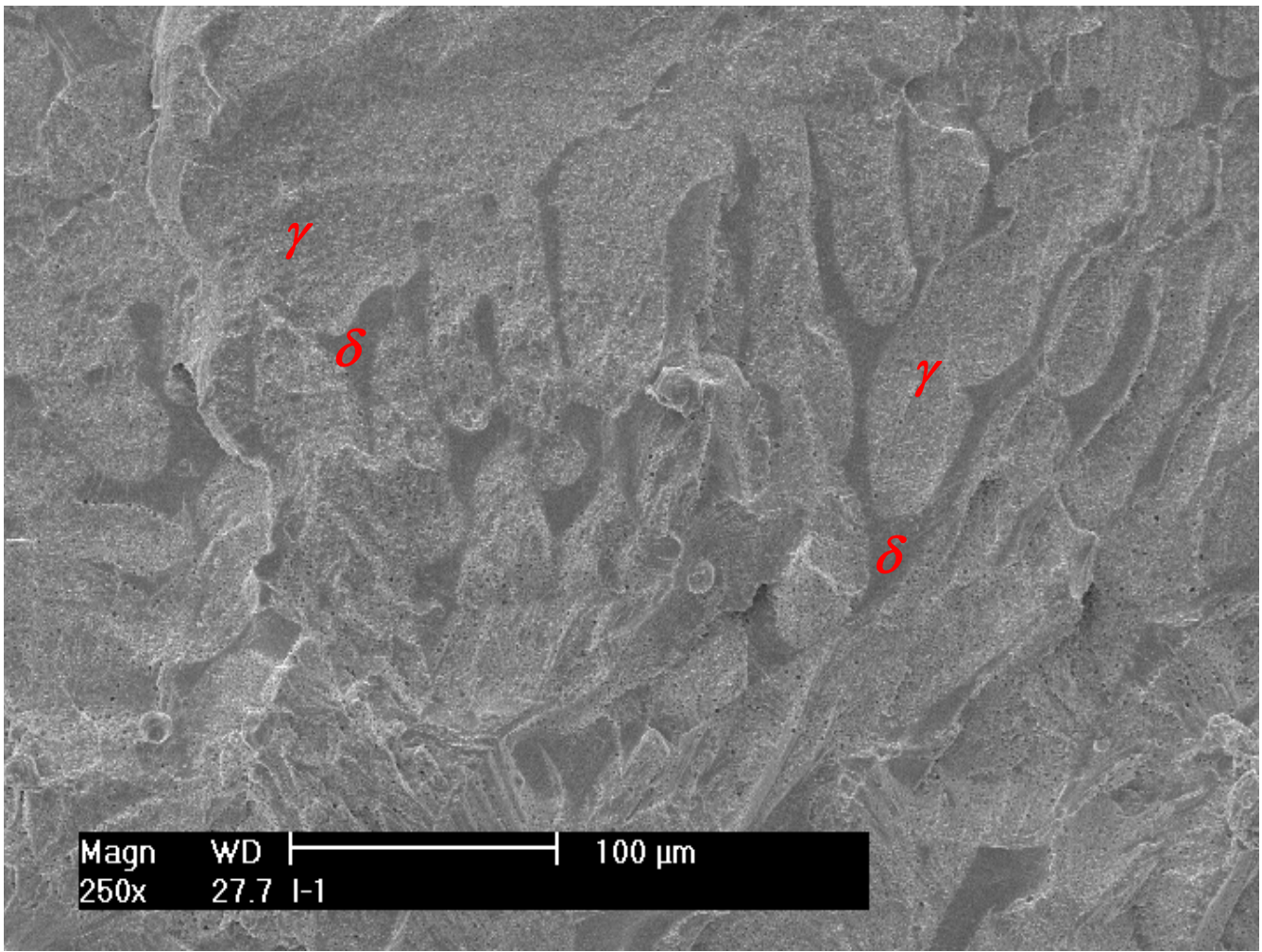

Figure 53. Fracture surface at the end of CGR test of specimen I-1. Crack propagation from bottom to top. 


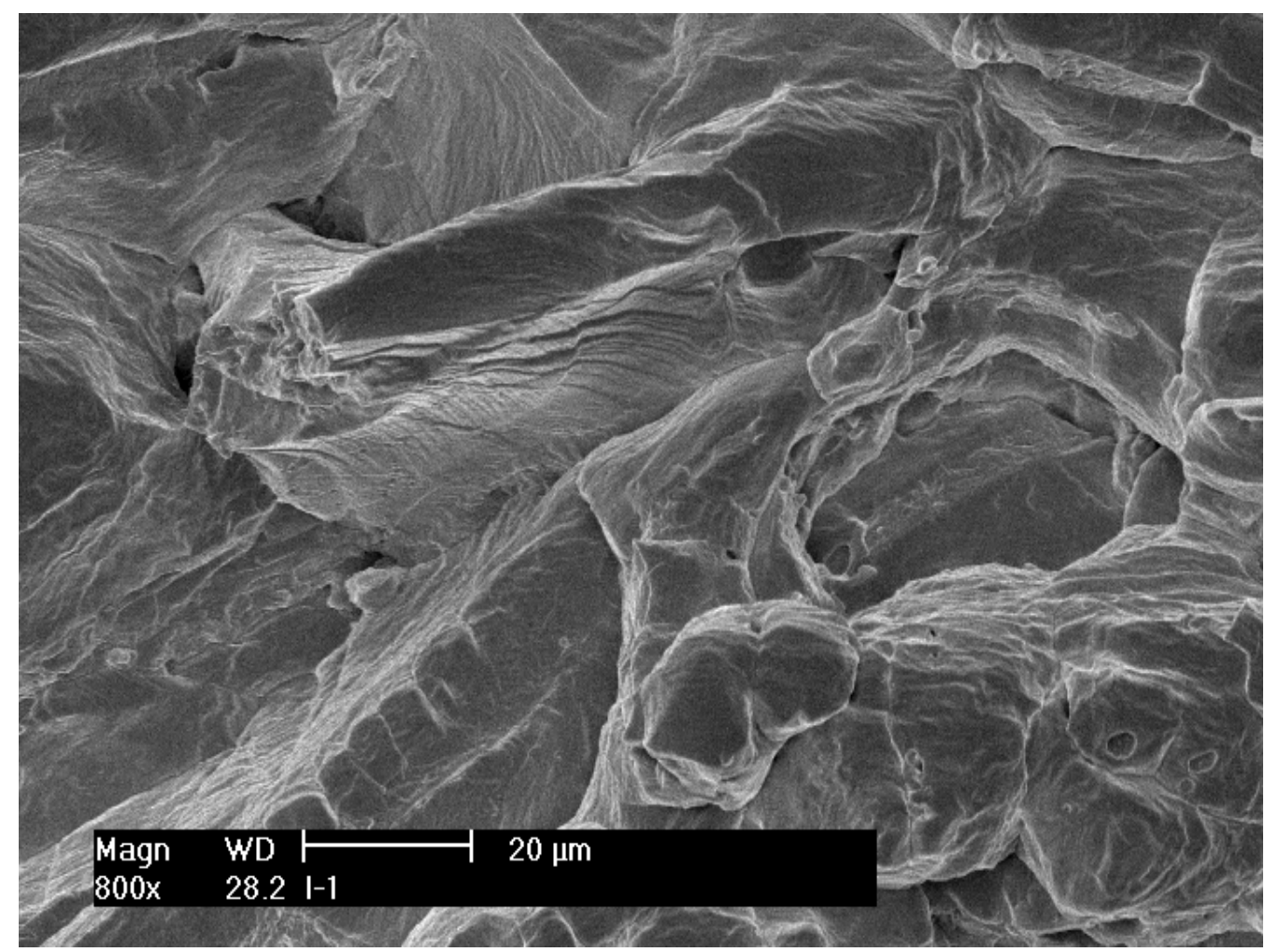

Figure 54. Heavily deformed microstructure in the JR test region of specimen I-1.

\subsubsection{Thermally Aged CF-8M CASS}

\section{$\underline{\text { Crack growth rate test }}$}

Specimen J-1 was the thermally aged version of specimen I-1, a CF-8M CASS with $28 \%$ ferrite. The sample was aged at $400^{\circ} \mathrm{C}$ for $10,000 \mathrm{hr}$ and then irradiated to $0.08 \mathrm{dpa}$. The test was performed in the low-DO high-purity water at $320^{\circ} \mathrm{C}$. The objective was to compare the results with those of the unaged CF-8M at the same dose. The CGR test conditions and results are summarized in Table 10, and a crack-length history plot is shown in Fig. 55.

Fatigue pre-cracking was carried out with a maximum stress intensity factor of $14-15 \mathrm{MPa} \mathrm{m}^{1 / 2}$, a load ratio of $0.2-0.3$, and frequency of $2 \mathrm{~Hz}$. After about $600-\mu \mathrm{m}$ crack extension, a stable crack growth was obtained in test period $h$, and the measured CGRs were very close to the fatigue line. Next, both the rise time and load ratio were gradually increased to promote environmentally enhanced cracking, and an elevated CGR became evident in test period $r$. Additional increases in rise time and load ratio produced a further environmental enhancement. By the end of test period $u$, the measured CGR was a factor of 25 higher than the fatigue growth rate. Figure 56 shows the cyclic CGRs obtained from this sample. The corrosion fatigue behavior of this thermally aged specimen seems to be similar to its unaged counterpart. Both of the CF-8M specimens show a higher degree of sensitivity to environmentally enhanced cracking than the CF-3 and CF-8 CASS used in this study. 
After pre-cracking, the test was set at constant load with PPU every $2 \mathrm{hr}$ in test period 1-a. A CGR of $1.810^{-11} \mathrm{~m} / \mathrm{s}$ was recorded at a stress intensity factor of $15.5 \mathrm{MPa} \mathrm{m}^{1 / 2}$. With a shorter holding time (PPU every $1 \mathrm{hr})$, a slightly higher CGR $\left(2.5 \times 10^{-11} \mathrm{~m} / \mathrm{s}\right)$ was obtained at the same stress intensity level. Next, the constant-load CGR (with PPUs) was measured at a higher stress intensity level ( $\left.19 \mathrm{MPa} \mathrm{m}{ }^{1 / 2}\right)$. A slightly higher CGR was once again observed with a shorter holding time (2-hr PPU in period 2-a and 1-hr PPU in period 2-b). When the PPU was removed in test period 2-c, the CGR became much lower. Constrained by test time, the CGR test was concluded after $10-\mu \mathrm{m}$ crack extension.

Figure 57 shows the SCC CGRs obtained from the unaged and aged CF-8M CASS in this study. The CGR values are all well below the NUREG-0313 disposition curve, as expected at this dose and ECP level. The unaged CF-8M may have performed slightly better. However, given the inherent uncertainty of CGR measurements, the difference in SCC CGRs of the aged and unaged CF-8M is insignificant.

Table 10. Crack growth rates of specimen J-1 (0.08-dpa aged CF-8M with $28 \% \delta$ ferrite) in a low-DO high-purity water environment.

\begin{tabular}{|c|c|c|c|c|c|c|c|c|c|c|c|}
\hline $\begin{array}{l}\text { Test } \\
\text { Period }\end{array}$ & $\begin{array}{l}\text { Test } \\
\text { Time, } \\
\mathrm{h}\end{array}$ & $\begin{array}{l}\text { Test } \\
\text { Temp., } \\
{ }^{\circ} \mathrm{C}\end{array}$ & $\begin{array}{l}\text { Load } \\
\text { Ratio }\end{array}$ & $\begin{array}{l}\text { Rise } \\
\text { Time, } \\
\mathrm{S}\end{array}$ & $\begin{array}{l}\text { Return } \\
\text { Time, } \\
\mathrm{s} \\
\end{array}$ & $\begin{array}{l}\text { Hold } \\
\text { Time, } \\
\mathrm{s} \\
\end{array}$ & $\begin{array}{l}\text { Kmax, } \\
\mathrm{MPa} \mathrm{m}^{1 / 2}\end{array}$ & $\begin{array}{l}\Delta \mathrm{K}, \\
\mathrm{MPa} \mathrm{m}^{1 / 2}\end{array}$ & $\begin{array}{l}\text { CGR in } \\
\text { Env., } \\
\mathrm{m} / \mathrm{s}\end{array}$ & $\begin{array}{l}\text { CGR in } \\
\text { Air, } \\
\mathrm{m} / \mathrm{s}\end{array}$ & $\begin{array}{l}\text { Crack } \\
\text { Length, } \\
\mathrm{mm} \\
\end{array}$ \\
\hline Start & 0.4 & & & & & & & & & & 5.970 \\
\hline $\mathrm{a}$ & 2.2 & 320 & 0.20 & 0.22 & 0.22 & 0.03 & 14.2 & 11.3 & $6.53 \mathrm{E}-09$ & $6.82 \mathrm{E}-08$ & 5.990 \\
\hline $\mathrm{b}$ & 3.6 & 320 & 0.20 & 0.22 & 0.22 & 0.03 & 16.6 & 13.2 & $5.35 \mathrm{E}-08$ & $1.13 \mathrm{E}-07$ & 6.111 \\
\hline $\mathrm{c}$ & 6.3 & 320 & 0.30 & 0.43 & 0.43 & 0.07 & 15.5 & 10.8 & $1.57 \mathrm{E}-08$ & $3.37 \mathrm{E}-08$ & 6.183 \\
\hline $\mathrm{d}$ & 8.6 & 320 & 0.30 & 0.21 & 0.21 & 0.04 & 14.5 & 10.1 & $9.37 \mathrm{E}-09$ & $5.43 \mathrm{E}-08$ & 6.217 \\
\hline $\mathrm{e}$ & 23.8 & 320 & 0.30 & 4.29 & 4.29 & 0.71 & 14.4 & 10.0 & $2.97 \mathrm{E}-10$ & $2.67 \mathrm{E}-09$ & 6.225 \\
\hline$f$ & 25.3 & 320 & 0.30 & 0.22 & 0.22 & 0.03 & 15.9 & 11.1 & $7.02 \mathrm{E}-08$ & $7.34 \mathrm{E}-08$ & 6.381 \\
\hline $\mathrm{g}^{\mathrm{a}}$ & 28.7 & 320 & 0.30 & 0.43 & 0.43 & 0.07 & 15.0 & 10.4 & $2.98 \mathrm{E}-08$ & $3.05 \mathrm{E}-08$ & 6.494 \\
\hline $\mathrm{h}$ & 33.5 & 320 & 0.40 & 0.83 & 0.83 & 0.17 & 15.1 & 9.0 & $1.24 \mathrm{E}-08$ & $1.08 \mathrm{E}-08$ & 6.587 \\
\hline $\mathrm{i}$ & 37.1 & 320 & 0.45 & 1.64 & 1.64 & 0.36 & 15.1 & 8.2 & $6.15 \mathrm{E}-09$ & $4.31 \mathrm{E}-09$ & 6.620 \\
\hline $\mathrm{j}$ & 48.5 & 320 & 0.52 & 3.98 & 3.98 & 1.02 & 15.0 & 7.2 & $6.21 \mathrm{E}-10$ & $1.20 \mathrm{E}-09$ & 6.632 \\
\hline $\mathrm{k}^{\mathrm{a}}$ & 51.5 & 320 & 0.45 & 0.82 & 0.82 & 0.18 & 15.2 & 8.3 & $1.20 \mathrm{E}-08$ & 8.81E-09 & 6.669 \\
\hline 1 & 54.9 & 320 & 0.50 & 1.60 & 1.60 & 0.40 & 15.1 & 7.5 & 4.29E-09 & $3.41 \mathrm{E}-09$ & 6.692 \\
\hline $\mathrm{m}$ & 61.7 & 320 & 0.50 & 4.00 & 4.00 & 1.00 & 15.1 & 7.6 & $1.80 \mathrm{E}-09$ & 1.39E-09 & 6.709 \\
\hline $\mathrm{n}$ & 72.2 & 320 & 0.55 & 7.82 & 3.91 & 2.18 & 15.0 & 6.8 & $2.40 \mathrm{E}-10$ & $5.15 \mathrm{E}-10$ & 6.715 \\
\hline $\mathrm{o}$ & 80.8 & 320 & 0.50 & 7.99 & 3.99 & 2.01 & 15.2 & 7.5 & $9.35 \mathrm{E}-10$ & $6.91 \mathrm{E}-10$ & 6.731 \\
\hline $\mathrm{p}$ & 103.7 & 319 & 0.50 & 24.0 & 9.60 & 5.99 & 15.3 & 7.7 & $5.52 \mathrm{E}-10$ & $2.41 \mathrm{E}-10$ & 6.758 \\
\hline$q$ & 125.6 & 320 & 0.50 & 47.9 & 9.59 & 12.1 & 15.5 & 7.7 & $6.71 \mathrm{E}-10$ & $1.23 \mathrm{E}-10$ & 6.794 \\
\hline$r$ & 147.8 & 319 & 0.55 & 93.9 & 9.39 & 26.1 & 15.6 & 7.0 & $4.36 \mathrm{E}-10$ & $4.81 \mathrm{E}-11$ & 6.819 \\
\hline $\mathrm{s}$ & 176.2 & 319 & 0.60 & 228.8 & 9.15 & 71.2 & 15.6 & 6.3 & $1.59 \mathrm{E}-10$ & $1.44 \mathrm{E}-11$ & 6.833 \\
\hline $\mathrm{t}$ & 216.7 & 319 & 0.60 & 381.2 & 9.15 & 118.8 & 15.6 & 6.3 & $1.80 \mathrm{E}-10$ & $8.77 \mathrm{E}-12$ & 6.853 \\
\hline $\mathrm{u}$ & 249.4 & 319 & 0.60 & 762.8 & 9.15 & 237.2 & 15.8 & 6.4 & $1.32 \mathrm{E}-10$ & $4.47 \mathrm{E}-12$ & 6.864 \\
\hline $1-a$ & 317.5 & 319 & 0.60 & 12 & 12 & 7200 & 15.5 & 6.2 & $1.79 \mathrm{E}-11$ & $4.39 \mathrm{E}-13$ & 6.874 \\
\hline $1-b$ & 365.2 & 319 & 0.60 & 12 & 12 & 3600 & 15.6 & 6.3 & $2.47 \mathrm{E}-11$ & 8.97E-13 & 6.878 \\
\hline $2-\mathrm{a}^{\mathrm{a}}$ & 416.7 & 319 & 0.60 & 12 & 12 & 7200 & 19.0 & 7.6 & $5.51 \mathrm{E}-11$ & $8.49 \mathrm{E}-13$ & 6.899 \\
\hline $2-b$ & 466 & 320 & 0.60 & 12 & 12 & 3600 & 18.9 & 7.6 & $6.42 \mathrm{E}-11$ & $1.68 \mathrm{E}-12$ & 6.910 \\
\hline 2-c & 503.9 & 320 & 1 & - & - & - & 18.9 & - & $2.02 \mathrm{E}-12$ & - & 6.911 \\
\hline
\end{tabular}

$\mathrm{a}$ The CGR value was obtained from the later part of the test periods. 
(a)

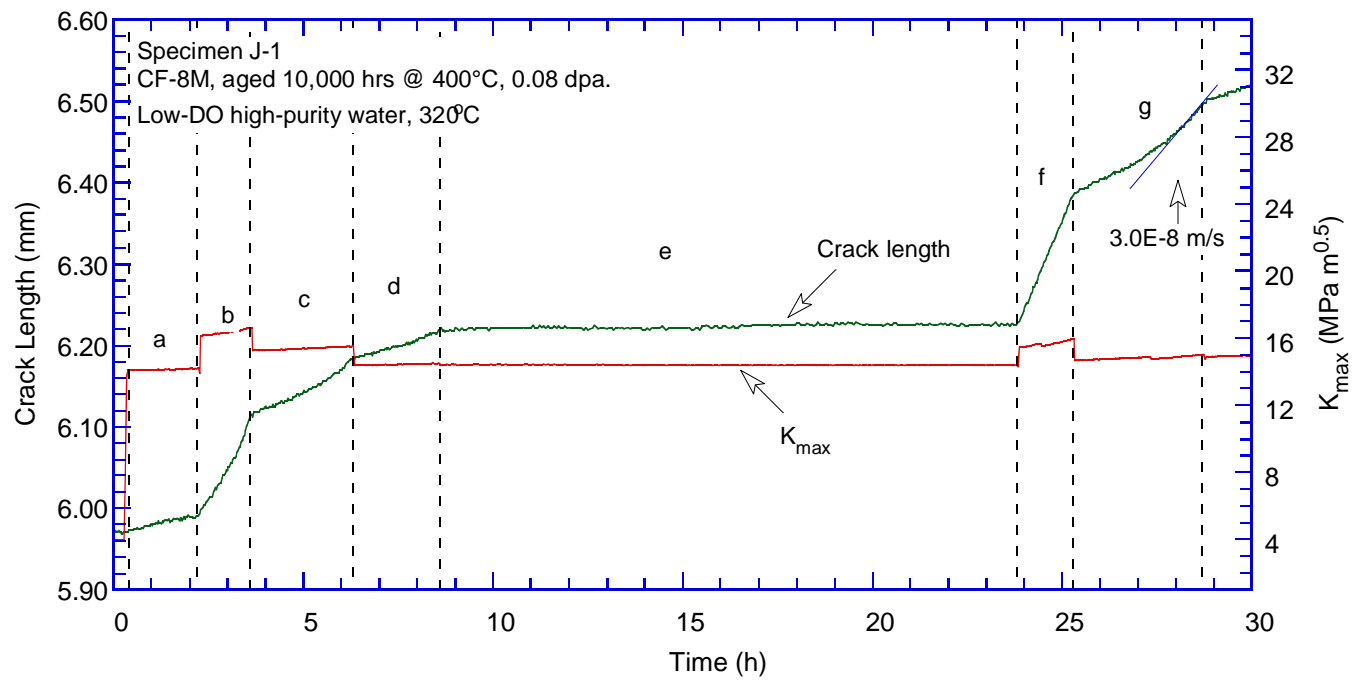

(b)

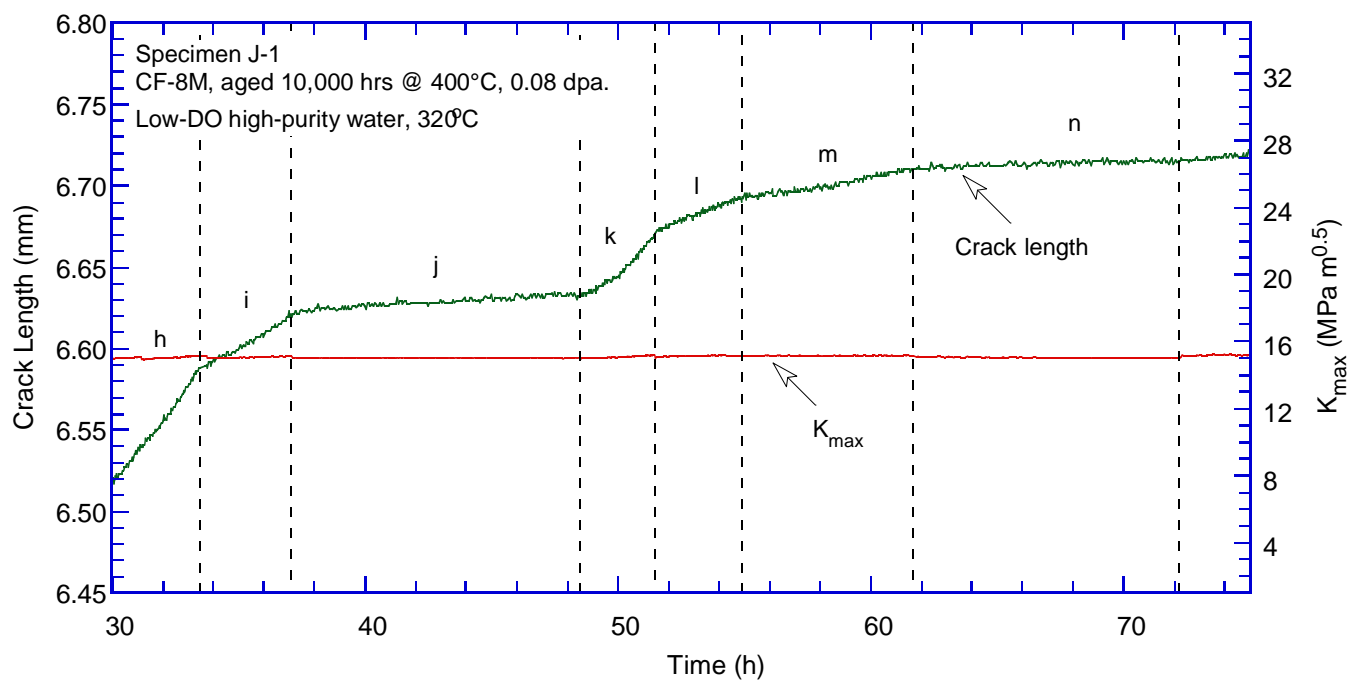

(c)

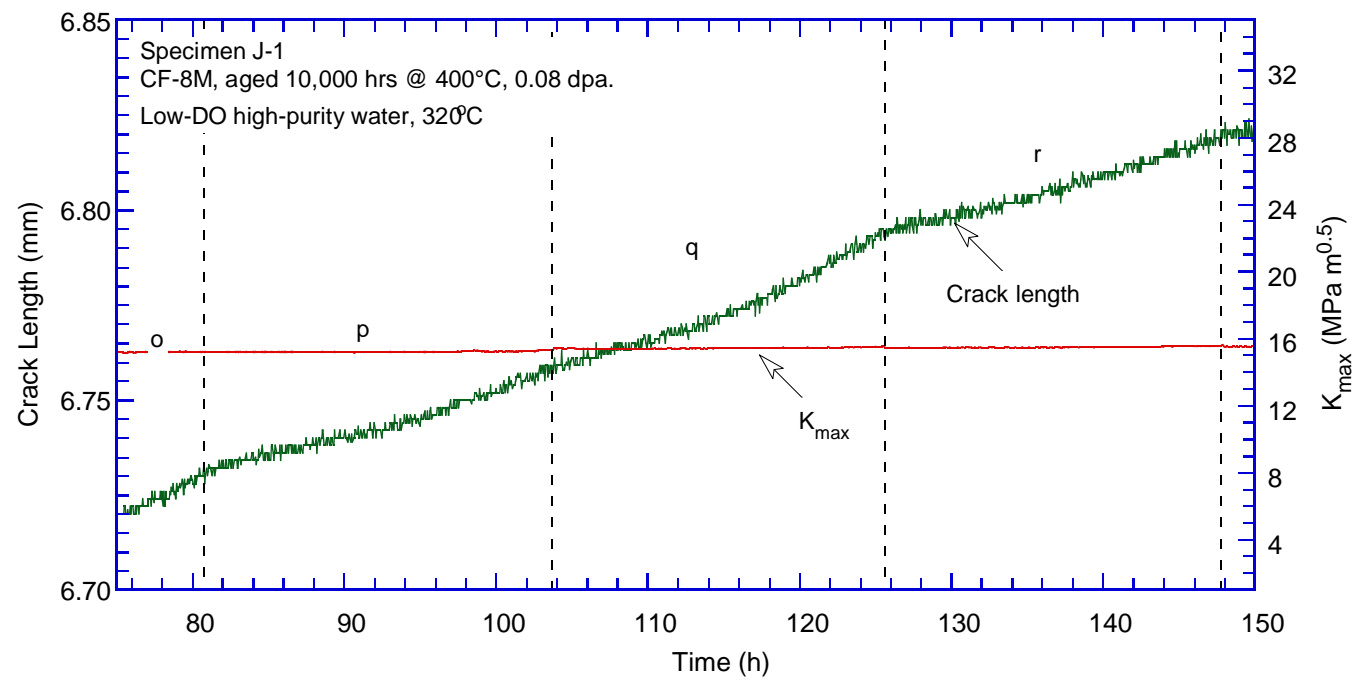

Figure 55. Crack-length-vs.-time plot for specimen J-1 (0.08-dpa aged CF-8M with 28\% ferrite): test periods (a) a-g, (b) h-n, (c) o-r, (d) s-u, (e) 1, and (f) 2. 
(d)

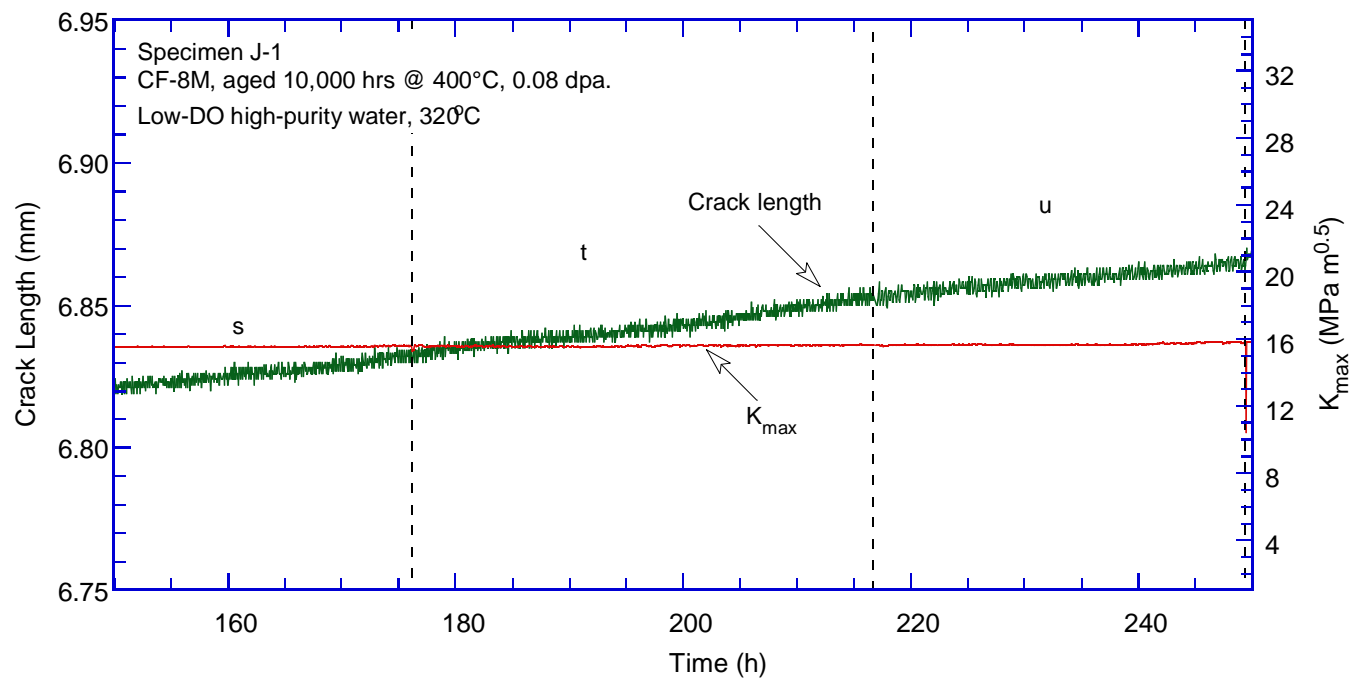

(e)

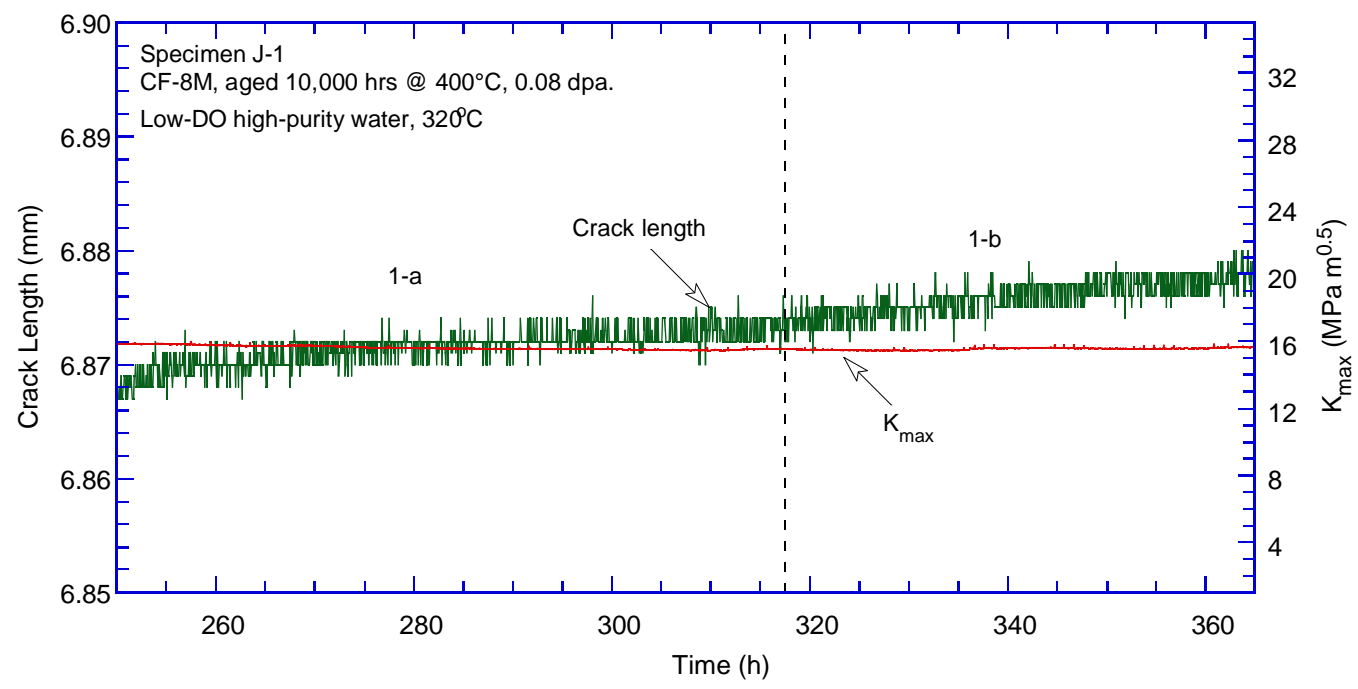

(f)

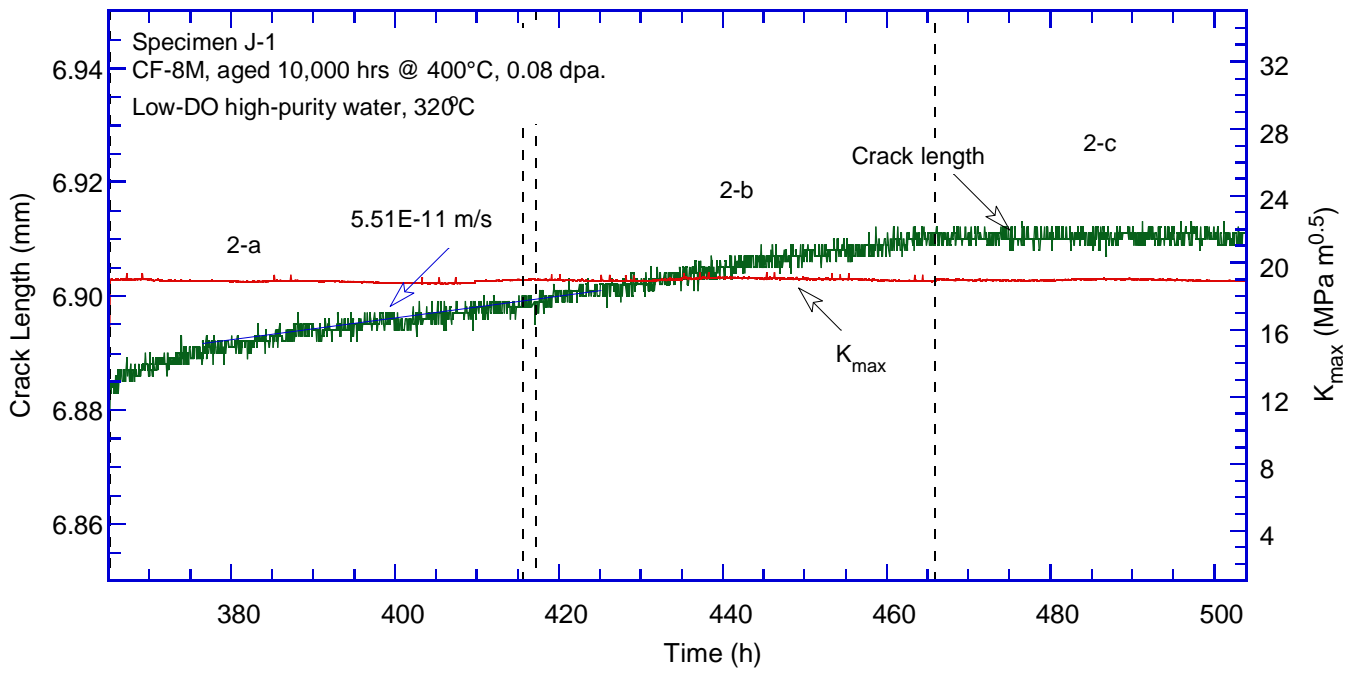

Figure 55. (Contd.) 


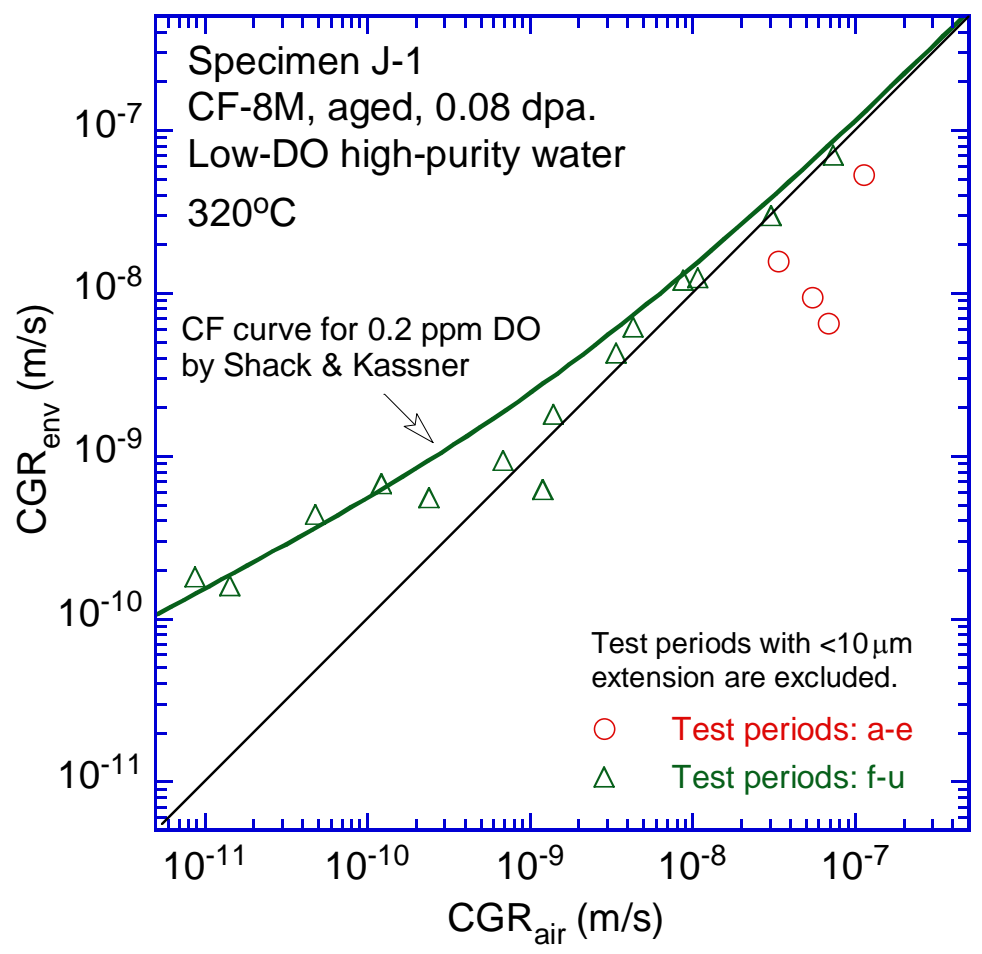

Figure 56. Cyclic CGRs of specimen J-1.

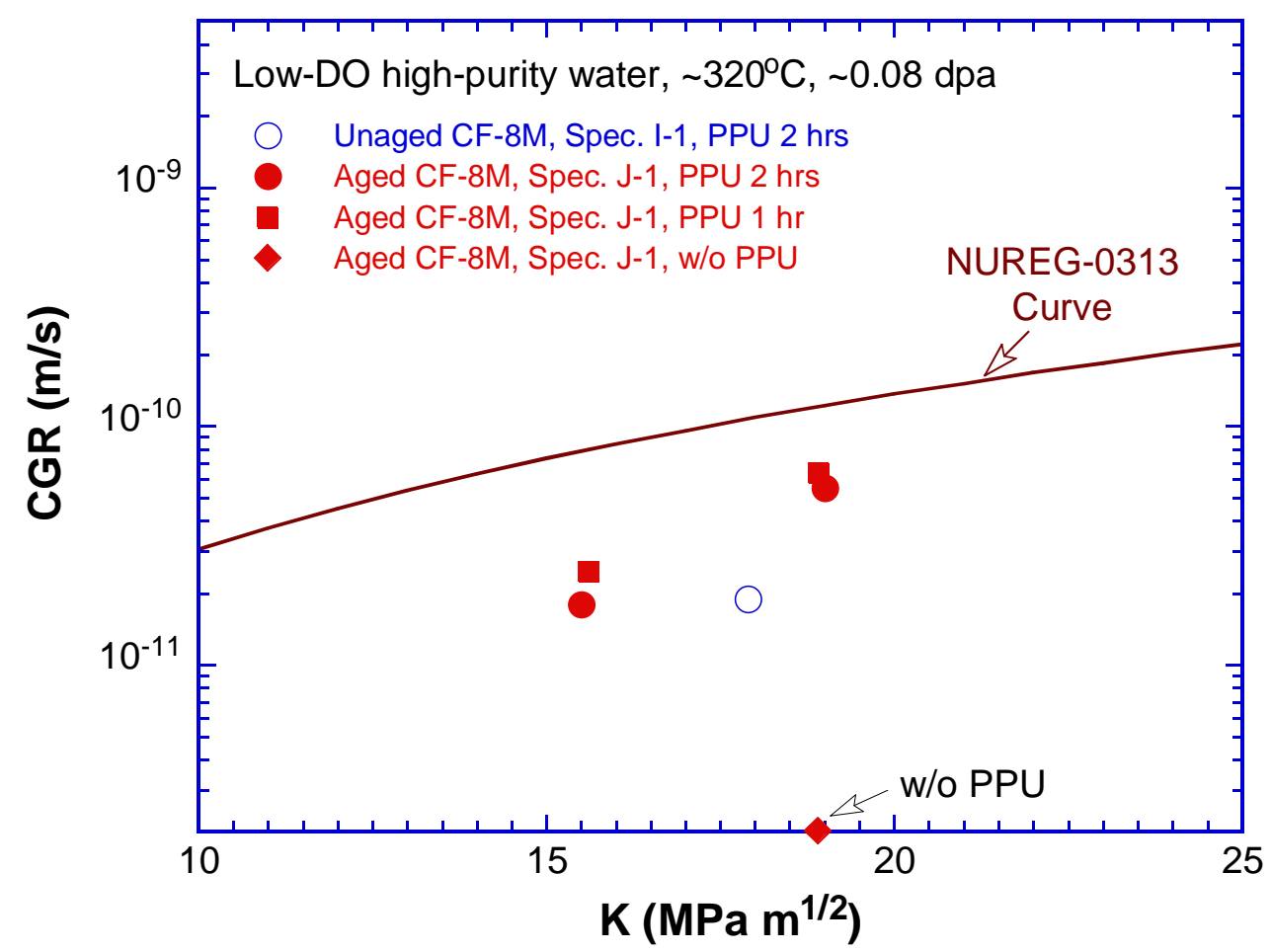

Figure 57. SCC CGRs of unaged and aged CF-8M CASS, irradiated to $0.08 \mathrm{dpa}$. 


\section{Fracture toughness JR curve test}

After the CGR test, a fracture toughness JR curve test was carried out on the same sample in the test environment. The $\mathrm{J}$ and crack extension results are shown in Fig. 58. A power-law fitting of the data shows a JR relationship of $J=259 \Delta \mathrm{a}^{0.64}$, which yields a $\mathrm{J}$ value of $106 \mathrm{~kJ} / \mathrm{m}^{2}$ at the 0.2 $\mathrm{mm}$ offset line. All $\mathrm{J}$ values obtained in this sample were below the $\mathrm{J}_{\max }$ limit. However, one of the nine measurements of the final crack size still exceeded the limit. Thus, the J-R curve cannot be validated.

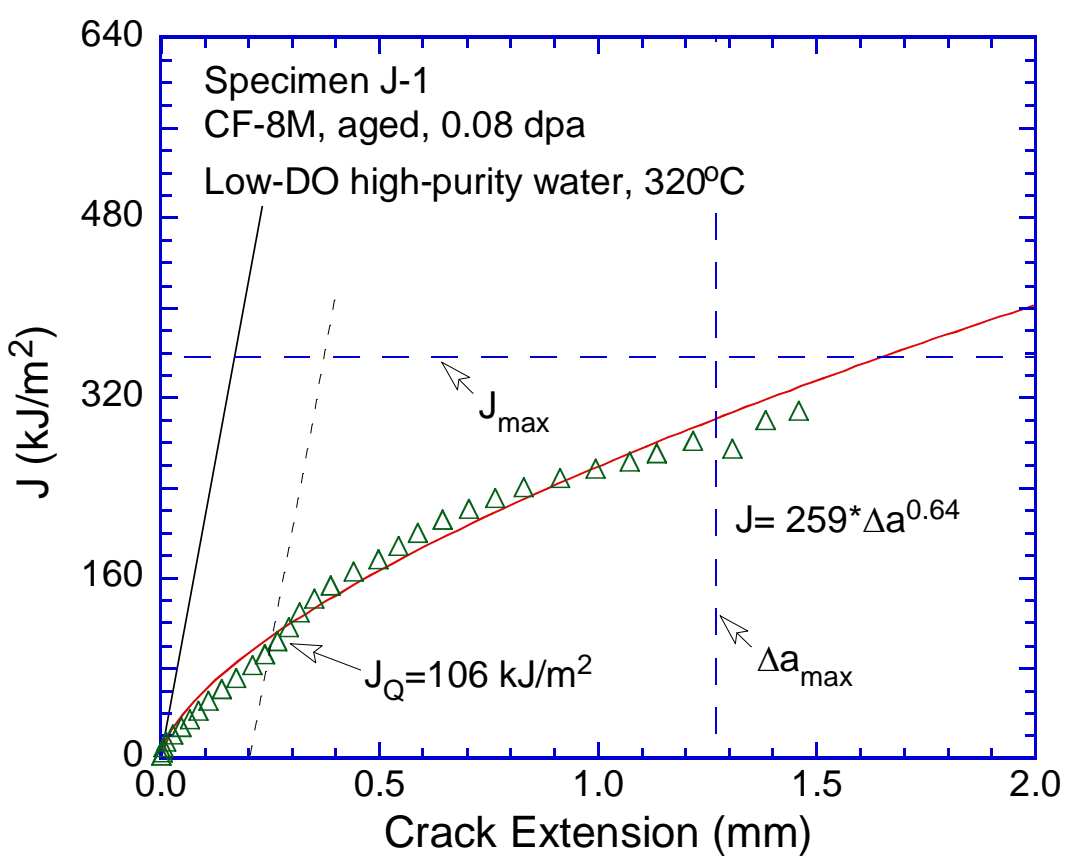

Figure 58. The JR curve of specimen J-1.

\section{$\underline{\text { Fractographic examination }}$}

The fracture surface of specimen J-1 was examined with replicas. Figure 59 shows the entire fracture surface. Two distinct fracture regions, CGR and JR test areas, can be clearly identified. The crack front of the CGR test is straight, indicating a well-controlled loading condition during the test. The CGR region is relatively flat and shows a clear contrast from the heavily deformed JR test region. Similar to the unaged CF-8M (specimen I-1), secondary cracks can be seen on the fracture surface.

Figure 60 shows an enlarged view of the fracture surface along the sample central line. Ferrite phase at the casting dendrite cores can be seen throughout the entire CGR region. Transgranular cleavage cracking is clearly visible in the pre-cracking region, as shown in Fig. 61. As the crack advances, cleavage steps became less pronounced in some areas, and little plastic deformation could be seen within the ferrites phase compared to the surrounding austenite phase (Fig. 62). In some other areas however, cleavage cracking remained the dominant fracture mode (Fig. 63). In 
the JR test region, the fracture morphology was mostly ductile dimples, suggesting heavy plastic flow during the JR test. In some areas, fracture occurred along the ferrite core of the columnar dendrites, as shown in Fig. 64. 


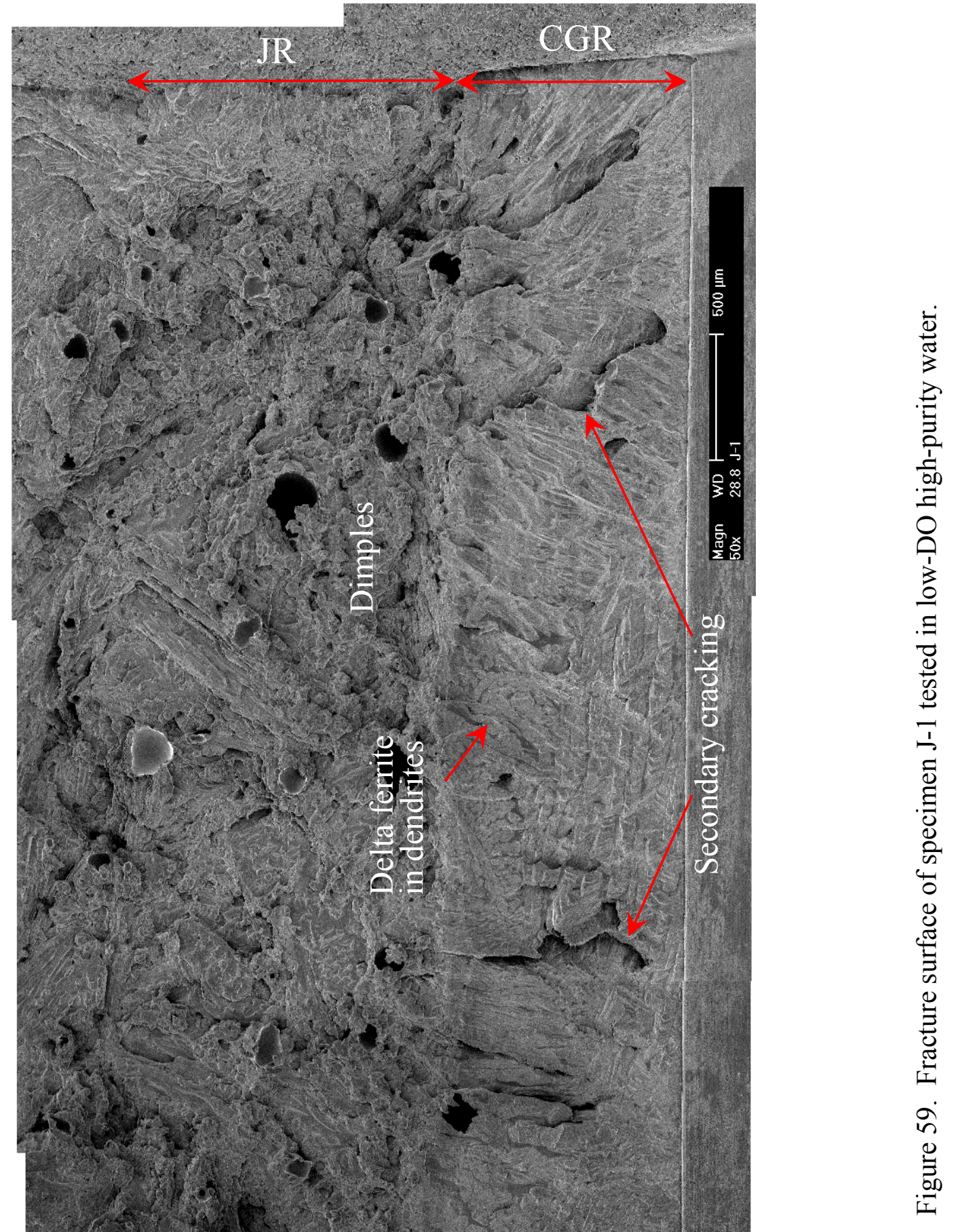




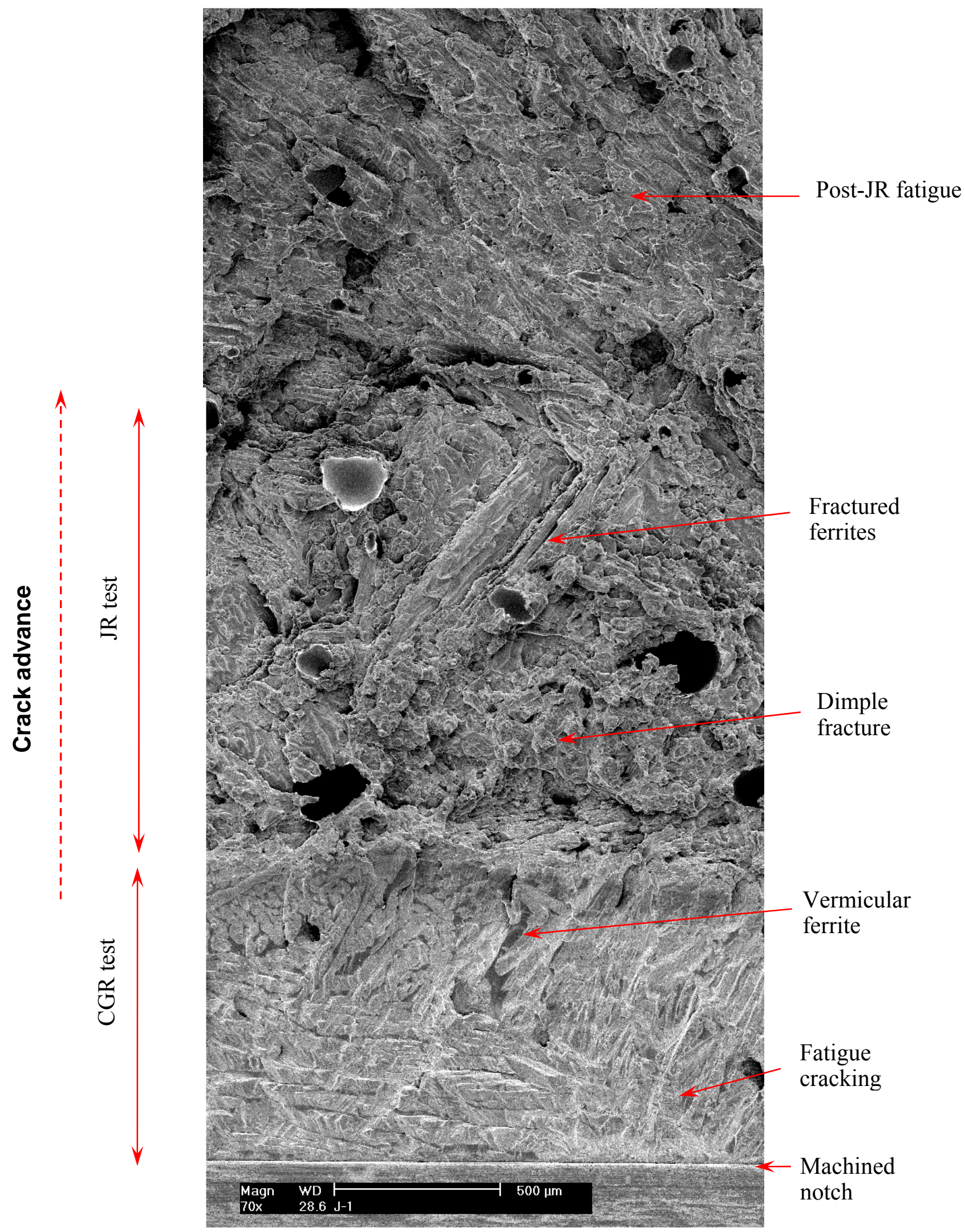

Figure 60. Fracture surface of specimen J-1 along the sample central line. 


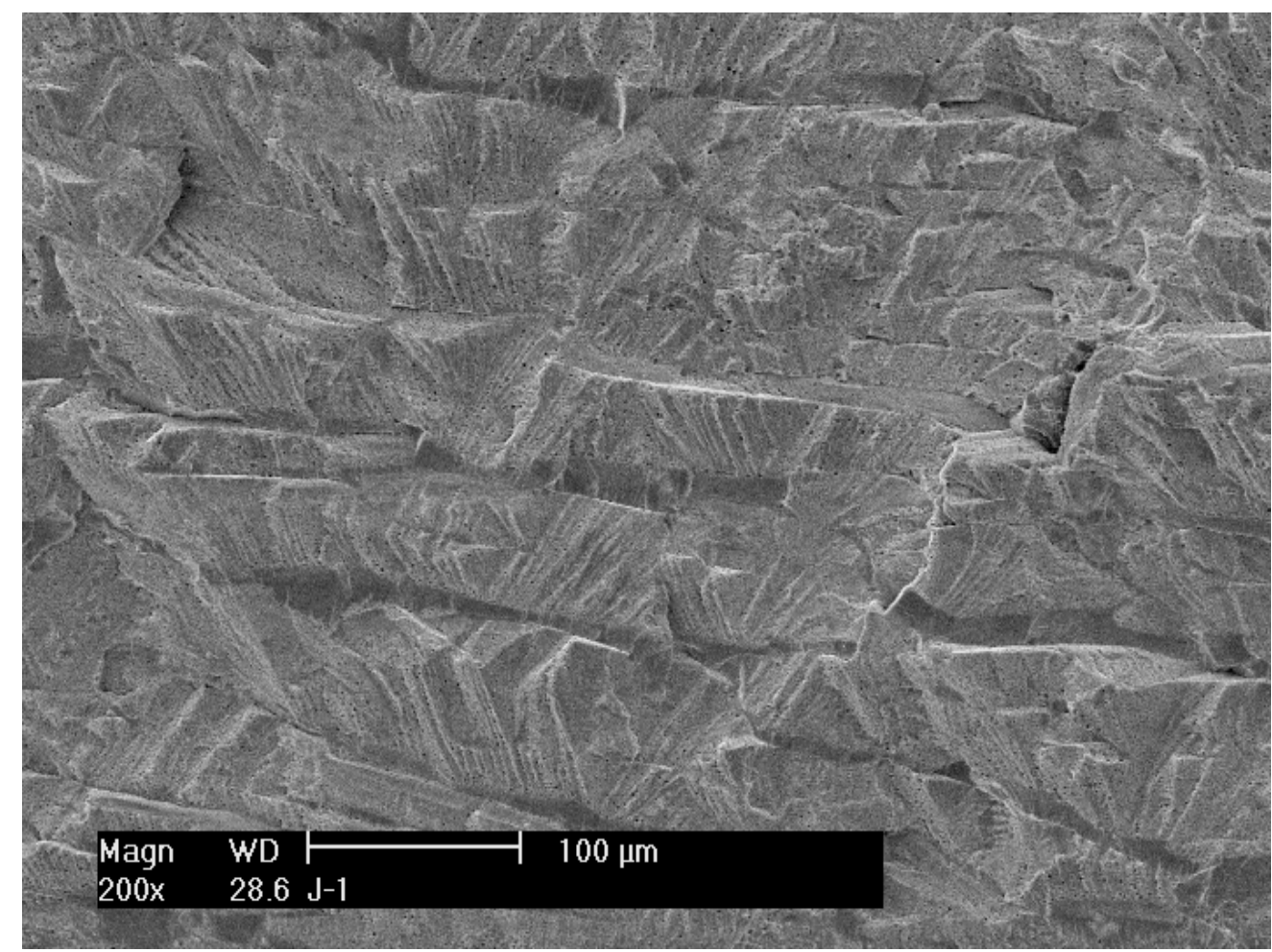

Figure 61. Precracking region of specimen J-1. Crack propagation from bottom to top.

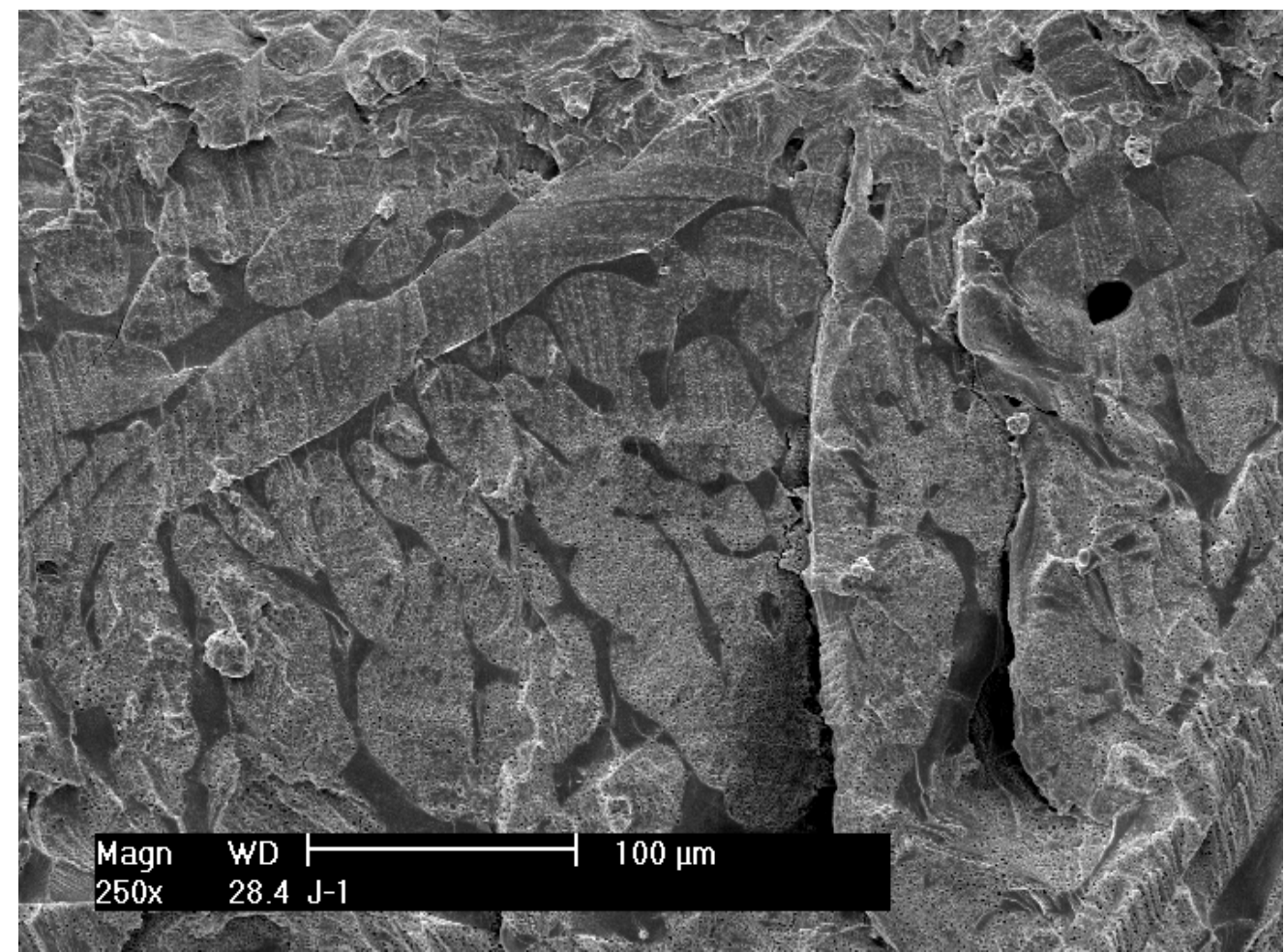

Figure 62. Ferrite microstructure at the end of CGR test of specimen J-1. Crack propagation from bottom to top. 


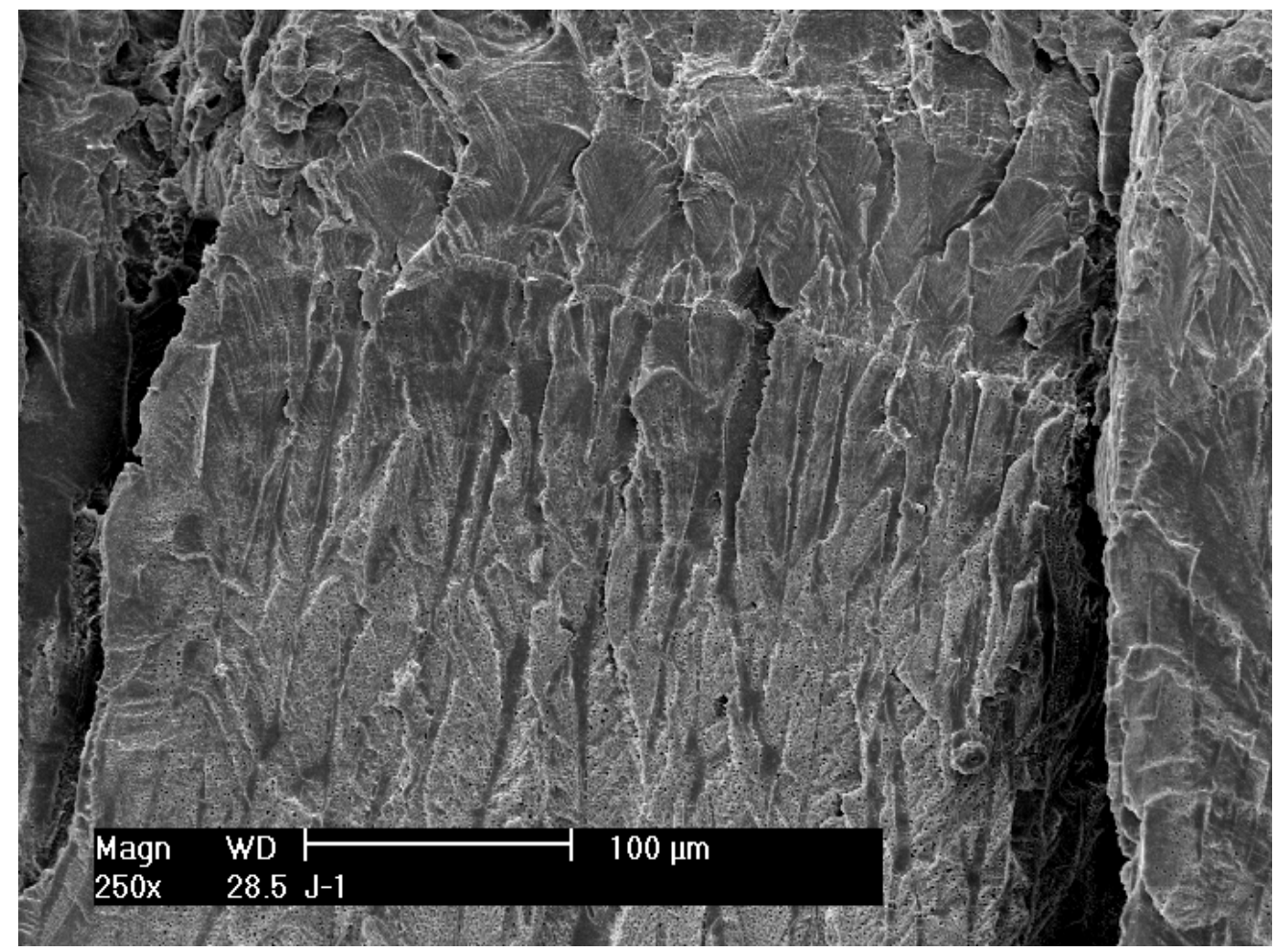

Figure 63. Cleavage fracture at the end of CGR test of specimen J-1. Crack propagation from bottom to top.

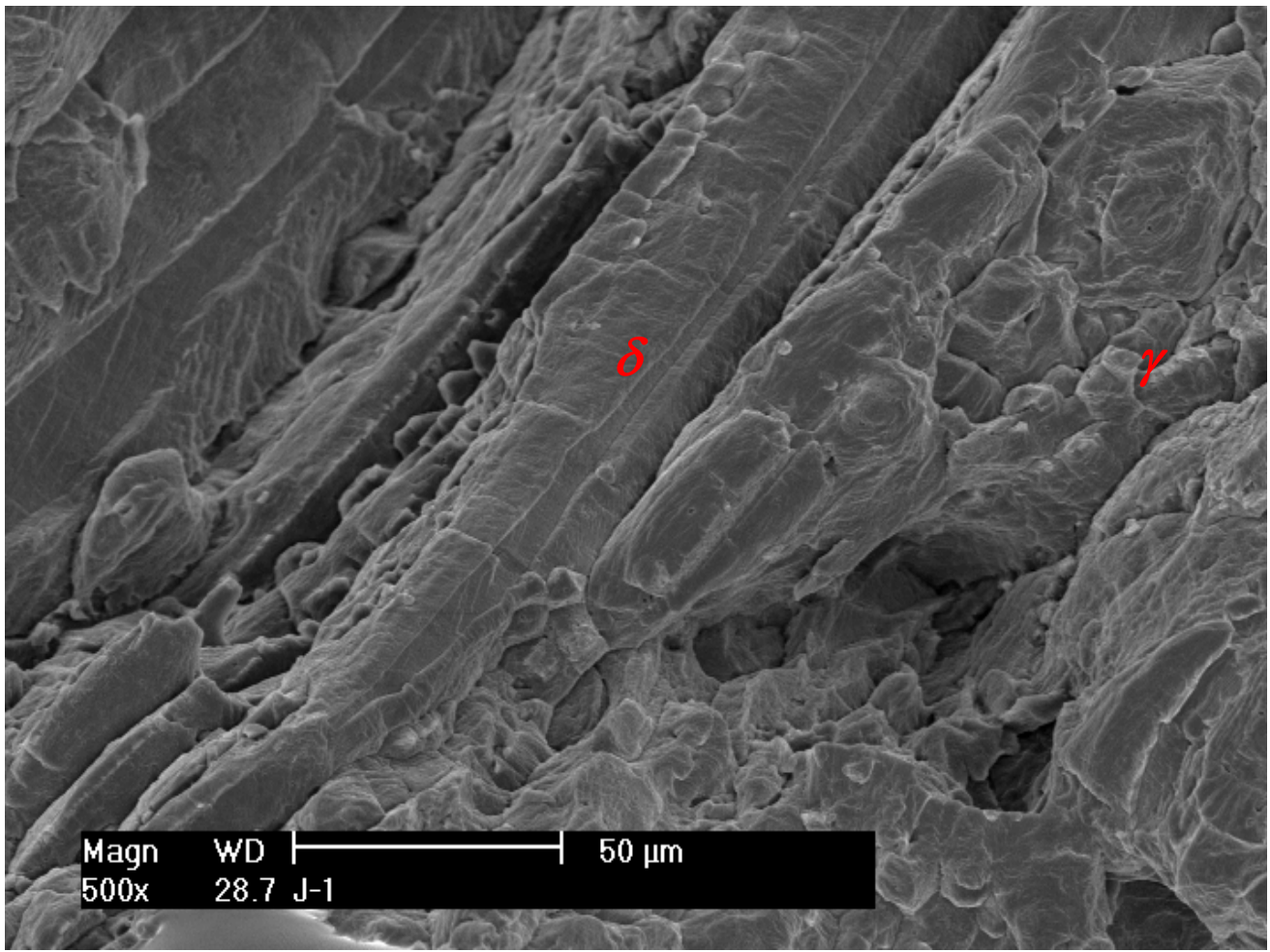

Figure 64. Fracture along ferrite at dendrite core in the JR test region of specimen J-1. Crack propagation from bottom to top. 
This page is intentionally left blank. 


\section{Discussion}

Seven 1/4T-CT specimens prepared from as-received and thermally aged CASS were irradiated to $0.08 \mathrm{dpa}$ in the Halden reactor. These samples were fabricated from CF-3, CF-8, and CF-8M CASS with high ferrite contents (more than $\sim 23 \%$ ). Three of the samples were thermally aged at $400^{\circ} \mathrm{C}$ for $10,000 \mathrm{hr}$ prior to irradiation. This thermal aging had been shown in a previous study 4,39 to yield a high degree of embrittlement in CASS materials. Crack growth rate tests were performed on these samples in either low-DO high-purity or PWR water environment at $320^{\circ} \mathrm{C}$. Cyclic and constant-load CGR tests of these materials were carried out at several stress intensity factors to assess the susceptibility to environmentally assisted cracking. Fracture toughness JR curve tests were also performed on these samples at $320^{\circ} \mathrm{C}$ with environmentally enhanced starter cracks. The measured SCC CGRs and JR results are summarized in Table 11. The parameters $C$ and $n$ are the fitting coefficients of the power-law relationship of $\mathrm{J}=\mathrm{C} \Delta \mathrm{a}^{\mathrm{n}}$. The $\mathrm{J}$ value at the $0.2-\mathrm{mm}$ offset line $\left(\mathrm{J}_{\mathrm{Q}}\right)$ is reported for each test.

The JR curve test results (shaded in yellow) on the irradiated specimens were compared with the results from a previous thermal aging study performed on unirradiated CASS materials (shaded in blue) in Table 11.39 The unirradiated CASS specimens were obtained from the same heats as the irradiated specimens and were also in unaged or thermally aged conditions $\left(400^{\circ} \mathrm{C}\right.$ for 10,000 hr). The unirradiated specimens were 1T-CT samples, larger than the irradiated specimens (1/4T-CT), and were tested in an air atmosphere at $290^{\circ} \mathrm{C}$. No crack growth rate tests were carried out on the unirradiated specimens. Experimental details of the unirradiated tests can be found in references $[22,39]$.

\subsection{Cyclic Crack Growth Rates}

Cyclic CGR data obtained from the unaged and aged CASS specimens were analyzed based on a superposition model previously developed by Shack and Kassner. ${ }^{38}$ By assuming that the environmental contribution to cyclic CGR is related to fatigue crack growth rate in air, Shack and Kassner determined the corrosion fatigue curves of unirradiated wrought and CASS SSs in high-purity water containing $0.2 \mathrm{ppm}$ and $8 \mathrm{ppm}$ DO. Using the corrosion fatigue curve of 0.2 ppm DO as a reference, the best fit curves for each data set of the CASS specimens are compared. For the CF-3 specimens with 24\% ferrite (Fig. 65a), the three fitting curves (aged and unaged in PWR, and unaged in low-DO high-purity environment) are all bounded by the line of 0.2-ppm DO, suggesting that irradiation does not increase the cracking susceptibility of CF-3 at this dose level. The relatively low environmental enhancement in the CF-3 can be attributed to the beneficial effect of ferrite in CASS. Several authors have reported a better SCC resistance for CASS than wrought SSs in aqueous environments. 15,16

Similar to the CF-3, the best fit curves of both unaged and thermally aged CF- 8 in the current study are also below the bounding line (Fig. 65b). This suggests that the difference in carbon content does not have a significant impact on corrosion fatigue behavior at $0.08 \mathrm{dpa}$ and in lowDO high-purity or PWR water. For the CF-8M however, the fitting curves are slightly higher than the corrosion fatigue curve as shown in Fig. 65c. Obviously, the CF-8M samples are more susceptible to environmentally assisted cracking under the current test condition. Figure 66 shows the fitting coefficients for each data set obtained in the current study. While the 
coefficients for CF-3 and CF-8 are similar, the values for CF-8M are much higher. Based on the current data, the corrosion fatigue growth rate of $\mathrm{CF}-8 \mathrm{M}$ could be a factor of two to three higher than that of CF-3 and CF-8.

Table 11. CGR and JR curve test results at $320^{\circ} \mathrm{C}$ for 0.08 -dpa CASS specimens with high ferrite contents $(>23 \%)$.

\begin{tabular}{|c|c|c|c|c|c|c|c|}
\hline \multirow[b]{2}{*}{ Material $^{\mathrm{a}}$} & \multirow{2}{*}{$\begin{array}{l}\text { Sample } \\
\text { ID. }\end{array}$} & \multirow{2}{*}{$\begin{array}{l}\text { Test } \\
\text { Env. }\end{array}$} & \multicolumn{2}{|c|}{ SCC CGR ${ }^{b}$} & \multicolumn{3}{|c|}{ J-irr.c } \\
\hline & & & $\begin{array}{c}\mathbf{K} \\
\left(\mathrm{MPa} \mathrm{m}^{1 / 2}\right)\end{array}$ & $\begin{array}{l}\text { CGR } \\
(\mathrm{m} / \mathrm{s})\end{array}$ & C & $\mathbf{n}$ & $\begin{array}{c}\mathbf{J} \mathrm{Q} \\
\left(\mathrm{kJ} / \mathrm{m}^{2}\right)\end{array}$ \\
\hline $\begin{array}{l}\text { CF-3, 24\% ferrite, } \\
\text { Ht. 69, unaged }\end{array}$ & A-1 & PWR & 23.9 & $4.8 \mathrm{E}-11$ & - & - & - \\
\hline $\begin{array}{l}\text { CF-3, 24\% ferrite, } \\
\text { Ht. 69, unaged }\end{array}$ & A-2 & $\begin{array}{l}\text { Low-DO } \\
\text { high-purity }\end{array}$ & $\begin{array}{c}17.6 \\
19.6 \\
19.8 \text { (w/o PPU) } \\
19.8 \\
\end{array}$ & $\begin{array}{l}2.3 \mathrm{E}-11 \\
4.9 \mathrm{E}-11 \\
4.9 \mathrm{E}-12 \\
4.3 \mathrm{E}-11 \\
\end{array}$ & $\begin{array}{c}430 \\
- \\
- \\
- \\
\end{array}$ & $\begin{array}{c}0.64 \\
- \\
- \\
- \\
\end{array}$ & $\begin{array}{c}204 \\
- \\
- \\
- \\
\end{array}$ \\
\hline $\begin{array}{l}\text { CF-3, 24\% ferrite, } \\
\text { Ht. 69, aged }\end{array}$ & B-1 & PWR & 22.1 & $2.8 \mathrm{E}-11$ & 362 & 0.85 & 116 \\
\hline $\begin{array}{l}\text { CF- } 8,23 \% \text { ferrite, } \\
\text { Ht. } 68 \text {, unaged }\end{array}$ & E-1 & $\begin{array}{l}\text { Low-DO } \\
\text { high-purity }\end{array}$ & $\begin{array}{l}14.9 \\
16.8\end{array}$ & $\begin{array}{l}1.8 \mathrm{E}-11 \\
2.7 \mathrm{E}-11\end{array}$ & $\begin{array}{c}359 \\
-\end{array}$ & $\begin{array}{c}0.57 \\
-\end{array}$ & $\begin{array}{c}183 \\
-\end{array}$ \\
\hline $\begin{array}{l}\text { CF-8, 23\% ferrite, } \\
\text { Ht. 68, aged }\end{array}$ & F-1 & $\begin{array}{l}\text { Low-DO } \\
\text { high-purity }\end{array}$ & 16.0 & $2.7 \mathrm{E}-11$ & 372 & 0.62 & 171 \\
\hline $\begin{array}{l}\text { CF-8M, 28\% ferrite, } \\
\text { Ht. 75, unaged }\end{array}$ & I-1 & $\begin{array}{l}\text { Low-DO } \\
\text { high-purity }\end{array}$ & 17.9 & $1.9 \mathrm{E}-11$ & 336 & 0.66 & 145 \\
\hline $\begin{array}{l}\text { CF-8M, 28\% ferrite, } \\
\text { Ht. 75, aged }\end{array}$ & $\mathrm{J}-1$ & $\begin{array}{l}\text { Low-DO } \\
\text { high-purity }\end{array}$ & $\begin{array}{c}15.5 \\
15.6 \\
19.0 \\
18.9 \\
18.9 \text { (w/o PPU) }\end{array}$ & $\begin{array}{l}1.8 \mathrm{E}-11 \\
2.5 \mathrm{E}-11 \\
5.5 \mathrm{E}-11 \\
6.4 \mathrm{E}-11 \\
2.0 \mathrm{E}-12\end{array}$ & $\begin{array}{c}259 \\
- \\
- \\
- \\
-\end{array}$ & $\begin{array}{c}0.64 \\
- \\
- \\
- \\
-\end{array}$ & $\begin{array}{c}106 \\
- \\
- \\
- \\
-\end{array}$ \\
\hline
\end{tabular}

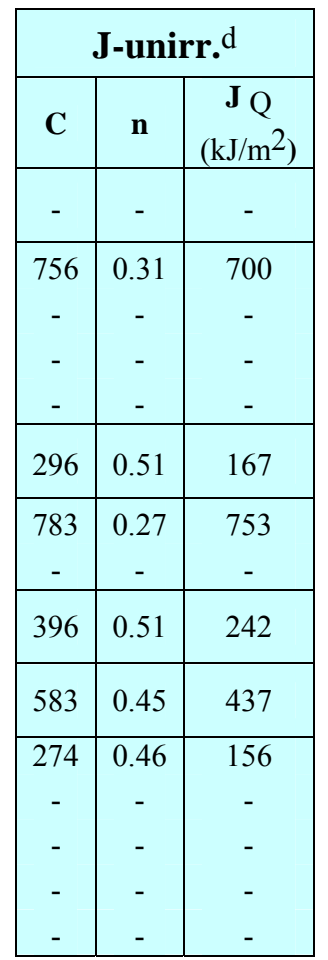

a Both unaged and aged materials were exposed to the irradiation temperature $\left(\sim 315^{\circ} \mathrm{C}\right)$ for approximately $4320 \mathrm{hr}$. The aging parameter P defined in reference [40] is 1.66, 1.82, and 2.07 for Material CF-3, CF-8, and CF-8M, respectively. Thus, the extent of embrittlement caused by the reactor temperature is negligible during the course of the irradiation.

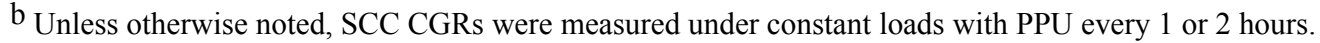

${ }^{\mathrm{c}}$ Results from $1 / 4 \mathrm{~T}-\mathrm{CT}$ specimens at $320^{\circ} \mathrm{C}$ in low-corrosion-potential environments.

d Previous results from 1T-CT specimens at $290^{\circ} \mathrm{C}$ in air atmosphere (NUREG/CR 4744, No.7).

As shown in Fig. 66, the fitting coefficients "A" (in $\mathrm{CGR}_{\mathrm{env}}=\mathrm{A} \cdot \mathrm{CGR}_{\mathrm{air}}{ }^{0.5}$ ) of thermally aged CASS are about 20\%-30\% lower than those of unaged CASS. This difference implies a lower cracking susceptibility for thermally aged than unaged CASS. Since the comparative tests were performed in an identical environment (in either PWR or low-DO high-purity water), the different corrosion fatigue responses might be attributable to thermal aging. However, given the large scatter in CGR data, the observed differences between thermally aged and unaged CASS may not be statistically significant. Nonetheless, the current study clearly shows that the corrosion fatigue behavior is similar between unaged and thermally aged CASS in lowcorrosion-potential environments. This observation contrasts with the finding of unirradiated CASS in high DO concentrations. The cyclic CGRs of thermally aged CASS were found to be one order of magnitude higher than those of unaged alloys in high-DO water $(>1 \mathrm{ppm}) .{ }^{38}$ The mechanism leading to similar CGRs between unaged and thermally aged CASS in low DO environments needs to be better understood. 

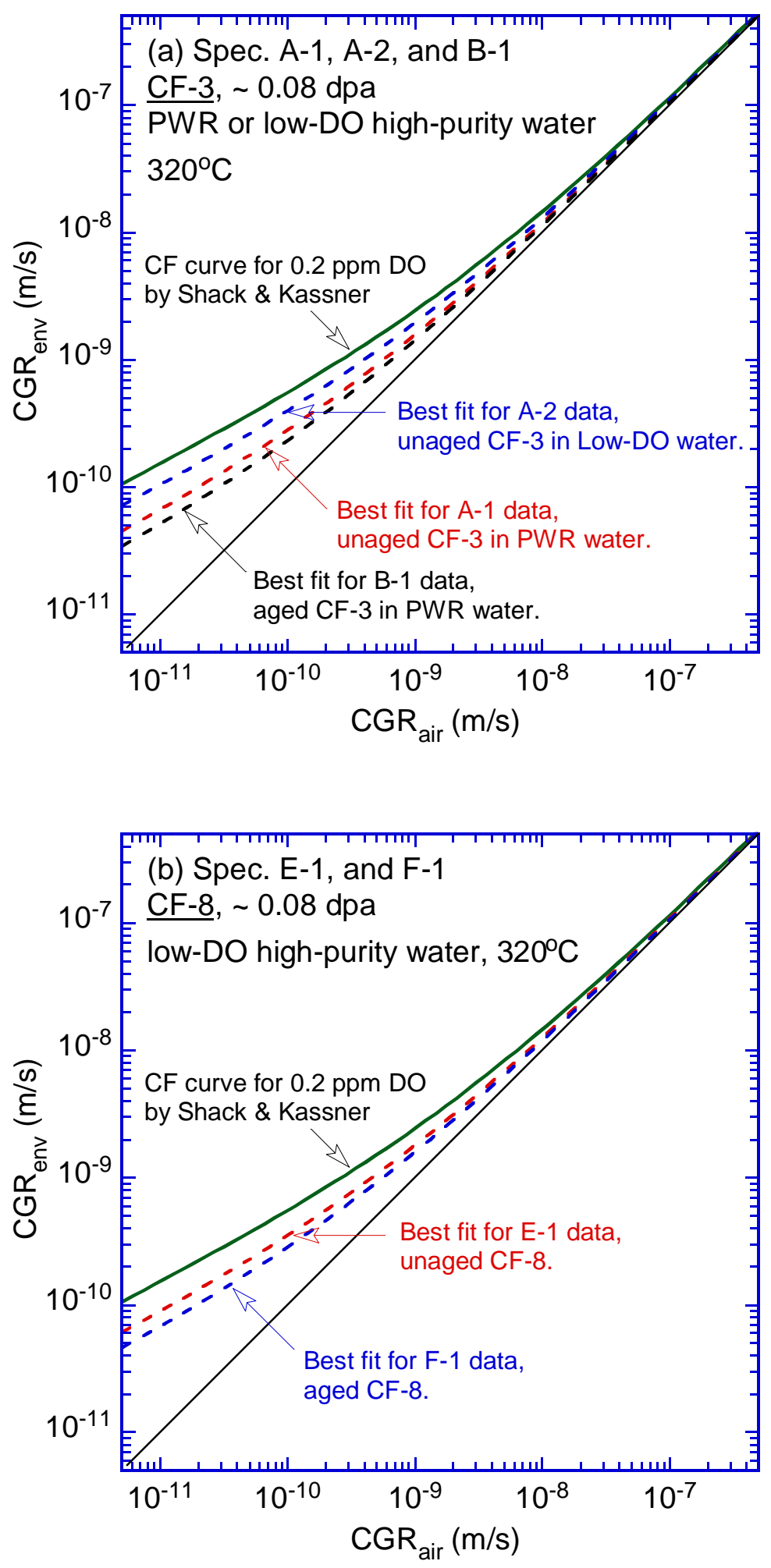

Figure 65. Best-fit curves of cyclic CGRs at 0.08-dpa dose: (a) unaged and aged CF-3, (b) unaged and aged CF-8, and (c) unaged and aged CF-8M. 


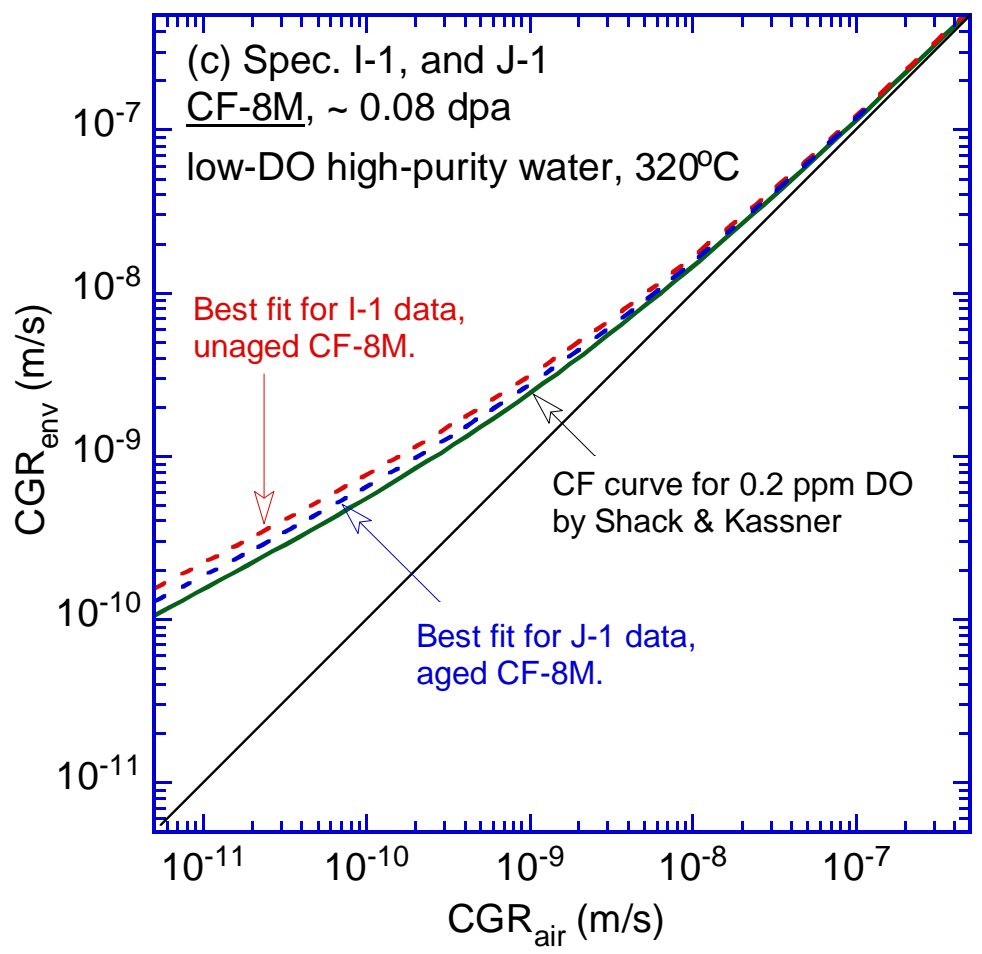

Figure 65. (Contd.)

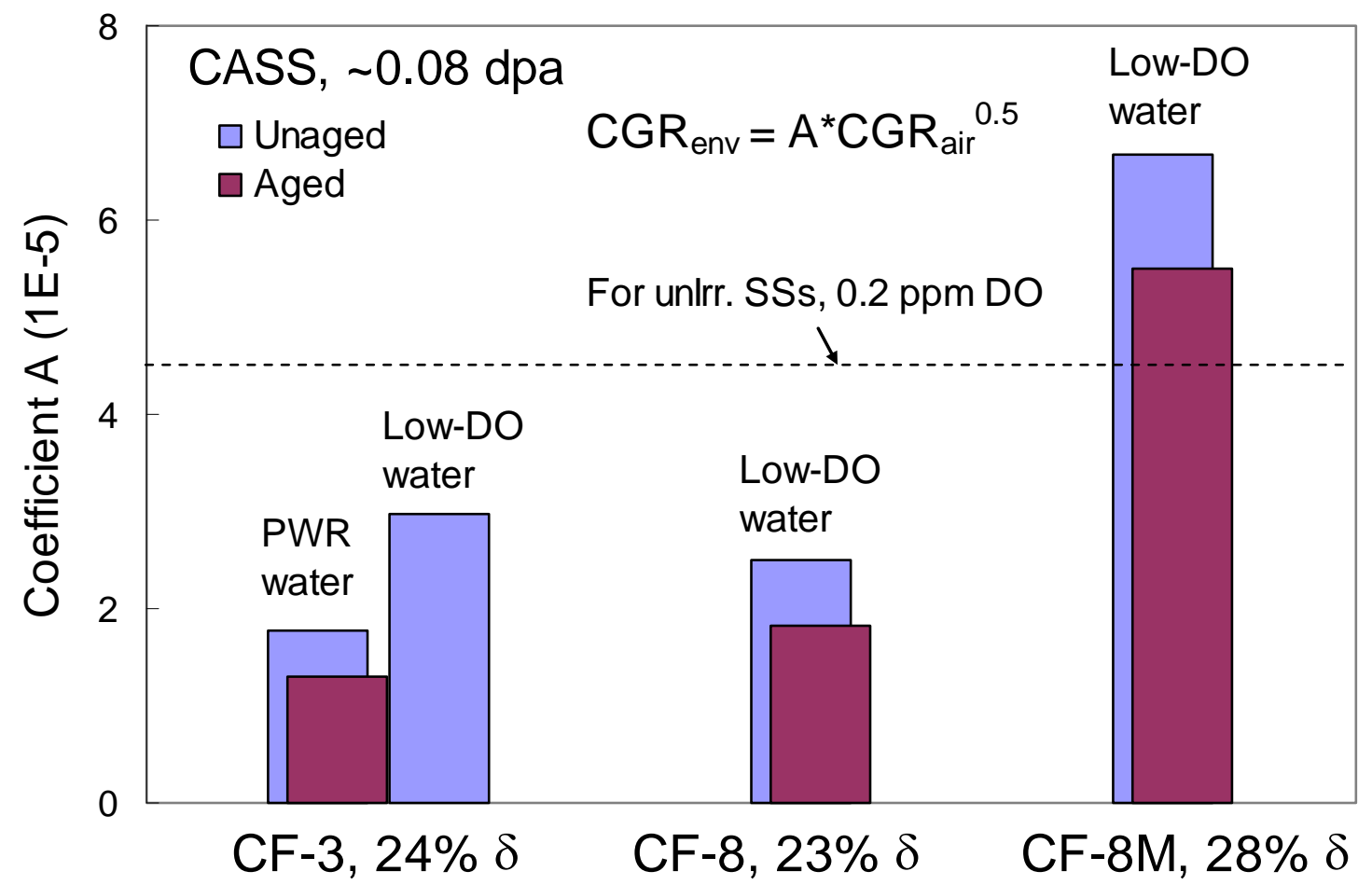

Figure 66. Fitting coefficient A for the corrosion fatigue superposition model. 


\subsection{Constant-load Crack Growth Rates}

All constant-load CGRs obtained with or without PPU are plotted in Fig. 67. The open symbols are unaged CASS, and the closed symbols are their thermally aged counterparts. All data points are well below the NUREG-0313 line, and moderate CGRs in the range of $10^{-11} \mathrm{~m} / \mathrm{s}$ are only obtained under loading conditions with PPU. Without PPU, the measured CGRs (the two square symbols in Fig. 67) are more than one order of magnitude lower. An accurate determination of such a low growth rate would require a much longer test time than possible in the current study. In general, the tested CASS specimens show good SCC resistance, and neutron irradiation up to 0.08 dpa does not appear to elevate their cracking susceptibility significantly in the PWR and low-DO high-purity water environments.

The unaged and thermally aged data sets, regardless of their grades and test conditions, are fitted to a power-law expression with an exponent of 2.16 (same as the NUREG-0313 curve). As shown in Fig. 67, the fitting curve of thermally aged CASS is just slightly higher $(<20 \%)$ than that of unaged CASS. However, given the large scatter of the data set and the inherent uncertainty in short CGR tests like these, this difference is statistically insignificant. Thus, thermal aging does not appear to affect the cracking susceptibility of the CASS specimens in the low-DO high-purity and PWR water. This lack of sensitivity to thermal aging history is consistent with that observed in cyclic CGR tests.

A low susceptibility to IASCC is expected for CASS owing to the beneficial effects of ferrite. It has been shown that unirradiated CASS samples are more resistant to SCC than wrought SSs in high-DO water. ${ }^{15,16}$ The superior SCC performance of the duplex microstructure may arise from the deformation behavior of the ferrite phase. Ferrite is more difficult to deform plastically compared with austenite under the same stress level. Using a nano-indentation measurement, Wang et al. ${ }^{42}$ showed that the hardness of ferrite phase is higher than that of austenite phase in CF-8. Furthermore, the austenite is also more noble than the ferrite in corrosion potential measurements of single phase alloys. By delaying the development of heavy plastic deformation in ferrite phase, a slip-dissolution mechanism could be hindered to some extent in a duplex microstructure. Our fractographic examinations support this hypothesis. As shown in the micrographs in the CGR test regions (e.g., Figs. 11, 18, 28, 35, 44, 45, 53, 61), little plastic deformation can be seen within the ferrite phase. In contrast, the surrounding austenite grains are often heavily deformed. If this mechanism is correct, the beneficial effect of ferrite could be diminished, in principle, by thermal aging or irradiation embrittlement. A deteriorated fracture resistance of ferrite grains would accelerate the development of plastic strain in the surrounding austenite phase. In fact, elevated SCC CGRs have been observed in a thermally aged CF-8M at $\sim 2.4$ dpa. 31 This observation suggests that the beneficial effect of a duplex microstructure may be eliminated or greatly reduced by neutron exposure to a sufficiently high fluence level. 


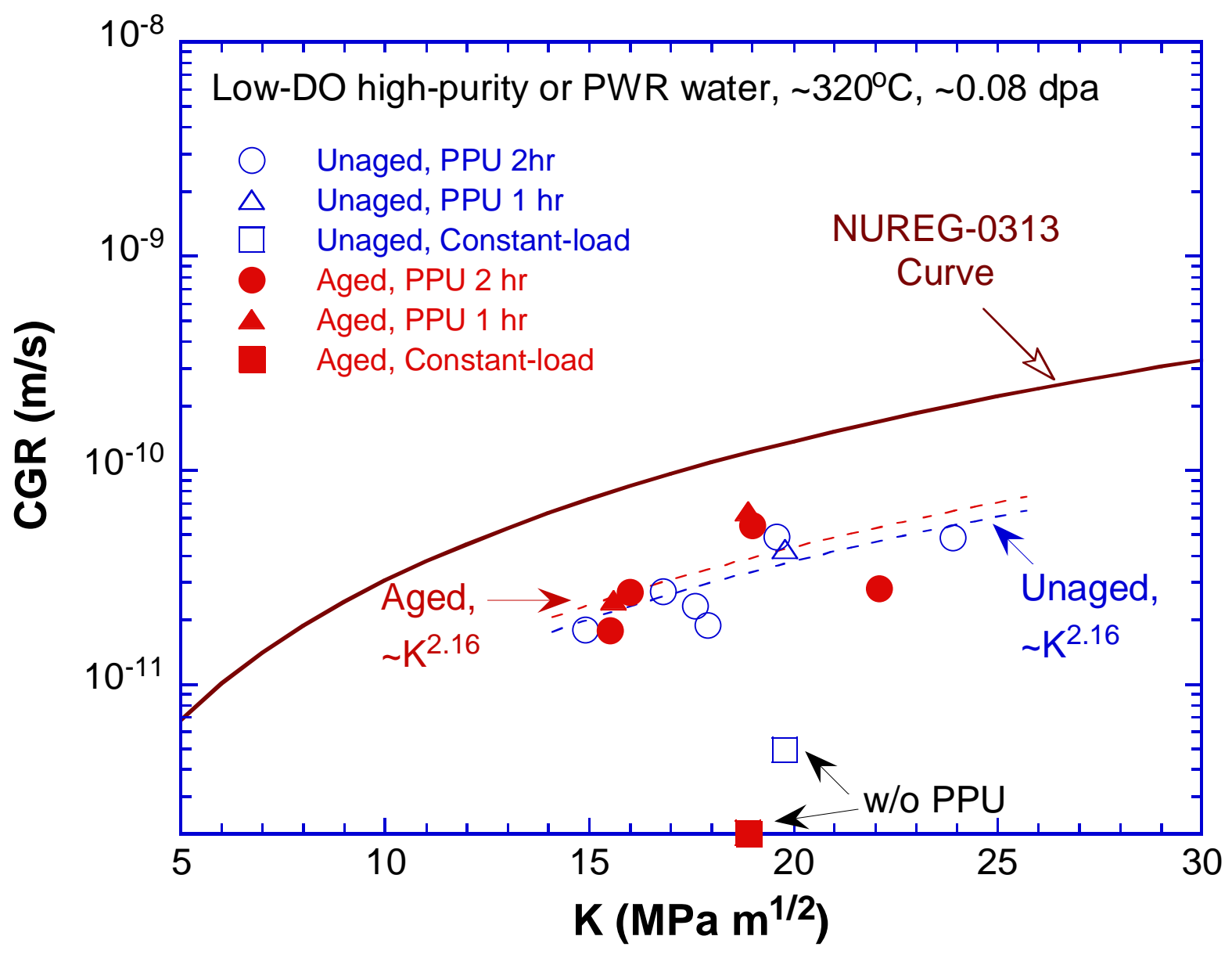

Figure 67. Constant-load CGRs of the low-dose CASS with more than $23 \%$ ferrite in low-DO high-purity and PWR water environments.

\subsection{Fracture Toughness}

Figure 68 shows all fracture toughness values ( $\mathrm{J}$ at $0.2 \mathrm{~mm}$ offset) obtained from the current study. The fracture toughness results of unirradiated specimens tested in air from Ref. [39] are also included. Neutron irradiation, even at such a low dose ( $0.08 \mathrm{dpa})$, has a significant impact on the fracture toughness of CASS. The extent of irradiation embrittlement is much greater for unaged than thermally aged specimens. After irradiation, the fracture toughness values of unaged CASS are less than one-third of their original unirradiated values. For thermally aged CASS, a 30\% reduction in fracture toughness is observed after irradiation. It is noted that the test environments of the irradiated and unirradiated tests are different, thus a potential effect of test environments on fracture toughness cannot be completely ruled out in this comparison. However, given the good SCC resistance observed in the CGR tests, it is unlikely that that test environments had a significant contribution to the loss of toughness in irradiated tests. Also, the fractographic examinations showed that both irradiated and unirradiated specimens had similar 
fracture morphology (ductile dimple) in JR test regions, suggesting an insignificant role of test environments in the irradiated JR curve tests. Thus, the differences between unirradiated and irradiated JR results are more likely due to the neutron irradiation than the test environments.

Because the deterioration in fracture toughness developed more rapidly with neutron irradiation in unaged CASS, the difference in fracture toughness between unaged and thermally aged specimens was reduced after irradiation. As shown in Fig. 68, the drastically different fracture toughness values between unaged and thermally aged specimens (blue bars) become somewhat comparable after irradiation (magenta bars). This change suggests a dominant role of neutron irradiation (compared to thermal aging) in promoting embrittlement in CASS. The rapidly developed irradiation effect in unaged materials may also explain the inconsistent observations between the current study and the previous work discussed in the last section. It has been shown that thermal aging can considerably decrease the cracking resistance of unirradiated CASS in high-DO high-purity water. ${ }^{38}$ However, in our study, both corrosion fatigue and SCC of irradiated CASS seem to be insensitive to thermal aging history (e.g., Figs. 66 and 67). There is no doubt that neutron irradiation had introduced detrimental effects in both unaged and thermally aged materials, but not necessarily at the same rate. It is possible that the unaged microstructure deteriorated more quickly than did the thermally aged microstructure at the current dose level. Consequently, the cracking behavior between the aged and unaged specimens became similar after irradiation.

While the irradiation damage seems to be a dominant factor for embrittlement, a combined effect of thermal aging and irradiation damage does reduce the fracture resistance of CASS further. As shown in Fig. 68, the fracture toughness values of thermally aged and irradiated specimens are approximately $30 \%$ lower than those of thermally aged specimens. This finding is the evidence points toward an interaction between thermal aging and irradiation embrittlement. More importantly, these results show that the kinetics of thermal aging embrittlement could be altered by irradiation, as could the saturation state (i.e., the lower bound of fracture toughness). This finding suggests that the conservatism assumed for thermal aging embrittlement needs to be examined closely under neutron irradiation. It is not clear however, how the ferrite content affects the extent of embrittlement. The CASS samples tested in this study all have high ferrite contents. If only ferrite is affected, the combined effect of thermal aging and irradiation damage should vary with the initial ferrite content. Additional tests on specimens with lower ferrite contents are needed to understand the precise role of ferrite in the combined effect. 


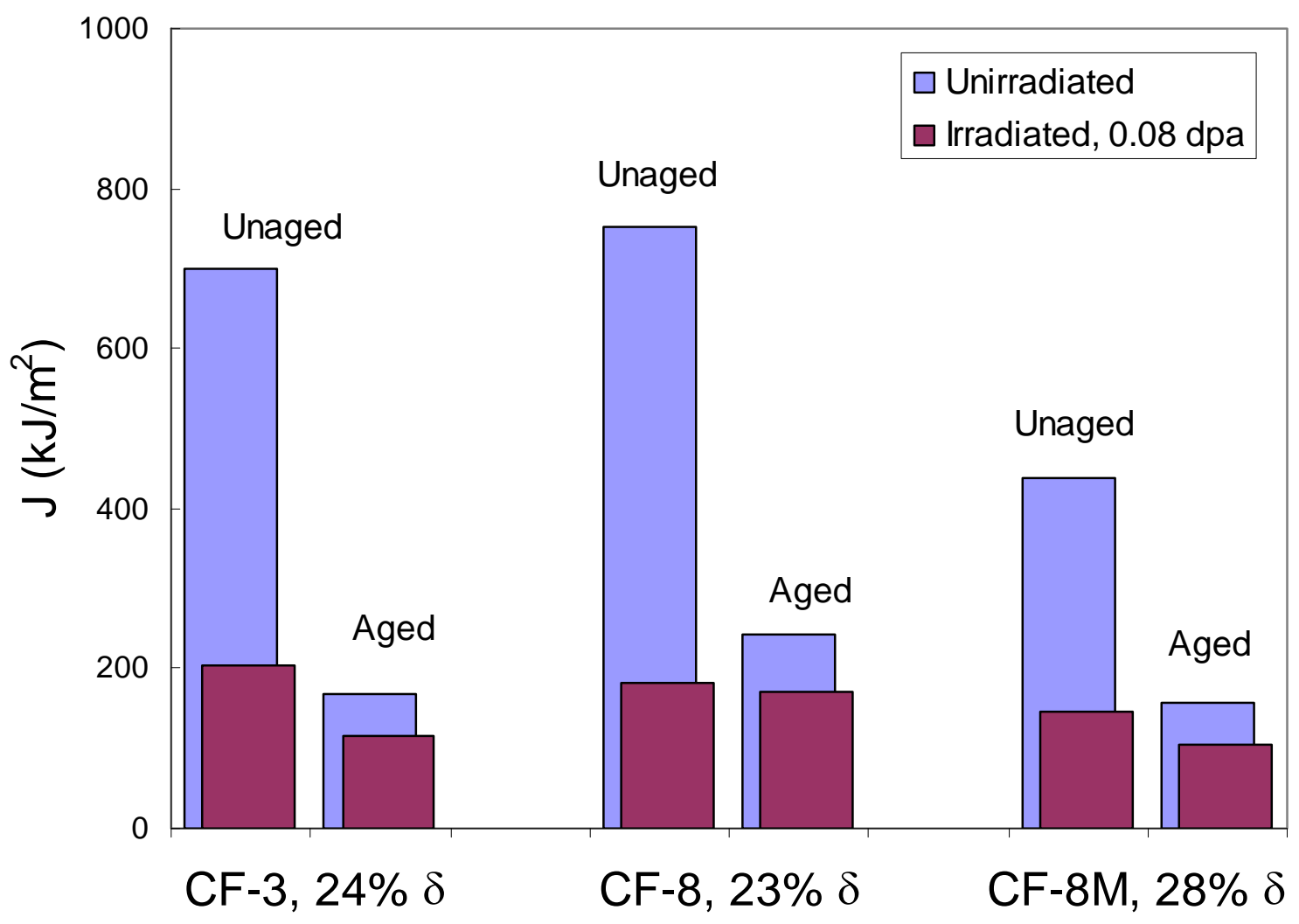

Figure 68. Fracture toughness values of unirradiated and irradiated CASS in unaged and aged conditions. (Note that the unirradiated results are from 1T-CT specimens at $290^{\circ} \mathrm{C}$ in an air atmosphere, and the irradiated results are from 1/4T-CT specimens at $320^{\circ} \mathrm{C}$ in water environments.)

The mechanisms of CASS thermal embrittlement are well understood. 17-20 A miscibility gap in the Fe-Cr phase diagram gives rise to a spinodal decomposition of two ferrite phases, a Fe-rich $\alpha$ phase and a Cr-rich $\alpha^{\prime}$ phase. The $\alpha^{\prime}$ phase has a slightly different lattice parameter from the matrix and, thus, strengthens the ferrite grains and causes the embrittlement. The redistribution of $\mathrm{Cr}$ within ferrite phase is accompanied by the rearrangement of other alloying elements, which can lead to additional nucleation and growth of precipitates within the ferrite phase or at the ferrite-austenite boundaries. Thus, carbides and Ni-rich G-phase are also found to be the main contributors to the thermal aging embrittlement of CASS. Under neutron irradiation, the kinetics of these embrittlement mechanisms may be affected. ${ }^{43}$ The natural miscibility gap could be widened, and new temperature-dependent wavelengths could be developed. While no irradiation microstructural work has been carried out in the current study, the mechanical test results suggest that an accelerated microstructural evolution occurs under neutron irradiation, and the initial microstructures of CASS may be a key factor for the evolution of irradiation microstructure. Detailed microstructural examinations of irradiation defects, precipitations, segregations, and phase stability in the ferrite phase and at austenite-ferrite boundaries would be helpful to explain the combined effect of thermal aging and irradiation embrittlement. 


\section{Summary}

Crack growth rate and fracture toughness JR curve tests have been conducted on CF-3, CF-8 and CF-8M CASS with high ferrite content $(>23 \%)$. The samples were irradiated in the Halden test reactor to a low dose of $0.08 \mathrm{dpa}$. Both as-received and thermally aged specimens were included to show the combined effect of thermal aging and irradiation embrittlement. The CGR tests were conducted in low-DO high-purity and PWR water environments at $320^{\circ} \mathrm{C}$. Following the CGR tests, fracture toughness JR curve tests were performed on the same samples in the test environments.

Cyclic CGRs and constant-load CGRs were obtained to evaluate the corrosion fatigue and SCC resistance of the CASS specimens. In cyclic CGR tests, environmentally enhanced cracking was more difficult to establish in the CASS specimens than in wrought SSs. In SCC CGR tests, only moderate CGRs in the range of $10^{-11} \mathrm{~m} / \mathrm{s}$ were recorded in the CASS specimens regardless of their thermal aging history. In general, the CASS materials showed good resistance to both corrosion fatigue and SCC at $0.08 \mathrm{dpa}$. Transgranular cleavage cracking was the dominant fracture mode during the CGR tests, and the ferrite phase was often deformed to a lesser extent than the surrounding austenite phase. This observation supports the hypothesis that the beneficial effect of ferrite arises in part from the high plastic deformation stress in ferrite phase.

A similar cracking behavior was observed for irradiated specimens between thermally aged and unaged CASS in low-DO high-purity water and simulated PWR environments. The lack of sensitivity to thermal aging history could be a result of low corrosion potential used in the current study. It is also possible that accelerated degradation may have taken placed in the unaged CASS. At the current dose level, deteriorated cracking properties were developed more efficiently in the unaged than in the thermally aged specimens.

All CASS specimens tested in this study failed in a ductile dimple mode during the fracture toughness JR curve tests. Neutron irradiation had a significant impact on the fracture toughness of CASS. At $0.08 \mathrm{dpa}$, the fracture toughness values of unaged specimens were about one-third of their initial unirradiated values. An additional 30\% reduction in fracture toughness was also observed for thermally aged specimens after irradiation. The combined effect of thermal aging and irradiation damage can reduce the fracture resistance of CASS to a higher extent than any one of them can achieve alone. These results show that neutron irradiation can affect not only the kinetics of thermal aging embrittlement, but also the saturation state (i.e., lower bound values of fracture toughness). For this reason, the effects of neutron irradiation should be considered when the degree of thermal aging embrittlement is evaluated for CASS components. 
This page is intentionally left blank. 


\section{References}

1. U.S. NRC, "Expert Panel Report on Proactive Materials Degradation Assessment," NUREG/CR-6923, 2006.

2. Blair, M., and T. L. Steven, Steel Castings Handbook, Sixth Edition, Steel Founders' Society of America and ASM International, 1995.

3. ASTM International, "Standard Specification for Castings, Austenitic, for PressureContaining Parts," A351/A351M-10, Annual Book of ASTM Standards, 2012.

4. Chopra, O. K., and A. Sather, "Initial Assessment of the Mechanisms and Significance of Low-Temperature Embrittlement of Cast Stainless Steels in LWR Systems," NUREG/CR5385, ANL-89/17, 1990.

5. Mills, W. J., "Fracture Toughness of Type 304 and 316 Stainless Steels and Their Welds," International Materials Reviews, 4, No.2 (1997): 45.

6. Leger, M. T., "Predicting and Evaluating Ferrite Content in Austenitic Stainless Steel Castings," Stainless Steel Castings, ASTM STP 756 (1982): 105-125.

7. Aubrey, L. S., P. F. Wieser, W. J. Pollard, and E. A. Schoefer. "Ferrite Measurement and Control in Cast Duplex Stainless Steel," in Stainless Steel Castings, ASTM STP 756 (1982): 126-164.

8. Schaeffler, A. L., "Constitution Diagram for Stainless Steel Weld Metal," Metal Progress, 56, No 11 (1949): 680-680B.

9. Hull, F. C., "Delta Ferrite and Martensite Formation in Stainless Steels," Welding Journal, 52 (1973): 183.

10. Long, C. J., and W. T. DeLong, "Ferrite Content of Austenitic Stainless Steel Weld Metal," Welding Journal, 52 (1973): 281.

11. Olson, D. L., "Prediction of Austenitic Weld Metal Microstructure and Properties," Welding Journal, 64, No. 10 (1985): 281.

12. ASTM International, "Standard Practice for Steel Casting, Austenitic Alloy, Estimating Ferrite Content Thereof," A800/A800M-10, Annual Book of ASTM Standards, 2012.

13. Beck, F. H., E. A. Schoefer, J. W. Flowers, and M. G. Fontana, "New Cast High-Strength Alloy Grades by Structure Control," in Advances in the Technology of Stainless Steels and Related Alloys, ASTM STP 369, 1965.

14. Floreen, S., and H. W. Hayden, "The Influence of Austenite and Ferrite on the Mechanical Properties of Two-phase Stainless Steels Having Microduplex Structures," ASM Transactions Quarterly, 61, No.3 (1968): 489-499.

15. Beck, F. H., J. Juppenlatz, and P. F. Wieser, "Effects of Ferrite and Sensitization on Intergranular and Stress Corrosion Behavior of Cast Stainless Steels," in Stress Corrosion New Approaches, H. L. Craig, Jr., ed., ASTM STP 610, 1976.

16. Hughes, N. R., W. L. Clarke, and D. E. Delwiche, "Intergranular Stress-Corrosion Cracking Resistance of Austenitic Stainless Steel Castings," in Stainless Steel Castings, V. G. Behal and A. S. Melilli, eds., ASTM STP 756, 1982. 
17. Fisher, R. M, E. J. Dulis, and K. G. Carroll, "Identification of the Precipitate Accompanying 885F Embrittlement in Chromium Steels," Transactions of AIME 197, No. 5 (1953) 690-695.

18. Grobner, P. J., "The 885 F (475 C) Embrittlement of Ferritic Stainless Steels," Metallurgical and Materials Transactions B, 4, No. 1 (1973): 251-260.

19. Nichol, T. J., A. Datta, and G. Aggen, "Embrittlement of Ferritic Stainless Steels," Metallurgical and Materials Transactions A, 11, No. 4 (1980): 573-585.

20. Trautwein, A., and W. Gysel, "Influence of Long-time Aging of CF8 and CF8M Cast Steel at Temperatures Between 300 and $500^{\circ} \mathrm{C}$ on Impact Toughness and Structural Properties," in Stainless Steel Castings, ASTM STP 756 (1982): 165-189.

21. Andresen, P. L., F. P. Ford, K. Gott, R. L. Jones, P. M. Scott, T. Shoji, R. W. Staehle, and R. L. Tapping, "Expert Panel Report on Proactive Materials Degradation Assessment (PMDA),” NUREG/CR-6923, BNL-NUREG-77111-2006, 2007.

22. Chopra, O. K., and A. Sather, "Initial Assessment of the Mechanisms and Significance of Low-Temperature Embrittlement of Cast Stainless Steels in LWR Systems," NUREG/CR5385, ANL-89/17, 1990.

23. Hiser, A. L., "Tensile and J-R Curve Characterization of Thermally Aged Cast Stainless Steels," NUREG/CR-5024, MEA-2229, 1988.

24. Solomon, H. D., and T. M. Devine, "Influence of Microstructure on the Mechanical Properties and Localized Corrosion of a Duplex Stainless Steel,” ASTM STP 672 (1979): $430-461$.

25. Chung, H. M., and O. K. Chopra, "Kinetics and Mechanism of Thermal Aging Embrittlement of Duplex Stainless Steels," Proc. 3rd Intl. Symp. on Environmental Degradation of Materials in Nuclear Power Systems - Water Reactors, Metallurgical Society, 1987.

26. Chung, H. M., and T. R. Leax, "Embrittlement of Laboratory and Reactor Aged CF3, CF8, and CF8M Duplex Stainless Steels," Materials Science and Technology, 6, No. 3 (1990): 249-262.

27. Leax, T. R., S. S. Brenner, and J. A. Spitznagel, "Atom Probe Examination of Thermally Aged CF8M Cast Stainless Steel," Metallurgical and Materials Transactions A, 23, No. 10 (1992): 2725-2736.

28. Hamaoka, T., A. Nomoto, K. Nishida, K. Dohi, and N. Soneda, "Effects of Aging Temperature on G-phase Precipitation and Ferrite-Phase Decomposition in Duplex Stainless Steel," Philosophical Magazine, 92, No. 22 (2012) 2716-2732.

29. Averback, R. S., "Atomic Displacement Processes in Irradiated Metals," Journal Nuclear Materials, 216 (1994): 49.

30. Wollenberger, H., "Phase Transformations Under Irradiation," Journal Nuclear Materials, 216 (1994) 63. 
31. Chopra, O. K., and W. J. Shack, "Crack Growth Rates and Fracture Toughness of Irradiated Austenitic Stainless Steels in BWR Environments," NUREG/CR-6960, ANL06/58, 2008.

32. Mills, W. J., "Fracture Toughness of Irradiated Stainless Steel Alloys," Nuclear Technology, 82, No. 3 (1988): 290-303.

33. Karlsen, T. M., “ANL Fabrication Report of Irradiation Capsules,' OECD Halden Reactor Project, 2009.

34. Andresen, P. L., F. P. Ford, S. M. Murphy, and J. M. Perks, "State of Knowledge of Radiation Effects on Environmental Cracking in Light Water Reactor Core Materials," Proc. 4th Intl. Symp. on Environmental Degradation of Materials in Nuclear Power Systems -- Water Reactors, NACE, Houston, TX, pp. 1.83-1.121, 1990.

35. ASTM International, "Standard Test Method for Measurement of Fracture Toughness," E1802-08a, Annual Book of ASTM Standards, 2008.

36. Hazelton, W. S., and W. H. Koo, "Technical Report on Material Selection and Processing Guidelines for BWR Coolant Pressure Boundary Piping,” NUREG-0313, Rev. 2, 1988.

37. James, L. A. and D. P. Jones, "Fatigue Crack Growth Correlation for Austenitic Stainless Steels in Air," In Predictive Capabilities in Environmentally Assisted Cracking, PVP Vol. 99, ASME, pp. 363-414, 1985.

38. Shack, W. J., and T. F. Kassner, "Review of Environmental Effects on Fatigue Crack Growth of Austenitic Stainless Steels," NUREG/CR-6176, 1994.

39. Chopra, O. K., "Long-Term Embrittlement of Cast Duplex Stainless Steels in LWR Systems," NUREG/CR-4744, ANL-93/11, 1993.

40. Chopra, O. K., "Estimation of Fracture Toughness of Cast Stainless Steels During Thermal Aging in LWR Systems,” NUREG/CR-4513, Rev. 1, ANL-93/22, 1994.

41. Kassner, T. F., W. E. Ruther, and W. K. Soppet, "Mitigation of Stress Corrosion Cracking of AISI 304 Stainless Steel by Organic Species at Low Concentrations in Oxygenated Water," Corrosion 90 (1990): 489.

42. Wang, Z., F. Xue, J. Jiang, W. Ti, and W. Yu, "Experimental Evaluation of Temper Aging Embrittlement of Cast Austenitic Stainless Steel from PWR," Engineering Failure Analysis, 18 (2011): 403.

43. Garner, F. A., J. M. McCathy, K. C., Russell, and J. J. Hoyt, "Spinodal-like Decomposition of Fe-35Ni and Fe-Cr-35Ni Alloys during Irradiation and Thermal Aging," Journal Nuclear Materials, 205 (1993): 411. 


\section{Argonne}

Nuclear Engineering Division

Argonne National Laboratory

9700 South Case Avenue

Argonne, IL 60439

www.anl.gov 